\title{
'O LI'ILI'I ' $O$ LISEGA 'O LE FANAA' \\ Missionary and government influences on Samoan language change 1906-2014
}

Sadat Petelo Tuimuaiava

\author{
A thesis \\ Submitted to Victoria University of Wellington \\ in fulfillment of the requirements for the degree of \\ Doctor of Philosophy
}

Victoria University of Wellington

2020 


\section{ABSTRACT}

The arrival of the missionaries and foreign administrations ${ }^{1}$ in Sāmoa in 1830 and 1900, respectively, initiated a surge in the integration of foreign types (words) in the gagana Sāmoa (Samoan language). To date, research regarding changes to the gagana as a result of this contact has largely been observational (Pratt 1862, Cain 1986, Mosel and Hovdhaugen 1992, Allardice 2000, Lāmeta 2005, Tamasese 2005, Ma'ia'i 2010, Macpherson 2010, Kruse-Vā‘ai 2011, Ma'ilo 2016). While these studies are valuable, this study seeks to enhance current research through a systematic and empirical examination of changes to the gagana. As a result, this research is guided by three research questions:

1. What can a diachronic analysis of the lexicons of lāuga fa 'amatai and lāuga fa'alelotu tell us about language change in gagana Sāmoa since the arrival of the missionaries in 1830 ?

2. What has been the nature of language contact between läuga fa 'amatai and läuga fa'alelotu?

3. To what extent can changes in the gagana Sāmoa be attributed to social change?

Fa'afaletui and Corpus methodologies were used. The Fa'afaletui methodology is a Samoan methodology used to obtain the perceptions of insider informants about changes to the gagana. The corpus methodology was used as an empirical method to also analyse changes to the gagana.

To investigate changes to the gagana over time and at specific periods, four indicator years were used for the corpus to represent a significant period of social contact in Sāmoa. These are: 1906, 1944, 1977 and 2014. From the corpus of Sulu Sāmoa and Sāvali texts from 1906-2014, a combined word list consisting of 1,475 foreign types was identified.

The perceptions of insider informants point to the profound influence of the missions on the gagana, and how the written word, particularly the translation of the Bible, aided religious conversion and formalised new ideologies and vocabularies. Their perceptions also point to the considerable influence of government on the gagana in the areas of government divisions and

\footnotetext{
${ }^{1}$ Foreign administrations here refer to the formal establishment of the German and New Zealand administrations in 1900 and 1914 respectively. It does not include consulates that were in place in Sāmoa prior to 1900.
} 
education. In addition, the lack of gagana standardisation and the increase in Samoan population movement and growth in metropolitan centres have intensified language change.

The fa 'afaletui sessions were enhanced by the corpus findings which indicate that over time, the evolution of foreign words into the gagana was integrated using five different lexical constructions and demonstrate the Samoan language has changed considerably between 19062014.

The implementation of the fa 'afaletui and corpus methodologies meets the Pacific research aims of this research in that it values the use of both Pacific and non-Pacific methodologies for Pacific language research.

This research offers a platform for examining changes to gagana Sāmoa over time that draws on the perspectives of insider informants and data from newspaper texts. The examination is an in-depth discussion and overview of the influences of the mission Church and Westminster State on changes to the gagana and provides a holistic approach and appreciation of the correlations between language and the social environment. Finally, this research values the call by Teaiwa (2009) for more Pacific-related research that values and incorporates both Pacific and non-Pacific methodologies. 


\section{DEDICATION}

This thesis is dedicated to our late grandparents, my father's parents Tuimuai'ava Ioane and Asosa'asa'a To'iaivao Tuimuai'ava and my mother's parents Leatuāvao Matai'a Fa'alata and Tagisia Vaisigano Leatuāvao, whose gagana and fa 'amanuiaga we have inherited. I felt your spirits with me during this journey. 'O lā 'outou tautua ma alolofa 'i le nu'u, 'ekālesia, fa'afeagaiga 'o le nu'u, lea 'ua fua mai. E manatua pea 'outou 'i o mātou loto ma agaga.
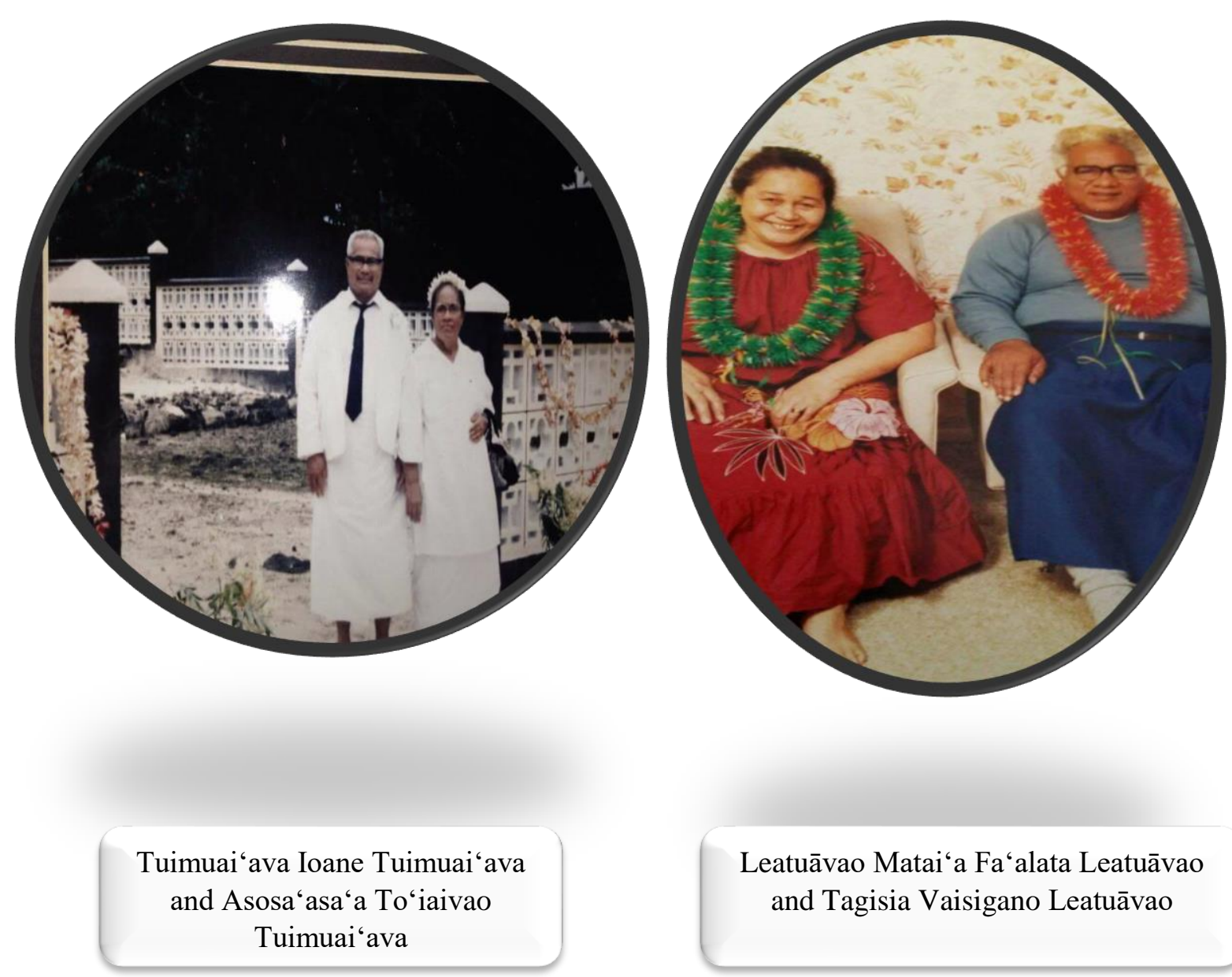

Leatuāvao Matai‘a Fa‘alata Leatuāvao and Tagisia Vaisigano Leatuāvao 


\section{'O LA'U FA'AFETAI ACKNOWLEDGEMENTS}

“Aua ne 'i iā te'i matou, le Ali 'i e, 'aua ne 'i iā te'i matou, a ia tu 'uina atu le vi 'iga i lou Suafa, 'ona 'o lou alofa ma lou fa 'amaoni." (Salamo 115: 1).

First and foremost I would like to give all praise and thanks to God for His guidance and endless love. Tamā, fa'afetai 'i lou alofa. 'Ia vi'ia lou Suafa e lē aunoa.

I would like to thank Professor Dr. John Macalister and Associate Professor Dr. Tamasa'ilau Suaali'i-Sāuni for their knowledge and patience throughout this journey. God Bless you both abundantly.

Thank you to my Va 'aomanū 'āiga for your love and support. To our dear colleague Associate Professor Teresia Teaiwa who passed away last year, thank you for all your love and support throughout the years. It has never been the same without you. We miss you!

Thank you to our church congregation, the Congregational Christian Church of American Sāmoa (EFKAS) in Wainuiomata for your never-ending prayers and support. Fa'afetai le nofo tatalo. Le susū 'i lau Susūga 'i le Toeā'ina ma le faletua, le Susū 'i Susūga 'i A'oa'o Fesoasoani ma 'outou faletua, le Nofoase'etasi 'o le Matāgaluega, lau Afioga 'i le Ti'ākono Toeā'ina Pātea Misa Pātea ma lou faletua Veta Patea, Afioga 'i Ti'ākono ma 'outou faletua, Ti'ākono Tinā ma o 'outou ali'i, le nofoamatāfale 'o le 'Ekālesia, mātua tausi 'o si o tātou 'Ekālesia, se'ia o'o 'i lalovaoa, a'o le pa 'ia lava fo'i lea 'o Sāmoa 'ua potopoto, mai lava le Tai Samasama nai Saua se'ia pa'ia le Tai 'Ula'ula na tauilo ai mālō. Fa'afetai mo talosaga, fa'afetai mo le tapuā'iga.

Le tapuā'iga a le Matāgaluega EFKAS a Niu Sila ma 'Ausetalia, lau Susūga 'i le Toeā'ina Māfutaga Fa'aleaogā ma lou faletua La'ia Fa'alēaogā. Le Pulega EFKAS 'i Uelegitone, lau Susūga 'i le Fa'afeagaiga Ieremia ma Lagi Allan, le nofo a fa'afeagaiga ma 'outou faletua, fa'afetai le nofo tatalo.

Fa'afetai fo'i 'i le tapuā'iga a le Māfutaga a Faife'au So'ofa'atasi a Uelegitone, lau Susūga 'i le Ta'ita'ifono ma le laulauafono, Susū 'o Toeā'i'ina, Afioga 'i Sea ma Pātele, susūga 'i fa'afeagaiga, fa'afetai tele 'o lā 'outou pule lea.

'O 'upu a le atunu'u, 'o le tagata ma lona gafa, 'o le tagata fo'i ma lona fa'asinomaga. 'Avea lenei avanoa e momoli ai la'u fa 'afetai 'i le tapuā'iga a fa'afeagaiga taulagi 'uma 'o Sāfa'ato'a 
ma Faleāse'elā. Lau Susūga 'i le Toeā'ina Nomeneta ma Taua Simanu, lau Susūga 'i le Fa'afeagaiga I'aeva ma Fatu'olo Amitai, lau Susūga 'i le Fa 'afeagaiga Mōtuga ma Sioi Matagi (Tuimuaiava), fa'afeagaiga ma o lātou faletua, fa'apea la tātou 'Ekālesia EFKS ‘i Sāfa'ato'aTai ma le 'Ekālesia Katoliko ‘i Faleāse'elā-Tai. Fa'afetai mo talosaga mōlia. Mālō le tapua'i.

Momoli la'u fa'afetai 'i le tapuā'iga a o'u nu'u, le Afifio 'o le 'Āiga Sātuala, le Uso ma le 'Ailaoa, le Susū 'o Lavasi'iuta ma Lavasi 'itai, le Tafa'i Pa'ia, lau Tōfā Tuimuai'ava, le mamalu lava lea 'iā te 'oe Tuisāvailu'u ma lou Nofoitū'āiga. Fa'apea le Taulagi ma Matua 'o Sātuala, To'oto'o ‘o Ma'auga ma le mamalu 'i le Faleā'ana. Le tapuā'iga 'i le Tama 'Āiga ma le Falefitu 'o le 'Āiga Taua'ana ma 'upu 'iā te 'oe Falelātai, le tapuā'iga a le 'Āiga Sā Gauifaleai ma Tuisāmau, fa'apea Sālevalasi, le Afio 'o le Sa'o Fa'apito ma le Ulua'i Sa'o ma le mamalu 'i le Faleātua. Fa'afetai le tatalo!

'O le talitonuga a Sāmoa anamuā, e mou le tino, 'ae feso'ota'i pea mauli ma mātua 'ua fai 'i lagi le folauga. E manatua ma le alofa mātua a o mātou mātua, Tuimuaiava Ioane Tuimuaiava ma Asosa'asa'a To'iaivao Tuimuaiava, Leatuāvao Fa'alata Matai'a Leatuāvao ma Tagisia Vaisigano Leatuāvao, matou te alolofa tele mo 'outou.

Le tapuā'iga a nai o'u 'āiga, lau Tofā i le Tafa'ipa'ia Tuimuaiava Alofipō Toso ma Tai Tuimuaiava; Leatuāvao Lupematasila Masoe Atonio and Taua Leatuāvao, Leatuāvao Vito ma Silafa'i Leatuāvao; Le’ausalilō Petelo ma Maima, Taualumaga Kitiona Tuimuaiava ma Finao Tuimuaiava, Lilomaiava Iulio ma Fa'asalafa Pati; my late uncle Le'ausalilō Ameto ma Alofa; Le'ausalilō Tasi ma Asofa, Tausaga Leatuāvao ma Leota Mū, Molia and Jeff Tuimuaiava; Tāvita ma Selau Lologa; Aneta ma Eikiumeni Fau'olo, 'Auala Enele ma Sitoga Tuimuaiava, nai o'u tausoga fa'apea o'u uso ma tuafäfine, Semisi ma 'Ula, Matai'a Susana, Peter ma le fānau, Le‘ausālilō Kasi, Azaria ma le fānau, Tea ma Fatiala Tiso Sa'olele ma baby Nu'ulua, Sānita ma Fa'aeteete Faituā ma baby Pelenatete, ma Asosa 'asa 'a Tuimuaiava. E manatua pea le tuafāfine 'o le matou tua'ā, Fa'asalafa ma Lei'ataua Tokuma, sā mātou nofo ā'o'oga ai 'i Sogi, Sāmoa. E manatua fo'i Finau Pa'usisi, Fofoa Tafa ma Silia Tuimuaiava Kuka, fa'amālō lava fa'afetai.

Mō nai o'u mātua, Toeā'ina Malaki Tuimua'i'ava ma Rosalili Tuimuaiava, fa'afetai mo mea 'uma. 'O talosaga, 'o fautuaga, 'o tupe ma lo lua taimi. Mālō le anapogi. Palē 'ua pale, titī e 'ua titi, 'ula e 'ua 'ula, seī e 'ua sei. 'O la'u fa'afetai fo'i 'i mātua 'o si o'u to'alua, lau Tōfā Sitama Uili ma Katie Chadwick, fa'afetai mo le tapuā'iga. Mālō le nofo tatalo. 


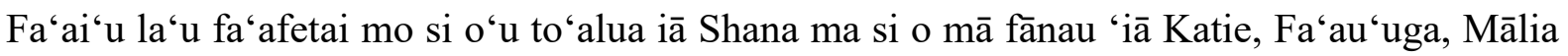
ma Malaki Tuimuaiava. Shan, fa'afetai tele lava mo mea 'uma. Mālō le tatalo, mālō le fa'atuatua, mālō le anapogi, mālō le 'onosa'i. Lea 'ua tau lau 'o le fa'amoemoe. 'Ou te alofa tele mo 'oe ma si a tā fānau. Katie, Fa'au'uga, Mālia ma Malaki, fai lenei fa'amoemoe ma fa'ata'ita'iga mo 'outou. 'Ia manuia tele tou lumana'i.

Now that I have completed this thesis, "se à se mea 'ou te taui $\bar{a}$ 'i atu $i$ le Ali' $i$ 'ona 'o lona agalelei mai uma lava iā te à'u? 'Ou te ava'e le ìpu 'o le olataga, ma 'ou vala'au atu i le Suafa 'o le Ali'i. 'Ou te avatua i le Ali'i i luma 'o lona nu'u uma lava 'o mea na 'ou tauto ai"' (Salamo 116: 12-14). Soifua!

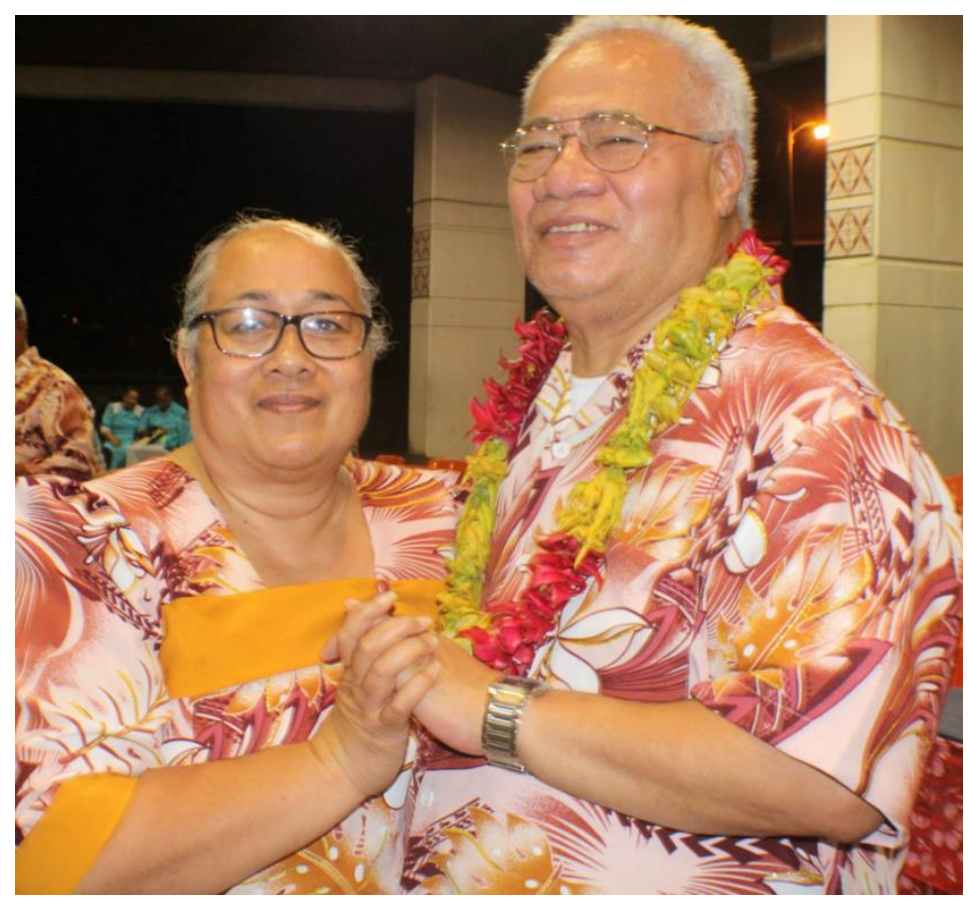

Mum and dad at Kanana Fou Theological Seminary, American Sāmoa. 


\section{TABLE OF CONTENTS}

Pg.

$\begin{array}{lr}\text { ABSTRACT } & \mathbf{2 - 3}\end{array}$

DEDICATION 4

ACKNOWLEDGEMENTS

$\begin{array}{lr}\text { TABLE OF CONTENTS } & \mathbf{8 - 1 5}\end{array}$

$\begin{array}{lc}\text { TABLES AND FIGURES } & \mathbf{1 6 - 1 7}\end{array}$

$\begin{array}{lr}\text { ABBREVIATIONS } & \mathbf{1 8 - 1 9}\end{array}$

CHAPTER ONE: FOLASAGA (INTRODUCTION) $\quad \mathbf{2 0 - 3 6}$

1.0 GAGANA AND PLACE: Setting the context 20

1.0.1 Alofa and poto: concepts for change 21

1.2 'O IGOA MATAI, TŌFIGA FA'ALELOTU MA IGOA: Naming as an agent of change

1.2.1 Igoa aloā 'ia ma le igoa papakema (Legal and baptism name) 24

1.2.2 Atali 'i 'o le faife 'au (Pastor's son) 24

1.2.3 Faipese (Choir leader) 25

1.2.4 Faiavā and tamā (Marriage and fatherhood) 25

1.2.5 Ti'ākono (Church deacon) 26

1.2.6 Tatau/Soga 'imiti (Cultural tattoo) 26

1.2.7 Faiā'oga 'o le Tôfā Manino (Lecturer) 27

1.2.8 Matai (Chief and orator titles) 28

1.2.9 Igoa fa' 'ai'u (Last name) 29

1.2.10 Fa'apu'upu'uga 'o igoa (Name truncations) 29

1.2.11 Iloiloga (A discussion) 30

$\begin{array}{lll}1.3 & \text { PACIFIC STUDIES } & 30\end{array}$

1.3.1 Academic prescriptions of Pacific Studies 30

1.3.2 Situating this research in Pacific Studies 33

1.4 KEY CONCEPTS AND TERMS 35

1.5 CHAPTER OUTLINE 35

CHAPTER TWO: ILOILOGA ‘O MAU TUSITUSIA (LITERATURE REVIEW) $\quad \mathbf{3 7 - 7 4}$ 
$\begin{array}{lll}2.1 & \text { INTRODUCTION } & 37\end{array}$

$2.2 \quad$ LANGUAGE CONTACT 38

2.3 LANGUAGE CHANGE

$2.4 \quad$ PACIFIC LANGUAGES

2.5 POLYNESIAN LANGUAGES 42

2.6 THE GAGANA SĀMOA 43

2.6.1 T-style \& $K$-style $\quad 45$

2.6.2 Everyday, respectful \& chiefly gagana 46

$2.7 \quad$ STRUCTURE OF SAMOAN SOCIETY 49

2.8 THE CONCEPT OF ORATORY

2.8.1 Oratory in the Pacific 51

2.8.2 Samoan oratory $\quad 52$

2.9 LĀUGA FA'AMATAI: Chiefly speeches 53

2.10 LĀUGA FA'ALELOTU: Sermons

2.11 SPEECHES WITHIN SPEECHES

2.12 DIFFERENCES BETWEEN THE TWO LĀUGA

2.13 FOREIGN CONTACT IN SĀMOA

2.14 STATUS AND CORPUS PLANNING 6

2.15 MISSIONS AND LANGUAGE

2.15.1 Literacy in the gagana 63

2.16 FOREIGN ADMINISTRATIONS AND LANGUAGE

2.16.1 German administration and language 65

2.16.2 New Zealand administration 66

2.16.3 New Zealand administration and language 67

2.17 THE IMPACT OF ENGLISH ON THE GAGANA

2.17.1 Dictionaries 69

2.17.2 Grammar manuscripts $\quad 70$

$\begin{array}{lll}\text { 2.17.3 Word lists } & 71\end{array}$

2.17.4 Commentaries $\quad 71$

2.18 CONCLUSION 72

CHAPTER THREE: METOTIA ILOILO 'O LE SU`ESU`EGA (RESEARCH METHODOLOGY) 
$\begin{array}{lll}3.1 & \text { INTRODUCTION } & 75\end{array}$

3.1.1 Key terms and definitions $\quad 76$

3.2 HUMAN ETHICS APPROVAL 76

3.3 PACIFIC RESEARCH METHODOLOGIES

$\begin{array}{lll}3.3 .1 & \text { Fa'afaletui } & 78\end{array}$

$\begin{array}{lll}3.4 & \text { PARTICIPANT SAMPLING } & 79\end{array}$

3.4.1 Oral sources/semi-formal interviews 79

3.4.2 Insider informants $\quad 80$

$\begin{array}{lll}3.5 & \text { CORPUS } & 83\end{array}$

3.5.1 Description 84

$\begin{array}{lll}3.6 & \text { CORPUS SAMPLING } & 72\end{array}$

3.6.1 Historical Framework (Indicator Years) 84

3.7 LĀUGA FA 'AMATAI AND LĀUGA FA 'ALELOTU:

Methodological definitions

$\begin{array}{lll}3.8 & \text { TEXT SOURCES } & 88\end{array}$

$\begin{array}{lll}3.8 .1 \text { Sulu } & 88\end{array}$

$\begin{array}{lll}3.8 .2 & \text { Sāvali } & 88\end{array}$

3.8.3 Sampling frame for corpus texts 89

3.8.4 Identifying lāuga in written form 90

3.8.5 Some observations on texts $\quad 91$

3.8.6 Corpus Size $\quad 91$

3.8.7 Piloting 92

3.8.8 Compiling and coding 93

$\begin{array}{ll}3.8 .9 \text { Inter-rater } & 96\end{array}$

3.9 $\quad$ FA'AFALETUI AND CORPUS ANALYSIS 97

$\begin{array}{lll}3.9 .1 & \text { Fa'afaletui } & 97\end{array}$

3.9.2 Corpus analysis 98

3.9.3 Lexical outcome analyses 98

3.9.4 Comparative analysis $\quad 99$

3.9.5 Quantitative analysis 99

$\begin{array}{ll}3.9 .6 & 99\end{array}$

$\begin{array}{lll}3.10 & \text { CONCLUSION } & 100\end{array}$ 
$\begin{array}{lll}4.1 & \text { INTRODUCTION } & 100\end{array}$

$\begin{array}{lll}4.2 & \text { THEMES } & 102\end{array}$

4.2.1 Missions and the impact on the gagana 102

4.2.2 Administrations and government: reflections about language planning 106

$\begin{array}{ll}\text { 4.2.3 Standardising Samoan } & 109\end{array}$

4.2.4 Transnational networks and Samoan identity 111

4.2.5 Language Change 112

$\begin{array}{lll}4.3 & \text { CONCLUSION } & 114\end{array}$

CHAPTER FIVE: 'UPU NONŌ 'I LE GAGANA (FOREIGN TYPES IN THE SAMOAN LANGUAGE)

$\begin{array}{lll}5.1 & 116\end{array}$

5.1.1 Key terms 116

5.1.2 Corpus findings sequencing 117

$\begin{array}{lll}5.2 & \text { SĀVALI FILES (1906-2014) } & 117\end{array}$

5.2.1 A short history 117

5.2.2 1906, 1944, 1977 and 2014 files 118

$\begin{array}{lll}5.3 & \text { SULU FILES (1906-2014) } & 118\end{array}$

$\begin{array}{lll}5.3 .1 & \text { A short history } & 118\end{array}$

5.3.2 1906, 1944, 1977 and 2014 files 119

$\begin{array}{lll}5.4 & \text { CATEGORIES } & 120\end{array}$

$\begin{array}{lll}5.5 & \text { SĀVALI 1906 FILES } & 121\end{array}$

5.5.1 Table 8 Analysis 122

5.5.2 Place Names 122

5.5.3 Proper Nouns 123

5.5.4 Religious Culture 123

5.5.5 Social Culture 124

5.5.6 Material World 125

$\begin{array}{lll}\text { 5.5.7 Natural Environment } & 125\end{array}$

$\begin{array}{lll}5.5 .8 \text { Other } & 126\end{array}$

5.5.9 Overview of Sāvali 1906 findings 126 
5.6.1 Table 9 Analysis 127

$\begin{array}{lll}\text { 5.6.2 Place Names } & 127\end{array}$

$\begin{array}{lll}\text { 5.6.3 Proper Nouns } & 128\end{array}$

5.6.4 Religious Culture 129

5.6.5 Social Culture 130

5.6.6 Material World 130

5.6.7 Natural Environment 131

5.6.8 Other 132

5.6.9 Overview of Sulu 1906 findings 132

5.7 SĀVALI 1944 FILES:

5.7.1 Table 10 Analysis 133

5.7.2 Place Names 134

5.7.3 Proper Nouns 134

5.7.4 Religious Culture 136

$\begin{array}{lll}\text { 5.7.5 Social Culture } & 139\end{array}$

5.7.6 Material World 141

5.7.7 Natural Environment 143

5.7.8 Other 143

5.7.9 Overview of Sāvali 1944 findings 143

$\begin{array}{lll}5.8 & \text { SULU } 1944 \text { FILES } & 144\end{array}$

5.8.1 Table Eleven Analysis 144

5.8.2 Place Names 144

5.8.3 Proper Nouns 145

5.8.4 Religious Culture 147

$\begin{array}{lll}5.8 .5 \text { Social Culture } & 149\end{array}$

5.8.6 Material World 151

5.8.7 Natural Environment 152

$\begin{array}{lll}5.8 .8 \text { Other } & 152\end{array}$

5.8.9 Overview of Sulu 1944 findings 152

5.9 SĀVALI 1977 FILES:

5.9.1 Table 12 Analysis 153 
5.9.2 Place Names 154

5.9.3 Proper Nouns 155

5.9.4 Religious Culture 157

5.9.5 Social Culture 158

5.9.6 Material World 163

5.9.7 Natural Environment 167

5.9.8 Other 168

5.9.9 Overview of Sāvali 1977 findings 168

$\begin{array}{lll}\text { 5.10 SULU 1977 FILES: } & 168\end{array}$

5.10.1 Table Sixteen Analysis 169

5.10.2 Place Names 169

$\begin{array}{lll}5.10 .3 & \text { Proper Nouns } & 170\end{array}$

5.10.4 Religious Culture 171

5.10.5 Social Culture 172

5.10.6 Material World 174

5.10.7 Natural Environment $\quad 175$

5.10.8 Other 175

5.10.9 Overview of Sulu 1977 findings 175

5.11 SĀVALI 2014 FILES: 176

5.11.1 Table Seventeen Analysis 176

5.11.2 Place Names 177

$\begin{array}{lll}5.11 .3 & \text { Proper Nouns } & 178\end{array}$

5.11.4 Religious Culture 179

$\begin{array}{lll}5.11 .5 & \text { Social Culture } & 181\end{array}$

5.11.6 Material World 186

5.11.7 Natural Environment 189

$\begin{array}{lll}5.11 .8 \text { Other } & 191\end{array}$

5.11.9 Overview of Sāvali 2014 findings 191

5.12 SULU 2014 FILES: $\quad 191$

5.12.1 Table Eighteen Analysis 192

5.12.2 Place Names 192

5.12.3 Proper Nouns 194 
5.12.4 Religious Culture 195

5.12.5 Social Culture 196

5.12.6 Material World 199

5.12.7 Natural Environment 203

5.12.8 Other 204

5.12.9 Overview of Sulu 2014 findings 204

5.13 ILOILOGA TĀUA: Main Findings 205

5.13.1) Key points from Table Nineteen 206

5.13.2) Key points from Table Twenty 208

5.14 AOTELEGA: Conclusion 210

CHAPTER SIX: FA'ATALANOAGA (DISCUSSION)

$\begin{array}{lll}\text { 6.1 INTRODUCTION } & 211\end{array}$

6.2 FA'AFALETUI AND CORPUS FINDINGS: A Discussion 212

6.2.1 Missionary influence 212

6.2.2 The influence of English 213

6.2.3 Written Samoan 214

6.2.3.1 Samoan and foreign type orthography 215

6.2.3.2 Diacritical marks 216

6.2.4 Lexical shift 217

6.3 LEXICAL OUTCOMES OF LANGUAGE CONTACT: 218

6.3.1 Hybrid and Neologisms in the gagana 219

6.3.2 Some thoughts on LOLC 222

6.4 LĀUGA FA'AMATAI AND LĀUGA FA'ALELOTU: An Analysis 224

6.5 CONCLUSION 229

CHAPTER SEVEN: AOTELEGA (CONCLUSION) $\mathbf{2 3 1 - 2 4 5}$

$\begin{array}{lll}7.1 & \text { INTRODUCTION } & 231\end{array}$

7.2 RESPONSES TO THE RESEARCH QUESTIONS 232

7.2.1 RESEARCH QUESTION 1

7.2.2 RESEARCH QUESTION 2

7.2.3 RESEARCH QUESTION $3 \quad 236$ 
7.3 RELEVANCE TO PACIFIC STUDIES

7.4 METHODOLOGICAL ADVANTAGES 238 OF FA'AFALETUI AND CORPUS

7.4.1 Methodological advantages of fa 'afaletui 239

7.5 RESEARCH CHALLENGES 240

7.6 RESEARCH LIMITATIONS AND FUTURE RESEARCH 241

$\begin{array}{lll}7.7 & \text { FINAL REMARKS } & 243\end{array}$

$\begin{array}{lr}\text { REFERENCES } & 245\end{array}$

$\begin{array}{lr}\text { APPENDICES } & 263\end{array}$

APPENDIX ONE: $\quad$ Ethics approval 263

APPENDIX TWO: Information sheet 264-265

$\begin{array}{ll}\text { APPENDIX THREE: } \quad \text { Participant Consent form } & \text { 266-267 }\end{array}$

APPENDIX FOUR: Fa'afaletui questions 268

APPENDIX FIVE: Glossary 269-276 


\section{TABLES AND FIGURES}

\section{TABLES}

Table 1: $\quad$ Every day, respectful and chiefly language $\quad 42$ (pg.)

Table 2: $\quad$ Samoan Ceremonies and Läuga Types $\quad 50$

Table 3: $\quad$ Social and religious status of Insider informants 71

$\begin{array}{lll}\text { Table 4: } & \text { Text Sampling Frame } & 77\end{array}$

$\begin{array}{lll}\text { Table 5: } & \text { Sulu and Sāvali sampling }\end{array}$

Table 6: $\quad$ Coding Template 82-83

$\begin{array}{lll}\text { Table 7: } & \text { Sulu and Sāvali Issues Obtained }\end{array}$

$\begin{array}{lll}\text { Table 8: } & \text { Categories/Types/Tokens: Sāvali } 1906 & 107\end{array}$

$\begin{array}{ll}\text { Table 9: } \quad \text { Categories/Types/Tokens: Sulu } 1906 & 111\end{array}$

Table 10: $\quad$ Categories/Types/Tokens: Sāvali $1944 \quad 116$

Table 11: $\quad$ Categories/Types/Tokens: Sulu $1944 \quad 126$

Table 12: $\quad$ Categories/Types/Tokens: Sāvali $1977 \quad 134$

Table 13: $\quad$ Governance Types $\quad 139-140$

$\begin{array}{lll}\text { Table 14: } & \text { Tribunal types } & 141-142\end{array}$

Table 15: $\quad$ Monetary and Security types 142

$\begin{array}{lll}\text { Table 16: } \quad \text { Categories/Types/Tokens: Sulu } 1977 & 148\end{array}$

Table 17: $\quad$ Categories/Types/Tokens: Sāvali 2014

$\begin{array}{lll}\text { Table 18: } \quad \text { Categories/Types/Tokens: Sulu } 2014 & 168\end{array}$

$\begin{array}{llr}\text { Table 19: } & \text { Sulu 1906-2014 } & 180\end{array}$

$\begin{array}{lll}\text { Table 20: } & \text { Sāvali 1906-2014 } & 181\end{array}$

$\begin{array}{lll}\text { Table 21: } & \text { Foreign type orthography } & 190\end{array}$ 
Table 22: $\quad$ Lexical Outcomes of Language Contact (LOLC) for Samoan Types

Table 23: Hybrid and Neologism Lexical Constructions in the gagana Sāmoa

Table 24: $\quad$ Lexical Outcomes of Language Contact Types

\section{$\underline{\text { FIGURES }}$}

Figure 1: Diachronic (Indicator Years) and Contact Period

(pg.)

Figure 2: $\quad$ Macalister's (2007) Lexical Outcomes of

Language Contact Categories

Figure 3: $\quad$ Total Category Types in Corpus

Figure 4: $\quad$ Total Types for Sāvali and Sulu 1906-2014 


\section{ABBREVIATIONS}

AOG

ASC

CCCAS

CCCS

CIM

EFKS

FAOUN

ICE

KFTS

LMS

LOLC

LS

LTC

MTC

MW

NE

NMPL

NUS

NZA

NZNL

OTH
Assembly of God

Arabic Speech Corpus

Congregational Christian Church of American Sāmoa

Congregational Christian Church of Sāmoa

Cook Island Māori

'Ekālesia Fa'apotopotoga Kerisiano 'i Sāmoa

Food and Agriculture Organisation of the United

Nations

International Corpora of English

Kanana Fou Theological Seminary

London Missionary Society

Lexical Outcomes of Language Contact

Language Shift

Land and Titles Court

Mālua Theological College

Material World

Natural Environment

Nelson Memorial Public Library

National University of Sāmoa

New Zealand Administration

New Zealand National Library

Other 
PLN

PN

PNG

PPE

$\mathrm{RC}$

SC

SIDS

SLTC

SNZE

STTC

UCTD

UNESCO

VUW

WHO

WNZE
Place Names

Proper Nouns

Papua New Guinea

Papuan Pidgin English

Religious Culture

Social Culture

Small Island Development States

Sāmoa Lands and Titles Court

Spoken New Zealand English

Sāmoa Teachers Training College

United Conference on Trade and Development

United Nations Educational Scientific and Cultural

Organisation

Victoria University of Wellington

World Health Organisation

Written New Zealand English 


\section{CHAPTER ONE}

\section{FOLASAGA}

Introduction

In pre-Western Sāmoa, local knowledge was conveyed orally and in the form of motifs known as tusi (pictograph/design). Tusi were inspired by and exemplified Samoans' admiration of and respect for fanua (land), sami (sea) and lagi (sky), as the physical realms which provided spiritual and emotional sustenance to their existence. Using the $o$ ' $a$ dye, tusi were imprinted on the bast of siapo (bark cloth), which were made from $u$ ' $a$ (paper mulberry tree), using the $o$ ' $a$ or lama dye extracted from the bark of local trees. As the ancient form of writing, tusi not only emulated Samoans' social and natural contexts, but most importantly became the source of the gagana tautala (spoken language). A glance at alaga 'upu and muāgagana (Samoan metaphorical expressions), for instance, clarifies this.

As it were, Samoans wore tusi motif siapo everywhere and so were clothed in the gagana wherever they went. To be clothed in the gagana refers to Samoans traditional use of siapo as ceremonial and everyday garments, cultural gifts, bedding, partition for open houses and burial shroud (Tau'ili'ili, 1997, p. 6). Siapo were also passed down from generation to generation and became family heirlooms (Tau'ili'ili, 1997, p. 6). In the form of tusi, Samoans' pre-Western writing was the inextricable link between Samoans and their natural environment.

But this all changed with the introduction, fascination and adoption of Western writing. For many reasons, one of which regarded foreign orthography as more superior to the local one, it was not long before Western orthography displaced tusi. Since then, the encounter between Western orthography and local tusi became the embodiment of two things: (1) a growing disconnect with local epistemologies (such as tusi) and, (2) the beginning of ideological contact between Samoan and Western epistemologies.

Over time, ongoing social contact with Europeans has transformed Samoans' way of life. Foreign agencies, such as lotu (church), mālō (government) and galuega (workplace), for instance, brought new ways of being and became contexts where new vocabularies were 
created. While indigenous communal groups, such as the 'äiga (family) and $n u$ ' $u$ (village) continued to be central in Samoan interactions, these became influenced by foreign ideologies. Communalism, as a central aspect in Samoan family relations, for instance, was being challenged by Western understandings of individualism.

My first language is the gagana, which I am a fluent speaker of and have been exposed to since birth. To reflect on what has been said in the preceding paragraphs, the gagana that I speak, write and use, which is situated in the contexts of 'äiga (family), nu'u (village), 'ekālesia (church), $\bar{a}$ 'oga (school) and falefaigaluega (work), is a direct product of the histories of my people.

As a result, I developed a fascination with how the gagana has come to reflect these histories, or more specifically, social contact. Even more so, I began to think and reflect on how the lotu and $m \bar{a} \bar{o}^{2}$, as introduced agencies, have contributed to change. More precisely, I became intrigued with how, in what way(s), and to what extent, the gagana has changed over time.

In pre-Western Sāmoa, religion and politics were the pillars and source of Samoan culture and way of life. The arrival and acceptance of the lotu and $m \bar{a} l \bar{o}$, therefore, became the two most influential mediums of social and linguistic change. As a result, my reflections and thoughts have become the ingredients for a desire to want to know more about these processes.

I begin by doing two things: (1) I explore the depths and nuances of indigenous Samoan words, and address how these words continue to be lexical and living reminders of our pre-colonial past and (2), I signal how wider social changes have influenced who I am as a Samoan. Both accounts are personal and speak to the complexities of gagana socialisation and change.

\subsection{1) Alofa and poto: concepts for change}

When we moved to New Zealand from Sāmoa in 1984, I was three years old, and have no recollection of the event. But like many Samoan 'āiga who emigrated to places like New Zealand, Australia and the United States mainland, the decision to do so was founded on a collective vision for a prosperous life, something which was difficult in Sāmoa at the time because of limited education and employment opportunities. Often recalled by our parents

\footnotetext{
${ }^{2}$ Mālō here refers to the formal Western central government rather than the pre-contact village and district polities.
} 
during our daily lotu afiafi (family evening prayers), our move was fuelled by two key aspects: (1) alofa (love) and (2) poto (knowledge).

From an indigenous lens, alofa is comprised of the words alo and fa. Alo has many meanings in the gagana. These include 'o lou alo (your child-alo is the respectful term for child) and alo le va'a (paddle the canoe) Alo can also mean, as Pratt (1862, p. 71) noted, 'the seat of affections, and of feelings.'. In alofa, however, alo is used to mean to face. In one account, alo refers to the four sides of a Samoan fale. These are the two matuatala (sides of the house), the talāluma (front of the house) and talātua (back of the house). In another account, alo can also refer to the four sides of a person, known as alo 'i luma (front), alo 'i 'autafa (a person's left and right sides) and alo 'i tua (literally a person's back side). The term $f a$ refers to the number four. Jointly, it is only when all four alo are considered, respected and in harmony, that alofa in the Samoan culture can be achieved.

The term poto means knowledge. It is comprised of two words: po and to. Here, po means dark and is also the term for night. Po can also mean blind. To means to cease, or halt. To be poto, therefore, requires po to be to or darkness to cease. Leaving Sāmoa for better opportunities in life, at least for our 'aiga, can be considered to have been a decision based on poto. On a much larger scale, Samoans' conversion to Christianity is commonly acknowledged as the day that po (darkness) in Sāmoa became to (ceased) through the acceptance of the Talalelei (Good Word). The Talalelei displaced fanaafi 'o fa 'amalama, as the indigenous form of worship, and replaced it with lotu and afiafi.

I recall the use of the terms lotu and afiafi by my grandparents while I was living in Sāmoa. The term was and still is used to refer to evening prayer. What is fascinating about the use of the term afiafi is context. When my late grandparents on my father's side, Tuimuai'ava Ioane and Asosa'asa'a Tuimuai'ava, who were devoted Congregationalists, called out to òmai e fai le afiafi (come to worship), it meant that evening worship would be conducted without a pese lotu (hymn). As ardent Catholics, my late grandparents on my mother's side, Leatuāvao Matai'a Fa'alata Leatuāvao and Tagisia Vaisigano Leatuāvao, did not use this phrase but instead called us to lau le losalio (recite the rosary) when it was time for evening devotion. The inter-denominational differences in these phrases never struck me until now.

But there were also intra-denominational nuances in the use of the gagana. To describe, the term afi (fire) is duplicated in afiafi. Afi was central in Samoa's indigenous worship or fanaafi 
'o fa 'amalama (Le Tagaloa, 2003). Fanaafi (fana a 'e afi) means to initiate fire. Things changed when the word lotu, which generally means worship, and which was integrated into the gagana from Tonga, was introduced by Christian missionaries in the 1830s. Unlike ō mai e fai le afiafi, the expression ò mai e fai le lotu meant a Christian hymn would be sung before and after prayer. The semantic and contextual differences between afiafi and lotu signal Samoa's indigenous and Christian religions respectively. Equally significant, when the call is to o mai e fai le lotu afiafi, the ascendency of Christianity in Sāmoa is highlighted, with the phrase lotu afiafi meaning evening worship with Christian hymn and prayer.

Considering the words alofa, poto, afiafi and lotu in this way can give us a sense of how the gagana is a lexical documentary of our past and present. But the words alofa, poto, afiafi and lotu have only demonstrated how social change has influenced my communal existence. It has not demonstrated how social and language change has affected me as a person. In the following section, I demonstrate how my own names are representations of social and language change. The discussion highlights how my names, which consist of both indigenous and foreign origins, have influenced who I am today, both as a person and as a Samoan.

1.2) 'O IGOA MATAI, TOFIGA FA'ALELOTU MA IGOA: Naming as an agent of change

Growing up in New Zealand, Sāmoa and American Sāmoa, I developed a love and fascination for the gagana (and aganu' $u$ (culture)). I became intrigued at how the gagana was spoken in the 'aiga, nu' 'u, 'ekālesia, à' 'oga and falefaigaluega, both in the homeland and in the diasporic community setting.

Over time, I became reflective of the changes that were unfolding. Changes in the use of the gagana in the presentation of cultural gifts, such as the sua (highest form of cultural gift), for instance, amazed yet worried me. I was amazed at the adaptability of the gagana. But I worried and still worry that in the midst of adapting to social changes, we begin to lose some of the fundamental Samoan essences of and values carried by the gagana.

In my view, the church and government, as sites of power and influence, have been at the forefront of changes to the gagana. To illustrate my point, I discuss how my own names reflect the collision and marrying between indigenous and foreign contact. 


\subsubsection{Igoa aloā'ia ma le igoa papakema (Legal and baptism name)}

At birth, I was named Sadat, an Egyptian name, by my father, Malaki Tuimuai'ava, after hearing it on the local radio in Sāmoa in 1981. The name to him was different and brought prestige, as all foreign names did in those days, my father recalls. But in those days having a non-Samoan name was common and largely encouraged. Samoa's current Prime Minister Tuila'epa Sa'ilele Malielegaoi (2017, p. 45) recalls the government school criteria where students were required to "have an English name to attend government school." My mother, Rosalili Tuimuai'ava, whose family is Catholic and who attended Ioane Pope Paulo (John Pope) College in Leulumoega, also recalls that entry into Catholic schools was dependent on being baptised in the Catholic Church, with a Catholic name.

My papakema (baptism) name is Petelo, a transliteration of the English name Peter. Petelo is also my igoa vala 'au (calling name at home). Papakema is the Catholic word for the English word baptism. In the Congregational denomination, however, baptism is known as papatiso. Lexical variation between denominations is very common.

My papakema in the Catholic Church came about due to my late grandparents on my mother's side, who were staunch Catholics, objecting to my father's family's preferences for a Congregational papatisoga $a^{3}$. My father's parents did not oppose. But to be baptised I had to have a Catholic name. Even today, a common practice in Samoan naming conventions is to rename children after a family elder. As a result, my mother named me Petelo, after her older brother. Both the names Sadat and Petelo are legal names. In a sense, both have also become secular and non-secular identification markers, respectively. But I was to receive more names, and the social responsibilities that came with them.

\subsubsection{Atali 'i 'o le faife 'au (Pastor's son)}

The term faife 'au, which consists of the verb fai (to do) and the noun fe 'au (task/message), was coined during LMS missionisation in Sāmoa in the mid-nineteenth century to exemplify the role of faife 'au as messengers (Lange, 2006).

After my parents graduated from Kanana Fou Theological Seminary (KFTS) in 1998, a Congregational seminary in American Sāmoa, they were called to minister at one of its

\footnotetext{
${ }^{3}$ Papatisoga is the noun form for papatiso, a verb
} 
congregations located in Wainuiomata, Wellington, in November 2000. Since then, I became known as a faife 'au's son. Entering the parsonage at the age of seventeen, it was challenging, particularly familiarising myself with newly ascribed responsibilities and stereotypes associated with fänau a faife 'au (Samoan clergy children). As challenging as the role is, with expectations come privileges. The expectation to be good role models to the youth of the congregation is counterbalanced, for instance, by the privilege of respect given by the congregation, particularly in cultural festivities, to fānau a faife 'au. I remain a faife 'au son today.

\subsubsection{Faipese (Choir leader)}

A couple of years after our family arrived in Wellington, our faipese (piano player/choir master), a musically gifted individual, along with his nephew, who was also one of our pianists, and their family left church to return to the United States. For the next three years, hymns were sung unaccompanied. In the Congregational denomination, the main instrument for church services is the piago (a transliteration of the English word piano). All other instruments are regarded as unsuitable in worship. So, though our church had talented guitarists and drummers, no one knew how to play the piago. For my father, the absence of the piago in services was heavy on his mind. This was because in theological school, they were reminded about the importance of music in ministry.

One day, after a series of conversations with my father, I began $\bar{a}$ 'oga piago (piano lessons). Because there was a sense of urgency to hear the piago in church again, I played my first pese lotu (church hymn), pese (hymn) number eight, named E lelei 'o mea 'uma (All is well), after only three months of learning. I remember it vividly, not because I played it during our lotu Kerisimasi (Christmas service), but because of how nervous I was and the mistakes I made. Looking back, learning the piago was like learning a whole new language, which I am still learning. Nonetheless, after having been taught over forty songs, I remain the faipese for our congregation to this day and continue to contribute to our parents' vocation through music.

\subsubsection{Faiavā and tamā (Marriage and fatherhood)}

In 2004, I became a faiavā (in-law) and a $\operatorname{tam} \bar{a}$ (father) in the same year. Unlike the novel status of becoming a faife ' $a u$ son, and the self-imposed role of becoming a faipese, the roles of 
faiavā and tamā were familiar having being modelled to me by my father and uncles. In Samoan custom, when a man marries, he is known as a faiava (in-law). As faiavā, the term alludes to the social and cultural responsibilities of in-laws, one of which is tautua (service) to his wife's family. My roles of faife 'au son, faipese, faiavā and tamā are all learned and have been constructed by family and societal expectations and stereotypes.

\subsubsection{Ti'ākono (Church deacon)}

I was ordained a $t i$ 'ākono (deacon) in 2013. In the Congregational denomination, a ti 'ákono's

roles range from the collection and public announcement of donations to the distribution of fa 'amanatuga (Holy Communion, as it is known in the Catholic Church). The status of $t i$ ' $a \bar{k} k o n o$ is likened to that of a matai (chief/orator). Like matai, ti 'ākono are considered the tüläfale (talking chiefs) of a congregation. My status as a $t i$ ' $\bar{a} k o n o$, however, was complicated by being a faife 'au son. To speak at events on behalf of our congregation, for instance, whose spiritual parents were also my biological parents, was unsettling.

\subsubsection{Tatau/Soga imiti (Cultural tattoo)}

When an individual is accepted into Christian theological colleges to train to become a faife 'au, and in the event that he or his wife hold matai titles, these titles are no longer used and recognised in the ministry. Instead, only legal and papakema/papatiso names are valid. For non-clergy roles, such as $t i$ ' $a$ kono, they are also prohibited from partaking in secular activities, but these vary between denomination. One of these activities is tatau.

In 2013, over the course of three days and after twenty-four hours of tattooing time, I completed my tatau (traditional male body tattoo), also known as soga imiti. The tatau, considered by many Samoans as an ancient system of writing, is a chart of deeds that symbolise one's social and cultural obligations to his/her 'äiga, nu' $u$ (village) and 'ekālesia (church congregation) (Muai'ava, 2018).

Also known as a $l \bar{a}$ 'ei (traditional clothing), the missionaries tried to ban tatau. Though they were unsuccessful, a sense of guilt around tatau as a heathen practice lingers. Today, and regardless of denomination, all clergy are prohibited by the Church to receive the tatau. My father, who entered the ministry with his tatau which he completed when he was nineteen, is 
prohibited to show his tatau. In some denominations, laymen and $t i$ ' $\bar{a} k o n o$ are also forbidden from getting the tatau. Fortunately for me, the Congregational Christian Church of American Sāmoa (CCCAS) does not prohibit the tatau on $t i$ ' $\bar{a} k o n o$. There are no prohibitions for children of faife ' $a u$, also. Amidst the influences of Christianity, the tatau continues to be worn proudly by many Samoans today. However, its practice and display remains overshadowed by nonsecularistic bias.

\subsubsection{Faīa'oga 'o le Tōfā Manino (Lecturer)}

My parents were ecstatic when I was appointed a lecturer in the Samoan Studies programme at Victoria University of Wellington (VUW). For them, particularly my father who was a former teacher and graduate of Sāmoa Teachers Training College (STTC), our achievements were living fulfilments of our grandparents'alofa and vision for poto.

I have been teaching the gagana Sāmoa at VUW for almost nine years now, where I currently co-ordinate three papers. These are Introduction to the Samoan Language (SAMO101), Samoan Language and Oratory (SAMO201) and Samoan Language and Customs (SAMO301). It has been both a rewarding and a challenging experience.

One of the most rewarding aspects about teaching the gagana at the tertiary level is the satisfaction I get from being able to assist students in their pursuit of learning the gagana, either as their heritage language or as a language with which they have had some connection to in the past or one to which they perceive to be key to their future aspirations. Non-Samoan students fall into the two latter categories. In the past, for instance, I have tutored the two most recently appointed New Zealand High Commissioners to Sāmoa.

Another rewarding aspect about teaching the gagana is continued learning. As an educator, I learn from my students daily. My conversations with them enable me to remain in contact with the ever-changing Samoan discourses, such as youth discourse. Because my students are members of various church denominations, my knowledge of church vocabularies is also enhanced. These experiences, along with others, are rewarding because what I have realised is that the gagana is the fatu (heart) that enables my students to connect, re-connect and establish their sense of Samoanness. 
As a teacher of the gagana, the tertiary teaching profession requires that teaching is informed by research. From a researcher's perspective, it goes without saying that I, along with my colleagues in Samoan Studies, whether at VUW or elsewhere, have an obligation and responsibility to conduct research about the gagana. Unfortunately, however, this is an area that has been neglected. In my own opinion, I find that much of the research that needs to be done regarding the gagana requires more quantitative analysis. An increase in more quantitative analysis will complement the qualitatively dominated research we currently have. As a result, I have made this point a central component to the work in this thesis (see Chapter Three).

But with rewards come challenges. And there are many. I will provide only a few, however. Firstly, the obvious challenges are to do with enrolment and growth. Much of these challenges are linked to existing student perceptions that learning one's heritage language is either non-academic or an indication of one's cultural insecurities. In saying that, this is likely to continue in today's unstable tertiary climate where growth and development are constant issues nationwide.

Another key challenge of teaching the gagana at university, which I know is not so obvious, is the reality that from the outside (community) there is an expectation that lecturers in Samoan Studies have more appeal as cultural experts than as people who are knowledgeable in the gagana. But while this perception is still quite strong, more and more Samoans are becoming interested in research about the gagana. Could this be a key contributor to the stagnant literature about the gagana? I believe so! As lecturers, therefore, we are tied between both institutional and community expectations.

\subsubsection{Matai (Chief and orator titles)}

One of the most significant events in my life was when I received my matai titles between 2012 and 2015. In order of bestowment, I received the Le'ausālilō title from my mother's family and village in Faleāse'ela. I was then bestowed the chief title Lupematasila from my mother's family in Falelātai. The orator titles Fata and 'Au'afa, were bestowed on me by my wife's mother's and father's families in Afega and Lotofaga (Atua), respectively.

An important aspect of matai titles are the fa 'alagiga (honorific) appellations that some titles have. The Lupematasila title, for instance, has the appellation Fa'aaloaloga. The Le'ausālilō 
title has the appellation To 'oto 'o 'o Ma'auga. The Fata title, a paramount district orator title, has the appellation of Tu'itu' $i$ 'o le Gato 'aitele. These appellations point to the origins and significance of the titles in village and district hierarchy. Although, all matai titles are registered at the Land and Titles Court in Sāmoa, making matai titles legal names. But the legality of these titles, as mentioned above, are deemed irrelevant in the Church's ministry, although matai titles can be used in church by non-clergy, such as $t i{ }^{\prime} a \bar{k} k o n o$. However, unlike the ambiguity that comes with being a faife' $a u$ son, faipese and $t i$ 'ākono (all church related roles and names), there are clear boundaries between matai titles. The role distinctions between a high chief and an orator, for instance, are unambiguous in that high chiefs have a more mediatory role while orators are more proactive in village gatherings.

\subsubsection{Igoa fa'ai'u (Last name)}

My last name, Tuimuai'ava, or Muai'ava in writing, is a tūlāfale title in my father's family. The title connects me to my father's family in the village of Sāfa'ato'ā, where the title is from. It is the founding title of that village including the district of Lefaga.

My father never favoured using his birth name as our last name, a practice common for his siblings and in Samoan families in general. Instead, he used our family title. For him, using our family title was an identity marker we could connect to and represent in our everyday lives. Malielegaoi (2017, p. 35) notes that "[In Sāmoa] we never had any surname until the Europeans introduced the practice we now follow. You took the chiefly title of your father to be your surname." (Malielegaoi 2017, p. 35). Each with its own oral history, all matai titles are living representations of Samoa's pre-colonial past.

\subsubsection{Fa'apu'upu'uga'o igoa (Name truncations)}

As is the case in speech, truncations are common in Samoan names. In many instances, I have been called Sa or Dat for Sadat; Kelo, Tels or PK as a variant of Petelo; Sālilō and Le 'au as shortened versions for Le'ausālilō; and Lupe or Sila when referring to Lupematasila. But not all names are shortened, however. The matai titles Fata and 'Au'afa, for instance, are not truncated in spoken Samoan. In fact, to shorten the syllable structure removes and disregards reference to the original name. 


\subsubsection{Iloiloga (A discussion)}

Like all languages, the gagana Sāmoa, through social contact with missions and government in particular, has undergone considerable changes. As a case in point, the discussion about the gagana and names in this chapter has demonstrated the notion that social change influences both communal (such as faife 'au son and faipese) and individual (such as Sadat and Petelo) existence. The discussion also points to the idea that changes to the gagana are bound by the contesting and marrying of indigenous and foreign ideologies. In turn, these processes reflect the ongoing variability of the social environment. Furthermore, names, as social status, carry the weight of history. We bear this weight and find that our identities as people are continually dictated and shaped by not only names, but the gagana that names them.

As a thesis about gagana change over time, Section 1.3 discusses how this study aligns with the disciplinary field of Pacific Studies.

\section{3) PACIFIC STUDIES}

\subsubsection{Academic prescriptions of Pacific Studies}

Pacific Studies, as a field of scholarship, has its origins in anthropology at the University of Hawai' $i$ and political history at the Australian National University (Teaiwa 2009). One of the dominant conversations held in Pacific Studies by Pacific and non-Pacific academics who conduct and have interests in Pacific-related research, has been the question: What constitutes Pacific Studies research?

This question has been discussed openly by academics such as Wesley-Smith (1995) and Teaiwa (2009). Wesley-Smith argues for research in Pacific Studies to be based on three rationales. The first rationale, the pragmatic rationale, endorses research in Pacific Studies as being situated in the Pacific and about the Pacific. The second rationale, named the laboratory rationale, considers Pacific Studies research as research that contributes to wider scholarship. The third and final rationale, which he calls the empowerment rationale, characterises Pacific Studies research as research which empowers and values the voices of Pacific peoples and communities.

While acknowledging Wesley-Smith's contribution to the contours of Pacific Studies, Teaiwa (2009) articulates that Pacific Studies research should include three prescriptions: (1) 
interdisciplinarity, (2) indigeneity and (3) comparativity. In her description of these prescriptions, Teaiwa begins with the premise that as Pacific academics, we should not strive for an authentic form of Pacific Studies scholarship. My interpretation of Teaiwa's caution is based on the notion that to propose an authentic form of Pacific Studies is problematic because it has the potential to draw on and reflect the ideological premise of nationalistic ethnocentrism, which is more characteristic of Native or Indigenous Studies. Her argument becomes the foundation for her proposal of interdisciplinarity, indigeneity and comparative prescriptions for Pacific Studies.

For the first prescription, Pacific Studies research should be interdisciplinary in the sense that it draws knowledge from and contributes to existing disciplines. As an example, research about language, such as this one, should draw knowledge from existing disciplines such as linguistics and socio-linguistics and Pacific Studies in ways that recognise their complementarity and inter-dependence.

In regards to the indigeneity prescription, for too long indigeneity has become a catchphrase for the ownership of local knowledge which can block critical investigation (Teaiwa 2009). The distinctions between Māori indigeneity, as articulated by Walker (2019, p. 3 \& 4), for instance, lies in the differences in whanauga (kin), iwi (tribe) and hapu (sub-tribe). These distinctions, as a result, elucidate the idea that indigeneity is constructed differently within cultures. In fact, Gegeo and Watson-Gegeo (2001) agree in their discussion of how indigenous knowledges are constructed differently within villages in the Solomon Islands. Samoa's former Head of State Tui Atua Tupua Tamasese Ta'isi Tupuola ‘Efi's (2008b, p. 17) work on Samoa's indigenous reference ${ }^{4}$ provides a Samoan context when he highlights the propaganda associated with the construction of knowledge surrounding Samoan geneaology and honorifics.

The claims and counter-claims regarding the validity of knowledge is at the centre of Teaiwa's concern. Her concern lies in the claims and counter-claims of indigenous knowledge, which tend to dominate and exclude, rather than to empower for mutual exchange and dialogue. What is required, she continues, is a willingness to be critical, to attempt objectivity and to examine issues from as many relevant perspectives as possible (Teaiwa 2009, p. 117). However, objectivity has been largely criticised by indigenous scholars as a principle of Western research.

\footnotetext{
${ }^{4}$ Samoa's indigenous reference refers to pre-Western ways of knowing and being.
} 
According to Tuhiwai-Smith (1999, p. 137), objectivity is problematic in research lead by Maori/Pacific and about Maori/Pacific topics. While Western research promotes objectivity, where the researcher is encouraged to be distant in the researcher-researched relationship, for Maori/Pacific researchers, a connectedness to Maori/Pacific communities is crucial to ensure the maintenance of cultural protocols and that the perceptions of Maori/Pacific voices are represented accurately and not marginalised in research.

To be objective and critical of indigenous knowledge brings forth the openness to be comparative, which is the third prescription. In her discussion of the comparative prescription, Teaiwa does not propose that Pacific Studies research cannot focus on a single ethnic group. Rather, in her encouragement to attempt objectivity and critical reflections in Pacific research, employing a comparative approach of how themes that emerge from research operate or resonate across ethnic groups and sites, will enable a better objective understanding of the wider social, political, religious and economic significance of the region. So what is it about Wesley-Smith and Teaiwa's prescriptions that help drive Pacific Studies as a distinctive discipline? In addition, what do their prescriptions offer this thesis? I discuss these questions separately.

When considering the prescriptions provided by Wesley-Smith (laboratory, pragmatic and empowerment) and Teaiwa (interdisciplinarity, indigeneity and comparativity), the difference between Pacific Studies and other academic disciplines, such as linguistics and anthropology, for instance, is the certitude that through Pacific Studies scholarship, and using Pacific frameworks, Pacific indigenous knowledge, and its historically significant contributions to scholarship, is valid. In addition, believing that these knowledges have been largely misrepresented and peripheral in Western research, Pacific Studies offers significant prescriptions for not only decolonising Pacific research, but also a scholastic medium where Pacific methodologies and methods are promoted and advanced. As one of Samoa's, and the Pacific's, distinguished academics, Albert Wendt (1976, p. 49), articulately puts it, Oceania is:

“...So vast, so fabulously varied a scatter of islands, nations, cultures, mythologies and myths, so dazzling a creature, Oceania deserves more than an attempt at mundane fact."

In terms of this thesis, Wesley-Smith and Teaiwa's prescriptions offer this thesis, both conceptually and methodologically, the precepts to conduct research that endorses and respects not only the validity of Pacific knowledge on 'objective' Pacific terms, but also acknowledges 
how our communities as the custodians of knowledge do not ghettoise our knowledges or languages so that it becomes itself oppressively exclusive or insular.

\subsubsection{Situating this research in Pacific Studies}

This thesis is situated within the academic rationales and prescriptions of Pacific Studies. Although this project does not attend to all of the rationales and prescriptions proposed by Wesley-Smith (1995) and Teaiwa (2009), it does tend to some significant areas.

Firstly, this study about language change in gagana Sāmoa over time offers Pacific Studies a useful case-study from which to understand the deeper impacts of historical colonisation on Pacific indigenous languages, and the internalisation of those changes within Samoan society. So how can we have a deeper understanding these impacts and changes?

We can understand firstly through the concept of interdisciplinarity. I understand interdisciplinarity in Pacific Studies to be an approach that not only acknowledges mainstream Western disciplines but strives to stand outside such disciplines so as to be able to formulate projects without the limitations which are embedded in Western views of research. In doing so, and as Fairbairn-Dunlop (2008, p. 47) encourages us to do, we must draw on multiple communities of knowledge and ensure that these sit alongside the accounts of our lives written by administrators, traders, historians and missionaries. Interdisciplinarity is operationalised in this thesis through the incorporation of knowledge from various disciplines and the implementation of a multi-disciplinary approach in the methodological framework. I will comment on the latter further below but let me discuss first another key concept that further consolidates this research in Pacific Studies—comparativity.

What I sought to do when I approached this thesis and why I did it under the realms of Pacific Studies is because my intention and purpose was not a simple-minded approach to contribute to the study of the Samoan language, but a contribution to knowledge about the geneaology of languages in the Pacific. This is because to me, ethnic specific research in Pacific Studies needs to inform and address the social, cultural, political, economic and religious contexts of what Hau'ofa (1993) calls "our sea of islands." What this does is it removes research from being nationalistic, ethnocentric or esoteric in nature. This is 
evident herein where I draw on the connections between the Samoan language and culture and Tahitian, Tongan, Tokelauan and Tuvaluan. I extend this to also include situations brought about through diasporic communities, thus extending the realms of what constitutes "the Pacific."

There are also methodological comparisons and analyses. The fa 'afaletui and corpus, as indigenous and social science methodologies respectively, are used both separately and in an integrated way. Separately, the fa'afaletui provides a culturally appropriate methodology that not only empowers indigenous perspectives, but one that offers a platform for critical and honest dialogue about changes to the gagana. The corpus methodology provides a platform for an empirical examination of the gagana. In addition, both methodologies value the oral discourse of Samoan indigenous culture and accommodate the written discourse introduced by Western cultures. Collectively, the methodologies are attentive to the interdisciplinarity and comparativity prescriptions raised by Teaiwa. Overall, the use of the fa 'afaletui and corpus provides an alternative to the customary rejection of the value(s) of social science methodologies by indigenous researchers (see Teaiwa 2009). The discourse comparison made between lāuga fa' 'amatai (chiefly speeches) and làuga fa'alelotu (sermons) through a diachronic and synchronic examination of foreign words, further acknowledges a commitment to comparative and indigenous analyses.

Empowering the voices of Pacific peoples is important and has been outlined above. The concept of empowerment in Pacific research is another significant parameter in Pacific Studies. I see empowerment in Pacific Studies as an approach and commitment to value and make more visible the histories of Pacific peoples. I acknowledge that the empowerment of indigenous voices is evident through local agency. We can understand and articulate local agency through the conditions (social, political and religious) which have shaped individual and collective agency against some aspects of change. In fact, the results of my study suggests that local agency has strengthened as more foreign concepts are being accommodated through the use of existing words.

Agency is also evident in the idea that religious transformation of Samoan society has not been a complete process. The incorporation of traditional rituals such as läuga in church is evidence of this. In addition, I acknowledge that in the post-modern era Samoans have become movers and shakers of change rather than being recipients or 
consequences of it. This is most evident when we think about transnationalism and diasporic settings where Samoans have become agents of language change. To summarise, the interdisciplinary, comparativity and empowerment elements of this thesis anchor it in the conceptual foundations of Pacific Studies.

\section{4) KEY CONCEPTS AND TERMS}

There are a number of key concepts and terms that underpin this research which require explanation.The Samoan terms for language and culture are gagana and aganu' $u$ which will be used throughout this thesis. The term $f a$ 'asämoa, which literally translates to the Samoan way of life, is used interchangebly with aganu' $u$.

The term Sāmoa, when used to refer to the name of the country, is spelt with the macron $\bar{a}$. By adding the macron $\overline{\mathrm{a}}$, it aligns with spoken Samoan. When used to refer to Samoans in general, such as the terms Samoan and Samoans, the macron $\bar{a}$ is omitted. The reason for this is to distinguish between the indigenous term Sāmoa and the foreign terms Samoan and Samoans.

The word lāuga, which refers to an oratorical speech, is used in the phrases lāuga fa 'amatai and läuga fa 'alelotu to distinguish between chiefly speeches and church sermons, respectively. The word Congregational and Lotu Ta 'iti are used interchangeably and refer to the independent denomination of the Congregational Christian Church of Sāmoa (CCCS).

Apart from proper nouns, such as chiefly titles and people and place names, the use of Pacific and Samoan words in this thesis have been italicised. A parenthesis translation is provided in the first use of a word. The translation in parenthesis, however, is omitted in all subsequent uses.

\section{5) CHAPTER OUTLINE}

There are seven chapters in this thesis. Chapter One introduces the research and provides discussions about Pacific Studies and Key Concepts and Terms.

Chapter Two is a synopsis of the relevant literatures examined for this study. These include the literatures on language contact and change, Pacific and Polynesian languages, the literature on Samoan language, culture and society including the literature on foreign missionisation and 
government arrival in Sāmoa. The research questions which have been drawn from the review of the literature conclude Chapter Two.

Chapter Three (Methodology) provides an analytical discussion and overview of the methodological underpinnings used for this study. The discussion looks at the two methodologies used (1) Fa'afaletui and (2) Corpus methodologies and provides information on corpus sampling, historical framework, text sources, compiling and coding. Information about the oral sources and semi-formal interviews are also provided. The chapter concludes with a discussion about the corpus and qualitative analysis of the findings.

Chapters Four and Five are presentations of the findings for the Fa'afaletui and Corpus, respectively. Chapter Six (Discussion) provides an articulation of the research findings. Chapter Seven (Conclusion) is structured as responses to the three research questions outlined in Chapter Two.

This Chapter has introduced the study as one which examines changes in the gagana Sāmoa. The next chapter provides a synopsis of the relevant literatures which this study draws from. 


\section{CHAPTER TWO}

\section{ILOILOGA 'O MAU TUSITUSIA}

(Literature Review)

\section{1) INTRODUCTION}

This research is based on a lexical and diachronic examination of changes to the gagana Sāmoa. The chapter reviews a range of literatures identified as relevant to the current topic. This review is divided into two main segments. The first segment, comprising of sections 2-10, examine the conceptual foundations for this research. The second segment looks at the literature on missionisation and government and the influences these institutions have had on the gagana. Both segments are central to the overall topic.

Sections 2 and 3 set the context for this research by exploring how languages come into contact and how these events can cause languages to change. This leads into a review of the existing literature about languages in the Pacific, Polynesian and gagana Sāmoa in sections 4, 5 and 6. The discussion in these sections position and explore the gagana Sāmoa as a Pacific and Austronesian language. Section 7 examines how the gagana reflects, and is situated, within Samoan society.

Sections 8, 9 and 10 introduce the concept of oratory as a domain where foreign influence on the lexicon has developed. Section 8 conceptualises oratory and its significance in the Pacific and to Samoan society. Sections 9 and 10 narrow the concept of oratory by focussing on the religious (lāuga fa' 'alelotu) and chiefly (lāuga fa' 'amatai) discourses. Each discourse is used as a representation of Christianity and government, respectively. Both Christianity and government are introduced institutions which have had significant influences on the gagana Sāmoa.

Sections 11-13 build on Christianity and government by reviewing the literature about foreign contact in Sāmoa (Section 11), particularly the missions (Section 12) and administrations (Section 13). These discussions begin with a brief review of mission and administration arrivals in Sāmoa but focus primarily on how the missions and administrations instigated and controlled language planning (Section 14), with emphasis on written orthography, in Sāmoa. Section 15 
reviews the literature on the impact of English on the gagana and provides a rationale for this research. Section 16 concludes this review by providing an overview of discussions, research gaps and how this research will contribute to the current literature. From the review of literatures, the chapter ends with the three research questions in section 2.18.

\section{2) LANGUAGE CONTACT}

The literature on language contact is extensive (Appel \& Muysken 1987; Dutton 1994; Hickey 2010; Thomason 2010; Trudgill 1986; Weinreich 1964; Winford \& Donald 2003). The literature deals with both spoken and written understandings of language and explores areas such as etymology, orthography and ecology. One of the significant themes in this body of literature is the conceptualisation that language contact is a prehistoric phenomenon and has existed since the beginning of the human race. Subsequently, it is through speaking communities that language contact arises. Further examination of this literature reflects the ideology that language(s) are a central phenomenon for human survival.

All human languages are communication systems constructed within the social environment of its speakers (Langacker 1967; Lynch 1998). Thus language is both a product of and a process enabling human interaction. Since time immemorial, human interaction has been characterised by population movements, motivated by personal, political and economic reasons. Population movement brings forth contact between cultures and languages. Today, it is unlikely that any living language has been exempted from contact with other languages and cultures.

Pacific peoples and their languages have been in contact for many centuries. Albert Wendt (1970, p. 52), for instance, comments on this idea:

"Like a tree a culture is forever growing new branches, foliage, and roots. Our cultures, contrary to the simplistic interpretation of our romantics, were changing even in prepapālagi [European] times through inter-island contact and the endeavours of exceptional individuals and groups who manipulated politics, religion, and other people...there is no state of cultural purity."

Cross-voyages between the people of Sāmoa, Fiji and Tonga, for instance, have led to the extensive sharing of cultures and vocabularies (Barnes \& Hunt 2005; Macpherson 2008). I have experienced this shared connectedness in the Samoan Studies classes I teach at Victoria University of Wellington Te Herenga Waka (VUW). In their pursuit to learn the gagana, non- 
Samoan students in particular, often reflect on the similarities between their own languages and cultures, such as Māori, Tongan, Fijian and Cook Island Māori, and the gagana. This reciprocation of linguistic and cultural worldviews was both disturbed and continued, however, with the arrival of foreigners to the Pacific.

Contact between Pacific peoples and foreigners led to the integration of many foreign words into the respective vocabularies. These included words from exogenous languages that were integrated into English, such as Dutch, French, German, American and Indian. In Fiji, for instance, the creation of Fijian-Hindi, a local variant of Hindi, eventuated from contact between the i-taukei, Fiji's indigenous people, and Indian labourers. The entry of European superpowers, such as the United States, Germany, Great Britain and France, to the Pacific region has lead to an enduring presence of foreign words in indigenous vocabularies (Biewer 2015). While Pacific cultures' contact with the Western world has been the main point here, ancient contact between indigenous peoples of the Pacific continued, however, through their work as teachers of the new religion (Christianity). In these endeavours, indigenous religious teachers introduced foreign words, which were associated with the Bible, to the cultures they came into contact with. Hovdhaugen's (1992) research about the influence of Samoan missionaries on the Tokelauan language, where innumerable amounts of Samoan words were introduced into the local vernacular, is evidence of this. In my capacity as a deacon, Sunday school teacher and choirmaster (see Section 1.2) in our local congregation, both the print (Samoan Bible, hymn books, church publications) and spoken (sermons, oratory, everyday conversations) mediums that we use to communicate in the gagana are laden with foreign words5.

Foreign ideologies, such as capitalism and employment, have led to the outward movement of Pacific peoples to metropolitan centres. The majority of my students, who are mainly third generation Samoan New Zealanders, have little to no knowledge of the gagana and aganu' $u$ (Samoan culture). As a result, most of our students begin learning the gagana as second language learners. These diasporic movements have intensified language, cultural contact and change (see Macpherson 2010). Today, most, if not all, Pacific languages have come into some form of contact with foreign languages at some point in time.

\footnotetext{
${ }^{5}$ See Chapter Five for a more comprehensive discussion of foreign terms
} 


\section{3) LANGUAGE CHANGE}

Whilst languages can remain largely unchanged for generations, language change is inevitable and can be steady or gradual (Aitchison 2001). Generally, there are two processes of language change: (1) internal and (2) external. Though I recognise that there are internal factors that might drive sound change, my focus in this research is on external change. Language change is caused by sustained periods of contact between speakers of different languages. (Aitchison 2001; Bauer 2006; Dutton 1994; Hickey 2001, 2012; Labov 1994; Langacker 1967, 1973; Macpherson 2010; Rensch 1994; Siegel 1992; Spolsky 2003; Tamasese 2013; Weinreich, Labov, \& Herzog 1968; Winford \& Donald 2003).

There are many domains that influence language change. These range from the supra-national organisations, such as the European Union, the state, regional or local governments, army, businesses, work, media, education, religion and the family (Spolsky 2012, p. 4). Each identifiable domain, Spolsky continues, has its typical insider informants, and each participant may have their own beliefs about language choice.

There are five main effects of language change. These are language shift, lexical borrowing (sound, grammar and vocabulary), cultural borrowing, creation of pidgin languages, and passive bilingualism (Dutton 1994, p. 194). Of the first, language shift (LS) occurs due to lengthy contact and influence with another language(s). LS is a process because there is a gradual move away from one language to another. It is also an outcome when the language in question is no longer used by members of the community (Pauwels 2016, p. 19). Contact and influence usually brings about lexical borrowings which also reflect cultural borrowing. The effects of language change is reflected more so with the creation of pidgins. A pidgin language is one created from two or more languages. This type of language is utilized by two speaking communities with prior linguistic distinctions as a bridging dialect. There are many pidgin languages in the Pacific which resulted from contact with Western languages. An example is the Papuan Pidgin English (PPE) that was developed initially from early trade jargon and which was used as a bridging language between English and the Papuan people (Muhlhausler 1996, p. 129). Within the dynamics of language, active and passive bilingualism becomes a characteristic of these communities. Through intense trade and intermarriage, for instance, the Chamorro language of Guam is characterised by an active and passive presence of Spanish, German, Japanese and English words (Muhlhausler 1996, p. 107). Because the interactions 
precede the changes, language change is, in fact, a consequence of a network of cultural, social and linguistic interactions.

The effects of language change can be perceived as either contributing to the contraction or expansion of a language (Macpherson 2010). The extinction of words, for instance, can be understood as language contraction, such as when missionaries banned the use of certain names, terms and concepts relating to entire areas of social practice. In contrast, where vocabulary extinction is offset with extensive borrowing, this can be thought of as a form of language expansion. Both lexical expansion and contraction are closely aligned to polysemy. Polysemy, a type of lexical change, for instance, is when languages encode new referents or alter the encoding of existing ones. Comment Brown and Witkowski (1983, p. 74), polysemy involves expanding a word for one referent to another when both bear a common meaning relation to one another. The effects of language change on the gagana have been considered enriching by some (Kamu 2008, p. 59; Ma'ia'i 2010, p. iii; Kruse-Vā‘ai 2011, p. 205) while detrimental by others (Ma'ilo 2016). From my own perspective, our gagana has been enriched and contracted for many decades. Both occur as the gagana adapts to societal change. As a people, our language mirrors local agency at all levels of the speech domain (family, village, district, government and diaspora) to preserve what we think is relevant and suitable to our contextual needs. Whether positive or negative, the reality is that the gagana remains exposed to continued lexical change.

The review of the current literature in sections two and three has signalled that language contact and change have transpired from individual and collective motivations for economic gain, religious conversion, political expansion and necessity resulting from technological innovation. The literature has also addressed the idea that it has been through human interactions that induced changes to languages have occurred. In the Pacific, social contact between Pacific peoples and Europeans resulted in an influx of foreign ideologies and vocabularies.

\section{4) PACIFIC LANGUAGES}

There is an overwhelming consensus in the literature about Pacific languages that draws attention to the notion that languages of the Pacific are diverse and consist of over fourteen hundred languages (Biewer, 2015; Crocombe, 2001; Drechsel, 2014; Lynch, 1998; Lynch, Ross, \& Crowley, 2002; Macpherson, 2010; Pawley, 2007; Pawley \& Green, 1973; Pawley \& 
Ross, 1995). Pawley's work is fascinating in this area because he finds that while some parts of the Pacific, such as Polynesia, are practically monolingual although they exhibit minor dialectal differences, in other parts, notably Melanesia and Micronesia, polylingualism is the norm (Pawley 2007, p. 1). The Polynesian Samoans, for example, are monolingual speakers. This contrasts with the linguistic situation of Papua New Guinea where over 900 languages are spoken. These language varieties have made the Pacific one of the most linguistically diverse regions in the world.

The Pacific's linguistic diversity is evidence of ancient networks of social contact which resulted in an extensive degree of lexical and cultural sharing (Keesing 1988; Bellwood 1996). Starks (2006, p. 377), for example, talks about how Samoans and Tongans settled in the North and South of Niue, resulting in dialectal differences between the Motu (North) and Tafiti (South) dialects. The arrival of foreigners, however, extended this sharing to encompass nonPacific words from languages such as English, French, Hebrew, Latin and American.

Relentless contact between the locals and foreigners became the platform for the creation of hybrid languages such as pidgin. Due to its significance in the colonial control of polylingual populations including the political stability required by capitalism, pidgin languages (see section 2.3), were created as both an informal and formal approach to communication (Crocombe 1976, p. 34; Siegel 1992, p. 65; Biewer 2015, p. 17). Pidgin Fijian or Pidgin Hindi, for instance, were developed and used as bridging dialects between Fijians and Indians of which became the language of interethnic communication (Lynch 1998, p. 264). Through time, pidgin languages were soon recognised as official languages because of their essential role in governance. Some, such as Hindi in Fiji, have become official languages. As a result, pidgin languages have become imprints of language contact and change in the Pacific.

\section{5) POLYNESIAN LANGUAGES}

What can the literatures regarding Pacific languages tell us about the languages of Polynesia, an area considered to be the last settled in the vast Pacific region? The immediate impression of the literature about Polynesians, such as Samoans, Tongans, Hawai'ians, Tūvaluans, Tokelauans, Tahitians, Cook Islanders and Māori (New Zealand), is that Polynesian peoples and their languages share cosmological, mythological, linguistic and cultural commonalities (Boissonnas 2014; Drechsel 2014; Elbert 1953; Geraghty 1995; Hollyman 1962; Ma 'ilo 2016; Otsuka 2005; Pawley 2007; Rensch 1994; Ritchie 1979; Tcherkézoff 2008; Turner 1861; 
Weisler 1998; Williamson 1967). Another impression is while most of the studies about Polynesian languages consider the correlations between language and society, the tendency in these literatures, however, has focussed primarily on the documentation of lexicons in the form of glossaries, grammar and history.

Compared to Micronesia and Melanesia, Polynesian languages are relatively homogenous. Despite minor lexical variations, the Samoan archipelago, consisting of Independent Sāmoa to the West and American Sāmoa, a territory of the United States of America, to the East, for instance, are linguistically homogenous (Freeman 1983, p. 117, Mosel and Hovdhaugen 1992, p. 8). Similar to the gagana, and despite having had distinctive languages spoken in the past in Manihiki, Mauke and Pukapuka, Cook Islanders now speak both Cook Island Maori (CIM) and Rarotongan (Maori) - two very similar lexicons (Biewer 2015, p. 17). Today, the linguistic foundations and idiosyncratic characteristics of Polynesian languages, such as Samoan, have remained monolingual.

\section{6) THE GAGANA SĀMOA}

One of the most telling characteristic of research about the gagana Sāmoa is the tendency for research to be either focussed on grammar (Hunkin ${ }^{63}$, 2009; Milner, 2012; Pawley 1966; Neffgen, 1918; Pratt, 1862) or on perception and observation (Hunkin-Tuiletufuga, 2001, 2012; Macpherson, 2010; Wilson, 2017). On the one hand, studies which have focussed on grammar have been largely motivated to accommodate learners of second languages, particularly in New Zealand where the Samoan language is the third most spoken language and where a Bachelor of Arts degree in Samoan Studies is offered at VUW. On the other, studies which have focussed on the perceptions and observations of the gagana have resulted in work looking at language loss (Amituana'i-Toloa, 2010; Wilson, 2010), language shift (Duranti, 1990; Mayer, 2001; Starks, 2006; Tualaulelei, 2008), and the need for the maintenance of the gagana in metropolitan centres where the gagana is a minority language struggling to exist in largely multi-lingual societies such as New Zealand, Australia and the United States mainland.

Other studies which have examined the gagana look at the use and impact of the gagana in areas such as indigenous reference (Suaali'i-Sāuni et al., 2014; Tamasese, 1994, 2003, 2005, 2008a, 2008b, 2011), ethnography (Kramer, 1995), law (Salevao, 2017), church (Kamu, 2008;

\footnotetext{
${ }^{6}$ Note that Hunkin and Hunkin-Tuiletufuga is the same author
} 
Lātai, 2015; Lesa, 2009; Muai'ava, 2011; Utumapu, 1998), policy (Spolsky, 1988, 2004), family environment (Wilson, 2010), film (McFarland-Tautau \& Hunkin, 2012; Muaiava \& Sua'ali'i-Sāuni, 2012; Purcell Sjölund, 2012), social identity (Kruse-Vā‘ai, 2011) and cultural arts (Duranti, 1983; Holmes, 1969; Mallon, 2018; Muai'ava, 2018). Though these studies and observations add much value to the literature on the gagana, a gap, however, is the disregard of more corpus-based empirical examinations and analyses of the gagana. One of the positive observations of the literature about the gagana, however, is the extensive coverage of the origins, history, grammar and indexes of the Samoan language.

The gagana has been described as the softest, the most polite and the most complete of all the Polynesian dialects (Danks 1984, p. 482). Samoans believe that the gagana is not a descendant of a proto language. Rather, oral history preserves the narrative that the gagana was gifted by Tagaloaalagi, Samoa's indigenous deity (Simanu 2012, p. 81). In contrast, linguistic science reveals an 8,000 year old language descendant (Gray et al. 2009, p. 479) of the Austronesian language family (Otsuko 2005, p. 13). Through contact with neighbouring civilisations, the gagana has become a parent language itself with its linguistic descendants being Tokelauan, Tuvaluan (Groube 1971, p. 278), East Futunan, Niuafo'ouan, and Pukapukan languages (Pawley 1966, p. 1; Tsukamoto 1988, p. 8; Mosel and Hovdhaugen 1992, p. 4). However, Groube (1971) also allows for the possibility that Samoans colonised and settled the same island nations. Whether the gagana was a gift or part of a linguistic lineage, both local and scientific versions should be interpreted as valid knowledge.

According to both local and scientific descriptions, the gagana is archaic (Pawley and Green 1973; Clark 2010); allusive and artistic (Holmes 1969); an inheritance (Tamasese 2011); and a symbol of identity (Hunkin-Tuiletufuga 2001). Like any language community, the gagana is also a site of cultural repository (Meleiseā 1978). Gagana links the present with the past, making it the lifeblood of Samoan culture (Tamasese 2005). Without gagana there is no culture, no custom, and no village (Fanaafi le Tagaloa 1996; Taua'à 2005). Even with the gagana, however, significant elements of the Samoan culture have disappeared and have been displaced by Christian religion. Despite this, the relationship between gagana and culture, therefore, is like oxygen to human survival. Without one, it is claimed, the other will not survive (HunkinTuiletufuga 2001). In essence, the gagana is central to the individual and collective identities of Samoans. 


\subsection{1) T-style \& $K$-style}

One of the most controlling factors in language choice is group membership. People choose or are made to choose, the language they use in different contexts (Fishman 1973, p. 68). In the gagana, there are various controlling factors that determine language choice.

Today there are two registers in the gagana. These are: (1) tautala lelei (t-style), and (2) tautala leaga (k-style) (Pratt 1862; Duranti 1990; Mosel and Hovdhaugen 1992; Hunkin 2009; Milner 2012). Tautala lelei and tautala leaga, literally meaning good talk and bad talk, are also referred to as formal and informal (colloquial and/or everyday) registers, respectively (Duranti 1990, p.4; Mosel and Hovdhaugen 1992). For instance, the informal pronunciation of the noun tapuā'iga (church service) is kapuā'iga. I bring to the attention of my students these register distinctions early on in our course. While this is not novel to some students, for others there is great bewilderment.

There are various arguments about the evolution of the t- and k-styles in the gagana. The first argument leans towards the idea that the t-style was Samoa's pre-Christian register (Milner 2012, p. xv). In favour of the first argument, the second argument posits the theory that the kstyle was a Tongan influence7. To clarify, while the Tongans use the letter $\mathrm{k}$, it is replaced in Samoan with the glottal stop. The final argument maintains that the missionaries' recording of the t- and k-styles were merely a reflection of what they heard and were not involved in crafting the language based on a religious or civilising agenda. In all of these arguments, there is overwhelming evidence to claim that the k-style may in fact have been a missionary influence when they introduced the letters $h, k$, and $r$ to accommodate foreign words in the gagana and to assist them in the construction of a written orthography (Horst 1986, p. vxi). This is where, in my opinion, the k-style was developed. I disagree with Milner's (1966, p. xv) account that foreigners' attempts to adopt the colloquial language was well-intended. In my opinion, the development of the k-style register was rather the product of a deliberate ploy to dismantle the local vernacular. The motive for this ploy was to elevate the new church discourse using the existing t-style while at the same time relegating, at least in comparison, Samoan rituals and practices through the use of the k-style. The motive was part of the overall push and consolidation of religious conversion in Sāmoa.

\footnotetext{
${ }^{7}$ See section 2.2 about Language contact in Polynesia
} 
The t- and k-style distinction became a decoy for the demotion of the local language and culture. To clarify, the missionaries assigned the pre-mission t-style register, which had precontact prestige to Samoans, to the church context. Therefore, Samoans had to speak in church using the t-style. By doing this, the language used in church became esteemed, revered and respected. Reverence of church language was enforced by print (see section 2.13) which was also in t-style. But the missionaries wanted to separate the non-secular from the secular. To do this, the k-style was allocated to cultural practices and rituals. Today, it is not uncommon to be met with disapproval when the use of these registers are interchanged by Samoan speakers. Samoans continue to consider colloquial pronunciation as being uncouth and vulgar (Milner 2012, p. xv).

However, the language practice does not always follow linguistic prescriptivism. In reality today, we find both the t- and k-styles being used in both church and cultural practices and rituals. Thus, there are signs that these forms of association are weakening. Nonetheless, the evolution of $\mathrm{t}$ - and k-styles is a significant part of the development and perceptions of the gagana in all facets of Samoan society. The influence of the missionaries on the language is discussed in more detail in section 2.13.

\subsection{2) Everyday, respectful \& chiefly gagana}

Samoans adjudge the gagana to consist of gagana 'o aso 'uma (everyday), gagana fa'aaloalo (respect) and gagana fa'amatai (chiefly) indexes (Simanu 2002, p. 77). Though seemingly separate, language categorisation tends to camouflage how fused these indexes actually are. Everyday vocabularies, for instance, are used in chiefly contexts, and increasingly frequently as matai titles are acquired by people with very restricted knowledge of the Samoan language. Chiefly language is regularly adored and practised in youth discourse. In addition, and although respect language is considered a must, increasingly people who do not hear the gagana fa'amatai regularly do not know it exists. These indexes are the heart of Samoan cultural expression (Tu'i 1987, p. 20).

Couched in allusion and allegory (Holmes 1969, Tu'i 1987; Schultz 2008; Tamasese 2008, 2011), gagana fa'aaloalo and fa'amatai are allusive varieties of the gagana. These characteristics originate from Samoans' appreciation and understanding of their society and culture (Tu'i 1987, p. 20). 
Gagana fa'aaloalo is used as a verbal lubricant (Freeman 1983, p. 123) to exhibit lagona fa'amaualalo (meekness). Lagona fa'amaualalo sanctions communication between tagata mātutua (elderly), matai (chiefs/orators), and fānau (children) (Simanu 2002, p. 77). An important aspect of gagana fa 'aaloalo is its application to others, rather than to oneself (Milner 2012, p. 298). Gagana fa'aaloalo, as Milner has suggested, developed out of the elaborate system of avoiding the hazard of insulting or lowering the dignity of a chief or guest in any way (Freeman 1983, p. 123).

Gagana fa 'amatai, is Samoans' ceremonial or pre-Christian language which honours matai and village culture and protocols (Fa'alafi 2005, p. 29). As Milner (2012) suggests, gagana ta'atele and gagana fa'aaloalo are the common property of all Samoans, whereas gagana fa 'amatai is the jealously guarded and esoteric stock-in-trade of matai. To use any other when addressing matai is equivalent to an insult (Pratt 1862, p. 39). The specialised registers of the gagana Sāmoa are used to administer and manage social relations. Table 1 demonstrates some lexical differences between the three varieties of the gagana:

Table 1:

Every day, respectful and chiefly language

\begin{tabular}{|c|c|c|}
\hline $\begin{array}{c}\text { GAGANA 'O } \\
\text { ASO } \\
\text { 'UMA }\end{array}$ & $\begin{array}{c}\text { GAGANA FA'AALOALO AND } \\
\text { FA'AMATAI }\end{array}$ & MEANING \\
\hline Ao o le Màlō & Ao o le Màlō, Tamà o le Atunu'u & Head of State \\
\hline $\operatorname{ali}^{6} i$ & tamāli'i, tapa'au, 'àiga & chief \\
\hline tūlāfale & tula, faiāā, fale 'upolu fetalaiga, tōfā & orator \\
\hline faletua & faletua & chief's/ clergy's wife \\
\hline tausi & tausi & orator's wife \\
\hline faife $a u$ & fa'afeagaiga, 'au'auna a le Atua & clergy \\
\hline palemia & Palemia & prime minister \\
\hline
\end{tabular}




\begin{tabular}{|l|l|c|}
\hline & $\begin{array}{l}\text { Ao o le Mālō: malelega } \\
\text { faife 'au: saunoaga }\end{array}$ & \\
ali i: saunoaga, tuleiga, tanoa & speech \\
& $\begin{array}{l}\text { tūlāfale: fetalaiga, vagana, utaga } \\
\text { faletua: saunoaga } \\
\text { tausi: fetalaiga } \\
\text { palemia: saunoaga }\end{array}$ & \\
\hline
\end{tabular}

As is shown in Table 1, respect terms can have multiple forms. Take, for instance, the word faife ' $a u$. It is not uncommon to hear faife 'au being referred to as sui va'aia 'o le Atua (image of God). In addition, there are denominational-specific appellations for faife 'au, such as fa 'afeagaiga taulagi (Congregational), tausi matāgaluega (Methodist) and ti 'ākono (Catholic). In some cases, therefore, respect words can be village-specific (Milner 2012, p. xv). The evolution of numerous respect terms was based on or can be attributed to an existence of terminologies specific to social historical events in certain villages and districts.

The development of multiple respect terms is also linked to the notion of avoidance (Milner 1961). As an example, some Samoan food names are also high chief or orator titles. The title Talo (taro) is another example. Talo, for instance, is a high orator title in the villages of Falease'elā (Talo'olevavau) and Satalo (Talo'olema'agao). In these villages, the term fuāuli is used for taro instead (see Milner 2012, p. 313). In addition, the title Tu'u'u of Si'umu district is also the name of the anemonefish species. Out of respect, the $\mathrm{Si}^{6}$ umu people use the term paleppo to refer to the anemonefish.

An important point about gagana 'o aso 'uma, gagana fa 'aaloalo and gagana fa 'amatai in Table 1 is that some terms do not change between index. The terms faletua and tausi are examples. In the case of the terms faletua and tausi, the main reason for this is that by remaining unchanged, the lower social ranking of women is maintained as the wives of ali ' $i$ and tüläfale. In addition, it may highlight the masculine contours of Samoan cultural practices and social roles.

Samoan respect terms have also transitioned to the Church context. The respect term to address the presence of a Congregational, Methodist and Catholic clergy member, for example, are Susūga, Afioga and Afioga, respectively. These respect terms are pre-Christian appelations for certain high chiefs. The lexical differences in denominational references to clergy were 
historically constructed. To illustrate, the clergy of the respective denominations were accorded the respect appellations of the paramount chiefs, Mālietoa, Lei'ataua, and Tuala, who accepted the respective denominations in Sāmoa. This is why the Congregational clergy are addressed Susūga after Mālietoa, the Methodist clergy addressed Afioga after Lei'ataua, and Catholic clergy are addressed Afioga after Tuala.

The gagana ta 'atele, fa 'aaloalo, and fa 'amatai registers have constantly stimulated Samoans creativity, imagination, pride, knowledge and command of the gagana (Meleiseā 1978, p. 98). Samoans have experimented, for instance, with each register interchangeably in all informal and formal social forms and hold village-specific words and cultures as creative and gratified aspects of their identities. The $s \bar{a}^{\prime} \bar{e}$, a pre-colonial wedding dance, and the $t u ' i \bar{e}$, a war chant, for instance, are pre-colonial practices unique to the villages of Salani and Manono (Tamasese 2008, 2005). The afí tunu 'o le Tupu, another ancient practice involving gifts of food baked in woven baskets and the performance of a journey by boat, is unique to the village of Sālelesi (Percival 2008). With distinct and shared vocabularies, these village practices continue to enable the nuanced articulation of Samoan worldviews (Tamasese 2011, p. 4).

\section{7) STRUCTURE OF SAMOAN SOCIETY}

Like all languages, the gagana is a mirror reflection of Samoan society. All aspects in Samoan society, such as hierarchy, gender, governance, religion, family, village, land, titles and indigenous knowledge have lexical representations. For a better understanding of the gagana, the following discussion examines the structure of Samoan society.

Samoan society is a stratified nation administered by titleholders who govern families and villages under the social-political system of the fa 'amatai (Freeman 1983, Tuimaleali'ifano 2006). Generally speaking, the fa'amatai consists of two types of matai: ali' $i$ (chief) and tūlāfale (orator). A third type of matai, known as (3) tūlāfale-ali 'i (chief-orator), is also part of the $f a$ 'amatai, however, not all villages have a tūlāfale-ali ' $i$ title.

All matai are chosen by the extended 'aiga (family). The selected individual embodies the name or title of the founding ancestor and becomes the trustee of the land owned by this ancestor and used by the family (Tcherkèzoff 2000, p. 116).

$A l i^{\complement} i$ and $t \bar{u} l a \bar{f}$ fale have differing roles. $A l i^{`} i$, the most select class (Turner 1984, p. 173), oversee and confer final decisions in the village council. In accordance with his particular lineage, ali $i$ 
are given various honours such as seating, 'ava sequence and foods (Kramer 1995, p. 658). Tülāfale, known as talking chiefs, advise ali'i on village matters and speak on their behalf (Meleiseā 1987, Meleiseā 1987, Va'ai 1999). When the circumstances befit, however, ali ' $i$ (chiefs) can also speak on their own behalf. The tüläfale-ali ' $i$ by which the holder combines the roles of the first two classes under both hats speak for themselves (Tuimaleali'ifano 2006, p. 2). Kramer (1995, p. 666) describes tüläfale-ali 'i as independent orators who came into existence through marriage to the daughters of tüläfale whose son inherited both names. However, Kramer's view of the origin of tüläfale-ali ' $i$ titles is weakened considering that some tūläfale-ali ' $i$ titles may have been created and bestowed by 'äiga. The roles of tüläfale are based on their cultural significance of being the tülaga-o-le-fale (house foundation) or a tula$o$-le-fale (the top beam of a house) (So‘o 2008, p. $217 \& 218$ ). These two meanings imply the social-political significance of tüläfale. As the primary instruments of traditional authority (Vā'ai 1999, p. 30), matai are looked upon as village role models who are responsible for maintaining peace and exemplifying ethical conduct.

There are other councils in a village under the council of matai. The wives of ali ' $i$ and tūlāfale have a council known as the fale 'o faletua ma tausi (house of faletua and tausi). Faletua are the wives of ali 'i. Tausi are the wives of tüläfale. The daughters and sons of ali' $i$ and tūlāfale also have what Meleiseā (p.7) calls corporate groups, as opposed to a council. They are known as fale 'o aualuma (unititled females) and fale 'o taulele' $a$ (untitled males). Each fale operates under the authority of the fale 'o matai (house of chiefs and orators). The fa'amatai is a complex hierarchical system that governs the everyday lives of Samoans.

Thus far, the literatures regarding the gagana have prioritised a research focus on ancient connections and contemporary influences on language. But in the overall make-up of the literature available, there is a lack of studies that examine the effects of ancient and contemporary influences on the practice of language use. One of these practices is lāuga (oratory/speeches).

\section{8) THE CONCEPT OF ORATORY}

As a concept, lāuga fa'amatai is an indigenous form of oratory which was embraced and became an integral ingredient in the establishment of the church in Sāmoa. The spiritual and cultural nuances of lāuga, for instance, were transferred to sermonry, and became known as lāuga fa'alelotu (church sermon). As will be conveyed in the subsequent sections, lāuga 
fa' 'amatai was also transferred into government, and became known as lāuga fa' 'a 'upufai 'o $m a \bar{l} \bar{o}$ (central-government discourse) where its practice became an integral aspect of government meetings and relations. The ideological differences between the phrases lāuga fa 'amatai and lāuga fa 'a 'upufai 'o mālō is discussed in more detail in section 3.7 of Chapter Three. This review analyses the literature on lāuga and how it is understood in the Pacific and Samoan societies.

\subsection{1) Oratory in the Pacific}

Oratory stems from oral traditions. Oral traditions are accumulated knowledge, constructed from stories, songs, myths, folktales, genealogies, poetry, proverbial expressions, riddles and rituals (UNESCO 1978, p. 22 \& 23). These traditions have been described as verbal libraries (Meleiseā 1978, p. 97) and tools of the past (Crocombe 2001, p. 47) for the purposes of recording indigenous histor[ies] (Tamasese 2005, p. 62). According to UNESCO (1978, p. 23), there are six types of oral traditions: (1) prose narrative, (2) poetry, (3) dramatic recitals, (4) genealogical recital, (5) riddles and (6) proverbs. A common characteristic in these areas is rhetoric and performance. Rhetoric is defined as a persuasive concept (Habinek 2005). Performance refers to artistic art (the doing of folklore) and artistic event (the performance situation) (Bauman 1977, p. 290). All are verbal or spoken art (Bauman 1977) and are constituents of Pacific oratory. Oratory in the Pacific is one of the most central and celebrated aspects of Pacific cultures.

According to Hardwicke (1896), oratory is the parent of liberty, power and the immortal and is an ancient practice in the Pacific. Oratory refers to public, ritual and ceremonial speechmaking (Duranti 1983; Habinek 2004). It signals status and is considered the passport to the supreme dominion of the state (Hardwicke 1896, p. 6). In many Pacific societies, such as Sāmoa, the greatest experts in oratory, known as failāuga, were often the greatest repositories of traditional knowledge (Meleiseā 1978, p. 97).

In oratory, the correct transmission of knowledge is paramount. Māori, the indigenous peoples of Aotearoa, for example, understood memory as a valuable skill that assured the correct transmission of knowledge to the observance of tapu (sacredness), mana (prestige) and mauri (aura or life force) (Murphy 2015, p. 108), a skill also found in knowledge transfer between Samoan people (Tamasese 2005, p. 63 \& 64). But the introduction of writing weakened 
memorization skills. Reflecting on the oral traditions of Manihiki, one of fifteen islands that comprise the Cook Islands archipelago, Kauraka (1991, p. 9) has this to say:

"Before the missionaries introduced writing, important knowledge had to be memorized. There was usually a person in each family assigned to memorize the genealogies of their lineage. The freezing of words on paper reduced the demand for such extensive memorization."

Writing has replaced verbal libraries and has contributed to the decline in the appreciation of oratory. Today, Samoans have become dependent on written materials for knowledge about Samoan customs and traditions. Writing has also stabilised, and in some ways, removes the dynamism or vitality experienced in spoken language. As a result, writing has become the 'authorised accounts'. The acquiring of knowledge through cultural observation and participation has also weakened. I have noted in section 2.6.1 the developments of how the tand k-style distinction carried over to the t-style as the formal way of writing. The highly specialised art of oratory has therefore become susceptible to change, particularly through the influence of foreign words.

\subsection{2) Samoan oratory}

The Samoan term for oratory is lāuga (Kramer 1995, p. 662). Lāuga is both a verb and a noun, emphasised in the phrases 'Ole 'a lāuga le tüläfale (the orator is about to perform a speech) and 'O le lāuga a le tūläfale (the orator's speech), respectively.

The term lāuga is comprised of the root word lau and the suffix - ga. Lau has many meanings in Samoan. These are: leaf, thatch, lip, brim of a cup, breadth, hundred, a particle used to count fish, a particle indicating uniformity or a blade of knife (Pratt 1862, p. 165 \& Milner 2012, p. 99). Missing from Pratt and Milner's definitions of lau, however, are the meanings wisdom and acknowledge. These meanings are very central to understanding lāuga.

As wisdom, lau means strand. Strand here refers to the wisdom of an ali 'i or tūlaffale. In the sentence 'aumai lau 'o lou finagalo (make known your wisdom), lau refers to a/the strand(s) of wisdom and knowledge of an elder. Seeking the knowledge and wisdom of an elder is the act of reaching out for prudence, insight and judgement through reflection, meditation, prayer, dialogue, experiment, practice, performance and observance (Tamasese 2009, p. 121). 
The wisdom of elders are the strand constituents that source lāuga. This is why lāuga is considered the practice of matai and elders (Tu'i 1987, p. 1) because the ability to speak well brings prestige to oneself and to one's family and village (Holmes 1969, p. 343). Also, Samoan oratory is a complex custom consisting of skilled or semi-skilled activities of village life, each of which has its own vocabulary reflecting the unique adaptation achieved by Samoans to their habitat (Milner 2012, p. xii). So as the seeds of the Samoan culture were being planted, lāuga flourished and became a vital fruit of its labour. So vital, lāuga is situated deeply within and pierces all layers of Samoan social relationships and interaction.

In Samoan society, lāuga is not just a speech, it is understood as a hereditary privilege (Crocombe 1976, p. 10), or what Samoans call tofi (inheritance) and fa'asinomaga (identity). The two different forms of lāuga will be discussed in Sections 2.9 and 2.10.

\section{9) LĀUGA FA'AMATAI: Chiefly speeches}

All lāuga are structured according to context (Duranti 1983). Lāuga fa'amatai are formal speeches performed by matai during Samoan rituals. These rituals include but are not limited to the 'ava 'o le feiloa 'iga ('ava ceremony), saofa 'i (title bestowment ceremony), fa 'aipoipoga (wedding ceremony), maliu (funeral), ta 'alolo (food presentations), fa' 'aulufalega (church and residence openings) and ifoga (reconciliation ritual).

It is important to note that läuga fa 'amatai is performed in both cultural rituals and church settings. As a result, and with the arrival of Christianity, läuga fa' amatai has been extended to the religious context of the lotu (Church). The use of läuga fa 'amatai in the lotu context is an extension of the $\mathrm{t}$ - and $\mathrm{k}$-style discussion provided in section 2.6.1.

\subsection{0) LĀUGA FA'ALELOTU: Sermons}

Läuga fa'alelotu, or sermons, became part of Samoan speeches soon after conversion to Christianity. Almost instantaneously, sermons became the stamp of both the clergy office and Pacific evangelization. By the mid 19th century, church sermons were being articulated vociferously in most if not all of Polynesia. Many parts of Melanesia and Micronesia were also fond of sermonism. 
With less difficulty than otherwise expected, Pacific peoples, especially men, who were charged with tasks of religious instruction, were discerned as ready-born preachers by the missionaries (Besnier 1995, p. 350). Teachers from Polynesia, for instance, were amazingly fond of preaching (Lange 2006, p. 296). In Sāmoa, the faife 'au (clergy) office was Samoanised. Their designated appellations (see Table 1) and gifts presented to them, for instance, resemble those of matai. The transfer of existing cultural aspects to the office of faife 'au also continued into sermonry where it is orated with the propriety of language and force of traditional lāuga (Lange 2006, p. 91). Indigenous customs, such as oratory, therefore, were easily transferable to the practice of Christianity.

Sermonry is a communicative and highly individualised practise (Besnier 1995, p. 345). In Samoan tapuā 'iga (church service), the lāuga is ascribed an independent ordering. The lāuga segment of the tapuā iga is usually the longest in duration. Other segments build towards the lāuga. The most central aspect of a lāuga fa'alelotu is what Besnier (1995, p. 344) calls the matua (core). The matua is the overall theme of a lāuga. Here, the relevance of biblical references deciphered during the Bible reading segment of the tapuā iga is orated.

\subsection{1) SPEECHES WITHIN SPEECHES}

There are lāuga within lāuga. Lāuga fa 'amatai can comprise of lāuga usu (host's speech), lāuga tali (visitor's reply speech), lāuga 'o le fa 'aipoipoga (wedding speech), lāuga 'o le maliu (funeral speech), lāuga 'o le saofa'i (title bestowment speech), lāuga 'o le ta'alolo (ta'alolo refers to the presentation of food), lāuga 'o le ifoga (ritual of reconciliation speech), and lāuga fa' 'afetai (gratitude speech). In addition, lāuga fa' 'alelotu can consist of lāuga a le faife 'au (sermon), lāuga a le ti 'äkono (deacon's speech), lāuga fa 'afetai (gratitude speech), lāuga 'o le fa'aulufalega (church inauguration speech), lāuga 'o le umusaga (residence inauguration speech) and others. In other contexts, such as the State, there are also lāuga, such as malelega or lāuga a le Ao 'o le Mãlō a Sāmoa (Head of State speech), lāuga a le Palemia (Prime Ministers speech), lāuga a le Fofoga Fetalai (House Speaker's speech) and lāuga a Minisitā (Minister's speech). These layers of lāuga demonstrate the complexities of lāuga in all its facets.

\subsection{2) DIFFERENCES BETWEEN THE TWO LĀUGA}


1. Writing: Unlike lāuga fa 'amatai, sermons or lāuga fa 'alelotu are read from paper. The expectation that lauga fa'amatai is orated from the mind or memorised prior, has remained despite the influence of literacy.

2. Non-negotiable: Because preaching, worship leading, teaching and pastoral care are all tasks of a pastor (Lange 2005, p. 58), the performance of läuga fa' 'alelotu is not negotiated in a fa' 'atau like lāuga fa' 'amatai' ${ }^{8}$. The absence of negotiation is due to the fact that all Samoan faife 'au, particularly Protestant ministers, have been selected by each congregation to be resident ministers in the village.

3. Tools: The lāuga fa 'amatai uses a to 'oto' o (staff) and fue (whisk). Normally, tūläfale deliver a läuga without a shirt. The tool for läuga fa' 'alelotu, however, is the Tusi Pa 'ia (Bible). Also, lāuga fa' 'alelotu are always performed with a suit and tie. The influence of missionaries on Pacific clothing is evident here (Crocombe 1976, p. 26).

4. Structure: lāuga fa'alelotu follows a Eurocentric structure based on liturgical conventions. Lāuga fa 'amatai is more comprehensive in structure. The structure of a lāuga fa' amatai consists of either four to seven parts. The folasaga (introduction) is comprised of metaphorical expressions relevant to the context. Orators will then recite village, church and government honorifics, depending on those present. Giving thanks to God is the next Section, called fa 'afetai, and is usually comprised of metaphors, biblical references and oral histories. This alludes to the extent to which indigneous worldviews and forms have been permeated by Christian ones and the two have become fused. Sermons, however, consist of three Sections, which are all connected to the biblical reading(s).

5. Vocabulary: Biblical citations characterise lāuga fa 'alelotu. Metaphors and proverbial sayings of ancient Sāmoa are used in lāuga fa'amatai. Both vocabulary sources, however, are used interchangeably.

\footnotetext{
${ }^{8}$ The full authority to perform a lāuga fa'alelotu is with the ordained pastor of the congregation. In terms of lay preachers in these congregations, who can lead a religious service, however, can only do so under the permission of the ordained pastor.
} 
It is through vocabulary choices that different lāuga are differentiated in written form. This will be discussed in more detail in the methodology chapter (section 3.8). To conclude this discussion on lāuga, Table 2 below provides the types of lāuga in both lāuga fa 'amatai and lāuga fa'alelotu discourses: 
Table 2:

$\underline{\text { Samoan Ceremonies and Lāuga Types }}$

\begin{tabular}{|c|c|c|c|}
\hline $\begin{array}{c}\text { Fa'amatai } \\
\text { Ceremonies }\end{array}$ & Lāuga Types & $\begin{array}{c}\text { Fa'alelotu } \\
\text { Ceremonies }\end{array}$ & Lāuga Types \\
\hline $\begin{array}{l}\text { 1. 'ava } \\
\text { (welcoming } \\
\text { ceremony) }\end{array}$ & $\begin{array}{l}\text { - opening speech } \\
\text { - closing speech }\end{array}$ & 1. Sāpati (worship) & - deacon speech \\
\hline $\begin{array}{l}\text { 2. maliu } \\
\text { (funeral) }\end{array}$ & $\begin{array}{l}\text { - gift presentations } \\
\text { - reply to gift } \\
\text { presentations }\end{array}$ & $\begin{array}{l}2 . \\
\text { tu'umālō/usufono }\end{array}$ & $\begin{array}{c}\text { - lāuga afiafi mo le } \\
\text { 'àiga } \\
\text { - lāuga i le lotu } \\
\text { fa 'ale ‘àiga } \\
\text { - lāuga i toe sauniga }\end{array}$ \\
\hline $\begin{array}{l}\text { 3. saofa } i \\
\text { (title bestowment) }\end{array}$ & $\begin{array}{l}\text { - opening speech } \\
\text { - closing speech }\end{array}$ & 3. saofa' $i$ & $\begin{array}{c}\text { - sermon for new title } \\
\text { holders }\end{array}$ \\
\hline $\begin{array}{l}\text { 4. fa'aulufalega } \\
\text { (opening convocation) }\end{array}$ & $\begin{array}{l}\text { - congregation speech } \\
\text { - guests speech }\end{array}$ & 4. fa'aulufalega & $\begin{array}{c}\text { - chapel induction } \\
\text { sermon }\end{array}$ \\
\hline $\begin{array}{l}\text { 5. umusaga } \\
\text { (opening of a chief's } \\
\text { residence) }\end{array}$ & $\begin{array}{c}\text { - family speech for the } \\
\text { house builders and } \\
\text { village }\end{array}$ & 5. uтияaga & $\begin{array}{c}\text { - sermon for resident } \\
\text { induction }\end{array}$ \\
\hline $\begin{array}{l}\text { 6. fono a le пи' } и \\
\text { (village meeting) }\end{array}$ & $\begin{array}{c}\text { - opening speech } \\
\text { - intra-village speeches }\end{array}$ & $\begin{array}{l}\text { 6. fono a le } \\
\text { ekalesia } \\
\text { (church meeting) }\end{array}$ & - meeting speeches \\
\hline $\begin{array}{l}\text { 7. ifoga } \\
\text { (reconciliation events) }\end{array}$ & $\begin{array}{l}\text { - offender's family } \\
\text { speech } \\
\text { - victim's family speech }\end{array}$ & $\begin{array}{l}\text { 7.papatisoga } \\
\text { (baptism/eucharist) }\end{array}$ & $\begin{array}{l}\text { - Eucharist } \\
\text { - baptism }\end{array}$ \\
\hline $\begin{array}{l}\text { 8. fa 'aipoipoga } \\
\text { (weddings) }\end{array}$ & $\begin{array}{l}\text { - lāuga 'o si'i alofa } \\
\text { - lāuga a 'āiga na lua } \\
\text { - lāuga a le vala'aulia }\end{array}$ & 8. fa 'aipoipoga & - wedding sermon \\
\hline
\end{tabular}


Though the literature has examined lāuga, church and government (Boyd 1968; Duranti 1983; Duranti 1992a, 1992b; Holmes 1969; Kruse-Vā‘ai 2011; Lange 2006; Meleiseā Meleiseā, \& Meleiseā 2012; Meleiseā 1987a, 1987b; Meleiseā \& Schoeffel 2017; So‘o 2008; Tui 1987), these have largely been discussed in isolation from each other. There are currently no studies that examine the influences of the church and government on the gagana through a conceptualisation of lāuga. But how influential was the church and government in Sāmoa? This question is looked at in the next sections $(2.11-2.14)$ which review the literatures regarding foreign contact in Sāmoa.

\subsection{3) FOREIGN CONTACT IN SĀMOA}

The most discussed matter in the literature regarding foreign contact in Sāmoa has been about the arrival and influence of church and central government (Field 2006; Hugh 1978; Kamu 2008; Lange 2006; Liua'ana 1997; Ma 'ilo 2016; Meleiseā et al., 2012; Meleiseā 1987a, 1987b, 1992; Meleiseā, Meleiseā, Vā‘ai \& Suafole, 2017; Meleiseā \& Schoeffel 2017; Schoeffel 1995; So`o 2012; Tanielu 1968; Tom 1986; Vito 2011).

According to the literature, foreign contact in Sāmoa is significant because of the effects it had, and continues to have, on areas such as language (Ma'ilo 2016), society (Field 2006), politics (Meleiseā 1987a; So‘o 2008), religion (Lange 2006; Tuimaualuga 1977), labourers (Liua'ana 1997; Tom 1986) and health (Akeli 2017; Boyd 1980; McLane 2014; Tomkins 1992). These studies are valuable in understanding the influence of foreign contact and ideologies in Sāmoa. The ensuing review examines foreign contact in two ways: (1) the arrival of church and government and (2) how these institutions influenced language planning.

From the very beginning, Samoans were never an isolated or sedentary race. Foreign contact in Sāmoa began in prehistoric times with contact with non-Samoans from the Tongan, Fijian, Uvea and Futuna archipelagos. From these inter-island contacts, cultures, languages, and genealogies were shared and changed (Macpherson 2010, p. 592). This Section, however, focusses on the European contact in Sāmoa, which began in the mid-18th century.

Early encounters between Samoans and papālagi were immediate but limited (Gilson 1970). It is recorded that the first Europeans to sight Sāmoa were Dutch explorer Jacob Roggewein in 1722 and French navigator Louis Antoine de Bougainville in 1768. The first expedition to set foot on Samoan land was the Lapérouse expedition in 1787 (Ellison 1938, p. 18 \& 19). It was 
a period of extreme interest, particularly towards the physical appearances, material possessions and linguistic differences of the other (Kramer 1865, p. 14). These social and physical exchanges became the first events of social, physical and linguistic exchanges.

Europeans are described as having burst from the heavens (Gilson 1970, p. 65). Samoans captured this moment by coining the word papālagi, which means to burst ( $p a / p \bar{a})$ from (mai) heaven (lagi) (Turner 1984, p. 199). In Samoan mythology, lagi is a sacred place. It was a place where Samoa's indigenous deity Tagaloaalagi resided. Anyone from lagi was thus revered. Matai (chiefs) are said to have derived from lagi and as descendants of a higher power, they were made leaders of families, villages and the nation. As they were considered to have come from lagi, papālagi were instantly respected. These social and lexical correlations from Samoan and European contact marked the beginning of Samoans' social transformation.

Papālagi arrived in Sāmoa in three waves. These are the C-triumvirate of Christianity, Colonialism and Capitalism (Rakuita 2014, p. 160 \& 161). The C-triumvirate waves were brought to Sāmoa by Europeans in the form of beachcombers and convicts (Gilson 1970, p. 65); explorers, traders, whalers (Pomeroy 1970; Lloyd 1996) missionaries and consuls (Meleiseā 1987). Samoans' beliefs about papālagi celestial origins validated what they brought with them.

Though small in numbers, beachcombers and convicts acculturated to the Samoan way of life and began to learn and speak the gagana (Tcherkezoff and Douaire-Marsaudon 2005). Some became very fluent, particularly through marriage to Samoan women.

The arrival of explorers, traders and whalers were motivated by economic reasons and financial gain (Pomeroy 1951; Lloyd 1996) ${ }^{9}$. Though cautious to begin with, trading became characteristic of these early relations. Fruits, shells, fishhooks, mats, chickens, sultana birds, pigs, pigeons, dogs, glass beads and spears, for instance, were exchanged (Kramer 1865, p. 8, 9-11). Social interaction between Samoans and foreigners was gaining momentum.

But it was not until the early $19^{\text {th }}$ century that the third, and most formidable, wave of papālagi arrived in Sāmoa in the form of the missionary and consuls. The arrival of foreign missions to Sāmoa was no accident. It transpired from the desire for denominational growth, particularly

\footnotetext{
${ }^{9}$ The most notable explorers and traders to arrive in Sāmoa were Dutchman Jacob Roggewein and his crew in 1722, French explorers Louis de Bougainville and John Francis Galaup de la Perouse in 1768 and 1787, and the H.M.S. Pandora in 1790 Gilson, R. P. (1970). Sāmoa 1830 to 1900: The Politics of a Multi-Cultural Community. London, Oxford University Press.
} 
by reformed Protestants in Europe. Soon after, world evangelisation, considered to be the most influential in the history of mankind, fixated on the Pacific, as it did in other parts of the world. It arrived to Sāmoa in 1830.

Seventy years later, representatives of the first of two foreign administrations anchored in Sāmoa. They were the Germans from 1900-1914 and the New Zealand administration from 1914-1962. Multi-national claims for Samoan land led to the great power rivalry between the Germans, English and Americans (Lang 2002, p. 24). The Americans wanted the eastern islands of Tutuila and Manu'a because the harbour at Pago Pago (in Tutuila) was identified as a potential naval base. The Germans, on the other hand, viewed the western islands ('Upolu \& Savai'i) as a location for settlement and entrepreneurship (Meleiseā 1987; Davidson 2012). The signing and ratification of the Treaty of Berlin in 1899 and 1900 between Germany, the United States and Britain, appropriated western Sāmoa under Germany and eastern Sāmoa to the United States.

When the League of Nations allocated mandates for former German territories at the start of the war, German Sāmoa became British Sāmoa in 1914 under the League of Nations mandate class C. Class $\mathrm{C}$ mandates were territories identified as having no prospect for independence (Myers 1921). The Samoan mandate, therefore, was designed to promote the material, moral well-being and social progress of the inhabitants of the territory (Akeli 2017, p. 368) while being politically dependent. The British government allocated the administration of German Sāmoa to the Dominion of New Zealand. Arriving in 1914, the New Zealand administration (NZA) conserved many German administrative foundations.

The three waves of papālagi arrival caused immense changes to the Samoan culture, religion, governance, and way of life. But it was language where they made the most impact. The missions and consuls influenced the language in two ways: (1) status and (2) corpus planning.

\subsection{4) STATUS AND CORPUS PLANNING}

Status planning refers to deliberate efforts to influence the allocation of functions among a community's languages (Cooper 1989, p. 99). It is an activity intended to promote systematic linguistic change in some community of speakers. Reasons for planning languages are based on intentions to maintain civil order and communication, and to move the entire society in some direction deemed good or useful by government (Kaplan 2013, p. 2). Corpus planning is 
the deliberate efforts to determine the way a language is written (Cooper 1989, p. $99 \& 122$ ). Mission decisions regarding language matters, for instance, tended to be ad hoc and local, aimed at achieving local goals such as facilitating preaching, education or preparing Bible translations (Muhlhausler 1996, p. 139). The translation of the Bible to Samoan in 1849, therefore, is an example of corpus planning. Both status and corpus planning are conducted to influence and control the acquisition of a language, usually the dominant and foreign language.

Status and corpus language planning is directed by the promulgation of language policies (Kaplan 2013, p. 2). Language policy is a body of ideas, laws, regulations, rules and practices intended to achieve the planned language change (Kaplan 2013 p. 2). One of the consequences of language policies, whether deliberate or unintended, is they may cripple indigenous languages. This creates the levelling of diversity and the introduction of a single system for nationalistic, religious and economic reasons (Hunkin and Meyer 2006, p. 64). This was because linguistic diversity and multiplicity was seen as a costly situation to manage and an outright disaster to the outside observer (Muhlhausler 1987, p. 3). In American Sāmoa, for instance, the translation of educational resources into the vernacular was deemed costly in time and a handicap to learning English (Baldauf \& Luke 1990, p. 266). This created the levelling of diversity and the introduction of a single system for nationalistic, religious and economic reasons (Hunkin \& Meyer 2006, p. 64). Therefore, the decision not to use Samoan could be a potential contributor to $\mathrm{LS}^{10}$ (see the consequences of language change in section 2.3). In Sāmoa, language planning was organised by the missions and government.

\subsection{5) MISSIONS AND LANGUAGE}

To date, there has been no review of the influences of the missions on the construction of a written orthography during their time in Sāmoa. Much of the literature deals with the adverse effects of the missions on the local vernacular and culture as opposed to language planning. Perhaps the most comprehensive of these studies to date is Ma'ilo's (2016) manuscript titled Bible-ing my Samoan, where he critically examines the damaging influences of the missions on the gagana and culture of Sāmoa through their translation of the Bible. This review brings together various discussions about how the missions organised the language, through status and corpus planning initiatives.

\footnotetext{
${ }^{10}$ language shift
} 
News of Christianity preceded the missionaries to Sāmoa because Samoans had heard from Methodist Tongan teachers about evangelisation back home. The arrival of the missionaries to Sāmoa, therefore, was anticipated. In their articulation of missionary contact, Samoans interpreted it as the fulfilment of an ancient prophecy made by Nafanua, an ancient wargoddess, who prophesised the arrival of a heavenly government. Samoans' reverence of Nafanua's prophecy was demonstrated in their response to the new doctrine when within a decade the entire nation had converted to Christianity.

Samoan conversion worked in the missionaries' favour as their objective was to conquer the souls and minds of the locals (Lynch 1998, p. 207). Though they were only just beginning to make sense of the doctrine, Samoans were quick to dislodge their indigenous pantheons (Retzlaff 2016, p. 17). Revered demi-gods, such as some bird and fish kinds, became sustenance. Sacred worship sites, such as the Fale 'o le Fe' $e$ (the house of the octopus) (Freeman 1944), were demolished and replaced by church buildings (Turner 1984). Cultural rituals were either Christianised or stopped. These developments were the beginning of gagana and cultural transformation.

Written orthography played an influential role in transforming the Samoan psyche. A view held by Westerners of the time was the idea that the print language:

"is more controllable and can be monitored by schools, editors, publishers, and/or governmental review boards. The written language often has, or develops, an identifiable standard to which it can be compared and held. Writing is a more consciously deliberate activity than speaking and therefore there is more self-correction in writing and therefore, more of a possibility of replacing the spontaneous and informal spoken language by a more educated variety of the language (Fishman 2006, p. 6 \& 7).

As a result, the English alphabet was introduced much to the amazement of the locals. Using the English alphabet as a template, the LMS missionaries constructed the first $P^{-11}$ (Samoan alphabet) consisting of five vaueli (vowels) and twelve konesane (consonants). However, the missionaries quickly realised that the vernacular resisted foreign transliterations (phonology). Because of this, the consonants $h, k$, and $r$ were added to accommodate what they considered were lexical deficiencies. These alphabets became the foundation for language planning.

\footnotetext{
${ }^{11}$ The term $P \bar{l}$ is a Tahitian word for alphabet (Wahlroos 2002, p. 3). The term seems to be borrowed into Samoan.
} 
The construction of the Samoan alphabet was also based on the realisation that the Bible had to be translated into Samoan. To do this, the Samoan language had to become a written language as well as an oral language (Salesa, 2014).

Language planning intensified as the production of written materials in Samoan and English multiplied. By 1834, four years after missionary arrival in Sāmoa, the first book in Samoan titled $E$ Tala A, E, F, was printed at the Mission Press in Huahine (Mosel and Hovdhaugen 1992, p. 6). By 1837, 20,000 copies of books in Samoan were distributed and accompanied by English translations. Though these texts were significant, it was the translation of the Tusi Pa 'ia (Bible) to Samoan that amplified language decisions and its influence on the local population.

A lot of language decisions were made in the translation process. One of the decisions was the use of the Tahitian Bible in the translation of the Bible to Samoan. As a result, many Tahitian words were borrowed such as purera ' $a$ (meaning altar but spelled as pulela' $a$ in Samoan), 'api (meaning book and also spelled 'api in Samoan) and ruto (wolf spelled luko in Samoan) (Wahlroos 2002). In addition, the missionaries, for instance, were convinced that the vernacular and culture were heathen and needed to be ethically quarantined to satisfy Christian principles (Topping 1987; Ma'ilo 2016). As an example, the missionaries disapproved of the virginity culture and excessive gifting aspects of nunuavaga (Samoan pre-Christianity wedding ceremony). Though the missionaries could not remove gifting, they were successful in abolishing the virginity culture along with tini (marriage songs) (Moyle 1975, p. 230). They also renamed nunuavaga fa'aipoipoga, a term they borrowed from the Tahitian Bible. The paganising of some gagana and aganu' $u$ created a culture of guilt and shame, particularly around notions of sexuality (Suaali“i-Sāuni 2014). Missionaries’ priorities to redress the vernacular during the translation of the Bible caused poetic injury to the gagana and aganu' $u$ (Fanaafi le Tagaloa 1996; Lynch, Ross et al. 2002; Hunkin and Meyer 2006). The translation of the Tusi Pa'ia, therefore, I consider as one of the most deliberate and pivotal events of language change (Spolsky 2003, p. 82). From that point forward, the gagana was used as a vehicle of change.

\subsection{1) Literacy in the gagana}

Literacy in the gagana was a missionary language policy in Sāmoa (Baldauf and Luke 1990, p. 263). Indigenous communities, like the Samoans, believed that adeptness in reading and writing was the key to acquiring the tangible resources of the missions (Parsonson 1967, p. 57). 
It lead to what Meleiseā (1987, p. 147) describes as a revolution of aspiration. For the missionaries, this was favourable because a literate population would assist in Samoans' understanding of Christianity. By 1900, a minority of Samoans were bilingually literate (Mosel \& Hovdhaugen 1992, p. 7). When the control of Mālua and other theological institutions was passed to Samoans, the need for bilingualism decreased, mainly because instruction was predominantly in Samoan and to the extent that it became necessary in the creation of a public service. To be able to do this using the vernacular excited the missionaries. But they needed to find ways to make gagana literacy happen.

Almost immediately after the arrival of the missions in the mid-19th century, literacy in Sāmoa was institutionalised through the establishment of firstly faife 'au schools and later government schools. In these schools, acquisition planning took an observational approach to teaching language. That is, Samoans learned English and Samoan through what Foster-Cohen (2009, p. 3) describes as observation, imitation, pattern extraction and adjustment.

All mission schools focussed on religious education but had space in the curriculum to teach secular subjects such as arithmetic, reading and writing (New Zealand Department of Island Territories 1951, p. 94). Using both English and Samoan, language use in schools was deliberate. English was the language of the mission so it was utilised as the superior form. The educational system that developed in Sāmoa allocated the local vernacular at the lower grades and English at the higher levels of the curriculum. All educational institutions did two things: (1) propagated a particular brand or faith (Narokobi 1981, p. 139); and (2) became vehicles for the expression of English (Anae 2002, p. 154). Today, language in education is a form of imposition and manipulation of language policy because it is used by authorities to turn ideology into practice (Shohamy 2005, p. 76). What this did was elevate English as the language of prestige (Baldauf \& Luke 1990, p. 264).

Since their arrival, the missions initiated corpus and status planning in Sāmoa. Their decisions about language were based on ethical suitability for the new doctrine, much to the detriment of the vernacular. It was also based on the preconception that the gagana was heathen and inferior. But they were not the only foreigners to think this way or influence the gagana in drastic fashion.

\subsection{6) FOREIGN ADMINISTRATIONS AND LANGUAGE}


There is currently no single documentation of the language planning initiatives implemented by foreign administrations in Sāmoa. There are, however, brief commentaries regarding the language policies of Germany (Baldauf \& Luke 1990; Conrad 2012; Stohlberg 2015) and the NZA (New Zealand Executive Council 1920; New Zealand Department of Island Territories 1951; Biewer 2015). As a result, the following review of these literatures attempts to integrate these into one discussion.

\subsection{1) German administration and language}

German administration of Sāmoa was based on a form of colonisation which negotiated rather than oppressed through force. They co-operated with indigenous structures rather than replaced them immediately (Lang 2002, p. 12). The German ambassador to Sāmoa, Dr. Wilhem Solf, for instance, adopted the expedient of ruling through existing institutions (Boyd 1968, p. 150) where he based social interactions with the locals on fa' asāmoa (Samoan traditions) (e.g. kavadrinking) (Conrad 2012, p. 121). By using fa 'asāmoa, the Germans got along well with people, including the missions (Thomas 1984, p. 221). German approaches to governance in Sāmoa resulted in good social relations in most cases.

Amicable social relations extended to language use and teaching. As the official language of German Sāmoa was German, the LMS included German language classes as part of their secular curriculum. The Methodists and Catholics also taught German classes (Stolberg 2013, p. 331). Ifiifi, a German established school that aimed at the educational preparation of European and part-Samoan children for government employment, provided the most comprehensive of German language classes (Baldauf \& Luke 1990, p. 270). But wishes to make German a national language were hindered by their own policy. It was a general German policy in all its colonies to use a prescribed list of only 150 words for locals and non-German Europeans to learn (Conrad 2012, p. 117). The Germans feared that non-Germans' competency in the German language would be a threat to German status. As a result, not many people became fluent in German. Germans themselves spoke English to each other, also. Therefore, the German language never superceded the dominance of the other colonial language, English, which was strongly linked to the work of the missions. It also resulted in the non-existence of a German Sāmoa variety, comprising of Samoan and German words which transpired in other German mandate territories in the Pacific (Stolberg 2013). The defeat of the dual alliance of Germany, Austria and Hungary to the Triple Entente coalition of France, Russia and Great 
Britain in 1918 lead to the military takeover of Sāmoa by the New Zealand forces. The departure of the Germans led to the decline and loss of any potentially significant German language influence on the vernacular.

The defeat of the dual alliance of Germany, Austria and Hungary to the Triple Entente coalition of France, Russia and Great Britain in 1918 lead to the military takeover of Sāmoa by the NZA under British decree. The departure of the Germans led to the decline and loss of any potentially significant German language influence on the vernacular.

\subsection{2) New Zealand administration}

New Zealand's administration of Sāmoa is best described as paternalistic, and one which was characterised by colonial legislation used to control the local population on the one hand, and resistance movements, boycotts and petitions by the locals on the other. Unlike the Germans who governed Sāmoa in the interests of peace, order and economic prosperity (Lauofo \& Meredith 2002, p. 7), the NZA, in contrast, imposed proclamations. These included prohibitions on communication (with Germans), public meetings, print media, property take over (land, possessions [guns and automobiles]), curfews, and liquor consumption (Meleiseā 1987, p. 127 \& 128). Another piece of legislation was the Sāmoa Offenders Ordinance of 1922 which was formulated to oppress the locals and give the NZA the power to revoke chiefly titles and banish Samoans (Denoon \& Meleiseā 1997, p. 258). They had the authority to do so because the League of Nations mandate of German Sāmoa designated full power of administration and legislation to the Dominion of New Zealand (https://nzhistory.govt.nz). Though the mandate pushed for local liberation, the mandate governments acted much as they pleased (Denoon \& Meleiseā 1997, p. 232). This idea of isolation and separation was a tool used to extinguish Samoans' wishes for representation in governance.

Moreover, when the NZA ignored quarantine measures for the influenza infected Talune from New Zealand, which killed 22\% of the population (Tomkins 1992, p. 181), Samoans had had enough. Even local Europeans were annoyed by the restrictions and petty tyrannies of military government (Boyd 1968, p. 162). Samoans and local Europeans' dissatisfaction with the administration led to a combined national resistance. A series of social resistance and petitions were made (Boyd 1968). Peaceful resistance movements such as the Mau (People's Independence) in 1926, the Samoan petition of 9 March in 1928 to the League of Nations and the Toea'ina Club, a local trading company established to operate against exploitative traders 
(Couper 2009, p. 154), were three of many national demonstrations against the NZA. In 1946, Samoans petitioned the United Nations requesting self-governance (Boyd 1968, p. 164). As a result, a Trusteeship Agreement was approved by the General Assembly of the United Nations and New Zealand formally committed itself to promote the development of the Territory towards ultimate self-government (New Zealand Department of Island Territories 1951, p. 12).

\subsection{3) New Zealand administration and language}

Language was used as a controlling mechanism during NZA and Trusteeship periods in Sāmoa. NZA controlled and monitored language through legislation and education. In government, written documents were to be bilingual, but with contrasting objectives. In the Sāmoa Act of 1921, published by the New Zealand government, it states:

"Every Ordinance may be passed either in the English language alone, or both in the English language and in the Native language of Samoa; but if, in the latter case, there is any conflict between the English and the Native version of the Ordinance, the English version shall prevail” (Executive Council of New Zealand 1920, p. 18).

The prevalence of English over the gagana in government ordinances and documents was deemed cost-effective to the development of the nation (Biewer 2015, p. $23 \& 24$ ). To ensure that the population had access to government decisions, all ordinances, regulations, Orders in Council, proclamations, warrants, appointments and acts relative to the government of Sāmoa were published in the Western Sāmoa Gazette (Executive Council of New Zealand 1920, p. 18). As mentioned in Section 2.13, print form was a key instrument in corpus and status language planning in Sāmoa.

In education, the NZA was legislatively permitted to establish and maintain public schools in Sāmoa as deemed necessary for the education of the Samoan or other inhabitants thereof (Executive Council of New Zealand 1920, p. 16). The purpose of colonial schools (and missionary schools), particularly at the secondary level, was to train individuals to fill higher positions in the State (New Zealand Department of Island Territories 1951, p. 99; Tamasese 2005, p. 41), as had been the practice during German administration.

The use of language in schools was to promote bilingualism, with greater emphasis on learning English: 
"The policy regarding the teaching of language is to make it possible for all Samoans to become bilingual, with the English language as their second tongue. Those pupils who speak only Samoan and come from Samoan-speaking homes commence their learning in the vernacular. In the junior classes a steadily increasing amount of English is taught until at about the Standard 4 or Form 1 level it is possible for the pupils to do all their learning in English. In the senior classes of the primary schools all teaching is in English, though the Samoan language is retained as a subject. Children from Englishspeaking homes do all their learning in English, but may have Samoan language as a subject. The amount and quality of English taught is largely determined by the proficiency of the Samoan teachers in that language. As yet a great number of them are not fluent in English” (New Zealand Department of Island Territories 1951, p. 98).

But the signing of the Trusteeship agreement as a pathway for self-governance altered the way the gagana was viewed, at least by the government. It later states that the NZA encouraged the advancement of instruction in the gagana in schools:

"The Council, noting that the new Samoan Dictionary will shortly be published, and, bearing in mind that the Samoan language may become the official language of the new State, emphasises the importance of advanced instruction in that language in the schools and of the provision for further literature in Samoan" (New Zealand Department of Island Territories 1951, p. 113).

NZA was also supportive of the fostering of the gagana through indigenous arts and crafts in the form of Samoan songs, dances and the various types of handicraft (New Zealand Department of Island Territories 1951, p. 103). Furthermore, it is stated that:

"In June 1959, approximately 70,000 pounds was aided by the New Zealand government to improve education in the Territory. One area they wanted to improve was the increase in the provision of publications and textbooks. As a result, 6,300 pounds was appropriated for publications and textbooks, while two text-books writers visited Samoa and began work on textbooks in simple English. The preparation of textbooks in Samoan was also put in hand" (New Zealand Department of Island Territories 1951, p. 97).

But while the government was supportive of the advancement of the gagana, there were also accounts of abuse towards those who spoke the gagana in schools: 
"We were put on detention for speaking Samoan, and sent to the school's banana plantation, where we would engage in labouring work for two hours after school. English was the order of the day and lingua franca at all times" (Silipa 2004, p. 285).

According to Silipa (2004, p. 284), a policy was imposed by the New Zealand superintendent in 1954 where primary educational lessons were to be presented in English on the Samoan radio. In this light, Kenix $(2015$, p. 554) comments on the idea that the media (Samoan radio in this case), is a medium where a national identity can be created which is usually done through the exclusion and inclusion of people. These cases are heard of in anecdotal accounts, but not much has been documented.

In all, the Church and State dethroned many aspects of the indigenous epistemology and pedagogy. Language played an important function in these processes. Literacy introduced a new form of pedagogy. By the mid- $19^{\text {th }}$ century, the aganu' $u$ and gagana were immersed with the language of the Bible. The State imposed its own influence on the gagana when it arrived in 1900. Both Christianity and the State became the main agents of transformation in Sāmoa and the Pacific as a whole (Parsonson 1967; Topping 1987; Muhlhausler 1990; Crowley 2000). The question that arises, therefore, is what has been the extent of the impact of English on the gagana as a result of Church and government influence? Section 2.17 reviews existing literatures that study these impacts.

\subsection{7) THE IMPACT OF ENGLISH ON THE GAGANA}

Work that examines the gagana comments on the impacts of foreign languages on the gagana, as opposed to specific foreign language influences. Nonetheless, the effects of English on the gagana are considerable (Pratt 1862; Cain 1986; Mosel \& Hovdhaugen 1992; Allardice 2000; Lāmeta 2005; Tamasese 2005; Ma‘ia'i 2010; Macpherson 2010; Kruse-Vā‘ai 2011; Milner 2012; Ma'ilo 2016). There exist only a few studies that examine the effects of English on the gagana. These studies are organised into the following categories: dictionaries (Pratt 1862; Mosel \& Hovdhaugen 1992; Allardice 2000; Ma'ia'i 2010; Milner 2012); word lists (Cain 1986) and commentaries (Lāmeta 2005; Tamasese 2005; Nunes 2006; Kruse-Vā‘ai 2011; Ma'ilo 2016).

\subsection{1) Dictionaries}


Dictionaries list, rather than describe, the effects of English on the gagana. Although Pratt (1862) has a comprehensive list of introduced words to do with technology and building, he merely references a word's foreign origins by using the word introduced in parenthesis (see $\mathrm{p}$. 79 of Pratt for a description of 'atotau - meaning cartridge). Pratt's limited list of words with English origin in his dictionary is relevant to the time of publication which was only thirty two years after mission arrivals.

Unlike Pratt's dictionary, Milner's (2012) dictionary glosses all English words with the abbreivation E. Some examples include kämuta (carpenter), kanala (canal) and kalama (grammar). In fact, Milner's dictionary recognises all foreign words with abbreviations such as $H$ (Hebrew), $F$ (French) and $G$ (Greek), $S p$ (Spanish), $T g$ (Tongan), $T$ (Tahitian), $R C$ (Roman Catholic), Bb (Bible), Meth (Methodist) and LMS (London Missionary Society). One of the limitations of his dictionary, which Milner (2012, p. xiii) acknowledges in his introduction, however, is the exclusion of people names.

What Milner lacks is neutralised in Allardice's (2000) dictionary in which a comprehensive list of people names, months of the year, medical terms, measurements and material culture are provided. Most dictionaries have an English-Samoan Section where phonetic pronunciations of English words are provided. The comprehensive list of words with English origins, however, lacks any descriptions.

\subsection{2) Grammar manuscripts}

The majority of grammar manuscripts about the gagana used words with English origins in their discussion of Samoan grammar (Downs 1949; Mosel \& Hovdhaugen 1992). Only one manuscript discussed the effects of foreign words, particularly English, on the gagana (Sunia 2014).

Down's (1949) manuscript about Samoan grammar uses a number of words with English origins without any reference to their influences on the gagana. Mosel and Hovdhaugen's (1992) reference grammar is similar. In his manuscript, Sunia (2014, p. 93) is appalled at the extent of fa'apulepule (code switching and fusion) in the gagana. He identifies a number of code switching scenarios in both spoken and written Samoan: (1) nunumi fa 'atasi gagana e lua (using Samoan and English words in sentences); (2) fa 'apalagi le 'upu e tasi (using one English word in a Samoan sentence); (3) fa 'asämoa le 'upu e tasi (using one Samoan word in an English 
sentence); and (4) fa 'ataimi tuana 'i le 'upu Sämoa (using the English suffix -ed with Samoan verbs). For Sunia (2014, p. 96), the government sector is responsible for the rise in code switching. In his concluding comments, Sunia (2014, p. 138) advises that the gagana is losing its true meaning and essence and can only be countered through the prioritising of the gagana in church, government, schools and homes.

\subsection{3) Word lists}

The only word list located that dealt with the effects of English (and foreign words) on the gagana was Horst's lexicon of foreign loan-words in the Samoan language. Horst's (1986, p. xi) work was aimed at providing a list of foreign words which he felt was excluded from Samoan dictionaries. At the time of its publication, Horst (1986, p. xii) maintains that the influence of English became more prominent during NZA and the lead up to and postindependence. English, he continues, has become more prominent as the gagana adapts foreign words according to the phonetical possibilities and requirements of the Samoan language (Horst 1986, p. xiv). Horst's work, however, lacks context descriptions, particularly of the influence of government on the gagana (Murray \& Wesselhoefft 1991). In Horst's defence, though, he does make it clear that his work will need to be updated and supplemented (Horst 1986, p. xv).

\subsection{4) Commentaries}

Commentaries about the influence of English on the gagana are more descriptive and make limited references to the lexicon and grammar. The most detailed discussion of the effects of English on the gagana is Kruse-Vā'ai's (2011) historicisation where she uses the appropriation of English to evaluate societal changes in Western Sāmoa. Kruse-Vā'aai (2011) delves into the correlations between society and language and how these social aspects reflect obsolete, crosscultural and new ideologies.

Macpherson's (2010) article about Samoan language change is also historicisation of the foreign influence in Sāmoa where he begins by discussing the role traders, whalers, explorers, missionaries and administrations played in language change. He completes his historicisation by reflecting on the ways Samoan diaspora have contributed to language shifts in the gagana. 
In his pioneering manuscript about the influences of the missions and missionaries on the gagana, Ma'ilo (2016) historicises the influence of English, and other foreign languages, by focussing on the translation of the Bible. In his discussion, Ma'ilo is critical of the language decisions made by the missionaries which were detrimental to the gagana, with indigenous words, such as pōula (night festivities) and tini (wedding chants), wiped out. Ma'ilo goes further and calls for a revision and decolonisation of the Biblical texts to restore some of the innocent and pure essence of the gagana. But while Ma'ilo calls for a revision of the Biblical texts, Nune's (2006, p. 1) study about the indigenization of foreign words argues that while the influence of English is extensive, Samoans have employed a creative integration of foreign words through the process of indigenization. Rather than reflecting a loss of the gagana, she argues, indigenization has continued to reflect a core of Samoan-ness (also see Mosel \& Hovdhaugen 1992; Macpherson 2010 who agree with changes to the gagana as positive expansions).

Tamasese (2005, p. 66) alludes poetically to the innocence of the gagana in his discussion of cultural practices, such as the $s \bar{a} ' \bar{e}$ (cultural dance), which is no longer practiced as a result of religious conversion. He also maintains, however, that while cultures continue to change, the gagana will reflect these changes. But while these authors outline the positive effects of English on the gagana, Lāmeta's (2005) work, which examines the practical impact of English on the gagana through her discussion of language choice, status, and integration, finds that the co-existence of English and gagana has lead to the elevation of English and has created negative attitudes among some Samoans towards the gagana.

While these studies are valuable, they are largely based on observation. As a result, there is a need for research that combines lexical origin with descriptive analysis through a more systematic and empirical examination of the gagana. There is also a need for a more contemporary analysis on the effects of English on the gagana. Through this research, this thesis addresses the research gaps mentioned above.

\subsection{8) CONCLUSION}

This literature review has demonstrated that Samoans have been under protracted social and ideological contact with foreigners since at least the beginning of the $19^{\text {th }}$ century. For the most part, these social contact events transpired as a result of Western desires for global dominance 
through economic gain, religious conversion and political expansion. Two of the most influential areas of social contact on the gagana has been the church and government.

The presence and operation of the church and government in Sāmoa was successful transformation of Samoan society into a Christian State in quite a short period of time. Both the missionary Church and Westminster State are based on foreign systems of governance that have been adapted to meet Samoa's contemporary cultural and political needs. These introduced institutions have concomitantly been accompanied by associated vocabularies. The missions and consuls are the two most influential institutions that have initiated changes to the Samoan aganu'u and gagana.

This review has also shown that although there exists literature about changes to the gagana, it is not comprehensive and there is a need to conduct more research about the gagana. In fact, there is currently no study that examines the correlation between gagana change and significant societal changes. These two aspects are treated separately in the current literature.

As a result, this research aims to contribute to the existing literature by examining changes to the gagana and how these have been influenced by major societal changes. To do this, a word list consisting of foreign words is created from a corpus of newspaper files. For a more concise examination of changes to the gagana, the discourses of lāuga fa' alelotu (sermons) and lāuga fa 'amatai (chiefly speeches) have been selected as representations of the religious and chiefly contexts of Samoan society. Also, both discourses reflect the introduction and influence of Christianity and government to Sāmoa.

Changes to communication mediums, especially the introduction of print and radio, quickly weakened oral traditions. The weakening of oral traditions was crippling and evident in the dissolving of the orator master-apprentice relationship, which was the amphitheatre of knowledge transfer. Not long after, the perceived superiority of the written word was apparent. Many sermons, for instance, had already been preached throughout Sāmoa. The publication and distribution of Church and consul print texts intensified the effects of the written word on the local oral teaching and learning traditions.

To understand more about gagana change, a diachronic approach is applied by looking at the gagana during various periods of significant societal change. A more comprehensive discussion about this research begins in the next chapter (research methodology). The research questions that have resulted from this review and help guide this research are: 
1. What can a diachronic analysis of the lexicons of lāuga fa 'amatai (discourses of central government) and lāuga fa'alelotu (religious and Church-oriented discourses) tell us about language change in gagana Sāmoa since the arrival of the missionaries in 1830 ?

2. What has been the nature of language contact between läuga fa 'amatai and läuga fa'alelotu?

3. To what extent can changes in the gagana Sāmoa be attributed to social change? 


\title{
CHAPTER THREE
}

\section{METOTIA ILOILO ‘O LE SU`ESU`EGA}

\author{
Research Methodology
}

\section{1) INTRODUCTION}

"...to do research is always to question the way we experience the world, to want to know the world in which we live as human beings. And since to know the world is profoundly to be in the world in a certain way, the act of researching-questioning-theorising is the intentional act of attaching ourselves to the world, to become more fully part of it, or better, to become the world."

(Van Manen 1990, p. 5 \& 6)

Research is not novel to Pacific peoples. For many decades, the Pacific has been a site of much anthropological and sociological research (Tuhiwai-Smith 2008). Yet reflecting on Manen's position about the principles of research, research about Pacific peoples has usually been a tickbox exercise that has led to the misinterpretation of the indigenous worldview (see Mead 1928). This is because aspects of culture and identity, research methods and methodologies influence peoples' understandings of the world (Nabobo-Baba 2006, p. 37). In the last decade, research about the Pacific has shifted from Pacific peoples being the subjects of investigation to becoming researchers initiating research.

This chapter outlines the methods and methodological underpinnings of this research. Two methods are used in this research: (1) corpus study and (2) fa 'afaletui (interviews). Together, the corpus and $f a$ 'afaletui methods provide both a quantitative and qualitative perspective to the research. As a thesis located in the academic contours of Pacific Studies, I begin by examining methods and methodologies from an interdisciplinary sense. I examine ways of doing in Pacific and Samoan cultures from a Samoan-Pacific sociological sensibility. I locate Pacific epistemologies in academic research, and discuss the evolution of Pacific methods and methodologies in research. Finally, I lay a claim for the use of the fa 'afaletui (Samoan-Pacific) 
and Corpus frameworks as appropriate interdisciplinary methods for this research. An outline of sampling, data collection, analysis and research limitations concludes the chapter.

\subsection{1) Key terms and definitions}

There are various terms central to this research and chapter that need to be clarified. The first term is Pacific. My use of the term Pacific refers only to Polynesia, Melanesia and Micronesia and not to the pan-Pacific which includes Asia-Pacific and Australia.

In thinking about indigeneity, I adopt Chilisa's (2012, p. 13) definition where she defines indigenous as a cultural group's ways of understanding reality, ways of knowing, and the value systems that inform research processes. However, it is important to acknowledge here that what is considered indigenous is constantly shifting and changing.

In research, ways of knowing are considered alongside the terms method and methodology. Method and methodology are used in two ways. Firstly, method and methodology are used sociologically to refer to ways of doing. For instance, the methods and methodologies of building a Samoan fale (house) point to context-specific ways of doing housebuilding in Samoan society, which will most likely be different in other Pacific cultures. Secondly, the terms method and methodology are used to reference research frameworks used in academia to probe and research a particular topic.

Finally, the term epistemology refers to ways of knowing. Epistemology is also used interchangeably to mean knowledge.

\section{2) HUMAN ETHICS APPROVAL}

Ethics approval (No. 252237). for this research was granted by the Human Ethics Committee of Victoria University of Wellington to undergo research with insider informants selected for this study (see Appendix One).

\section{3) PACIFIC RESEARCH METHODOLOGIES}

This section discusses Pacific research methodologies and introduces the fa 'afaletui method, to be used in this research. Though distinct methodologies, the corpus and fa 'afaletui are 
conceptually complementary. Whilst the corpus deals with text-language, the fa 'afaletui attends to social relationships. I explain first how the fa 'afaletui fits within the umbrella of Pacific research methodologies and then describe it as a method.

The misrepresentation of Pacific indigenous knowledge and epistemologies in research created a movement to decolonise Pacific research. Led by Pacific academics such as Vaioleti (2006), Manu'atū (2000), Nabobo-Baba (2006) and Thaman (1988), the movement was an approach to liberate the voices and views of indigenous communities in research (Vaioleti 2006; Chilisa 2012). As a result, an improvement in the representation of Pacific voices and views in research was believed to produce more meaningful and accurate research (Anae 2001; Vaioleti 2006; Kalavite 2014).

Pacific methodologies have become increasingly popular in Pacific focussed research, especially in the Humanities and Social Sciences. Some examples of Pacific methodologies include Kaupapa Māori (Tuhiwai-Smith 1999), Mālie-Māfana (Manu'atu 2000), Tivaevae (Maua-Hodges 2000), Kakala (Thaman 1993), Talanoa (Vaioleti 2003), Fa'afaletui (Tamasese, Bush et al. 2000), Vanua (Nabobo-Baba 2006), Tauhi-Vā (Māhina 2004) and the 'Ula (Sāuni 2011).

Though the introduction of a Pacific methodology has been credited to and framed by the ethnicity of the developer, the application of the methods are considered relevant crossculturally within the Pacific, in particular the New Zealand-Pacific, space. The Talanoa methodology, as a specific research methodology, brought to academic existence by Tongan academic Timote Vaioleti, for example, may seem only relevant in Tongan specific research, however, the Talanoa concept exists across many Pacific cultures and languages (Clery 2014, p. 108). In Sāmoa, for example, talanoa consists of the words tala (story) and noa (void or anything). Together it means to talk or converse. These Samoan understandings are similar if not identical to Vaioleti's explanations of the concept in Tongan philosophy. The multitude of Pacific methodologies has created a network of philosophical sharing amongst Pacific and nonPacific academics when conducting and consulting Pacific related research.

But with the cultural-specificity and wide reaching scope of Pacific methodologies, there is cause for caution. The Talanoa, for example, has been viewed as having loose and unclear philosophical configurations (Tunufa'i 2016). In other words, these methodologies come across as being too similar to mainstream methodologies, such as interviews. Pacific methodologies need to be theorised and detached from mainstream methodologies to ensure 
more rigid and methodological contours (Suaali'i-Sāuni and Fulu-'Aiolupotea 2014, p. 336). To detach from mainstream methods requires the validation of Pacific methodologies as being culturally embedded. It claims that this cultural embeddedness is both distinct to and shared across many nations in the Pacific. But because Pacific methodologies are relatively new, conceptualising the contours and rigidity of Pacific methodologies is an ongoing exercise amongst Pacific and non-Pacific scholars with interests in Pacific-related research. Despite this, the regularity of publications, conferences and online teleconferences, such as the Building Research Capacity in the Social Sciences (BRCSS) postgraduate Talanoa sessions, which links academics and students with interests in Pacific research from New Zealand, Sāmoa, Fiji and Australia, there is an up-to-date dialogue about the state and future of Pacific methodologies. With this said, the development of Pacific methodologies has reinforced the need for Pacific methodologies to be the foundation for Pacific-centered research.

As a result, and alongside the Corpus method, this research adopts the fa 'afaletui research method as the Pacific-centred methodological understructure.

\subsection{1) Fa'afaletui}

Fa' afaletui is comprised of three words: (1) fa 'a, (2) fale and, (3) tui. Fa' $a$ is a causative prefix. Fale is the Samoan term for house, whilst tui is the Samoan word weave. In the fa 'afaletui method, fale refers to the various houses of knowledge, such as the house of matai (chiefs/orators) whilst tui reflects the interweaving of knowledge (Tamasese, Peteru et al. 2005). As a methodology, fa 'afaletui is the critical process of tui (weaving) together of the layered articulations of knowledge from within various fale (Tamasese, Peteru et al. 2005, p. $302)$.

As a research model, the fa'afaletui was developed and introduced by Tamasese, Peteru, Waldegrave and Bush (2005). In their research about Samoan health perspectives, which was focus group led, the researchers used the fa'afaletui method to ensure the correct acknowledgement, practice and maintenance of Samoan cultural protocols during their interactions with research insider informants, who were mainly elders. The separation of gender, for example, was implemented to allow sensitive information to be openly discussed (Tamasese, Peteru et al. 2005, p. 302). The fa 'afaletui also instilled sentiments of connection and membership (Tuhiwai-Smith 1999; Nabobo-Baba 2006) amongst insider informants through the use of the vernacular and the dissemination of information governed by Samoan 
cultural values (Tamasese et. al. 2004, p. 306). With the conceptual compositions of the fa 'afaletui in mind, the fa 'afaletui is used in this research based on its Samoan ethno-cultural grounds that positions Samoan values and epistemological ideologies at the centre of its research design (Suaali'i-Sāuni and Fulu-'Aiolupotea 2014, p. 334). Because the fa 'afaletui is a Samoan concept, it allows the researcher and insider informant to acknowledge and address cultural protocols during the interview session. The next section discusses participant sampling.

\section{4) PARTICIPANT SAMPLING}

\subsection{1) Oral sources/semi-formal interviews:}

This research adopted a face-to-face fa' afaletui format. There are several reasons for this. Firstly, I wanted to begin my knowledge search about changes to the gagana by including the perceptions of insider informants with knowledge and experience of the gagana, particularly in the contexts of church and government. Secondly, the idea of fa 'afaletui not only enables social connections, but it demonstrates an appreciation and admiration of the perceptions of insider informants. Face-to-face dialogue, as opposed to focus groups used by Tamasese et. al. 2004, was preferred for the way in which it privileges and embodies in practice the Samoan value of fa 'aaloalo (i.e. cultural respects shown by privileging face to face interactions). Face to face interviews are also known to offer more opportunities for in-depth discussions. Time and participant numbers were other factors of relevance to consider in choosing this method.

The fa' afaletui format was set up as a semi-structured discussion with no pre-determined questions or fixed question structure. Instead, the researcher intiated discussions by prompting questions about their interests in the gagana. This in-turn led to in-depth discussions about the gagana in Samoan society, religion and the diaspora.

All semi-structured fa 'afaletui sessions were conducted at either the participant's home, office or at a local cafe. Potential insider informants were contacted through email by the researcher, but not all those contacted responded. Those who did, however, were informed of the research and agreed to participate. Dates, times and location were then finalised. In all, a total of eight fa 'afaletui interviews were conducted. Insider informants either resided in Sāmoa, Wellington or Auckland. 
All fa'afaletui began with a fa'atūlima. The fa'atülima is a verbal recognition of the arrival/presence of a guest/visitor. The fa'atūlima addresses each party's fa'alupega (salutation), a very important aspect in face to face relational encounters. The successful commencement of the fa'afaletui hinged on the correct recognition of fa'alupega. The fa 'atülima, and the reciting of fa' 'alupega, was maintained throughout the fa' afaletui sessions. This is a traditional Samoan convention and one carried out mainly by Samoans fluent in the Samoan language.

Trust was developed at the start of each fa' afaletui with the fa 'atülima. This was strengthened through shared connections to village, district, research, publications, and family values. These connections created a sense of trust between the researcher and the participant.

On average, each fa 'afaletui proceeded for an hour and fifteen minutes. As the researcher, my main objective was to facilitate. Addressing the privileging of objectivity is a key area in the conceptualisation and implementation of Pacific methodologies (Smith 2012; Vaioleti 2006), such as the fa'afaletui. This is because in the conceptualisation of Pacific research methodologies, the positionality of the insider/outsider roles are not considered separate entities. As Pacific peoples conducting Pacific research, for instance, we are both insiders and outsiders in a sense that as researchers we have a connection to the researched community. As a result, insider research is required to be, as described by Smith (2012, p. 139), as ethical and respectful, as reflexive and critical, as outsider research. One of the benefits of being both an insider and outsider in this project has been the ability to negotiate the research process in ways that were beneficial for both the the insider informants and the researcher. One of the most controversial misrepresentations of the Samoan people, for instance, was Margaret Mead's work where she claimed that nurture prevailed over nature in Samoan adolescence. As an outsider, and though her assessment was an informed one, it was informed by her own Western observations and without insider perspectives. As a result, I ensured that the views of insider informants were valued and respected and not marginalised or hidden throughout this project. Moreover, all fa' afaletui were conducted using cultural protocol, the gagana and concluded with words of thanks and the presentation of a gift.

\subsubsection{Insider informants}

Each fa' afaletui insider informant had to fit more than one of the following criteria. Each insider informant had to be: 
1. a Samoan matai (ali 'i or tūlāfale), OR

2. a Samoan faife 'au, a'oa'o (layman) or ti 'ākono (deacon)

3. an expert in Samoan language and culture, and/or

4. contributed to literary and academic discussions around the Samoan language, traditional oratory and sermonry.

Below is an explanation of the above criteria:

Criteria 1: Under the matai criteria, both ali 'i and tūläfale were sought. There were several reasons for this. Firstly, both ali' $i$ and tüläfale can perform lāuga, despite the performance of lāuga being rare amongst the former class. Secondly, many Samoans (male and female) have numerous matai titles. Samoa's Prime Minister, for instance, is the holder of seven matai titles, four of which are tüläfale titles, the rest are ali ' $i$ titles.

Criteria 2: In most Samoan denominations, particularly the mainstream denominations of Congregational, Methodist and Catholic, only ordained or ecclesial members can perform a fa'alelotu lāuga. In the Congregational denomination, for example, these members are faife 'au (clergy) and $a^{\prime}$ 'oa'o (lay preacher). Ti 'ákono (deacons) cannot perform a lāuga fa'alelotu, but can perform a lāuga fa'amatai. To put into some perspective, the $t i$ ' $a$ kono perform similar roles to tūláfale, but they do not necessarily have to have an orator title to perform this role. They are considered like tūläfale because they are the spokespersons for faife ' $a u$ and a congregation. Additionally, faife 'au and a' oa' $o$ cannot perform a läuga fa'amatai because of their clergy status, which is under decree by the Church's standing resolutions. Breaking these religious codes of conduct are consequential. In most cases, it will likely result in one's removal from office.

Clergy insider informants were not confined to only the Samoan Congregational denomination. It was widened to include Methodist and Catholic clergy. However, of the three faife ' $a u$ who responded and participated, two are Congregationalist (Pita and Ioelu) and one is Methodist (Ioane). Catholic clergy were either unavailable or did not reply. However, one insider informant (Tina) who grew up in the Catholic church and had intricate knowledge of Samoan Catholicism, but is now a Congregationalist, participated.

Criteria 3: Knowledge of the Samoan language, oratory or sermonry were vital criteria because of the centrality of these areas in the examination of Samoan language change 
in this study in the contexts of Samoan society, government and church. Generally, insider informants were knowledgeable and accomplished experts in all contexts.

Criteria 4: Alongside cultural and everyday knowledge and experience of language, oratory and sermonry, the rigours of academic exposure is also an important exponent. This is important to this study because it demonstrated in-depth knowledge of concepts, such as the correlation between language and society, to the overall depth of information. Many insider informants had publications on either the Samoan language, oratory or semonry. Others were experts on translation, Samoan religion and history.

While gender was not a criteria, an effort was made to ensure both male and female views were included. This provided both gender transparency as a balance to the hyper-masculine nature of lāuga fa' 'amatai and lāuga fa' 'alelotu in Samoan society and the church.

In regards to the insider informants perceptions, they were asked to provide their opinions on Samoan language change, particularly the influence of the missions and government. An interesting point about the insider informants was the different hats they wore. They, for instance, were matai, academics, authors, cultural experts, and/or ordained clergy of the Church. As a result, insider informants ranged from two faife 'au of the Congregational denomination, one faife ' $a u$ from the Methodist denomination, three language experts, and two cultural experts. Table Three below demonstrates the various roles held by each insider informant. 
Table 3:

$\underline{\text { Social and Religious Status of Insider Informants }}$

\begin{tabular}{|c|c|c|c|c|c|c|c|c|c|c|}
\hline \multirow{2}{*}{$\begin{array}{c}\text { Insider } \\
\text { Informan } \\
\mathbf{t}\end{array}$} & \multirow{2}{*}{ Ge } & \multirow{2}{*}{ Cler } & \multicolumn{2}{|c|}{ Matai } & \multirow{2}{*}{ Dea } & \multirow{2}{*}{$\begin{array}{c}\text { Gov/Of } \\
\mathbf{f}\end{array}$} & \multirow{2}{*}{ Auth } & \multirow{2}{*}{ Acad } & \multirow{2}{*}{ Educ } & \multirow{2}{*}{$\begin{array}{c}\text { Lang/ } \\
\text { Cul } \\
\text { expert }\end{array}$} \\
\hline & & & chief & orator & & & & & & \\
\hline Ioane & M & $\checkmark$ & & & & & $\checkmark$ & $\checkmark$ & $\checkmark$ & $\checkmark$ \\
\hline Pita & M & $\checkmark$ & $\checkmark$ & & & & $\checkmark$ & $\checkmark$ & $\checkmark$ & $\checkmark$ \\
\hline Tina & $\mathrm{F}$ & & & & $\checkmark$ & & & & $\checkmark$ & $\checkmark$ \\
\hline Ioelu & $\mathrm{M}$ & $\checkmark$ & & & & & & & $\checkmark$ & $\checkmark$ \\
\hline Mose & $\mathrm{M}$ & & & $\checkmark$ & $\checkmark$ & & & & & $\checkmark$ \\
\hline Saga & $\mathrm{F}$ & & $\checkmark$ & & & & & & $\checkmark$ & $\checkmark$ \\
\hline 'Ina & $\mathrm{F}$ & & & & & & $\checkmark$ & $\checkmark$ & $\checkmark$ & $\checkmark$ \\
\hline Sina & $\mathrm{F}$ & & & & & $\checkmark$ & $\checkmark$ & $\checkmark$ & $\checkmark$ & $\checkmark$ \\
\hline
\end{tabular}

KEY: $G e=$ gender; $C l e r=$ clergy; Dea $=$ deacon; Gov/Off = government official; Auth $=$ author;

$E d u c=$ educator Lang/Cul expert $=$ language and cultural expert

The limitations of $f a$ 'afaletui are discussed in detail in Chapter Seven (Conclusion). The reason for discussing the limitations of fa' afaletui here is to highlight the methodological contributions made through the combined use of the fa 'afaletui and corpus methodologies and methods. Speaking of the corpus methodology, the next section discusses the implementation of the corpus methodology in this research. The significance of the implementation of the fa 'afaletui and corpus methodologies and methods is that they provide an alternative to the oral perspective focus of Pacific Studies research and the empirical contours of corpus studies if used separately.

\section{5) CORPUS}

\subsection{1) Description}

A corpus is a body of naturally occurring language (Dazdarevic, Zoranic et al. 2015). This body of language is a representation of a particular language or a variety of a language (Hunston 2006, p. 234; McEnery, Xiao et al. 2006, p. 5). Designed to investigate language use (McEnery 
and Hardie 2011, p. 1), corpuses are comprised of authentic texts (including transcripts of spoken data) that are sampled and categorised into machine-readable configurations (McEnery, Xiao et al. 2006, p. 5) for contextual interpretation (Biber 1998, p. 3). One of the benefits of using a corpus is it "...allows...[an examination] of certain language features in context" (Dazdarevic, Zoranic et al. 2015, p. 4), There are two sources of language included in corpora: these are (1) spoken and, (2) written (Biber et. al 1998). Spoken language consists of a collection of transcribed audio files. Written corpora comprise a collection of written texts. However, differentiating between either spoken or written is too simplistic. Basically, modern corpora can represent either written, spoken, or a combination of the two. When combined, as an example, some corpora may comprise a $70 \%$ written and $30 \%$ spoken ratio. In addition, there are corpora that collect written language, such as the International Corpora of English (ICE), and corpora that collect spoken language, such as the Arabic Speech Corpus (ASC). Often, the spoken corpora is presented as written, but is a product of spoken.

For this research, the corpus is comprised of written and published texts. This was based on the impossibility of locating actual recordings of spoken Samoan that (1) documented the discourses of interest (speeches/sermons) and (2), aligned with the indicator year periods. Further descriptions of the language discourses and indicator years are provided below.

\section{6) CORPUS SAMPLING}

\subsection{1) Historical Framework (Indicator Years)}

This research is a text-based, diachronic examination of changes to the gagana. The diachronic underpinnings of the research require significant contact periods. I viewed significant post contact Samoan history as being divided into the following four periods:

Christianity Period:

(circa 1830-1899)

Colonial Period:

(circa 1900-1961)
This period marks the arrival of the missionaries and acceptance of Christianity in Sāmoa. Written Samoan was established by the missionaries during this period. It offers a logical starting place for tracing gagana change using written Samoan sources.

The years 1900 and 1914 were significant periods in Samoa's history because of the arrival of the German and New Zealand administrations, respectively. The period 
of German and New Zealand colonial rule in Sāmoa was significant for their introduction of national processes for law and order, such as the establishment of the 1903 Land and Titles Commission and village komiti (committees).

Independent Nation-State

Sāmoa achieved Independence from New Zealand administration in 1962. This period saw a turning point in Samoan contact with the outside world. From this point Sāmoa, as an independent country and member of the United Nations, was now in contact with the outside world in quite different ways from the earlier periods. Becoming an independent nation state in the 1960s also meant that Sāmoa had to rethink its national governance strategies, including having to address developing national competencies in those languages relevant to building a productive workforce. These governmental changes affected the development of the gagana, especially in schools. The educational policy, for instance, was to educate students in English to enable them to fill higher positions in all spheres of Samoan society (New Zealand Department of Island Territories 1951, p. 99).

Diaspora Period:

This last period marks the development of the Samoan (circa 1972-present) language through interactions between the home country and diasporic Samoan communities. With increasing numbers of Samoans being born in New Zealand, and increased travel between the two countries, including settlement and co- citizenship in both countries, there are significant interactions between gagana Sāmoa in New Zealand and Sāmoa.

To make sense of these four key periods of Samoa's contact history in examining diachronic and synchronic text-based changes to the gagana Sāmoa, I adopt Macalister's (2007) Indicator 
Year framework as the historical and conceptual foundation (see section 3.8.8 for a detailed discussion of Maclister's work). The Indicator Year tool is applied to frame the collection and analysis of the corpus. It should be pointed out that the Indicator Years in Figure 1 are not aligned with the four key periods of Samoa's contact history. The were two main reasons for this: (1) avalability of sources and, (2) historical contact significance. These criteria are discussed and illustrated in Figure 1 below:

Figure 1:

Diachronic (Indicator Years) and Contact Period

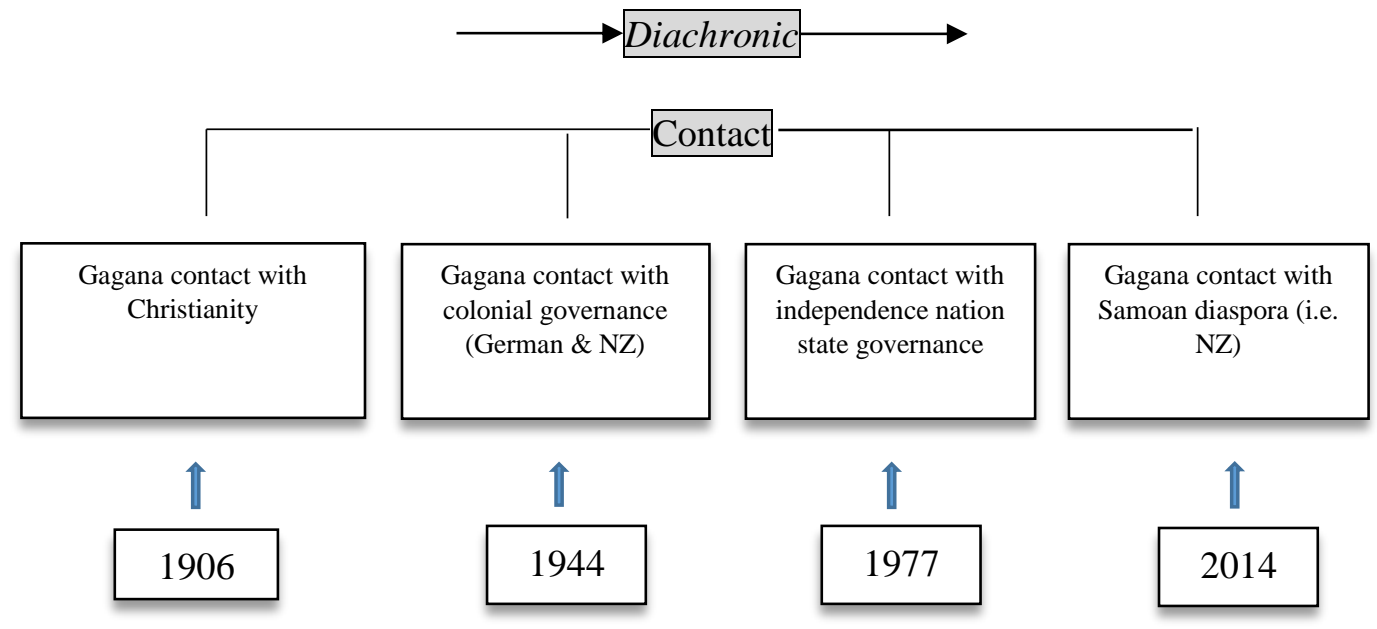

The selection of the indicator years was challenging. Initially, my proposed indicator years were 1830, 1900, 1970 and 2014. Each of these indicator years were selected based on a direct alignment to significant social events in Sāmoa and provided an even time period of seventy years. The years 1830 and 1900, for example, were the exact years Christianity arrived in Sāmoa and the Germans (consul) annexed Sāmoa. However, it was soon realised that the sources that were available did not align with the proposed dates. Therefore, the revised indicator years, particularly 1906, 1944 and 1977, were selected based on source availability for both newspapers while remaining closely aligned with events of significant social change in Sāmoa. The year gaps between 1906-1944-1977 and 2014 are 38, 33, and 37 years, respectively. As a result, the revised indicator years present an approximation of generational measure.

3.7) LĀUGA FA'AMATAI AND LĀUGA FA'ALELOTU: Methodological definitions 
Two central concepts in this thesis are lāuga fa 'amatai and läuga fa 'alelotu. The descriptions of both lāuga discourses have been provided in sections 2.9 and 2.10 of Chapter Two, respectively. To revisit, lāuga fa'amatai are formal speeches performed by matai (chiefs/orators) during Samoan rituals. In contrast, lāuga fa'alelotu are church sermons performed by faife 'au (clergy).

In this thesis, the fa 'amatai discourse is used to refer to the discourse of central government. The term fa'amatai refers to the traditional matai (chiefly) system, Samoa's pre-European political and governance system. As a result, the use of the phrase lāuga fa 'amatai refers to the vocabularies associated with the fa' amatai system. There are a number of distinct differences between gagana fa 'amatai (traditional chiefly discourses) and its concomitant vocabularies, and the gagana fa 'a 'upufai (central government discourses) and its concomitant vocabularies. To illustrate, a minisitā 'o le kapeneta (cabinet minister) in government can be likened to the traditional office and status of fale upolu 'o tôfiga ${ }^{12}$, who is the paramount orator of a village (and/or district orator groups). Though there are obvious overlaps, their key origins and key drivers are not the same. Though the term fa'a'upufai, which means central government discourse was considered, the word fa'amatai, and its ideologies, was preferred for the following reasons. Firstly, all but two individuals who are elected into government have to be matai. As a result, all elected members of parliament are matai. As matai, they are representatives of their village and district in government affairs. Secondly, as matai, they are both in the old and new system of governance and because of the indicator years adopted, a term which represented the continuity of both the old and new system was adopted. Because of these reasons, lāuga fa 'amatai as used in this thesis are text-based formal speeches that have been identified using criteria in sections 3.8.3 and 3.8.4 that were published in the government newspaper Sāvali.

In contrast, the $\mathrm{fa}$ 'alelotu discourse (religious and Church-oriented) refers to the discourse used in the Congregational Christian Church of Sāmoa (CCCS). Unlike lāuga fa'amatai, sermons were documented almost immediately after the arrival of the missionaries. The earliest sermon documented that I have found was published in the 1836 Sulu Sāmoa. As a result, lāuga fa' 'alelotu used in this thesis are text-based sermons that were identified using criteria in

\footnotetext{
${ }^{12}$ Fale 'upolu 'o tôfiga are high ranking orators and orator groups in Samoa's traditional hierarchy of Tūmua ma Pule. Tūmua is the national orator group of the island of 'Upolu while Pule is the national orator group of Savai' $i$. 'Upolu and Savai ' $i$ consist of the two main islands of Independent Sāmoa.
} 
sections 3.8.3 and 3.8.4 that were published in the CCCS newspaper Sulu Sāmoa. The next section discusses the text sources and sampling frame used.

\section{8) TEXT SOURCES}

The corpus consists of texts from two different newspapers: (1) Sulu Sāmoa (Sulu) and, (2) Sāvali. The Sulu is a Church newsletter. The Sāvali is Samoa's government newspaper. The main purposes of the corpus are:

- to provide a representative examination of gagana change at synchronic and diachronic time periods.

- to compile a body of text-based language from which claims about language and the social environment can be made.

\subsection{1) Sulu}

Today, the Sulu is published twice a month and is accessible online. The increase in print and online production was a concerted effort by the Sulu Office for improved public accessibility and storage. Accessibility and storage were issues encountered during the sourcing of texts. In a conversation with current Mālua Theological College lecturer Latu Lātai (2016, personal communication), he noted that many issues of the Sulu are either lost or in the possession of faife 'au (clergy). This was verified during a visit to the Sulu office at the John Williams Building in Sāmoa which only had recent publications (2000-2014) of the Sulu.

\subsection{2) Sāvali}

First published in 1905, the Sāvali was set up and first published by the German administration only five years after their annexation of Sāmoa. Publication of the Sāvali was continued by the New Zealand administration after the forced departure of the Germans. Since Samoa's political independence in 1962, publication of the Sāvali has been continued by the Samoan government.

Like the Sulu, many issues of the Sāvali are unaccounted for. In conversation with the Head Librarian at the Nelson Memorial Library and the Sāvali Office in Apia, I found that many copies of the Sāvali were not stored. Copies that were, were damaged during Samoa's 
numerous cyclones. Today, apart from some physical copies from the 1970's, mostly digital copies remain.

\subsection{3) Sampling frame for corpus texts}

The corpus is comprised of texts in the gagana from the written text-based sources only. The following criteria for source inclusion were:

Table 4:

Text Sampling Frame

\begin{tabular}{|c|c|}
\hline 1. Author: & $\begin{array}{l}\text { Authors are one or more of the following: a matai } \\
\text { (chief/orator); a faife 'au; a representative of a church } \\
\text { organisation, governance or educational group. }\end{array}$ \\
\hline 2. Type of text: & Written lāuga. \\
\hline 3. Lāuga & $\begin{array}{l}\text { Speeches, sermons, government notices, meeting minutes, } \\
\text { funeral notices, church fundraising notices, lands and titles } \\
\text { summon notices and lands and titles verdict notices. }\end{array}$ \\
\hline $\begin{array}{l}\text { 4. Publication } \\
\text { medium: }\end{array}$ & Published online or in hardcopy print form. \\
\hline $\begin{array}{l}\text { 5. Date of } \\
\text { publication: }\end{array}$ & Between 1906 and 2014. \\
\hline 6. Use of gagana: & $\begin{array}{l}\text { Texts are published either entirely in the gagana or bilingually } \\
\text { in Samoan and English. }\end{array}$ \\
\hline
\end{tabular}

The sources were obtained from public, tertiary and theological libraries, Church institutions (Sulu Office), National Archives, the Sāmoa Land and Titles Court, book shops and government departments in Sāmoa and New Zealand. Table 5 lists the institutions where the Sulu and Sāvali used in this research were primarily located: 
Table 5:

$\underline{\text { Sulu and Sāvali sampling }}$

\begin{tabular}{|c|c|c|c|}
\hline \multicolumn{2}{|c|}{ Sulu } & \multicolumn{2}{|c|}{ Sāvali } \\
\hline 1906 & $\begin{array}{c}\text { National University } \\
\text { of Sāmoa Campus, } \\
\text { Apia. }\end{array}$ & 1906 & $\begin{array}{c}\text { Sāvali Office, } \\
\text { Government } \\
\text { Building, Apia. }\end{array}$ \\
\hline 1944 & $\begin{array}{l}\text { Mālua Theological } \\
\text { Library, Sāmoa. }\end{array}$ & 1944 & $\begin{array}{l}\text { Land and Titles } \\
\text { Court, Mulinu'u, } \\
\text { Apia. }\end{array}$ \\
\hline 1977 & $\begin{array}{c}\text { Congregational } \\
\text { Christian Church } \\
\text { Sāmoa (CCCS) Book } \\
\text { Shop, Apia }\end{array}$ & 1977 & $\begin{array}{l}\text { Nelson Memorial } \\
\text { Public Library, Apia }\end{array}$ \\
\hline 2014 & Sulu Office, Apia. & 2014 & $\begin{array}{c}\text { Sāvali Office, } \\
\text { Government } \\
\text { Building }\end{array}$ \\
\hline
\end{tabular}

\subsection{4) Identifying lāuga in written form}

The text types in the sampling frame (Table 4) were a significant criterion on which requires further explanation. It is important to confirm that all the examined files were written läuga. To identify and differentiate between the various kinds of lāuga in written form, vocabulary choices in the texts were crucial. Identifying vocabularies was crucial for two reasons:

1. Though there is lexical overlap, Samoan lāuga generally consists of context specific words which are not used interchangeably between contexts.

2. The use of context specific words enabled the researcher to categorise the differences between lāuga forms.

As an example, the word tülouna, which refers to the pardoning of the spirit world in Samoan oratory, is only used in funerals. The word lägia, which is reference to the residence of a deceased person, is another example. Though context-specific words may be used in a sermon, for example, it is used only as a reference to the ideology. The metaphor 'ia fua le niu, a saying 
commonly used to refer to human reproduction, is only used in fa'aipoipoga (weddings). Vocabulary choice was the main lexical aspect used to identify not only lāuga in the written form, but the identification of the various forms of lāuga. A general observation of texts in discussed in Section 3.8.5.

\subsection{5) Some observations on texts}

During this research, some research observations about the texts were made and need mentioning. These are outlined as follows:

- Apart from the Sulu 1906 and 1977, no photocopying of the above resources was permitted. As a result, copies had to be taken by camera and were stored on a personal laptop.

- Out of all texts, only copies of the Sulu 1977 were purchased from the Congregational Christian Church Sāmoa (CCCS) Book Shop in Apia for \$10. These were the only 1977 Sulu editions found.

- It was not feasible to acquire all issues of Sulu and Sāvali. That is, for instance, for the Sāvali 1906, only January-April and June-August editions were found. The May, September, October, November and December issues, however, were missing.

- Whilst the majority of the issues were incomplete, some issues, for example, Sulu 1906, 2014; Sāvali 1944, 1977 and 2014, were complete. Some annual newspapers, such as the Sulu 1944, are missing only a couple of months in the issue.

- All authors in the published issues were either a faife'au or a matai.

- Despite some usage of English words in text, the majority of the texts were written and published in the gagana Sāmoa. German was used in both the Sulu and Sāvali in 1906.

- Only the 2014 newspapers for both Sulu and Sāvali were in PDF format and available online.

\subsection{6) Corpus Size}

The terms type and token are used from this point forward to mean word and word frequency, respectively. Both terms are common vocabularies in corpus studies. Most modern corpuses, such as Spoken New Zealand English (SNZE) and Written New Zealand English (WNZE), are at least 1 million words in size and consist either of complete texts or of large extracts from 
long texts (Hunston 2006, p. 34). The goal of examining the corpus was to create a word list of words of foreign origin. The total number of foreign types identified in the examined files are 1,975 types and 7,123 tokens.

The corpus is comprised of all acquired Sulu and Sāvali newspapers for the years 1906, 1944, 1977 and 2014. On average, the number of pages for an indicator year per source was 300-400 pages. This was especially prominent in the years 1977 and 2014, but it varied between newspaper. The Sulu in 1906, for example, had 12 complete newspapers. The Sāvali 1906 editions, however, were incomplete. As a result, the Sāvali 1906 had fewer words and total pages.

\subsection{7) Piloting}

The piloting stage was very useful for the final design of the corpus. It was a process of trial and error. The intent was to come up with a workable corpus framework that I could use. But before I outline the framework, I must make known some of the piloting measures taken.

One of the first things I did in the piloting phase was construct a demo corpus using various Sulu issues, one of them being the first ever Sulu publication of 1843 held at the NZNL in Wellington. This was beneficial for a number of reasons. Firstly, I began to construct a narrative and appreciation of language evolution. I started to think about how the gagana may have sounded, for instance, in 1843 and whether the text I was examining matched it. I was also intrigued at the number of words, particularly ones in 1843, that I was unfamiliar with. These include 'Apokalupo, faī' 'oga fa'aola, 'Isalaela (possibly Israel) and fa'alogolo. One of the things that really struck me also was changes in orthography. Words such as lalo nei (on earth), ata li (everlasting), lalo lagi (earth), vāvā nimonimo (sky or galaxy) and fa 'aumataga (conclusion) are spelt lalonei, atalì, lalolagi, vānimonimo and fa 'a 'umaga (or aotelega) today. Secondly, I also began to develop and improve on the practicalities of lexical identification, coding and collocation. These personal discoveries would help me to finalise my corpus framework. As an example, I began to develop an understanding of what information was important and what was not.

Identifying foreign types was a gradual process. I had to learn, for instance, that apart from transliterations, a direct marker of foreign types, foreign meanings were also attached to existing words. Early on, this complicated the identification process. A couple of strategies 
were used to assist, however. Firstly, my background knowledge in the gagana was useful in interpreting foreign types. Secondly, I consulted the etymology interpretations in Samoan dictionaries. In other cases, particularly for words not found in dictionaries, various ethnographic texts were very helpful. For example, Augustin Kramer's dual volume of the Sāmoa Islands first published in 1903 comprises many indigenous and foreign Samoan words. Other texts include the writings of one of Samoa's prominent linguistic and cultural custodians, former Samoan Head of State Tui Atua Tupua Tamasese 'Efi. Many other sources, such as Mosese Ma‘ilo's (2016) recent text Bible-ing my Samoan, were also used. These various texts were helpful in the identification of foreign types. It also exposed me to the various ways words were coined to accommodate foreign meanings.

Deciding on the preferred type codification was important. When I first started, types were entered into the word list based on the root word. For example, the foreign types Aso Sa (Sunday), Aso To 'ana 'i (Saturday) and Aso Penetekoso (Pentecost) were entered under the root word aso (day). However, it became clear that coding foreign types this way was not efficient for two reasons. Firstly, it was time consuming to sift through the type lists to identify foreign types. Secondly, doing it this way allowed more room for error. Foreign types, therefore, were inserted into the word list using the full type collocation. So instead of coding foreign types under the root word, such as the example provided above, foreign types were coded as they appeared. A more comprehensive account of compiling and coding is provided next.

\subsection{8) Compiling and coding}

All the text types for the word list were entered into a database. Types (words) were entered into the corpus based on foreign meaning and form. Initially, I adopted Macalister's (2007) foreign word categorizations of form and meaning, which he used to examine the increasing influence of Māori words in New Zealand English, to identify foreign words for the corpus. However, it became apparent that foreign words in Samoan did not take a foreign form but were only foreign in meaning. This is because all foreign words in the gagana follow the orthographic patterns of the gagana and are therefore Samoanized. The post-Western words such as palemene (parliament) and palemia (prime minister), for instance, are foreign in meaning but not form. In addition, words such as tusi (book) and lotu (Church), both preWestern terms, which have had an added meaning to its indigenous sense, are foreign in 
meaning, also. Macalister's (2007, p. 495) Lexical Outcomes of Language Contact (LOLC) is provided in Figure 2 below:

Figure 2:

Macalister's (2007) Lexical Outcomes of Language Contact ${ }^{13}$

\begin{tabular}{|c|c|c|c|c|c|}
\hline & Loanwords & Loan translations & Semantic loans & Hybrids & Neologisms \\
\hline Meaning & From A & From A & From A & $\begin{array}{l}\text { From A and } \\
\text { or B }\end{array}$ & From A \\
\hline Form & $\begin{array}{l}\text { From A: a new } \\
\text { word added to } \\
\text { the lexicon of } \\
\text { B }\end{array}$ & $\begin{array}{l}\text { From B: a new } \\
\text { word created } \\
\text { from existing } \\
\text { elements in B } \\
\text { based on a } \\
\text { model from A }\end{array}$ & $\begin{array}{l}\text { From B: a new } \\
\text { meaning added } \\
\text { to an existing } \\
\text { word in B }\end{array}$ & $\begin{array}{l}\text { From } \mathrm{A} \text { and } \mathrm{B} \text { : } \\
\text { a new word } \\
\text { created from } \\
\text { existing } \\
\text { elements in } \\
\text { both A and B }\end{array}$ & $\begin{array}{r}\text { From B: a new } \\
\text { word created } \\
\text { from existing } \\
\text { elements in B }\end{array}$ \\
\hline $\begin{array}{l}\text { Potentially } \\
\text { recognisable } \\
\text { to } \\
\text { monolingual } \\
\text { A-speaker }\end{array}$ & Yes & No & No & No & No \\
\hline $\begin{array}{l}\text { New Zealand } \\
\text { English } \\
\text { example }\end{array}$ & $p a$ & meeting house* & flax & $\begin{array}{l}\text { Maori bread } \\
\text { Maoridom } \\
\text { huia bird }\end{array}$ & parson bird \\
\hline
\end{tabular}

${ }^{*}$ From Maori whare runanga. Loan translations are, however, extremely rare in New Zealand English.

For the purposes of this current section, the key differences between Macalister's model and its modifications to reflect foreign words in the gagana were in the areas of hybrids and neologisms. A more comprehensive discussion of these differences is provided in section 6.3 of Chapter Six (Discussion).

It is important to note that the identification of foreign words was aided with the knowledge that words containing the consonants $h, k$, and $r$ were likely to be of foreign origin, as these consonants were introduced by the missionaries to accommodate foreign words. In hindsight, the piloting work was essential in determining the criteria for foreign word identification and inclusion.

After a type was identified as foreign (meaning), each type was entered into the corpus and categorised under one of five lexical outcomes of contact (loanwords, loan translations,

\footnotetext{
${ }^{13}$ Extracted from Macalister, J. (2007). Weka or Woodhen? Nativization through lexical choice in New Zealand English. World Englishes, Vol. 26 (4), p. 492-506.
} 
semantic loans, hybrids and neologisms) (Macalister 2007). Categorising each type was useful in making sense of the types of lexical outcomes existent in the language.

The coding of the corpus was consistent throughout. The corpus was coded, in exact order, under the following headings: (1) Type; (2) Month/Page; (3) Token; (4) Meaning/Translation; (5) Lexical Outcome and (6) Collocation.

Type:

Type refers to word (see section 3.8.6). The word faife 'au, meaning church pastor, for instance, is a type.

Month/Page:

Token:

Meaning/translation:

Lexical outcome:

Collocation:

Coding Template

\begin{tabular}{|c|c|c|c|c|c|}
\hline Type & $\begin{array}{c}\text { Page } \\
\text { Number }\end{array}$ & Tokens & Meaning & $\begin{array}{c}\text { Lexical } \\
\text { Outcome }\end{array}$ & Collocation \\
\hline \multirow{3}{*}{ 'Āgelu } & $40|41| 43 \mid 58$ & $1|1| 0 \mid 0$ & & & 'Ua fetalai se \\
& $59|66| 67 \mid 68$ & $0|0| 0 \mid 0$ & Angel & Loanword & 'āgelu iā te ia \\
& $88|89| 90 \mid 99$ & $0|0| 0 \mid 1$ & & & \\
\hline
\end{tabular}




\begin{tabular}{|c|c|c|c|c|c|}
\hline & $100|115| 116$ & & & Fetalai se ‘āgelu \\
$117|118| 147$ & $0|0| 0$ & & & iā te ia \\
$148 \mid 149$ & $0|0| 0$ & & & \\
& & $0 \mid 0$ & & & \\
\hline
\end{tabular}

\subsection{9) Inter-rater}

Because the corpus was manually compiled by the researcher, an inter-rater was employed to create a second word list based on $10 \%$ of the original files. During meetings with the interrater, information about the Indicator Years framework and the Lexical Outcomes of Language Contact types (Macalister 2007) was discussed.

The objective of the second corpus was to ensure the reliability of the analysis. Both analyses were then compared for similarities and differences. The following steps became the scope of the second corpus:

1. the second word list was compiled from $10 \%$ of the original corpus.

2. $10 \%$ of the second corpus entailed 1 monthly issue per Sulu and Sāvali editions for each indicator year (1906, 1944, 1977, 2014).

3. both corpuses were compared and discussed to measure and determine the realiability of the corpus.

Results of the inter-rater work is as follows:

- Rigid discussions were held with the inter-rater about the etymology of some words. There was some uncertainty around a few types. For example, the word teufugāla 'au (bouquet) was marked as foreign in the inter-rater's corpus but not in the main corpus. After discussing the type, we both agreed that bouquet, particularly the idea of presenting flowers, is a foreign type. Other types discussed include tu' 'ugamau (grave). The idea of concreting graves was foreign, but the practice not. Therefore, tu'ugamau was not included in the corpus, but the type $\operatorname{sim} \bar{a}$ (concrete) was.

- Anapogi (fast) was another type discussed. We talked about whether Samoans' practiced fasting in pre-Christian times. We managed to unpack the word which consists of ana (cave) and pogi (darkness) and identified that both words are indigenous. We were fortunate to be able to support that anapogi, according to 
Tamasese (2005, p.12), is an indigenous concept and was a traditional way of disciplining and calming the body, mind and spirit. The use of sources was a good way to support our discussions.

- Fa'aipoipoga, which means wedding, was also debated. Though academics such as Tamasese (2005) and Ma'ilo (2016) disagree on etymology of the type as being indigenous and foreign, respectively, we came to the conclusion that the word is foreign based on the idea that what is practiced today has been influenced immensely by the missionaries. We also based our decision on the indigenous word for wedding which was nunuāvaga, which has been stamped out by the influence of Christianity.

- The exercise was beneficial for the inclusion and eliminating of types that were either missed or were not foreign. For example, the inte-rater's corpus provided words that were not included in the main corpus. Some of these types include fa 'auluga (entry fee) and fa' afouina (type of service in the Church).

- Overall, the main corpus and inter-rater's analysis share similar results across the four indicator years. Apart from the types mentioned, most of the corpus was near identical. This is indicated when comparing both corpuses for Savali 1977 where only one token was the difference between the two.

\section{9) FA'AFALETUI AND CORPUS ANALYSIS}

Data analysis refers to the methodological interpretive approaches that "...emphasize the iterative nature of knowledge and knowledge making... and their ties to the experiences of both researchers and researched" (Yanow, Schwartz-Shea \& Peregrine 2015, p. 255). There are two sources of data in this research. These are insider informant perceptions and text. The perceptions of insider informants are used to provide foreground to the corpus findings. Text refers to "...an instance of language in use, either spoken or written: a piece of language behaviour which has occurred naturally, without...intervention" (Stubbs 1996, p. 1). In analysing the data obtained, my analysis of the corpus and of the fa 'afaletui narratives involved quantitative, qualitative and Pacific research principles and methods. The analysis of the corpus and fa' afaletui has developed as follows.

\subsection{1) Fa'afaletui}


The inclusion of the perspectives of insider informants was to obtain an active perspective on Samoan language change. The inclusion of these perspectives is important, especially in Pacific research (Nabobo-Baba 2006, p. 24), for here each fa' afaletui session offered an insightful perspective into the existential dynamics and bureaucracies of the Samoan language in the Church and State domains.

Though the anecdotes from the fa'afaletui are supplementary information to the corpus, organising the anecdotes into thematic features remained valuable. The anecdotes are organised into the following themes which emerged through content analyses of the fa'afaletui interviews:

1. Effects of Christianity on the gagana.

2. Effects of government on the gagana.

3. Standardising the gagana.

4. Transnational networks and Samoan identity.

\subsection{2) Corpus analysis:}

The corpus was analysed and interpreted diachronically and synchronically to enable comparative and historical analyses of language change (Deverson 2000, p. 30). A diachronic analysis allows insight into changes to a language over time. A synchronic analysis compares similarities and differences between text sources at the same point in time.

\subsection{3) Lexical outcome analyses:}

During the analysis of the corpus, types were organised into typologies structured around Macalister's (2007) five LOLC. These are (1) loanwords, (2) loan translations, (3) semantic loans, (4) hybrids and (5) neologisms. These LOLC were organised into categories. Seven categories have been identified to accommodate the types of LOLC in the corpus based on a content analyses of foreign word types in the corpus. These are:

- Place names (PLN)

- Proper nouns $\quad(\mathrm{PN})$

- Religious culture (RC)

- Social culture (SC) 
- Material world

- Natural Environment (NE)

- Other

\subsection{4) Comparative analysis:}

Comparative analysis is a common feature in corpus linguistics and also of Pacific research. The two sources of lāuga, the Sulu and Sāvali, are compared to construct a narrative of the influences of the respective discourses (lāuga fa' 'amatai and lāuga fa'alelotu) on the gagana Sāmoa. The text representative of the gagana Sāmoa in 1906, 1944, 1977 and 2014 for the Sulu is compared with the text sources of the Sāvali for the same years for a synchronic analysis.

\subsection{5) Quantitative analysis:}

Frequency and average are central to the numerical aspect of statistical analysis. Frequencies, for example, are provided by the number of times a type occurs. These frequencies are also narrowed further with an analysis of month and issue. Frequencies of a type are also extended to include interpretations aligned with text source (Sulu and Sāvali), indicator year, and issue.

The comparative/historical, typological and statistical analysis of the corpus is beneficial in understanding language change within a certain discourse of language at a given time.

\subsection{6) Personal voice}

One of the central responsibilities of Pacific researchers researching Pacific communities and cultures is the responsibility to establish a $v \bar{a}^{14}$ relationship with the communities they work with. This is important to ensure that appropriate recognition is paid to cultural protocols of respect. Throughout this study, I have reflected on the fa 'afaletui and corpus methodologies and their value to Pacific research and how my Samoan values of respect are prioritised or not by their logic and implementation. I offer some thoughts and comments on some of their

\footnotetext{
${ }^{14}$ Tuagalu (2008, p. 108) defines the $v \bar{a}$ as social and spiritual relations between people, is an important concept in understanding the ways that Samoans relate with one another and the world at large.
} 
differences but also their shared aims (see Chapter 7 section 7.4). My rationale for doing so is to highlight their combined value to better understanding the phenomenon of Samoan language change. I have incorporated and frame my reflections using both my cultural and academic lenses.

\subsection{0) CONCLUSION}

Though mainstream methods and methodologies continue to embrace and direct academic research, the emergence of Pacific methods and methodologies into mainstream academic research is a visible statement about the need to do mainstream research that better reflects Pacific values and contributes meaningfully to Pacific peoples' futures. Though still at the infancy stages of development, with much rigorous scrutiny needed, the evolution of Pacific methodologies that embrace the three research posts of Pacific Studies articulated by Teaiwa (2009) - interdisciplinarity, indigeneity and comparativity - is privileged in this research and underlines its methodological approach. These research posts are enhanced by the implementation of the corpus methods and methodology to this research. Both provide oral and empirical perspectives on changes to the gagana.

The next two chapters (Chapters Four and Five) initiate my search for knowledge about language change in the Samoan context. Chapter Four presents a thematic discussion about changes to the gagana Sāmoa from the perspectives of insider informants. These perspectives are complimented by a text-based examination of the gagana in Chapter Five. Both chapters address the research questions presented in section 2.18 of Chapter Two through an oral and empirical exploration and analyses of the discourses of lāuga fa 'amatai and lāuga fa 'alelotu published in the Sāvali and Sulu newspapers from 1906-2014. 


\title{
CHAPTER FOUR
}

\author{
Fa'afaletui Findings
}

\section{1) INTRODUCTION}

Pacific research needs to be immersed in indigenous epistemologies, pedagogies and methodologies (Fairbairn-Dunlop, Coxon et al. 2014, p. 47). A key purpose in Pacific research is to include insider perspectives to obtain rich contextual details allowing for multiple realities to be captured (Sanga 2004, p. 48). Multiple realities or perspectives is common in Pacific epistemologies. Samoans' perspectives on an aspect of local indigenous knowledge, such as the ' $a v a^{15}$ ceremony, for instance, vary due to the differences in localised village beliefs. Therefore, these localised beliefs determine how the 'ava ceremony is performed. Because of these multiple realities, the benefit of including insider perspectives in Pacific research acknowledges that information is not fixed or permanent (Wendt 1987, p. 82).

I have mentioned in Chapter 3 that the cultural contours of fa'afaletui have led to its development as a research methodology because it enables the researcher and research participant(s) to engage in culturally appropriate and meaningful conversations in the search for knowledge. The search for knowledge is continuous (Tamasese 2009) and needs a starting point. This chapter begins my search for knowledge about changes to the Samoan language. My starting point begins with people. It is because people speak, teach, research and are custodians of the gagana.

This chapter is a qualitative discussion from the perceptions of informed insiders. The aim is to examine their perceptions of the extent changes in the Samoan language can be attributed to social change. After fa 'afaletui with eight informed insiders, four significant themes emerged from the sessions. These are:

1. Effects of Christianity on the gagana.

2. Effects of government on the gagana.

3. Standardising the gagana.

\footnotetext{
${ }^{15}$ The 'ava ceremony is a ceremony commonly practiced to welcome visitors from one village to another. In diasporic settings, the 'ava ceremony is performed at significant events to welcome guests.
} 
4. Transnational networks and Samoan identity.

When referring to the Samoan language, I use the Samoan word gagana from this point forward in recognition of its consistent use in the fa 'afaletui. The only exception is when the word language is used by informed respondents in fa 'afaletui or when the term gagana is translated to the word language for quotes. The words church, Christianity and missionaries were used interchangeably by the insider informants. Whilst there are specific cases pointing to church as a congregation, Christianity as a religion and missionaries as people who promulgated the gospel, the terms were collectively understood to also mean foreign religion.

While the majority of informed insiders spoke in the gagana, bilingual communication was popular in the fa' afaletui. When respondents spoke in the gagana, I translated the transcript and italicised the translations. When English was the language respondents spoke in, no translation was required and as a result, the English text remained in normal character.

\section{2) THEMES}

\subsubsection{Missions and the impact on the gagana}

One of my first fa'afaletui sessions was with Ioane, a theologian who is well versed in the history of the gagana. After the usual cultural greeting exchanges, he replies when asked about the influence of the missionaries on the gagana. "E lē mafai ona ave'esea le competition lea 'o le LMS, Methodist...[ma le] Catholic" (You can't take away the interdenominational competition between the LMS, Methodist and Catholic). I am curious. What competition, I ask?

“...manatua na ōmai le 'auali'i (LMS missionaries) taumafai e cut off 'uma ties ma le Wesleyan, taimi na 'ua Wesleyan Toga, Wesleyan Fiti, taumafai e tuli 'ese 'uma ma i'inei. E le'i mānana ‘o e iai se Metotisi ma se Katoliko 'i Sāmoa. 'Auā fo'i sā manana'o e LMS 'uma le atunu'u” (Ioane). (“...remember, when the LMS missionaries arrived they tried to cut off all ties with the Methodist missionaries who were in Sämoa. At the time, Tonga was Methodist, so too was Fiji. They didn't want Methodism or Catholicism in Sämoa. They wanted the whole of Sämoa to be LMS converts. ") (Ioane).

Na taunu'u? (were they successful?), I queried: “...Ioe. Masalo pe na'o se 4-5 tausaga sā LMS 'uma ai le atunu'u. 'Ae na taunu'u mai loa le Metotisi ma le Katoliko 'ua faigatā loa le 
nofolelei" (Yes. Sāmoa was LMS for approximately 4-5 years. But when the Methodists and Catholics came back, it wasn't easy) (Ioane). The ensuing discussion provides answers to Ioane's claim of inter-denominational disharmony.

Missionary influence on the gagana began because of interdenominational rivalry for national polities. Pita, a theologian and retired educator of the gagana, adds:

“...Na ōmai le Metotisi ma le Pope 'ua 'uma ona fa'aliliu le Tusi Pa'ia ma 'ua telē le influence a le LMS, 'aemaise le Tusi Pa'ia Tahiti sā fa'aaogā e fa'aliliu ai le Tusi Pa'ia 'i le gagana Sāmoa.” ( “...When the Methodist and Catholic missionaries arrived the Bible had already been translated to Samoan using the Tahitian Bible.")

The exact dates of missionary arrivals had deserted Pita's memory, but they are LMS in 1830, Methodists in 1835 and Catholics in 1845.

When speaking on a similar topic, Ioane added to the information Pita suggested by saying that "...the gagana is a mixture of "Lalotoga, Tahiti, Kuriki, 'Eperu, 'Igilisi ma "upu Latina" (Rarotongan, Tahitian, Greek, Hebrew, English and Latin words). Ioane is referring to the influence of the Tahitian Bible on the Samoan Bible translation and gagana as a whole. He continues:

“...you can tell LMS tusitusiga...sa iai le influence 'o le Tahitian language and Rarotongan Bible 'i le taumafaiga 'o le gagana Sāmoa...'o le fesili, 'aiseā na lē taumafai ai misionare e fa'aaogā le connection lea a Sāmoa, Toga ma Fiti...manatua e tele tātou stories e link ai tātou ma Fiti ma Toga, rather than Tahiti and Rarotonga." ( "...There is a Tahitian and Rarotongan influence in LMS writings and their views on constructing a written Samoan orthography. My question is: why didn't they use Samoans' ancient connections with Tonga and Fiji, rather than Tahiti and Rarotonga?")

Ioane asks an important question. There are two possibilities. Firstly, the missionaries did not realise how different the gagana was to Tahitian, which they had learned during their time there. So to limit the time needed to learn the gagana proficiently, they used the Tahitian Bible to assist them in the translation process. Secondly, one of the objectives of colonisation was to erode the heterogeneity of Pacific languages and cultures by organising them under one nation ${ }^{16}$. The missionaries, for instance, may have perceived the heterogenous characteristics of Polynesian languages as a time consuming hurdle that would slow conversion momentum.

\footnotetext{
${ }^{16}$ The Cook Islands were organised under one nation despite their heterogenous languages and identities.
} 
These early corpus and status planning decisions by the missionaries became significant turning points in changes to the gagana because it was based on the visions of the missions and in most cases, with little or no regard of the effects on the local language and culture.

Insider informants were unanimous that the influence of the missionaries on the gagana was extensive and evident in the words used today. "Manatua fo 'i, "o le Ekalesia Metotisi a ia" (Also remember, the Methodist church), adds Pita:

“...e fa'aaogā le tausi matāgaluega, e lē ta'ua 'o se ao fa'alupega. 'O le ao fa'alupega 'o le fa'alupega 'o le LMS. E lē fa'aaogā e le Metotisi. 'O le 'upu lenā e fa'aaogā e le 'Ekālesia lenei 'o le tausi, a tofí 'o se faife'au e alu e va'ai fa'ato'aga a le 'Ekālesia e ta'u 'o le tausi fanua, tausi nu'u, tausi matāgaluega. There's a lot of Matā'upu Silisili behind that. 'O nei mea 'o evidence sa iai le 'ese'esega 'i le faiga 'o le gagana." ("...uses the term tausi matāgaluega. He [pastor] is not called an Ao 'o Fa'alupega (Head of Honorifics). Ao 'o fa'alupega is an LMS term. That is the word (tausi matāgaluega) our church/denomination uses. If a pastor is called, he is to go to tend to the plantation/vineyard of the Church. He is called planter, a village carer, a church carer. There's a lot of theology behind that...These are evidence of political/religious differences in the construction of the language.")

Very interesting point, I add. There are other words, too:

“...E 'ese fo'i le 'upu lea Toeā'ina, 'o le 'Ekālesia Metotisi e fa'aaogā le Sea, 'o le ti'ākono, 'o le 'Ekālesia Metotisi e fa'aaogā le ta'ita'i, 'o failauga fo'i ia 'o lay preachers, e fa'aaogā e le Metotisi le failauga 'ae fa'aaogā e LMS le a'oa'o fesoasoani." ( “...words like Toeà 'ina. The Methodist church uses Sea, deacons are called Ta 'ita 'i. Failāuga is lay preacher. The LMS use a 'oa 'o fesoasoani.") (Ioane).

We now know that the Methodists and Catholics coined their own words. Tina, a devoted Catholic, shares about her Catholic faith:

“...'O le mātou 'Ekālesia e fa'aaogā le 'upu Pātele. Masalo 'o le tūlaga fa'atusatusa lea 'i le Toeā'ina ma le Sea 'i le LMS ma le Metotisi. 'A'o le faife'au tausi nu'u sā ta'u 'o le fesoasoani, 'ae "ua ta'u nei 'o le Ti'ākono." ( "...In our Catholic church we use the word Pātele. I think it is the equivalent of the status of Toeā'ina and Sea in the LMS and Methodist church. But the pastor who resides in the village with the congregation was known as fesoasoani but is now known as Ti 'ākono.”) 
Missionary and mission disagreements were affecting the gagana. Because of interdenominational differences, the denominations had their respective gagana planning practices. In most cases, different words were coined for the same social role, as is evident in the anecdotes above. But during these processes, however, the gagana was suffering. Tina, in an outspoken voice, says there is "...a long history of demonising indigenous words." For example, “...nofotane and faiavā, e lelei "upu!" (the words for in-laws are clean words) (Tina). Once held in high regard, the roles of nofotane and faiava $\bar{a}$, as in-laws, became subordinated positions during missionary occupation. This was because missionaries were astonished at the deference accorded to women and girls in Samoan culture, something perhaps foreign to them at the time.

While new words were being added, meanings shifted. This was all taking its toll on the gagana. Samoan words that were unmarked by Samoans became victims of moral judgement by Western clergy, exclaims Ioelu. "O tūlaga 'o le 'upu fa'aipoipoga 'i le fa'asāmoa...e tatau fo 'i ona fa'aaogā le 'upu feagaiga, 'auā 'o le covenant" (In terms of the Samoan word for wedding, the word feagaiga (covenant) should be used, because it is a covenant") (Ioelu). Ioelu, a theologian, pastor and educator, speaks from his experiences of officiating at Samoan weddings. Ioelu believes the word fa 'aipoipoga needs to be decolonised and replaced with the pre-Western word feagaiga. For him, fa 'aipoipoga has no meaning and value to Samoans. When I asked him about the value the word feagaiga would provide instead, he is adamant in his reponse:

“...a fa'aaogā le 'upu feagaiga (covenant), e take serious ai e le tagata le uiga o le feagaiga...e iai le fear fo'i lea 'ona 'o le covenant 'ua osi...pei e lē mamafa 'i tagata le "upu fa'aipoipoga." ("...if the word feagaiga is used, people will take it seriously because of its indigenous meaning...it brings fear (reverence) to the relationship because it is a covenant...the word fa'aipoipoga does not carry any weight or importance.")

Ioelu later adds an intriguing account about the correlation between terminology and practice, and how both can be excluded and considered inferior. He contextualises:

“...O le fa'aipoipoga e lē ta'ua 'o se sacred ceremony. E lua lava sacred ceremony (sic) 'i totonu 'o le lotu. $\mathrm{Na}^{\prime}$ o le papatisoga ma le fa'amanatuga. 'A'o le fa'aipoipoga, leai la, e "ese lona fa'aaogāina e le Ekalesia.” ( “...Weddings are not called a sacred 
ceremony. There are only two sacred ceremonies in the (Samoan) church. Only baptism and communion. But weddings, no it is not, the church uses it differently").

Ioane, Pita, Tina and Ioelu question language motives of the missionaries and are particuarly appalled at the effects it had and continues to have on the gagana. It is clear that status and corpus planning was intentional. My question, proclaims Ioane, is:

“...'ua lē lava 'upu Sāmoa?...Tai pei ‘o la'u finauga na 'i le 'upu nunuavaga. They didn't like it at all, because it's connected to virginity culture...pei 'o le māfua'aga lenā na lē fa'aaogāina ai le 'upu nunuavaga, because its associated with the culture, a'o le 'upu ia, it's not about that, so 'o le 'upu 'i le taimi nei, 'ua pei 'o se 'upu leaga le avaga, 'ae 'ou te fai atu, na demonise e misionare some of the clean words, because they are against the Christian principles. Tele fo' $\mathrm{i}$ ia 'o a'afiaga 'o le gagana 'i lenā mea. $\mathrm{Na}$ fo' $i$ 'ou te finau 'i le 'upu e fa'atatau 'i le circumscision, pei a 'o se 'upu sā, 'ae lē 'o se 'upu sā." (“...were there not enough Samoan words?...It's like my argument about the word nunuavaga [indigenous term for wedding]. They didn't like it at all, because it connected to virginity culture...that is the reason why the word was no longer used. But the word is not about that. So today, the word avaga (outside of wedlock) is like a bad word. But I assure you, some Samoan words were demonised by the missionaries because they felt the words were against Christian principles. As a result, there are a lot of repercussions because of it. Even my argument about the word circumscision in Samoan (peritomeina), it's like a bad word now, but it isn't.") (Ioane)

Evidently, status and corpus planning was intentional and affected the gagana greatly through the introduction of new words while subordinating existing ones. Fa'afaletui then lead to the next theme, the influence of administration and government on the gagana.

\subsection{2) Administrations and government: reflections about language planning}

“...:I don't think e telē se influence a administrations" (I don't think the administrations had much influence on the gagana), was the general feel of views by informed respondents to the question: was there much influence of the administrations on the gagana? Mose, a ti 'ākono and cultural expert, explains why: 
“...'auā na ōmai 'ua iai ā'oga a le lotu ma le Talalelei” (I don't think the administrations had much influence on the gagana because when they arrived there were already mission schools and Christianity) (Mose).

Like others, Mose was honest about his limited understanding of the administrations and their time in Sāmoa. But Saga, a long time educator, is clear when she says: "They were very influential! Though the church has provided a lot of borrowed words/derivatives, the state have their own translations and new words coined to provide for new concepts/words and ideas." She adds:

“...You see, groups in Sāmoa can decide on their own translated words and variations occur, for example, the Catholics use Petelo ${ }^{17}$ while the Congregational (formerly LMS) use Peteru. Same as the words komenio and fa 'amanatuga. Where the Catholics use komenio and the Congregational church use fa 'amanatuga for church communion. Even the government ministries do their own words when needed. It's a lottery! (sic).”

I wanted Saga to say more. After a thoughtful pause, she continues:

“...'Upu nonō (Borrowed words)! There are so many...originates from administrations time in Sāmoa. Not really German, but English words. I'm not entirely sure how many, but there is possibly some words we still use that have German influence. All I know is there are a lot of English words. You just have to hear the sound and know its English"

It did not strike me at the time to follow up with Saga why she thought there were so many 'upu nonō in the gagana. But I learned from it and asked another insider informant the question: why do you think there are so many 'upu nonō in the gagana? Ioelu is attentive and responds:

“...'auā 'o tātou e alu le taimi 'o tusi, a'o tātou ia 'o le gagana fa'alogo lava, 'auā 'o tâtou fo'i e 'ese le vave o lā tā pu'e, fa'alogo, e o'o 'i mea 'ou te alu ai...'a fa'alogo ma pu'e, e fiu e toe ave'ese, e lē mafai 'ona toe 'ave'esea...leaga fo'i o le mea lea tā te faia, tusa lea tătou te asamo." ( "...because for us it takes too long to write, we are used to the art of listening, because we are good at it, especially when we go places...if you listen and remember, you won't lose it, it stays with you...remember because what we are actually doing is engaging in the pursuit of knowledge”)

\footnotetext{
${ }^{17}$ Transliteration for the English word Peter.
} 
Ioelu's comment about Samoans' art of listening is intriguing and has made me ponder these questions: did, and if so to what extent, our people, through the art of listening assist in the integration of foreign words? Did the missionaries realise this and use it as a tool for gagana planning? None of my insider informants had the opportunity to answer my questions because our fa' afaletui did not lead us that way, nor did I think about it at the time. But what really heated up the responses from informed insiders was the current lack of government priority for the gagana.

"I am concerned" (Pita). After querying why, Pita responds:

"E lē 'o fa'atāuaina e le mālō le gagana...'auā 'ua fa'amuamua isi mea e pei 'o faigapā'aga ma isi atunu'u e pei 'o Saina, mea tau tupe ma atiina'e" (Language is not a government priority because they are prioritising other things such as international partnerships with countries such as China, economics and development).

The 2014 Samoan Language Commission, though a good initiative, is not valued. "...'O le language commission (reference to the language commission introduced in 2014)...e lē 'o ano ai le mālō" (The government have turned a blind eye on the language commission) (Ioelu). One of the reasons why the commission does not seem to have worked is that multiple stakeholders have different ideas. Ioane clarifies:

“...Talu 'ona fai a mātou fono, e faigatā matā'upu 'ona e 'ese'ese finagalo 'i le gagana, 'ona fo'i 'olo'o iai faife'au, 'o faiā'oga, 'o le 'autōfā mau, sui 'o le 'ofísa, ma isi (Since we've had our meetings, everyone has a different take on what is needed for the language, because there are pastors, teachers, elders, ministry representatives, and others) (Ioane).

Tina, who has been teaching the gagana for many years, says that "they (government and ministry) are too heavy on culture rather than gagana. They need to prioritise the Samoan language first, especially the phonetics." Tina extends the discussion by saying:

"...they need teams to study the language. There is a need to fuse language teaching with cultural teaching. This is linked to the increasing need to prioritise and create specialists in etymology. For example, the words samigāsili and saunigalotu are one word in etymology, rather than two separate words as constantly used by many Samoans. These mistakes appear to be an unawareness of Samoan grammar" (Tina). 
Generally, the influence of administrations on the gagana is acknowledged in the views presented. The lack of priority given to the gagana by the current government is evident in the need of gagana specialists actively researching the gagana. This next Section is an extension of the government's lack of priority given to the gagana, where perceptions are targeted at language standardisation.

\subsection{3) Standardising Samoan}

The lack of a standardised gagana is an influence "of the missionaries and administrations," says 'Ina, a Samoan academic and cultural expert. She continues:

“...It's because 'o le lotolotoi 'o tagata mai fafo, ma sā 'ese'ese 'uma a lātou mana'oga mo Sāmoa. 'O misionare sā manana'o e fa'atalalelei le atunu'u, 'ia which 'o se mea lelei. Ōmai Siāmani lātou, e 'ese fo'i, fa'apenā ma Niu Sila. 'O nei tagata 'ese ma a lātou fo'i mea na fai, 'ua fai ma mea 'ua lē mafai ai 'ona fa'a'aupitotasi le tusitusiga 'o le gagana. 'Ona fo'i e le'i tâua 'iā lātou ia vaega, pau le mea na lātou manana'o e fai 'o le fai mo lātou le atunu'u." (“...It's because there were foreigners, who all had different wishes for Sämoa. The missionaries wanted to Christianise the country, which is a good thing. The Germans they had something different, so too did the New Zealanders. These foreign peoples and what they did, it contributed to the nonstandardising of the language. Because standardising the language was not important to them. All they wanted was to have the country as theirs.")

That is why, says Tina, “...there is no standardised gagana.” In saying that, Tina is adamant that these issues need to be sorted so that the "...written word...match[es] the spoken." The orthographic variations in the language "need to be corrected...(because)...the media, print, such as newspapers, posters and advertisements...do not match" (Ina). But do others agree? Sina provides her perspective:

“...It's really tricky when you are in education...because you feel like you have to have it

standardised because what are you going to mark against, like that's why, in that sense, but to me, quite personally if students are using it, then that's more important than saying what's right or wrong, but if we are going to mark writing on grammar, but then again, who cares about grammar right?" 
Tina agrees with Sina when she adds:

“...If you read some of the student's writings it's got this really nice flow to it. Whether they spell olo'o [tense indicator] together or not, it just has a real natural feel to their writing. Then you have the kids who you are teaching these tenses, it just doesn't have the fluency...it limits them, when [we] put those structures to it, like the Bible translation, that's more natural, you get more natural language that way, I'm just thinking back to students when they have to submit pieces of writing, students from Sāmoa, you don't have to scaffold them because they have a big bank of words, so they write freely, but the students here need more of a template, but that isn't as real, its very much rote learn."

Sina, who's response is based on her teaching of the gagana in New Zealand, signals the difference between language acquistion in Sāmoa, where the gagana is the language of society, as opposed to New Zealand where it is a second language. While the gagana may be spoken in the home in the diasporic setting, it is not the dominant language of society.

The politics of standardising the gagana is reflected in the contextual differences of where the gagana is spoken and learned. However, with an increasing number of diasporic Samoans, the formalising of diacritical marks in the gagana is regarded as important:

“...It's helpful. Especially for...students here in NZ to be able to distinguish the meaning of words, because if you were to just write 'äiga (family) and 'aiga (feast), students who don't have as much vocab wouldn't know the correct pronunciation in its context. Its good for tamaiti (children) coming through to make it a habit, because they don't have enough vocabulary, and using the glottal and the macron helps them to be able to, so this word, means a lot of different things, and they begin to know the context of when to use the words, but not being able to identify words without it because its a skill they acquire after they have a lot of words in their vocabulary bank." (Sina)

Overall, the perceptions of insider informants speak in favour of standardising Samoan. This raises the question of whether standardising the gagana ignores the shifting and expanding communities of where the gagana is used, and the communities of where the people who speak it are situated.

\subsection{4) Transnational networks and Samoan identity}


The shifting, expanding and interconnected network of Samoan communities has become a system for linguistic and cultural preservation and change. Speaking about Samoan village fa' 'alupega (salutations), Ioelu believes that the diasporic church is a place where knowledge of the Samoan gagana and culture is nurtured and extended:

“...Ioe, 'o le nu'u i'inei 'o le 'Ekālesia...maua 'uma lava 'i totonu 'i'î. E pei la 'o le tusigāigoa lea na fai, 'o fa'alupega 'o le faletua, le fa'afeagaiga, fa'alupega 'o le nu'u. 'Aemaise fo'i isi faife'au. 'Āfai e to'atolu isi faife'au, e o'o ā 'i ai. 'Ona 'o lea 'ua lē 'o se nu'u se tasi, a'o Sāmoa 'ātoa. 'Ua tele ai fo'i ma la tātou 'atoponapona lea 'ole'ā fau ai a ma fa'aputu 'i'ī. 'Ia 'o fea lava le mea e lāgā ai le suafa lea, a'e 'ua iloa, e sau mai '̄ ma 'ํ. Tasi a lau fa'alogo, e iloa fa'alupega." ( "...Yes, the church is the village here (New Zealand)...you can find it all in church. Like the village fundraiser we had, (we had to memorise/know) the pastor's wife's village salutations, the pastor's, the village salutation, other pastors who were present...it is because we are no longer one village, but the whole of Sämoa. We end up knowing a lot and store this knowledge wherever we go.")

Like the church, the family domain plays an important part in this network of gagana and cultural preservation. Saga shares:

“...It depends on the home environment, trying to have that authentic environment. But it depends on your parents, the language they brought, they already had a rich bank of language. So the home environment e tāua tele (is very important)."

The church and family environments, particularly overseas, are central to the transnational network of Samoans. It is within these domains that the persistence of Samoan identity is fostered. In what way, I ask Ioelu:

“...Na āfua mai lava 'i totonu 'o le loto'ifale... 'Aemaise le vā 'o a'u ma lo'u tuafafine. 'O le vā 'o a'u ma lo'u tamā, ma lo'u tinā... 'o le fa'atūlagaina 'o le gagana 'o le vā...le 'aufaigaluega, 'aemaise fo'i $\bar{e}$ 'o fa'auluulu 'iai matāgaluega ma so'o se mea... 'O le mea lenā e 'ese ai a Sāmoa. 'O lana aganu'u ma lana gagana. 'Aemaise le vā tapuia 'o le tagata. A tu'u mai 'i le falesā, 'o le aganu'u ma le fa'akerisiano, e lē tatau ona separate. 'O le mea lenā e mālosi ai le tātou aganu'u, ma le tātou agaifanua, ona 'olo'o base "i le Tusi Pa'ia." ( “...(The language) was created from within the confines of home and family...Especially the sacred social space between me and my sister. The sacred social space between me and my father, and my mother...the is the structure of the 
sacred social space language...the clergy, especially leaders of associations and others...That is why Sämoa is unique. Her culture and language. Especially the sacred social space between people. In the context of church, the culture and Christianity, it cannot be separated. That is the strength of our national and local cultures, because it is based on the Bible.")

Ioelu is reflective of the intricate relationship between the culture and gagana, as pillars of Samoan identity, which are nested in 'āiga (family) and 'ekālesia (church). "O le 'upu moni”, believes Mose, “...e lē mafai ona toe 'ave"esea le tātou matūpalapala mai le Atua” (our blessing from God (language) cannot be taken away from us. ”). I sense from Mose a feeling of language sacredness perpetualness. I let Mose continue:

“...'Ua 'uma fo'i ona tu'umāvaevae e le Atua mea 'uma. 'O le tagata ma lona 'āiga, lona nu'u, lona tupu'aga...[E] mālosi le aganu'u. Ma le ō fa'atasi ma le lotu.” ( “... In my opinion, our gift [language] from God can never be taken away...God has organised everything. Every individual has a family, his/her village, his/her origin...The culture is strong. Especially in conjunction with church.”).

But even theses sites as cultural and linguistic nests are constantly changing:

“There isn't much language being spoken at home, or in most churches. Even the culture is being lost because of it. People don't say tūlou anymore, so don't know the cultural meaning and what it looks like."

Generally, though Samoan identity remains strong and is strengthened in many ways by transnationalism, Samoan identity continues to change, just like all cultures and languages continue to do.

\subsection{5) Language Change}

This section is an extension of the perceptions of informed insiders. The perspectives here expand further on informed insider's perceptions of language change.

"To me, Samoan language change is okay-e aogā suiga (change is useful)", comments Tina. But change needs to be appraised and remain rooted to the past, contests Sina. She explains:

“...I know how it's important to change, [but] why are we not trying to reclaim things [words]...rather than trying to create new words...there will be so much benefit looking 
to the past. Wouldn't it be really good for language...To be able to describe to them [students] that's a great way to teach the language, you learn more vocab...than trying to transliterate it...We have a lot of rich knowledge, but its only getting lost because we want to change with the times, and no-one is trying to reclaim what it is we've left in the past. A language wouldn't die if we just su'esu'e mea na iai (research what we had)... we need to promote the beauty the way it was.

What linguistic beauty do you talk about?, I interrupt:

"...see upega 'o feso'ota'iga (internet) is way better than 'initineti [transliteration of internet], because it has the word upega (net) and students can learn that word is an indigenous term. Even the word tausoga (cousin), kids don't use that now, its always kāseni [transliteration of cousin]."

Again I interrupt, but this time in consensus. Sina approves and continues:

"...To me, if we are accepting those terms, and there is already a word for it, that's not good. I think people have become lazy...Samoans are in contact all the time. It is society who want easy things...thats the problem with technology too...Change can be changing our mindset to revitalise...the words we had, that's change.

Sina continues, but let me provide foreground by saying that her next comment is intriguing in that she, like Ioelu earlier, also talks about the word fa' aipoipoga, where she offers a different word alternative to the word feagaiga suggested by Ioelu:

“...See I'd like words like fa 'aipoipoga [post-missionary word for wedding] be used with nunuavaga which was the pre-Christian term. I think terms can co-exist...It'll be nice for people to know those words...It's not that we will be going against religion, its about embracing the breadth of our vocabularies."

Sina brings forth two major points. The first point is to do with transliteration. Personally, I have always considered transliteration an adaptive and survival attribute of the gagana. Sina's second point is about gagana revitalisation. She suggests a decolonised approach to gagana by excavating indigenous words left in Samoa's colonial past. Her approach is to be able to reconnect history and contemporary Samoan. What this does is enrich both gagana and history. Pita adds: 
"It's about time we sit down fa'aaogā le Tusi Pa'ia as a resource, 'ae toe fai se mea mo le gagana Sāmoa...there comes a time e toe nonofo ai 'i lalo ma toe iloilo la tătou gagana...e lē tatau 'ona tātou toe fa'alagolago 'i le Tusi Pa 'ia, 'auā e tele ona vaivaiga."

“...It's about time we down and use the Bible as a resource, and do something for the language...there comes a time to sit down and assess our language...we should not rely on the Bible anymore because it has its limitations."

The subordination of the gagana under the influence of both foreign words and concepts remains very much alive (Ma'ilo 2016). As a result, pre-Western words such as nunuavaga were considered unfit for social changes based on the missionaries interpretations of the existing semantics and cultural practices. To excavate paganised terms and to raise the idea of the Bible having limitations will probably not be taken well, and if it was, will take some time. Which brings me to think about whether transliteration is a colonial residue in the gagana? The idea that transliterations are becoming detrimental against the use of existing words is worth exploring. A detailed account of this argument is provided in section 6.3.2 of Chapter Six.

\section{3) CONCLUSION}

The objective of this chapter was to investigate insider perceptions of the extent that social change influences gagana change. The shared beliefs of insider informants have indicated that social changes introduced by foreign contact have had immense influence on the Samoan lexicon. The perceptions expressed here point to some important shared beliefs.

Evangelisation and government are the two instrumental foreign institutions that have initiated immense changes to the gagana. According to the perceptions of insider informants, both have co-existed with fa 'asāmoa (Samoan culture) and have shaped Samoans' religious, political, cultural, social and language beliefs. Religious and government ideologies were channelled through proselytisation, literacy and education. Sāmoa was restructured resulting in a blending of the old and new. Through literacy and education, language planning validated the restructure. At the same time, Samoa's ancient contact with neighbouring Pacific cultures and languages became a thing of the past as Samoans entered a new chapter of contact and change.

The social and linguistic restructuring of Sāmoa was amplified with the rise of transnational mobility. These movements, of course, were forced responses to economic and political pressures. There, Samoan communities were established and grew, often replicating their ways 
of life in their new surroundings. Samoan mobility resulted in the establishment and expansion of a transnational network of people connected by heritage. Whilst many Samoans maintained connections to home, some did not. Others were caught between cultures. For a lot of Samoans, this became a recipe for unsettling experiences of gagana and culture, particularly for children of the diaspora. Through their expanding mobilities and evolving identities, Samoans have used this transnational network to retain a connectedness and preservation of their gagana and culture.

The evolution of the transnational network has also created replicating enclaves of Samoan religion and culture. These enclaves have become the driving force behind the persistence and survival of the gagana and culture. The marriage between Samoan culture and church give it strength.

In all, the influence of Christianity and government remain. The gagana and culture continues to be contracted and enriched. But the need to standardise, decolonise and revitalise the gagana remains important.

The next chapter (Chapter Five) is the corpus findings chapter. It is an extension of the views of informed insiders presented here. Equally important, it is also a continuation of my search for knowledge about Samoan language change. 


\title{
CHAPTER FIVE
}

\author{
'UPU NONŌ 'I LE GAGANA
}

Foreign types (words) in the Samoan Language

\section{1) INTRODUCTION}

This chapter presents the corpus findings from the Sulu and Sāvali files. The Sulu and Sāvali files are used to represent two discourses in the gagana. The first discourse is the fa 'amatai (chiefly language) which is represented by the Sāvali. The second discourse is fa'alelotu (religious or Church-driven) and is represented by Sulu. Both the Sulu and Sāvali were examined for foreign types which were incorporated into the corpus.

From the four indicator years of 1906, 1944, 1977 and 2014, a corpus of 1,975 unique types were identified from lāuga sources in both the Sulu (1,007 foreign types) and Sāvali (968 foreign types) newspapers.

From these figures, 11,930 tokens were counted for both Sulu and Sāvali. Of the 11,930 combined tokens, 5,478 tokens are attributed to Sulu while 6,452 tokens were attributed to Sāvali. A more in-depth analyses of these figures will be provided throughout this chapter.

There are a number of sections and sub-sections in this chapter. Sub-section 5.1.1 addresses key terms used throughout the chapter. Sub-Section 5.1.2 explains findings sequencing. Brief historical and file descriptions for both the Sāvali and Sulu are presented in Sections 5.2 and 5.3. Category classifications are then looked at in Section 5.4. An examination of the corpus findings will follow that comprising of Sections 5.5 to 5.12. An analysis of the findings is presented in Section 5.13, followed by the Conclusion in Section 5.14.

\subsection{1) Key terms}

Some key terms used throughout this chapter require transparency. The word type is used to mean word. Token is used to refer to the frequency of a type. Both are linguistic terms used in corpus analysis. The word file is used to mean newspaper. The phrase Sulu Sāmoa is shortened to Sulu. The term Sāvali is unchanged. 
The term Sāmoa is spelled in a number of ways. When referring to the country it is spelled as Sāmoa (with the macron $\bar{a}$ ). This acknowledges it as an indigenous word. When referring to ethnicity in a Western sense the macron is removed and the term is spelled Samoan.

\subsection{2) Corpus findings sequencing}

The corpus findings sequencing takes the following order: (1) Sāvali findings; (2) Sulu findings. All findings will be presented by indicator year (1906, 1944, 1977 and 2014). The discussion of themes will be presented as follows:

1. Place names $(\mathrm{PLN})$

2. Proper nouns $(\mathrm{PN})$

3. Religious culture

4. Social culture

5. Material world (MW)

6. Natural environment (NE)

7. Other

(OTH

\section{2) SĀVALI FILES (1906-2014)}

\subsection{1) A short history}

Since its first publication in September 1905, the Sāvali has been the responsibility of a number of publishers. The German administration, for instance, published the Sāvali from September 1905 to August 1914. The New Zealand administration then took over until 1 January 1962, when Sāmoa became an independent state. Since then, the Samoan government has continued the publication of the Sāvali as a government owned and managed newspaper.

The commissioning of a government newspaper was regarded as important because it allowed direct communication between the administration and the local population. The newspaper was published in both the gagana and German during the German period. The administrations used Samoan translators to translate administration notices. There were also contributions by Samoan matai and clergy, which were in the main about religious fundraising events. Since the New Zealand administration took over, the newspaper continued its bilingual format, but this time instead of German and Samoan became Samoan and English. 


\subsection{2) 1906, 1944, 1977 and 2014 files}

The 1906 issues were acquired from the Sāvali Main Office in Apia. Unfortunately, only seven issues were retrieved (February, March, April, June, July and August). The unaccounted for issues were either not stored or lost. Unlike the 1906 issues, the full 1944 files (Jan-Dec) were located and accessed at the Sāmoa Lands and Titles Court (SLTC) in Apia.

Both the 1906 and 1944 files were bilingual. The 1906 files were in both Samoan and German, whereas the 1944 files were in Samoan and English. The bilingual texts were published in each newspaper using different sections. A range of notifications were published in these issues ranging from governance, civil laws, curfews, acts, ordinations, weddings, funerals, church fundraisers (tusigāigoa), leases, health, education and international events. The average length of each issue was six pages.

The 1977 files were also bilingual (Samoan and English) and covered a wide range of press releases. But what differed from the 1906 and 1944 files to the 1977 files was the frequent publishing of parliamentary speeches, land title court cases, classified advertisements and photographs.

By 2014, the Sāvali was published on a weekly basis and comprised of separate Samoan and English editions. The Sāvali is the leading Samoan newspaper for some. As copies were shipped to New Zealand and Australia, increasing requests for an online presence by overseas news readership led to its online accessibility today.

Coverage in the 2014 Sāvali is very broad. Sports sections, letters to the editor, opinion pieces, recurring columns and sponsored content were now the norm. Because it was a government newspaper, most of Samoa's prime minister's speeches and Q \& A sessions are published and so are publically accessible.

\section{3) SULU FILES (1906-2014)}

\subsection{1) A short history}

At the outset, the Sulu was published in London by the LMS until 1839 when a printing shop was set up in Sāmoa. Up until then, publications were shipped to Sāmoa from London. The first publication was in 1836 in the gagana. The original is today shelved at the Turnbull Library in Wellington. Over the years, Sulu continues to be published in both the gagana and 
English in a single issue. The LMS's publishing of Sulu ended in 1921, when the Samoan church became self-governing. Since then, the Sulu has been published by the Congregational Christian Church of Sāmoa (CCCS).

Unfortunately, there is no single storage facility where Sulu are held. Today, the initiative to locate and store past issues remains in its infancy stages. There are very few Sulu stored at the Mālua Theological College (MTC) or the Sulu Office in Apia, both are CCCS sites. Copies of past Sulu have been found at MTC, Sulu Office, National University of Sāmoa (NUS) library, Turnbull Library or in the possession of pastors and congregants. From 2011, copies of Sulu have been archived on pdf format and made accessible to the public via MTC's website.

\subsection{2) 1906, 1944, 1977 and 2014 files}

Sulu copies were obtained from various locations. The $1906 \mathrm{Sulu}$, for instance, was located at the NUS library. The Sulu 1944 files were located at the SLTC in Apia. Sulu 1977 I purchased from the CCCS bookshop for $\$ 10.00$. Finally, copies of Sulu 2014 were stored by the Sulu Office. Apart from Sulu 1977, all files in the possession of the researcher are copies of the originals.

Not all Sulu issues were obtained, however. Table 7 provides an outline of the total number of monthly issues included in the corpus:

Table 7:

$\underline{\text { Sulu and Sāvali Issues Obtained }}$

\begin{tabular}{|c|c|c|c|c|}
\hline $\begin{array}{c}\text { Indicator } \\
\text { Years }\end{array}$ & Sāvali & Total & Sulu Sāmoa & Total \\
\hline \multirow{1}{*}{$\mathbf{1 9 0 6}$} & $\begin{array}{c}\text { Jan-Dec } \\
\text { (missing Jan, May, } \\
\text { Sept, Oct, Nov and } \\
\text { Dec) }\end{array}$ & 7 issues & Jan-Dec & 12 issues \\
\hline $\mathbf{1 9 4 4}$ & Jan-Dec & 12 issues & $\begin{array}{c}\text { Mar-Oct } \\
\text { (missing Jan, Feb, Nov, }\end{array}$ & 8 issues \\
\hline $\mathbf{1 9 7 7}$ & Jan-Dec & 12 issues & Jan-Dec & 12 issues \\
\hline
\end{tabular}




\begin{tabular}{|c|c|c|c|c|}
\hline \multirow{2}{*}{2014} & Jan-Dec & $\begin{array}{c}28 \text { issues } \\
\text { (missing } \\
\text { issues 21-24) }\end{array}$ & Jan-Dec & 12 issues \\
& & 59 Monthly & & \\
\hline \multirow{2}{*}{ Total } & & Issues & & Is Monthly \\
& & & \\
\hline
\end{tabular}

\section{4) CATEGORIES}

To make sense of the corpus, categories were created based on the make-up of types. Because of the extensive number of foreign types found in the corpus, seven categories were determined that encompassed all types. Each category is abbreviated in parentheses and the abbreviation will be used throughout this chapter. Category definitions were developed based on the profile of foreign types comprised in the corpus.

Place Names (PLN): $\quad$ Comprises all country, city, suburb, ocean, sea and mountain names.

Proper Nouns $(P N)$ : $\quad$ Proper nouns are inclusive of all deity, people, institutional and book names. Months and days of the week are also included.

Religious Culture $(R C)$ : This category included all types that specify a position or role in the church or religion as a whole. All tangible and visible types with a religious connection, such as malumalu (church building), were categorised under Material World.

Social Culture (SC): $\quad$ All types associated with secular human interactions and roles in society were categorised as social culture. These included sports and numbers.

Material World $(M W): \quad$ All tangible and visible types were categorised under Material World. These include money, clothing, buildings, and tools. Also included in this category were people related non-proper nouns. An example is pepe (baby). 
Natural Environment (NE): Types that represented flora and fauna were included in this category.

Other $(O T H): \quad \quad$ All types which did not fall under the above six categories were interpreted and categorised as Other. All types in this category were verbs.

While the majority of types were easily categorised, some types had more than one possibility. Types such as tusi pese (hymn book), for instance, could be categorised under Religious Culture, Social Culture or Material World. In such cases, collocational information was used to determine the accurate category.

The distinctions between capitalisation and non-capitalisation was another issue. The noncapitalised type kilisimasi, spelt Christmas in English, is an example. Several steps were taken to identify the correct category. For example, because kilisimasi is not capitalised in the corpus, it was interpreted as a non-proper noun. The next step was to find whether it fit the RC or SC category. In the end, the origins of the type was prioritised, making kilisimasi a RC type.

With category distinctions transparent, Sections 5 to 13 provide an analysis of types and tokens per theme for the respective indicator years.

\section{5) SĀVALI 1906 FILES}

Table 8 presents a categorical break-down of foreign types and tokens for the file: 
Table 8:

Categories/Types/Tokens: Sāvali 1906

\begin{tabular}{|c|c|c|c|c|}
\hline \multicolumn{5}{|c|}{ Sāvali 1906} \\
\hline Categories & Types & $\%$ & Tokens & $\%$ \\
\hline 1. Place names & 10 & 9 & 23 & 4 \\
\hline 2. Proper Nouns & 29 & 27 & 146 & 25 \\
\hline 3. Religious Culture & 15 & 14 & 57 & 10 \\
\hline 4. Social Culture & 29 & 27 & 292 & 50 \\
\hline 5. Material World & 20 & 19 & 54 & 9 \\
\hline 6. Natural Environment & 3 & 3 & 3 & 1 \\
\hline 7. Other & 1 & 1 & 5 & 1 \\
\hline Total & 107 & $100 \%$ & 580 & $100 \%$ \\
\hline
\end{tabular}

\subsection{1) Table 8 Analysis}

Because of the limited total of Sāvali 1906 issues located, coupled with a low average of total pages per monthly publication, the types and tokens for this file are fairly low. Nonetheless, PNs and SC are the two most dominant categories for types and tokens. While the majority of types congregate around the PN, SC, MW and RC categories, types in the SC category are the most frequently used (292 tokens).

\subsection{2) Place Names}

Two geographic areas are represented in PLN. These are Europe and the Pacific. Europe is represented by the types Siamani (Germany -8 tokens) and Perelini (Berlin -5 tokens). These tokens were also the most frequently used. The Pacific is represented by the types Pasefika (Pacific -2 tokens) and Toga (Tonga -1 token). The frequent use of Siamani and Perelini is indicative of Germany's administering of Sāmoa at the time. Collocations of these two types were mainly used in phrases referring to Germany's strong position amongst the world's leading powers of the period. Pasefika and Toga were collocated to refer to nationality (e.g. tagata Pasefika (Pacific people) and ali ‘i Toga (Tongan man). 


\subsection{3) Proper Nouns}

Types in this category were organised into the sub-categories of people names, deity names and months of the year. Though people names (14 types) and months of the year (12 types) accounted for the majority, deity names, with only three types (Ali 'i, Atua and Iesu), were used more frequently. The type Atua, for instance, appeared 75 times. Atua is one of the most frequently used types in 1906. One of the reasons for this was the influence of the Bible as the main source of lāuga fa 'alelotu. The types Ali' $i$ and Iesu received only four and two tokens respectively. Of the people names, the type Viliamu (Wilhelm) was used the most with eleven tokens. This was probably because this was the given name of the Kaiser. It is also highly possible that the high frequency of Viliamu was a result of people naming their children after the pioneer missionary Williams.

Interestingly, the only people name with German origin is Feterika (Friedrich). The name Viliamu is the translation used for the German name Wilhelm but follows the British translation introduced earlier by the LMS missionaries in Sāmoa for the English lexical equivalent of William. Additionally, the german type Franke does not take Samoan orthography form and is instead used as is. However, there are not many cases of this throughout the corpus as the majority of foreign words take Samoan orthography.

\subsection{4) Religious Culture}

By 1906, Sāmoa had already been deeply immersed in Western Christianity for over seven decades. Therefore, the majority of religiously associated types that appear in Sāvali 1906, predate German arrival and were constructed with missionary influence. Types such as lagi (heaven), lotu (church), mālamalama (Christian) and sauniga (church service) are some examples.

Nonetheless, RC types accounted for 14\% (15 types) and 10\% (57 tokens) of total types and tokens for the file. The general make-up of types in this category exemplified spirituality. These included types associated with religious services and roles. The most frequently used type was galuega (vocation-11 tokens). As indicated by the phrases galuega lea a le Agaga Pa ia (the role of the Holy Spirit) and fa 'amāoni 'i le galuega (to be a diligent servant in the ministry), there was an awareness by the German administration of the importance of religion and 
spirituality to Samoans. As the new administration, their immersion and understanding of Samoans became a strategic alignment of their governance of Sāmoa.

\subsection{5) Social Culture}

The SC category consists of 27\% (29 types) and 50\% (292 tokens) of the total foreign type and token distribution for Sāvali 1906. The predominance of types reflecting governance roles is obvious in this category. With the most types, types such as mālo (government -59 tokens), kōvana (governor-48 tokens), kaisalika (imperial-18 tokens), kaisalina (empress-3 tokens) and tūläfono (government law, policy or act-11 tokens) are some examples. These types were associated with German administrative positions and influence.

Of great significance are words with German origin which have taken Samoan orthography. Some examples include Kaisalina from the German word Kaiserin (18 tokens-empress), Kaisa from the German word Kaiser (5 tokens) and Ametimani from the German word amtmann (1 token-German official). The word amtmann is now archaic in the German language (Millington, 2019).

Other types such as ali ' $i$ sili (head of native administration- 8 tokens), faipule (village/district mayor-36 tokens) and pulenu' $u$ (village mayor -4 tokens) are interesting because these positions were created by the Germans in their construction of a native administration. The establishment of a native administration was a tactic to dismantle the indigenous authority, namely the Tafa'ifā, holder of all four of Samoa's paramount chief titles of Tuia'ana, Tuiatua, Gato'aitele and Vaetamasoaali'i. An additional position created as part of the native council included ali ‘i tôfia (government official—11 tokens).

As a result, the formalising of the newly created German and indigenous positions was solidified when the positions were formalised and integrated into Samoa's honorifics. The types mālō, kōvana, kaisalika and faipule, for instance, replaced the traditional offices of Tümua and Pule in the pre-Western version of Samoan honorifics.

The types and collocations in this category reflect prevailing notions of government power and law. It is clear that although the Germans approached governance of Sāmoa using the local culture and existing indigenous words (Lang 2002, p. 12), German office names such as faipule, which if unpacked means to conduct (fai) authority (pule), does point to the 
deliberateness of German language planning and manipulation of the gagana as a governing tactic to establish the acceptance of the German administration.

\subsection{6) Material World}

MW related types accounted for 19\% (20) of types and 9\% (54) of tokens. Types in the MW category were predominantly aligned with wealth, education and communication.

Tusi (book) was the most frequently used type with 21 tokens. But it also had other lexical expansions such as tusi tagi (letter of appeal-2 tokens) and tusi tôfiga (letter of appointment1 token). Like tusi, the appearance of tusi tagi and tusi tôfiga are interesting because it reflects how writing and communication were changing society through the introduction of new social roles and practices. Other lexical expansions of the type tusi were found in Sulu, such as Tusi Pa 'ia and Tusi Sā (both meaning Bible) and Tusi Pese (hymn book). The evolution of the type tusi, however, reflects the dependency on written letters for communication between the German administration and Samoan population at the time.

Tălā (dollar) was the next most frequently used type with 14 tokens. Other types included 'auro (gold-2 tokens), 'ārio (silver-5 tokens), tupe (money-4 tokens) maka (deutsche mark-5 tokens), and setima (steamer-1 token). These types demonstrated German affluence. Education is symbolised by the types $\bar{a}$ 'oga (school/education) and tusi (book, letters).

\subsection{7) Natural Environment}

Comprising only 3\% (3 types) and 1\% (3 tokens) of total types and tokens for Sāvali 1906, the three types identified under the NE category were 'āeto (eagle -1 token), lava (volcanic lava1 token) and povi (cow-1 token). The use of lava was subsequent to the 1905 volcanic eruption in the Gaga'emauga district on the island of Savai'i. This incident resulted in many people of Gaga'emauga being forced to relocate and lead to the establishment of the villages of Le'auva'a and Salamumu on the island of 'Upolu.

The use of the type povi coincided with German administration's interests in cattle farming. However, German annexation of Sāmoa was highly motivated by the planting and agricultural interests of the plantation company Deutsche Handels and Plantagen Gesellschaft (formerly 
Godeffroy and Sohn). The absence of types referencing plantation developments during this time is surprising.

\subsection{8) Other}

The only type in the OTH category is faitau (read). Appearing five times, faitau was used to refer to the Samoan census of 1906, where it was collocated to read and count the number of births and deaths in Sāmoa at the time. But the census was used for more disturbing purposes such as the Germans' initiation of ethnic segregation where residents were categorised as either Europeans, mixed-Samoans (also known as resident aliens) or native Samoans. The latter were less privileged than the prior two (Hugh, 1978; Lang, 2002).

\subsection{9) Overview of Sāvali 1906 findings}

There are a total of 107 unique foreign types identified in Sāvali 1906. Combined, the foreign types in Sāvali 1906 consists of $5.5 \%$ of the total foreign types in the corpus.

In summary, NE and OTH categories were the least represented for both types and tokens. In contrast, SC and PN were well represented. These results may indicate an emphasis by the German administration on governance, nationalism and development.

\section{6) SULU 1906 FILES}

The high level distinction of categories for Sulu 1906 are organised in Table 9 below.

Table 9:

Categories/Types/Tokens: Sulu 1906

\begin{tabular}{|c|c|c|c|c|}
\hline \multicolumn{5}{|c|}{ Sulu 1906} \\
\hline Categories & Types & $\%$ & Tokens & $\%$ \\
\hline 1. Place Names & 84 & 19 & 281 & 10 \\
\hline 2. Proper Nouns & 107 & 24 & 791 & 28 \\
\hline 3. Religious Culture & 105 & 24 & 924 & 32 \\
\hline 4. Social Culture & 66 & 15 & 457 & 16 \\
\hline 5. Material World & 62 & 14 & 331 & 12 \\
\hline
\end{tabular}




\begin{tabular}{|c|c|c|c|c|}
\hline 6. Natural Environment & 18 & 4 & 40 & 1 \\
\hline 7. Other & 4 & 1 & 44 & 2 \\
\hline Total & 446 & $100 \%$ & 2868 & $100 \%$ \\
\hline
\end{tabular}

\subsection{1) Table 9 Analysis}

Apart from the 107 types categorised under PN, Table 9 shows an even distribution of types under PLN (84 types-19\%), RC (105 types-24\%), SC (66 types-15\%) and MW (62 types-14\%). The clustering of types around PNs and RC is not surprising given the impact Christianity has had on naming and religion in Sāmoa. Again, very few types and tokens are accounted under the NE and OTH categories. In regards to tokens, RC were used more frequently and accounting for $32 \%$ of all tokens compared to any other category.

\subsection{2) Place Names (PLN)}

With 84 types, PLN can be attributed to five geographical areas: (1) Europe; (2) Middle East; (3) Asia; (4) America and (5) the Pacific. The types attributed to these five geographical localities are divided into three sub-categories: (1) national, (2) city, and (3) ocean. The latter is the least frequent.

The majority of PLN were associated with Europe and the Middle East. These PLN were used as reference locations to Biblical narratives. Types such as Ierusalema (Jerusalem-10 tokens), 'Isaraelu (Israel-7 tokens), and Kalilaia (Galilee-6 tokens) were prominent. European countries included types such as 'Egelani (England - 5 tokens), Lonetona (London-3 tokens) and Sekotilani (Scotland-1 token) were used to make reference to England as the parent country of the LMS denomination.

Reference to Asian cities in the text, such as Amoi, Uagi-Pi, Hupē, Uei-Sene, Fukiena, Hunana and Hiao-Saga (all located in China with 1 token each) were primarily used to address Christianity to Samoans as a global religion. Interestingly, there is no reference to the Chinese indentured labourers working in Sāmoa at the time. The Japanese city of Manchuria (Manesuria) is mentioned once.

Other countries and cities, such as Filipaine (Philippines -2 tokens), 'Initia (India-10 tokens), Suiselani (Switzerland-4 tokens), 'Amerika (America-11 tokens), Unaite Setete 
(United States), Potilani (Portland), Sana Faraneseko (San Francisco-1 token), Sana Pitaporo (St. Petersburgh-1 token) and Veasinia (Virginia-1 token), were also used for similar purposes. Interestingly, no German place names were found.

Compared to the two types in Sāvali 1906, Pacific PLN (21 tokens) were well represented here by Fiti (Fiji), Kalaigolo (PNG), Kilipati (Kiribati), Niu Kaletōnia (New Caledonia), Lifu (Lifou Island), Niue (Niue), Niu Sila ${ }^{18}$ (New Zealand), Havai 'i (Hawaii) and Niu Kini (New Guinea). Ocean PLN included only two types: Sami Pātika (Baltic Sea-2 tokens) and Sami Uliuli (Black Sea-2 tokens).

Reference to the PNG related cities collocated with Samoan missionary activity in Sāmoa as opposed to any reference to the Melanesian indentured labourers, where the majority were from the Bismarck Archipelago in PNG. Solomon indentured labourers in Sāmoa also received no mention.

The foreign equivalents for the transliterated types Vatorata and Taisana are unknown.

\subsection{3) Proper Nouns (PN)}

The following sub-categories constitute the make-up of the PN category:

people, deity, texts (Bible and chapters), denomination (e.g. Wesleyan), days of the week, months of the year

As expected, people names dominate PNs (73 tokens). With the majority of names having Biblical origins, the only exception is Lao, a transliteration of the Indian name Lal. Interestingly, the first use of types for days of the week appear in this file. Also, the type Teviti (David) stands out. Today, David in Samoan is spelt Tāvita. It is possible that Tāvita is a result of orthography change over time. The lexical differences may be a result of denominational distinction, something common in religious names. These remain unknown. The most frequent PN, however, is not a person name, but Iesu (Jesus) with 194 tokens. This is followed by Atua (Christian God) with 163 tokens. In fact, the most frequently used person name is Neueli (Newell) with 27 tokens, which is collocated with the type Misi (Mister) ${ }^{19}$.

\footnotetext{
${ }^{18}$ Sometimes pronounced as $N i$ ' $u$ Sila

${ }^{19}$ Misi Neueli (Mister Newell) was a prominent missionary in Sāmoa during the time. It is important to note that in general, the term Misi can also mean "European Missionary."
} 
Aso $S \bar{a}$ (Sunday) is the most frequently used day of the week with 20 tokens. Aso $S \bar{a}$ is used in the text in phrases such as faitau $i$ le Aso Sā (read on Sunday) and $\bar{A}$ 'oga a Tama 'i Aso Sā (Bible study on Sundays) to remind readers of the sacredness and instructional (education) purposes of the day. Mati (March) and Me (May) are the two most frequently used months of the year with thirteen and nine tokens respectively.

\subsection{4) Religious Culture}

The RC category is mainly comprised of types associated with social status in the Church. One of these status is faife 'au (pastor) with 61 tokens, the most frequently used. The type faife 'au is used consistently and frequently through the files examined. The introduction of Christianity resulted in the creation of new social positions or offices such as faife 'au (pastor), failautusi (church secretary) and $t i$ 'ăkono (deacon). The high frequency of CCCS related types has overshadowed the absence of types potentially associated with other denominations.

Types to do with communal worship are very prominent. Tatalo (prayer-75 tokens), lotu (religious service-worship-58 tokens), and läuga (sermon-43 tokens), for instance, are widely used. These types were collocated to inform readers of the importance of communal and individual spirituality.

A movement of newly introduced groups targeting specific social classes, such as Elders and youth, were also frequently used. 'Au Taumafai, a group created for youth worship, had 83 tokens. Sosaiete, a group for pastors and deacons, was used 27 times. Other groups such as ' $A u$ Toea 'ina (Elders Committee), 'Au Mātutua (Church Elders), 'Au Pa ia (Congregants) and 'Au Manumalo (retired pastors) were low in frequency. The latter three are now defunct positions in the CCCS denomination structure.

An important observation in $\mathrm{RC}$ is the emergence of newly created phrases of loan translations and semantic loan types. Loan translations such as 'au'auna a le Atua (servant of God-1 token) and taulaga tagata (family offering-1 token), are all variations of faife 'au. The semantic loan failāuga (2 tokens) is also a variant of faife 'au. Similarly, 'Au Fa'atonu (1 token) is a variant of 'Au Toeā'ina. More semantic loans emerge when examining types such as Matai, Alo, and Tamā, which all refer to the Christian deity. Similarly, the type Silisili 'Ese, a loan translation, is also a variant of the above. 
From the above, the significant social and religious changes in Sāmoa in the period 1906 are reflected in the types used. The emergence of phrasal types in the vernacular, such as ' $\mathrm{Au} \mathrm{Pa}$ ' $\mathrm{ia}$ and taulaga tagata, are signs of the gagana adapting and configuring ways to accommodate the vast introduction of foreign ideas and concepts.

\subsection{5) Social Culture}

More phrasal types appear in the SC category where the majority are directly linked to governance. All newly created types such as ali ‘i sili (president-3 tokens), ali ‘i tōfia (government official-2 tokens), ametimane (German official-1 token), failautusi (government secretary-9 tokens) ${ }^{20}$, komisi (commission-3 tokens), kōvana (governor-2 tokens), faipule (village-district mayor-2 tokens), kaisa (kaiser-5 tokens) and kaisalika (imperial government-2 tokens), for instance, are government related.

Other secular roles such as föma ' $i$ (doctor -8 tokens), tausi ma ' $i$ (nurse -1 token), fa 'amasino (court judge -1 token), leoleo (police officer-2 tokens), ali 'i lomitusi (publisher-1 token) and fa $^{\text {'atonu }}$ (director -1 token), for instance, have contributed to the expansion of the gagana. The appearance of the type fa 'amasino is reflective of the establishment of the Land and Titles Commission (LTC) lead by a German Supreme Judge (fa'amasino sili) in 1903.

Faiā' $\operatorname{og} a$ (teacher-5 tokens) in Sulu 1906 is a position more aligned to the church, rather than government as government schools were only introduced in 1907. Hempenstall (2016, p. 52) notes that there were 299 mission schools of various denominations that were in operation in Sāmoa in 1906 with an estimated 10,000 pupils nationwide.

Types for economic and educational progress such as fa' atau 'oloa (shop keeper-2 tokens), totogi (wages - 37 tokens), tagata faigaluega (employee-1 token), vaiaso (week-1 token), tausaga (year-85 tokens), vasega (school classroom-2 tokens), su'ega (school exams-5 tokens) and māsina (month-42 tokens), indicate a nation negotiating with and immersing itself in foreign systems.

\subsection{6) Material World}

${ }^{20}$ Also see failautusi for Church p.7 
In 1906 Sāmoa, the types in the MW category reflect a nation modified and influenced by foreign merchandise.

Samoans were already exposed to many forms of merchandise being tusi pese (hymn book1 token), Tusi 'o le Ola (Bible-1 token), là'au lomitusi (type writer-1 token) and pepa (paper -5 tokens). The rise in government schools and departments, however, initiated the introduction of more text forms such as tusi numera (maths book), tusi 'aisi (letter for finance) and tusi talosaga (letter of appeal). The heightened presence of foreigners and systems resulted in a proliferation of new merchandise and the associated vocabularies.

But perhaps the most expensive material form are buildings. Falema ' $i$ (hospital -1 token), fale lomi tusi (print shop-13 tokens), fale fa 'atau vaila' 'au (chemist-1 token), fale 'oloa (outlet1 token), fale papālagi (European styled house-1 token), fale puipui (prison-2 tokens), fale teu tupe (bank-1 token), fale vali (paint outlet-1 token) and $\bar{a}$ 'oga (school premises-23 tokens), illustrate the developing infrastructure.

To use local services, some form of affluence was required. In this sense, currency is another prominent MW. This is reflected in the types tupe (money-22 tokens), sisipeni (sixpence-2 tokens), sêleni (cent-4 tokens), talā (dollar-2 tokens), teiō (Deutcshe-1 token), fenika (fenig-3 tokens), maka (Deutsch mark—1 token), 'ārio (silver-1 token), miliona (million4 tokens) and 'auro (gold-1 token).

Evidently, MW in 1906 Sāmoa was manifested by newly introduced items which not only modified and influenced social relationships, but also changed the landscape of Samoan material wealth.

\subsection{7) Natural Environment}

Foreign types in NE are linked to animals and natural surroundings. The most frequently used type is lava (volcanic lava-13 tokens). This frequency is based on the volcanic eruption on the island of Savai'i in 1905, which was still news in 1906.

Four animals appear in the file (1) māmoe (sheep-3 tokens); luko (wolf-3 tokens); (2) solofanua (horse - 2 tokens), and povi (cow-1 token). Interestingly, only the latter two were found in Sāmoa at the time. Other types that appear are 'ekueta (equator-1 token), māsima (salt—4 tokens), suāu 'u (oil—1 token) and foseferi (phosphate-1 token). 
All animal related types have a connection to a Biblical narrative (e.g. kāmela, luko and māmoe) or developments as a result of foreign influence in Sāmoa (e.g. ma 'umaga (plantation)), which was initiated by the Germans as a way for Samoans to earn money to pay taxes (Meleiseā \& Schoeffel 2017, p. 156).

\subsection{8) Other}

Four types were identified under OTH category. All verbs, the most frequently used type is faitau (to read-41 tokens). Collocations of faitau point to a national fixation with not only reading, but the perusal and study of biblical literature. The tone of collocations was instructional with most passages, such as 'ia faitauina le Tusi Pa'ia (must read the Bible) and faitau ma le mäfaufau (to read with purpose), pressing the need to sustain spiritual and physical connection to the Bible.

The remaining types are fa 'atau (purchase-3 tokens), tusitusi (write-1 token) and sota (to sort-1 type).

\subsection{9) Overview of Sulu 1906 findings}

46\% (446 types) of Sulu types were sourced from Sulu 1906 foreign types. Category findings address forms of governance change which are evident in the creation of new government roles. The use of PLN to depict global religion, deity names in PNs, the ascendency of status based types in SC, and the high use of building related types depict Sāmoa as a place of immense social change during this time.

\section{7) SĀVALI 1944 FILES:}

Table 10 presents a categorical break-down of foreign types and tokens for the file.

Table 10:

Categories/Types/Tokens - Sāvali 1944

\section{Sāvali 1944}

\begin{tabular}{|l|c|c|c|c|}
\hline Categories & Types & $\%$ & Tokens & $\%$ \\
\hline
\end{tabular}




\begin{tabular}{|c|c|c|c|c|}
\hline 1. Place Names & 6 & 6 & 18 & 3 \\
\hline 2. Proper Nouns & 18 & 19 & 140 & 23 \\
\hline 3. Religious Culture & 18 & 19 & 112 & 19 \\
\hline 4. Social Culture & 42 & 33 & 137 & 23 \\
\hline 5. Material World & 21 & 22 & 183 & 31 \\
\hline 6. Natural Environment & 1 & 1 & 1 & 1 \\
\hline 7. Other & 0 & 0 & 0 & 0 \\
\hline Total & $\mathbf{9 6}$ & $\mathbf{1 0 0}$ & $\mathbf{5 9 1}$ & $\mathbf{1 0 0}$ \\
\hline
\end{tabular}

\subsection{1) Table 10 Analysis}

A total of 96 foreign words were identified in Sāvali 1944. A significant observation is drawn when comparing Sāvali 1944 (Table 10) with Sāvali 1906 categories in Table 8. While the overall distribution of types is similar, there is a significant increase in foreign types in SC with 42 foreign types in 1944 compared to 29 in 1906. The increase is correlated to the introduction of new social roles, particuarly national, regional and village committees such as komiti a Tama 'ita ‘ (Women’s committee), Komiti Ali ‘i Tōfia (Government Officials Committee) and Komisi (Commission). Foreign types in the MW, RC and PN cateogries have also increased with 21, 18 and 18 foreign types added, respectively. The reason for the increase in RC tokens was due to the Sāvali's inclusion of funeral notices. The increase in MW tokens is linked to the increase in the RC category. The type fales $\bar{a}$ (church building-36 tokens) and malumalu (church building-17 tokens), for instance, were consistently used in funeral notices. Additionally, the type tusi (write), which received the most tokens of 107, contributed to the increase in MW tokens due to another newspaper development-the inclusion of church fundraising notices. The inclusion of church fundraising notices refers to the strengthening colloboration between government and church.

In terms of new foreign types, 39 were identified in Sāvali 1944. It is in the PN and SC categories where there are notable numbers of new foreign types. No new types were found for both the NE and OTH categories. Important to note, Sāvali 1944 contributed the least number of new types out of all the issues examined. A more in-depth break-down of foreign types per category is provided in the succeeding sections. 


\subsection{2) Place Names}

Niu Sila (New Zealand-9 tokens) is the most frequently used type, followed by 'Amerika (America-3 tokens) and Maketōnia (Macedonia-3 tokens). Niu Sila is used in the file to cite diplomatic relations with Sāmoa. By 1944, relations between Sāmoa and New Zealand remained tense as Samoans, through the Mau, Samoa's peaceful opposition movement towards the New Zealand administration's paternalistic policies, strived for self-governance. Staying with the diplomatic relation discussion, 'Amerika is used to refer to economic prosperity in phrases such as Tupe 'Amerika (American currency). Also of diplomatic significance is the use of Peretānia (Britain-2 tokens) which was collocated to reference the Tupu Tama'ita' $i$ ' $o$ Peretānia (Queen of Britain). This is not surprising considering New Zealand's dominion status under Britain at the time. In addition, however, is the likelihood that these place names correlate to New Zealand, British and American marine presence in Sāmoa. Japan's attack on Pearl Harbour in 1941 brought World War II close to Sāmoa. As a result, fortifications were being constructed in preparation for any attacks on Sāmoa by the Japanese.

The only type related to the Pacific is Toga (Tonga) which is collocated in the phrase Tupu Tama 'ita'i 'o Toga (Queen of Tonga).

The sole new PLN found in Sāvali 1944 that did not appear in earlier issues and the earlier indicator year 1906 is the type Maketōnia (Macedonia) with 3 tokens. Interestingly, Maketōnia here is used in a Biblical context.

\subsection{3) Proper Nouns}

For a government newspaper, the most frequently used type was not a secular PN, but rather types associated with Christianity.

- $\quad$ L.M.S. (London Missionary Society) 38 tokens

- Atua (Christian God) 17 tokens

- Katoliko (Catholic) 11 tokens

- Metotisi (Methodist) 4 tokens

Other types such as Iesu (Jesus-2 tokens), Ieova (Jehovah-1 token), Keriso (Christ-2 tokens) and Kirisimasi (Christmas - 1 token) are also used. Again, the evolution of Sāvali to include obituaries and fundraising notices has contributed to the high type numbers. Looking 
at it another way, it draws attention to an existing correlation between governance and religion in Sāmoa.

The sub-category with the highest frequency was months of the year ( 82 tokens). Types to do with days of the week had a combined frequency total of 12 tokens. Overall, PNs in Sāvali 1944 are consistent with the analysis of PNs in Sāvali 1906. That is, despite people names and months of the year having more types, deity names are used more frequently.

Compared to the PN category in Sāvali 1906, fourteen new PNs were identified in Sāvali 1944. These are as follows:

- 'Elisapeta

- 'Epati

- Katoliko

- Koluse Mumu

- Komiti a Tama 'ita ' $i$

- Kōvana Sili

- $L M S$

- Metotisi

- Nelesoni

- Peteli

- Tama ita i i $S \bar{a}$

- Tapa'aulēfano

- Тири

- Ulu
Elizabeth

Pat

Catholic

Red Cross

Women's Committee

Governor

London Missionary Society

Methodist

Nelson

Peter

- $\quad$ Catholic nun

Christian deity

Christian deity

Head of Department (HOD)

People name PNs were low and are represented by the types 'Elisapeta (Elizabeth-4 tokens), 'Épati (Pat-1 token) and Pèteli (Peter-1 token). There appeared a number of English PNs in this file. For example, Nelson (referring to Samoan and German resident Olaf Nelson) and Mr. Fraser (a missionary). These English names were not included in the corpus. But when names took Samoan orthography, such as Nelesoni (Nelson), these were inserted into the corpus. Nelesoni (Nelson), as he was known, was one of the main leaders of the Samoan Mau and lead the presentation of a Samoan petition to the League of Nations opposing New Zealand's administering of Sāmoa (O'Brien, 2007). 
An interesting type in the above list is the type Tapa 'auleffano which is used to mean Christian deity. If there is a type which has accumulated many lexical expansions it is the Christian deity. Other lexical expansions of this type include Atua (God), Tamā (Father), Tamā aoao (Godly Father), Тири (King), Tupu Moni (The true King), Тири 'o Tupu (King of Kings) and Tamā 'o 'i le lagi (Father in Heaven). In traditional times, the term Tapa 'auléfano was used to refer to possibly Mālietoa, the leader of Sāmoa who accepted Christianity in 1830. Interestingly, however, the type has lost relevance as a reference for both Samoa's Christian deity and indigenous chiefs, such as Mālietoa. How it has lost relevance remains unknown, but it does show the tendency for Samoans to assign their most prestigious words to a higher power.

In terms of government, it is represented by the types Koluse Mūmū, Komiti a Tama ita 'i, Kōvana Sili and Ulu. These types indicate that by 1944, new social roles, at least in government, indicated the rise in influence of the central government sector particularly in the realms of health, local governance and education.

The Catholic related types Tama 'ita ' $i$ Sā and Katoliko deserve some attention. It is interesting to note that while the English word nun is integrated into Samoan using words found in the Samoan vocabulary, i.e. tama ita ' $i$ (unititled daughter) and $s \bar{a}$ (sacred), the name of the Church or religion is integrated phonologically. In fact, the names of all three mainstream denominations in Sāmoa of Lotu Ta 'itì ${ }^{21}$ (LMS), Metotisi (Methodist) and Katoliko (Catholic) are all loanwords.

\subsection{4) Religious Culture}

The RC category includes types connected to vocation. To make sense of the many layers of types found, four sub-categories were identified:

Church structure:

$\begin{array}{lll}\text { Tapa'aulefano } & \text { (Chrisitan God) } & 1 \text { token } \\ \text { Fa'aola } & \text { (Jesus) } & 1 \text { token } \\ \text { 'ekelesia }^{22} & \text { (congregation) } & 7 \text { tokens }\end{array}$

\footnotetext{
${ }^{21}$ The term Ta iti is a loanword for the word Tahiti. It is used to refer to the Congregational denomination to symbolise the arrival of the LMS missionaries in 1830 from Tahiti.

22 'Ekelesia here is a variant spelling of 'ekālesia
} 


$\begin{array}{lll}\text { 'aulotu } & \text { (congregation) } & 2 \text { tokens } \\ \text { matāgaluega } & \text { (synod) } & 2 \text { tokens }\end{array}$

Church status:

$\begin{array}{lll}\text { faife 'au Sāmoa } & \text { (Samoan pastor) } & 5 \text { tokens } \\ \text { feagaiga } & \text { (pastor) } & 4 \text { tokens } \\ \text { 'aposetolo } & \text { (apostle) } & 2 \text { tokens } \\ \text { faife' 'au } & \text { (pastor) } & 1 \text { token } \\ \text { tama'ita'i } \overline{\text { sa }} & \text { (nun) } & 1 \text { token }\end{array}$

Church practice:

$\begin{array}{lll}\text { tusigāigoa } & \text { (donation) } & 89 \text { tokens } \\ \text { galuega } & \text { (vocation) } & 14 \text { tokens } \\ \text { lotu } & \text { (service) } & 10 \text { tokens } \\ \text { sauniga } & \text { (service) } & 7 \text { tokens } \\ \text { 'aufaipese } & \text { (choir) } & 2 \text { tokens } \\ \text { taulaga } & \text { (donation) } & 1 \text { token } \\ \text { tapuā'iga } & \text { (service) } & 1 \text { token }\end{array}$

Spirituality:

$\begin{array}{lll}\text { lagi } & \text { (heaven) } & 17 \text { tokens } \\ \text { fa'atuatua } & \text { (faith) } & 1 \text { token }\end{array}$

Because the Samoan church, namely the CCCS, is self-governed, it requires two things from people to continue its growth. These are: (1) time and (2) money. Time is depicted in the types galuega, lotu, sauniga, 'aufaipese and tapuā'iga, where considerable involvement in church services, meetings, development, maintenance, travel, religious education, youth groups and cultural practices is required. Monetary donations, such as tusigäigoa and taulaga, are two of many monetary obligations in church. Both time and monetary donations have been heavily criticised by Samoans and non-Samoans alike.

The extent of donations needs to be adapted in light of people's changing socio-economics. But change, however, needs to be Church led. Church here refers to the mother church, pastors, congregations and elders. The Church, for example, needs to find ways to subsidise their 
pastors' incomes. Pastor's need to enforce at the congregational level alternatives to lessen monetary burdens on families. But socio-economic change, however, is a Western influence.

The call for donations links to changes in society. As the life source of capitalism, the introduction of Western currency supplemented indigenous forms of wealth. Giving is a precontact practice, where cultural valuables such as 'ie tōga (fine mats) and siapo (tapa) and food were used. The purpose of gifting in Samoan culture was/is to create new and maintain kinship relations. In pre-contact Sāmoa, the quality and quantity of fine mats was what measured the wealth of families, and subsequently, the success of these exchanges. These pre-contact measures have been maintained by many Samoans in their gifting practices to the church, a foreign institution. The introduction of capitalism, therefore, has complicated what was once a practice sourced by the natural environment ('ie toga and siapo are made from Samoan flax). The fusion, and the relative complexities and complications, between indigenous and Western ideologies, is highlighted in these examples.

Summations can be made from an analysis of the collocations for the above types:

- The most frequent type is tusigäigoa. A practice where members of a congregation or village make monetary contributions for a new church building, was used 89 times.

- Because of the church's independence, the L.M.S (or LMS) acronym is no longer used today.

- The type Tapa'auléfano is also outdated.

- An interesting observation made is the use the type 'ekelesia with the Catholic denomination and 'aulotu with the Congregational (LMS) denomination. 'Ekelesia, a variation of 'Ekālesia, is no longer used.

- The type aposetolo is only used when referring to an apostle (or disciple) while the terms faife ' $a u$ and feagaiga are used to refer to a Samoan pastor.

Like the PLN category in Sāvali 1944, only one new foreign type was found for RC. The type is the collocation faife 'au Sämoa (5 tokens), which literally translates as Samoan pastor.

Sometimes abbreviated as FS, the development of the type faife 'au Sämoa came about for a number of reasons mainly to do with distinguishing from other clergy. The first reason was to distinguish between faife 'au who were educated in Sāmoa and at MTC, which is the Congregational denomination in Samoa's theological insitution, and those who were not. The 
second and final reason was to distinguish Samoan Congregational pastors from clergy from other Pacific nations who were still in the Samoan field.

The type faife 'au Sämoa is still used today to distinguish MTC graduates from faife 'au who graduated from overseas theological institutions. The development of the type faife 'au Sämoa, from say the type faife 'au, which was coined much earlier, signifies the need to adapt and construct new words for changing social forces.

\subsection{5) Social Culture}

The top five most frequently used types in this category are:

$\begin{array}{lll}\text { 1. tusigāigoa } & \text { (church fundraising) } & 89 \text { tokens } \\ \text { 2. faipule } & \text { (district mayor) } & 50 \text { tokens } \\ \text { 3. mālo } & \text { (government) } & 38 \text { tokens } \\ \text { 4. lömiga } & \text { (publication) } & 17 \text { tokens } \\ \text { 5. ' ири } & \text { (print) } & 13 \text { tokens }\end{array}$

All four types are used to allude to the governance and communicative roles of the administration. As a result, thirty-seven percent (16) of types in this category are linked with government positions. The most frequently used type is faipule (district mayor-50 tokens). Kōvana (Governor) was next with a frequency of 12 . Note, the types kōvana and kōvana sili are distinct words referring to governor and president, respectively. Other government positions include:

- Pālemia (Prime Minister) 6 tokens

- Fono (government meeting) 5 tokens

- Kōvana Sili (president) 3 tokens

- Minisitā (Cabinet Minister) 1 token

With fewer tokens are the types fono (government meetings - 5 tokens), komiti (committee5 tokens), fautua (adviser-3 tokens), komiti a tama ita i (women's committee-3 tokens), komisi (commission - 2 tokens) and komesina (commissioner-1 token). During New Zealand occupation, like the times of German occupation of Sāmoa, many government fono between administration and native groups were being held either as consultation with foreign authority 
or in opposition of it. Many komiti were also established as either for or against New Zealand administration. Other komiti, such as the Komiti a Tama ita ' $i$ was established as part of the NZA's prioritising of village development and health sector growth (the type koluse mūmu (Red Cross - 1 token) is collocated). Komisi, such as the Royal Commission, was established to look into Samoan complaints towards the administration (Meleiseā et al. 2017, p. 135). When the Germans were deported, the office of Ali ' $i$ Sili was changed by the New Zealand administration to the office of Fautua, which became the highest post in the native administration. Three fautua were appointed; Malietoa Tanumafili I, Tupua Tamasese Lealofi III, and Tuimaleali'ifano Si‘u.

Educational positions were also represented with types such as sui pule (deputy principal-2 tokens), pule à 'oga (school principal-1 token) and vasega (class-1 token). The type uaealesi (wireless telegram -1 token) appears for the first time.

For the SC category, 13 new foreign types were identified. These are:

- $a . m o$.

- fai-tūlāfono -

- fautua

- fono

- komesina

- minisitā

- pālemia

- pule à'oga

- pulinisese

- sui pule

- tausala

- uaealesi

- $v \bar{a} ' a i f e t \bar{u}$ a.m.

law/policy maker

advisor

government meeting

commissioner

government minister

prime minister

school principal

princess

deputy principal

church fundraiser

wireless

observatory

A unique feature in the Sāvali 1944 text is the appearance and inclusion of church fundraising notices called tusigāigoa, which literally translates as tusi (to write) igoa (name). Similar to tusigāigoa, a tausala is an event where members of a congregation or village make monetary contributions to a church cause. Both tusigäigoa and tausala notices were projected nationally, with particular emphasis for Samoans who had connections to the village where the tusigaigoa 
and tausala were to be held. Out of all the new types identified, tausala was the most frequently used type with 89 tokens.

National government development is highlighted in the types fai-tulafono ( 2 tokens), fautua (3 tokens), fono (5 tokens), komesina (1 token), minisitā (1 token), pālemia (6 tokens), pule à 'oga (1 token), sui pule (3 tokens), uaealesi ( 1 token) and $v \bar{a}$ 'aifet $\bar{u}$ ( 1 token). Note that the type pālemia is used to refer to the prime minister of New Zealand, as opposed to a Samoan prime minister, which post was not created until after 1962.

The type fautua is used to refer to Samoans who were elected to the native administration panel. These roles, however, were largely reserved for prominent high chiefs of the country, such as Mālietoa Tanumāfili I, Tupua Tamasese Lealofi III and Tuimaleali 'ifano Si‘u. During the New Zealand occupation, as under the German occupation of Sāmoa, many government fono between administration and native groups were being held either as consultation with foreign authority or in opposition of it.

Educational positions were also represented with types such as sui pule (deputy principal—2 tokens), and pule à'oga (school principal-1 token).

\subsection{6) Material World}

Building and currency types dominate MW category. Under buildings types include:
- falesā (church) 36 tokens
- fata (church) 2 tokens
- malumalu (church) 17 tokens
- falemeli (post shop) 1 token
- 'ófisa (offices) 6 tokens
- $\bar{a} \log \quad$ (school) 4 tokens
- 'ófisa $v \bar{a}$ 'aifetū (observatory)1 token

From the above, $90 \%$ of tokens are attributed to a church building. The remaining types, such as $\bar{a}$ 'oga and falemeli, are collocated to refer mainly to overseas education (e.g. Niu Sila mō $a^{\prime}$ oa'oga-New Zealand for education) and overseas communication. 'Öfisa, on the other hand, is used to refer to local government offices (e.g. 'Ōfisa 'o le Mālō-government office and 'ōfisa vā'aifetū).

Though low in token frequency, currency related types are quite prominent, also: 
- tupe (money) 33 tokens

- sēleni (shilling) 11 tokens

- $\operatorname{talā~(dollar)~} 4$ tokens

- sene (cent)
- siliva (coins)

2 tokens

- taime (dime)

2 tokens

- ‘ārio (silver)

1 token

Tupe is a semantic loan. In pre-European times, tupe was the term given to a flat coconut shelled disc used in the chiefly game taulafoga. Every other currency related term above was introduced after foreign arrival. Taime is obsolete today, even in Tutuila (American Sāmoa). Only sêleni, which is only used in Tutuila to refer to the quarter coin, and sene, siliva and talä, which are more commonly used in Independent Sāmoa, are still used today. The withdrawal of the Germans from Sāmoa resulted in the disuse of German currency, such as maka, which was used in 1906. One of the interesting developments that took place during New Zealand administration of Sāmoa was the use of taxation to bankrupt Samoans and in effect their efforts to fund material and travel expenses for any opposition plans (Meleiseā, Meleiseā et al. 2017, p. 138).

With 107 tokens, the most frequently used type is tusi (book/letter). Again, the use of tusi in the file is directly connected to church related activities such as tusigāigoa. In addition, tusi is also used to refer to chapters in the Bible (e.g. Tusi a Hosea-Book of Hosea) and written letters (e.g. tusia e 'Épati-written by Pat).

The first form of land transport also emerged in this file with the type ta 'avaleafi (automobile). Other new terms that emerged are simā (concrete-1 token), niusipepa (newspaper-16 tokens), koluse (wooden cross-1 token) and ma'a fa'amanatu (head stone-1 token). The type koluse is commonly used by the Catholic denomination. The CCCS denomination, in contrast, prefer to use sātauro. These terms of use are prevalent in services of these respective denominations.

Only eight new foreign types were found under MW category:

- fata

- koluse

- 'ofisa vā'aifetū

- sene

- siliva hospital stretcher

cross

observatory office

cent

silver (but referring to coins) 
- $\operatorname{sim} \bar{a} \quad-\quad$ cement

- ta'avaleafi - automobile

- taime - dime

These new types have low frequencies, with the highest token of 2 attributed to the types fata, koluse, sene and siliva.

The words fata and ta 'avaleafi are interesting collocations. Fata, an indigenous word meaning a shelf, has had a semantic expansion. Ta 'avaleafi, on the other hand, is comprised of the two existing words of ta'avale, which means car and is a truncation of the verb ta'avalevale, and afi, which has had a new meaning added to it to mean engine on top of its existing meaning of fire.

Simā, is a loanword from English. 'Ofisa $v \bar{a}$ 'aifetu is another lexical expansion of the type $v \bar{a}$ 'aifetu (see Section 5.7.5). The addition of the type 'ofisa, also a foreign word, makes it an office with specific and government responsibilities.

\subsection{7) Natural Environment}

The natural environment is solely represented by the type solofanua (horse- 1 token). The origins of the type solofanua is argued to be from either Tahiti or Tonga.

\subsection{8) Other}

No new foreign types appeared in Sāvali 1944 for the OTH category.

\subsection{9) Overview of Sāvali 1944 findings}

The foreign types in Sāvali 1944 direct our attention to a society that existed within intense winds of new social roles, taxation, fundraising initiatives at the church level and the continued development of its local infrastructures. These areas of Samoans' social lives would determine her readiness and commitment for self-governance. Since 1906, a total of 39 new foreign words emerged in 1944. 


\section{8) SULU 1944 FILES}

Table 11 presents a categorical break-down of foreign types and tokens for the file.

Table 11:

Categories/Types/Tokens: Sulu 1944

\begin{tabular}{|c|c|c|c|c|}
\hline \multicolumn{5}{|c|}{ Sulu 1944} \\
\hline Categories & Types & $\%$ & Tokens & $\%$ \\
\hline 1. Place Names & 21 & 16 & 41 & 7 \\
\hline 2. Proper Nouns & 43 & 33 & 239 & 44 \\
\hline 3. Religious Culture & 27 & 21 & 174 & 32 \\
\hline 4. Social Culture & 25 & 19 & 61 & 11 \\
\hline 5. Material World & 12 & 9 & 24 & 5 \\
\hline 6. Natural Environment & 2 & 2 & 8 & 1 \\
\hline 7. Other & 0 & 0 & 0 & 0 \\
\hline Total & 130 & 100 & 544 & 100 \\
\hline
\end{tabular}

\subsection{1) Table 11 Analysis}

Consistent with previous findings, the NE and OTH categories are again low and not represented in foreign types. The majority of foreign types again fall under the RC, SC, PN and MW categories. A more detailed examination of foreign types per category is provided in Sections 5.8.2-5.8.8.

\subsection{2) Place Names}

Place names in Sulu 1944 are attributed to the following geographical areas:

- Pacific 3 types

- Middle East 4 types
(21 tokens)

(10 tokens)
- Europe 2 types

- Americas 1 type
(5 tokens)

(2 tokens)

Pacific PLNs were generally used in collocations about the establishment and growth of Christianity in the region. The types Pа̄pua and Niu Kini are used separately in some cases. This is direct reference to Päpua being a territory of Australia and Niu Kini a territory of Britain 
before it became an independent nation, thus now called Pāpua Niu Kini. The other Pacific PLN is Atu Polenisia (Polynesia). Middle East types were collocated with Biblical narratives. Israeli cities, such as Kinereta (Kinnereth), Tiperia (Tiberias) and Ierusalema (Jerusalem) are popular types. Europe PLNs, particularly Peretānia (British), were used to reference British missionaries in Sāmoa. 'Amerika (America), the sole type in the Americas sub-category, was used to discuss a Unitarian conference held in America.

With a very low frequency ratio, the top two most frequently used type in PLN category are as follows:
- Ра̄pua Niu Kini
(Papua New Guinea)
9 tokens
- Peretānia
(Britain)
4 tokens

Of the 10 foreign types, a total of 5 new foreign types were found for this category. These are:

- Atu Polenisia - Polynesia

- Kinereta - Kinseret

- Rotuma - Rotuman

- Samāria $\quad$ - $\quad$ Samaria (Israel)

- Suisilani - $\quad$ Switzerland

Apart from the type Atu Polenisia, the types Kinereta, Rotuma, Samāria and Suisilani are all loanwords. Atu Polenisia is comprised of an indigenous word (Atu-atoll) and the loanword Polenisia (Polynesia).

There are a couple of interesting types. Firstly, is the type To'elau where the letter $k$ is removed from Tokelau, keeping in mind that the letter $k$ is one of three letters introduced by the missionaries to accommodate foreign words (see section 2.6.1 of Chapter Two). The word To'elau is a type of wind named after the northerly winds from Tokelau. This explains why the letter $\mathrm{k}$ was not added to accommodate a foreign word. Also of interest is the retention of the letter $v$ in the type Suva. This seems to be an exemption to the rule that all foregin types integrated into the gagana take Samoan orthography.

\subsection{3) Proper Nouns}


Proper nouns constitute 33\% (43) of types and 44\% (239) of tokens for Sulu 1944. The majority of PNs can be sub-categorised into the following areas. The four most frequently used types are:

$\begin{array}{cclll}- \text { deity names } & - & \text { Atua } & \text { (God) } & 84 \text { tokens } \\ & - & \text { Iesu } & \text { (Jesus) } & 46 \text { tokens } \\ & - & \text { Keriso } & \text { (Christ) } & 19 \text { tokens } \\ & - & \text { Ali } i & \text { (God) } & 8 \text { tokens }\end{array}$

The remaining types are Tamā (Father -5 tokens), Tири (King referring to God -4 tokens), Atali ' $i$ (Jesus - 1 token) and Alo (Jesus -1 token).

- people names

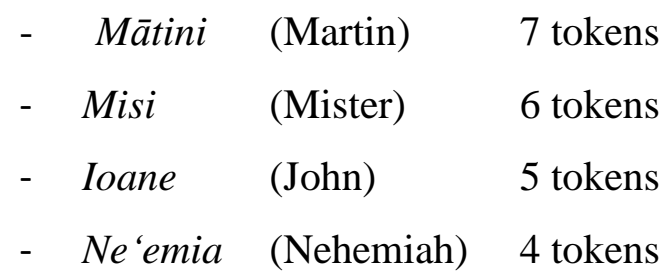

With low occurrence frequencies, other people names include Paulo (Paul), Saulo (Saul), Setefano (Stephen), Solomona (Solomon), Pēteru (Peter), Nisapeti (Nisbett), Neueli (Newell), Mariota (Marion), Māreko (Mark), Tāvita (David), Tana (Tanner), Kaino (Canan), 'Ēlia (Elijah), Hamanu (Hanun), Hanani (Hananel), 'Elise (Alice) and Timoteo (Timothy). The foreign equivalence for names such as Suitama and Teleso are not known.

Another sub-category that emerged was ethnicity and leisure. Ethnicity related types include Papālagi (European-1 token), Sāmaria (Samaritan-2 tokens) and Sā Iutā (Jew-1 token). Leisure is represented by kapeteni (captain - 3 tokens), which was used to refer to the captain of a Samoan cricket team.

- months and days - Tēsema (December) 1 token - Aperila (April) 1 token

Only two types for months and days were used. Intriguing, however, are references of supposed pre-Western terms for December-Kiselu, and April—Nisani. As possible alternatives, both terms are not recorded in Samoan dictionaries or ethnographies. The terms are demonstrated in the following collocations: 


\section{“...māsina lea o Tesema (Kiselu).” \\ “...tatalo iā Aperila (Nisani).”}

Other types in the PN category are categorised under Bible Chapters (Ioane and Evagelia). From the above findings, the majority of PNs have Biblical origins and have all taken Samoan orthographic form.

Of the 17 foreign types, 12 new types emerged. All people names, these are Paulo (Paul), Saulo (Saul), Setefano (Stephen), Solomona (Solomon), Nisapeti (Nisbett), Neueli (Newell), Mariota (Marion), Māreko (Mark), Tana (Tanner), Kaino (Canan), Hāmanu (Hanun), and Timoteo (Timothy).

\subsection{4) Religious Culture}

Constituting 29\% (27) and 24\% (174) of types and tokens respectively, there are 27 foreign types integrated into the gagana that fall under the RC category.

Like Sulu 1906, types associated with Church status and worship are notable here. One of the main developments is the increase of types identified under church sacraments. These include papatiso(ga) (baptism-5 tokens), fa 'amanatuga (eucharist-12 tokens) and talisuaga (also eucharist-1 token).

The most frequently used words in the RC category for Sulu 1944 are:

$\begin{array}{llllll}\text { - agasala } & \text { (sin) } & 37 \text { tokens } & \text { - mālamalama (Christian) } & 23 \text { tokens } \\ \text { - lagi } & \text { (heaven) } & 34 \text { tokens } & \text { - Kerisiano } & \text { (Christian) } & 13 \text { tokens } \\ \text { - 'ekalesia } & \text { (congregation) } 30 \text { tokens } & \text { - misionare } & \text { (missionary) } 12 \text { tokens } \\ \text { - Agaga Pa } \text { ia } \text { (Holy Spirit) } 23 \text { tokens } & \text { - pouliuli } & \text { (heathen) } & 12 \text { tokens } \\ \text { - fa'atuatua } \text { (faith) } & 23 \text { tokens } & - \text { mägalo } & \text { (forgive) } & 12 \text { tokens }\end{array}$

Here, types aligned with Samoans' sense of spiritual and physical wellbeing are striking. For instance, Samoans' spiritual and physical wellbeing are manifested in types such as fa 'atuatua (Christian faith), Agaga Pa ia (Holy Spirit), fili (satan), fa'apaupau (heathen), mālamalama (to become a Christian), pouliuli (non-Christian), tatalo (prayer) and taulaga (monetary and time offerings). 
Of the 27 foreign types, only 8 new types were found. These are as follows:

- 'au faigaluega

- 'au tala'i

- matā'upu silisili

- talisuaga

- olafou

- pouliuli

- 'Atimarala

- papatisoga clergy

clergy

theological theory

eucharist

new life

heathen

adjective used to

describe Jesus

baptism
2 tokens

1 token

2 tokens

1 token

3 tokens

12 tokens

8 tokens

5 tokens

Like Sulu 1906, types associated with Church status and worship are notable here. The types 'au faigaluega and 'au tala' $i$ are lexical expansions for the word clergy. The types indicate a group of clergy. While I am discussing lexical expansion, the type suafa is a lexical expansion for the Christian deity. If it were capitalised it would have been categorised under PNs. It is another addition to the already extensive list as addressed in Section 5.7.2.

An interesting type that emerges here is Atimarala (8 tokens). 'Atimarala is used as an adjective and noun to describe Jesus. For instance, 'O Keriso lo tātou 'Atimarala (Christ is our Atimarala), 'Atimarala Pa'ia (Holy Atimarala) and 'Atimarala Fa'alelagi (Heavenly Atimarala). Though the foreign equivalent of the term is unknown, the likelihood that it is a loanword is credible for two reasons. Firstly, the type could be a transliteration of the English word admiral. Secondly, the use of the consonant $r$, which along with $h$ and $k$, were introduced to accommodate foreign words. 'Atimarala is obsolete today and has become replaced with Fa'aola (Saviour). This brings forth an interesting development. That is, through time, even foreign types, which have long lexical existence in the gagana, can become less favourable to speakers and thus become unused and replaced by another term.

The types pouliuli and talisuaga are existing terms which have had new meanings added. Pouliuli, for instance, was only used to mean darkness in pre-contact Sāmoa. The acceptance of Christianity and its teachings, however, introduced the idea of heathen, which is the foreign meaning added. Talisuaga, which is from the indigenous and respect term talisua (feast), has a new semantic meaning added (eucharist). 
The types matā 'upu silisili and ola fou are a combination of existing (e.g. silisili, ola and fou) and foreign (e.g. mataupu) used to accomodate a foreign meaning. The type matā' 'upu silisili was coined within the Church's religious and educational contexts. Sermons, for instance, are considered lāuga about matā 'upu silisili. Like matā 'upu silisili, the type ola fou is also coined to exemplify Christian beliefs, this time about the afterlife. The narrative shift from local beliefs about the afterlife, where pulotu was considered to be the abode for departed spirits (Geraghty, 1993, p. 345) to a heavenly abode exemplifies the lexical and social shifts.

Overall, types in the RC category are a combination of physical, spiritual and educational activities centred around church and religion.

\subsection{5) Social Culture}

A variety of sub-categories constitute the SC category for Sulu 1944. The majority of types, though, are linked to administration governance rather than church governance, particularly in the areas of occupation and education.

Types such as mālō (government), Tupu (foreign leader-4 tokens), leoleo (police officer), fa 'amasino (court judge) and Unitaria (Unitarian) are government related types. Collocated with Unitāria is Terinetālia (Transcendentalism-1 token). A 'oa 'oga (education), matā 'upu (school subject), laina (line) and kolisi (college) are education related types.

Numbers and time emerge, also. These are evident in the types 'afa (half-1 token) and afe (thousand -1 token). Many time related types were found such as itūla (hour) -4 tokens), tausaga (year-11 tokens) and māsina (month-1 token).

But the most frequently used type is ' $u p u$ (written/published word) with 30 tokens. Often used to signify reverence, 'upu is collocated in phrases about the scriptures. Closely associated with the print texts is the type ulutala (story heading - 3 tokens).

Celebratory types such as Senetenari (church centenary-7 tokens) and Iupelī (church jubilee - 2 tokens) also appear. These types were collocated with phrases about the 100 year celebrations of Samoa's first theological institute, Mālua Theological College (MTC), to take place in 1947.

The most frequently used types are as follows:
- 'ири
(word)
30 tokens
- $a$ 'oa'oga (education)
28 tokens 

- $m \bar{a} l \bar{o}$
(government) 13 tokens
- Unitāria (United)
11 tokens
- tausaga (year)
11 tokens

Compared to the SC category in Sulu 1906, the withdrawal of the German administration in 1914 resulted in the discontinuation of types such as Kaisa, Kaisalina and Kaisalika. While the SC types in Sulu 1906 depicted a nation in the midst of entrepreneurship, Sulu 1944 SC types yields a picture of a nation immersed in the administrative supervision of New Zealand.

Of the 25 foreign types identified, 9 new foreign types emerged:

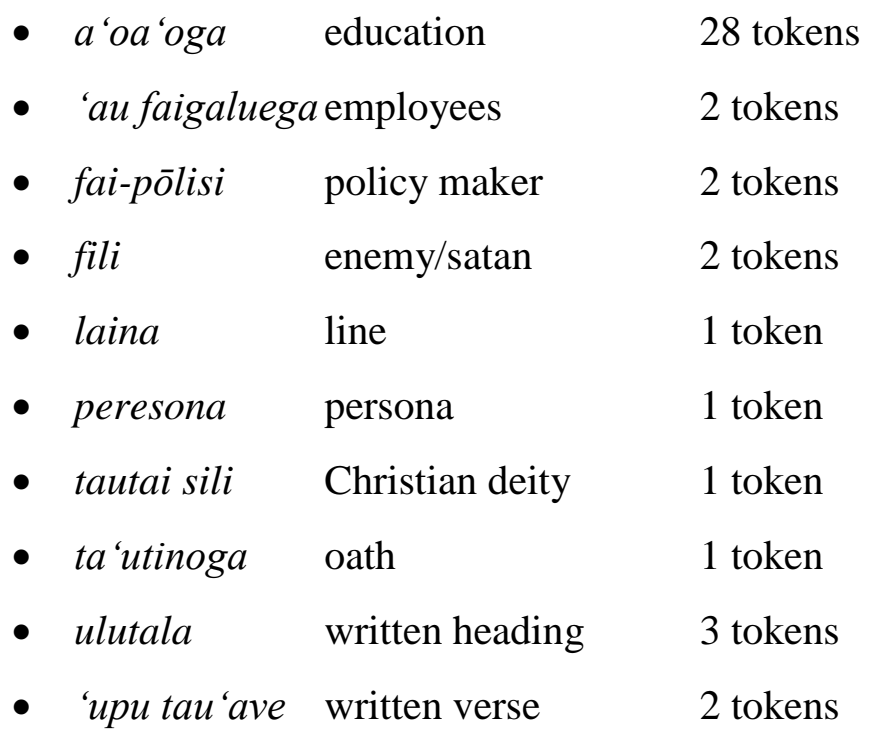

Collocations of the type $a^{\prime}$ 'oa'oga were either based on government or church schools. The shift from $\bar{a} \operatorname{og} a$ as a materialistic entity to a more socially endorsed and relevant practice is highlighted here.

Types such as laina, ulutala and 'upu tau'ave are directly associated with education. While laina and ulutala are self-explanatory, the type 'upu tau'ave is an interesting one. When used, it refers to a set or assigned passage. Assigned daily biblical passages, for instance, can be known as 'upu tau'ave. Of further interest is the idea that a similar type emerged in Sulu 1906 called 'uри fa' 'amau. 'Upu fa 'amau was used to mean a biblical verse. The use of 'upu fa' 'amau in 1906 and emergence of 'upu tau 'ave in 1944, both meaning an assigned verse, can either be explained as a lexical expansion or replacement. 
The extension of the type 'au faigaluega, which was discussed in Section 5.8.4 to refer to a clergy group, is used here to mean employees. Another lexical extension, which adds to the already comprehensive list of coined words for the Christian deity, is the type tautai sili. The type means main leader. The type peresona is used to address the trinity profiles of the Christian deity.

The type fai pōlisi is an interesting new development, also. Fai means to do. Pōlisi, however, is a loanword for the type policy. In Section 5.7.5, the type fai-tūläfono emerged as one of the new foreign types introduced under the SC in Sāvali 1944. These lexical developments point to the adoption of foreign socio-political institutions and their associated vocabularies. Faitūläfono and fai-pōlisi are significant markers in this process of deliberate governmental transition from a Samoan-dominated political system to a foreign-dominated political system.

\subsection{6) Material World}

Twelve types (13\%) were categorised under Material World. Some interesting ones include:

- fa'afanua (map)

- 'ófisa (office)

- Fale au'upega (gun store)

- Ma'a fa'amanatu (head stone) 1 token
2 tokens $\bullet$ nila

1 token $\bullet$ sofa

1 token

- uaina

- va'alotu (needle) 1 token

(sofa) $\quad 1$ token

(wine) $\quad 1$ token

(mission boat) 1 token

Collocations with fa' afanua point to a discussion about the skill of cartography. Fale 'auupega and ma' $a$ fa' 'amanatu were both used to refer to a gun shop and head stone respectively. The type va 'alotu refers to mission boats used by the missionaries for intra-island sea travels. This particular type is no longer used as inter-island travel for the purposes of missionisation has waned.

Of the 12 foreign types, eight new foreign types were identified. In order of the highest to the lowest frequency, these are:

- $k e s i$

desk

- $k o l i s i$

college

- $m a$ 'a

fa'amanatu headstone
7 tokens

2 tokens

1 token 
- fale 'aunpega weapons store 1 token

- nila needle 1 token

- sitepu step 1 token

- sofa sofa 1 token

- uaina wine 1 token

Types under the MW category range from food (uaina), building (kolisi, fale au 'upega and sitepu), funeral (ma'a fa' 'amanatu), clothing (nila) and furniture (kesi and sofa). Compared to 1906, the eight new types mark the existence of new foreign goods, which reflect the opening up of Samoa's economy and society to more material changes.

A closer examination of these words indicate that only ma' a fa 'amanatu and fale 'auupega are not loanwords ${ }^{23}$. To unpack, ma 'a fa' amanatu consists of the existing words $m a$ ' $a$ (stone) and fa 'amanatu (remembrance). The type fale au 'upega consists of the existing words fale (house) and au 'upega (weapons). As will be discussed in section 6.3 of Chapter Six, foreign types are integrated varyingly into the gagana through various lexical processes.

\subsection{7) Natural Environment}

The natural environment is represented by only two types:
- ‘ $a p u$
(apple)
5 tokens
- pāneta (planet)
3 tokens

Both types were collocated with Biblical references. ' $A p u$, for instance, was used to refer to the Genesis story. Both types were also new words which have emerged in 1944.

\subsection{8) Other}

There were no new foreign types for the OTH category in this indicator year.

5.8.9) Overview of Sulu 1944 findings

${ }^{23}$ See section 3.8 .8 of Chapter Three 
Foreign word use in 1944 remains congregated around religious and social culture and proper nouns. Like 1906, very few foreign types to do with the Natural Environment and Other categories appeared.

One of the main reasons for the low representation of foreign types in 1944 was due to the lack of coverage and mention of significant social events in Sāmoa which involved Samoans at the time in the newspapers. The withdrawal of the Germans from Sāmoa was not mentioned. Neither was World War II, which had involved many sons of Sāmoa and did not end till 1945. The lack of coverage about the tensions between the NZA and Samoan people, which lead to Sāmoa becoming a mandate territory, was also neglected. Lāuga in Sulu also failed to mention any the above. In addition to this, the prioritisation to document and communicate civil disputes about land and titles in lāuga sources in Sāvali, resulted in a low ratio of foreign types.

The next sections (5.9-5.10) continues the current discussion about new foreign types in both Sāvali and Sulu for the 1977 indicator year.

\section{9) SĀVALI 1977 FILES:}

Table 12 presents a categorical break-down of foreign types and tokens for the file.

Table 12:

Categories/Types/Tokens: Sāvali 1977

\begin{tabular}{|c|c|c|c|c|}
\hline \multicolumn{5}{|c|}{ Sāvali 1977} \\
\hline Categories & Types & $\%$ & Tokens & $\%$ \\
\hline 1. Place Names & 15 & 5 & 25 & 1 \\
\hline 2. Proper Nouns & 115 & 38 & 332 & 12 \\
\hline 3. Religious Culture & 5 & 2 & 111 & 4 \\
\hline 4. Social Culture & 94 & 31 & 2133 & 74 \\
\hline 5. Material World & 53 & 18 & 244 & 8 \\
\hline 6. Natural Environment & 17 & 6 & 22 & 1 \\
\hline 7. Other & 0 & 0 & 0 & 0 \\
\hline Total & 299 & 100 & 2867 & 100 \\
\hline
\end{tabular}

\subsection{1) Table 12 Analysis}


A total of 299 foreign types were found in this issue of Sāvali. The most striking feature of Table 12 is the influx of foreign types in the PN (115 types), SC (94 types) and MW (53 types) categories. Worth mentioning, particularly when compared to its low type numbers for 1906 and 1944 is the increase in NE (17 types) foreign types. Interestingly, there is a considerable drop in RC types (5 types-2\%) for this indicator year. A more in-depth discussion about the respective categories for Sāvali 1977 is provided in Sections 5.9.2—5.9.8.

\subsection{2) Place Names}

With a total of 15 types and attributing only $5 \%$ of the total foreign types for Sāvali 1977, there has been an increase in foreign PLN types: A comparison is provided below:

$\begin{array}{rccccc}\text { Foreign PLNs: } & \text { Ind/Year } & \text { Types } & \% & \text { Tokens } & \% \\ 1906 & 10 & 9 & 23 & 4 \\ 1944 & 6 & 6 & 18 & 3 \\ 1977 & 15 & 5 & 25 & 1\end{array}$

With two additional sub-categories added in 1977 (Asia and Africa), the geographical attribution of PLNS in 1977 is similar to 1944. PLNs in 1977 are categorised under the following geographical areas:

- Americas (4 types) 6 tokens

- Europe

(4 types)

- Pacific

(3 types) $\quad 5$ tokens
- Middle East (2 types)

- Asia

- Africa
(1 types) 1 tokens

(1 type) $\quad 1$ token

There were more PLNs from the Americas than any other geographical area. The Americas is represented by Niu Ioka (New York-2 tokens), Kānata (Canada—2 tokens), Sana Faranisiko (San Francisco-1 token) and Unaite Setete 'o 'Amerika (United States of America-1 token). Like 1944, there is a low representation of Pacific PLNs in 1977. The most frequently used Pacific PLNs in 1977 are Pāpua Niu Kini (Papua New Guinea) and 'Ausetalia (Australia) with 2 tokens each and Meleisia (Malaysia) (1 token). 
The additional Asian and African PLNs accounted for only two types Aferika (Africa-1 token) and Iäpani (Japan-1 token). Europe is represented by the types Peretānia (Britain), Rusia (Russia), Falani (France) and Siāmani (Germany) accounted for a total of six tokens. The Middle East is represented by 'Aikupito (Egypt-1 token) and 'Árapi (Arab-1 token).

Some interesting observations and comparisons to be made here. Firstly, there is a shift in the collocation of Pacific PLNs. While in 1944 Pacific PLNs were collocated referring to the establishment and growth of Christianity in Sāmoa and the Pacific, Pacific PLNs in 1977 are collocated to indicate development both locally and in the wider Pacific. These are evident in the phrases fono 'i Ра̄pиa Niu Kini (meeting in Papua New Guinea), 'oloa 'i Ausetalia (goods to Australia) and pālemia 'o Meleisia (Malaysia's prime minister). This shift has led to a decrease in PLNs with a degree of religious connection.

The uses of foreign types under Americas are also governance related. For example, Kānata is collocated in the phrase Usugāfono Faipule mō Känata (mayoral delegates for Canada) and fonotaga fa 'apalemene e faia i Kānata (World Leaders forum to be held in Canada).

The general collocation of foreign types in the PLN category point to both local and international development and governance.

The five new types PLN found in this issue of Sāvali are Levuka (Levuka), Meleisia (Malaysia), Niu Ioka (New York), Pāpua Niu Kini (Papua New Guinea) and Kānata (Canada).

The Pacific is represented by Levuka and Päpua Niu Kini. Niu Ioka and Känata represent the Americas. Representing Asia is Meleisia. Collectively, all new PLN types were collocated in passages about Samoa's growing involvement in international politics. The general collocation of foreign types in the PLN category point to Samoa's local and international development and governance.

\subsection{3) Proper Nouns}

Comprising 38\% (115) of total types and 12\% (332) of total tokens, PNs are sub-categorised into the following areas:

- People names: 107 types

- Months/days:
5 types
- Denomination:

- Deity names:
2 types

1 types 
With only four people names in Sāvali 1944, the 107 people names in 1977 indicates a substantial increase. With the exception of 'Isikuki and 'Isitolo (Tongan origin), all people names are of European origin. Names include Iērome (Jerome), Ieti (Jed), Ioapo (Joab) and Iona (Jonah). The most frequent person name is Ioane (John-17 tokens). While Ioane is used widely by Samoan denominations, names which exemplify denominational differentiation include Pelenato (Bernard), Veronika (Veronica), Sānele (Chanel), Peneueta, Ponifasio and Pelenātete, which are all Catholic names. Uesilī (Wesley) and Sione (John) are common Methodist names.

But while people names impart the most number of types, the most frequently used type, however, is the month Sêtema (September-43 tokens). The high frequency of Sêtema is accounted to a considerable amount of land and title cases summoned for that month. In comparison, the type L.M.S (38 tokens), pronounced $L \bar{a} M \bar{o} S \bar{a}$, had the highest frequency in Sāvali 1944 due its use in church fundraising notices. Based on these two examples, type frequency is correlated to and often determined by significant social events.

One of the interesting observations made in previous Sāvali was the high frequency of religious proper nouns such as Atua and Katoliko. This has changed in 1977, where deity and denomination PNs are less represented. Atua, though not a new type, for instance, is used only once. The type Iesu Keriso (Jesus Christ) and Katoliko are the same. On another note, the emergence of the type 'Ekālesia 'o le 'Aupa'ia e Gata Ai and Lotu Patipati are the first Samoan non-mainstream denomination types to appear in the entire corpus.

The orthographic inconsistencies of some types, such as Pēteru and Pētelu (Peter) highlight two points. Firstly, that in 1977, consonants considered informal in speech discourse, such as $l$ and $k$ (see Pēteru and Pételu), were being used in the published domain. However, this disparity can in fact be considered as not an inconsistency, but rather as a justification tool for denominational distinction and ascendancy. For example, Pèteru and Pètelu are types commonly associated in print to Samoan Congregationalism and Catholicism, respectively.

Of the 115 foreign types, 110 are new types. These are sub-categorised into the following areas:

- People names: 95 types

- Institutions:

10 types

- Denomination:
- Day:

- Deity name:

- Bible chapter:
1 type

1 type

1 typ 
For a category to increase immensely points to a major social change. This social change is the transition from a mandate territory in 1944 to national independence in 1962. The majority of people names, however, are Biblical names, such as 'Ápelu (Abel), Iona (Jonah), 'Eseta (Esther) and Kālepo (Caleb).

A few Catholic names appear, such as Felela (from the French word frere), Iêrome (Jerome), Iōsefo (Joseph), which is transliterated in the Congregational denomination as Iōsefa. Other Catholic names include Mikāele (Michael), Pelenātete (Benedict), Pelenato (Bernard) and Pètelo (Peter). Like Iōsefo and Iōsefa, the English name Peter is transliterated as Pèteru in the Congregational denomination. These two examples highlight how language differs between denominations.

Names that do not have Biblical origins but appear are Laneselota (Lancelot), Livigisitone (Livingston), Pisimaka (Bismark), Sālesa (Charles), Keti (Katie), Mōlesi (Morris) and Pati (Pat). All of these types are indeed European names, which may indicate the influence of Germany, Britain and New Zealand as Samoa's former administrators.

The two denominations mentioned are 'Ekālesia 'o le 'Au Pa'ia e Gata Ai (Mormonism) and Lotu Patipati (Assembly of God). The use of these two denominations indicate the addition of new denominations added to the three mainstream churches of Lotu Ta iti, Metotisi and Katoliko. Important to note here is that the Lotu Mãmona (Latter Day Saints-LDS) was established in Sāmoa in 1894. However, there is no mention of LDS in either newspapers.

Other types include Aso Sāpati (Sunday), Iesu Keriso (Jesus Christ) and Fa'aaliga (Revelations). These types represented the Day, Deity name and Bible Chapter, respectively.

The most frequently used type in this category is Fa'aaliga with 41 tokens. This is followed by Màlō 'Aufa' atasi (Commonwealth) with 19 tokens and 'Ema (Emma) with 13 tokens.

The imbalance between secular (people names and months/day) and non-secular (denomination and deity names) portrays a newspaper indicative of the changing social and religious contexts of Sāmoa in 1977.

\subsection{4) Religious Culture}

The five types that appear in the RC category are as follows:
- 'éseta
(easter)
12 tokens
- fa' aipoipo
(marriage) 79 tokens 
- usugāfono (delegates) 17 tokens $\quad$ pouliuli $^{24}$ (non-ecclesiastical) 1 token

- felela (Brother) 2 tokens

Worth mentioning here is the collocation of the type 'éseta to refer to a public holiday (aso màlōlō 'o le 'êseta - easter public holiday). Also, the use of the type fa'aipoipo no longer references the formalities of the ceremony, but rather the lawful state of marriage under the government. This is reflected in the phrases avā fa 'aipoipo (legal wife) and fānau fa 'aipoipo (legal children).

The Catholic-related type felela, is a transliteration of the French word frere, meaning brother, is used for the first time. The type felela is rarely heard in Samoan speech nowadays if at all, particuarly amongst Catholics. This is because the status is no longer a position in Samoan Catholicsm today. The type fesoasoani, meaning Catholic catechist has become more favoured by Samoans. A more in-depth discussion of the type fesoasoani is provided in Section 5.10.4.

The only new type that emerged is usugāfono. Used seventeen times, usugāfono is collocated to refer to the Congregational denomination's delegates to its annual General Assembly, known as Fono Tele. The type usugäfono is comprised of the existing words $u s u$, which refers to an indigenous practice of the 'ava ceremony which means to formally meet, and the word fono which means a meeting.

\subsection{5) Social Culture}

Social culture has the second most types (94) and the most tokens (2133) of any category in this file. Types are organised into the following sub-cateogries:

- tribunal

- governance

- occupation
- monetary

- education

- other

Now fifteen years into her Independence, and with obligations to foreign involvement and interests, many government departments were created aimed to serve both local and international relations. As a result, vocabularies were constructed to accommodate these

${ }^{24}$ Can also refer to mean 'heathen'. 
changes. Organised into governance, tribunal, indemnity and Other categories, 1977 Sāvali displays a wide range of introduced types into the gagana. But perhaps the most telling observation in this category is that 58 new words emerged in 1977 that were not used in 1944. The foreign types that appeared in 1944 and 1977 are types such as 'ófisa (office), pālemia (prime minister), kāpeneta (cabinet) and fa 'atonu (director). These types, however, are not new types.

There are a range of new types that were identified in Sāvali 1977. Tables 13, 14 and 15 illustrate the vast amounts of new words found:

Table 13:

Governance Types

\begin{tabular}{|c|c|}
\hline Type & Translation \\
\hline $\begin{array}{l}\text { - Fa'alāpotopotoga tau } \\
\text { A'oa 'oga Saienisi ma Aganu'u }\end{array}$ & $\begin{array}{l}\text { United Nations Educational, Scientific } \\
\text { and Cultural Organisation (UNESCO) }\end{array}$ \\
\hline $\begin{array}{l}\text { - Fa'alāpotopotoga tau } \\
\text { Mea'ai ma Fa'ato 'aga }\end{array}$ & $\begin{array}{c}\text { Food and Agriculture Organisation of } \\
\text { the United Nations (FAO) }\end{array}$ \\
\hline $\begin{array}{l}\text { - Fa'alāpotopotoga tau le } \\
\text { Soifua Mālōlōina }\end{array}$ & Word Health Organisation (WHO) \\
\hline - Fa'atonu Sili & Chief Executive Officer \\
\hline - fa'atonu tusitala & lead editor \\
\hline - Failautusi & Government Clerk \\
\hline - Felafolafoa 'iga Fa'alaua 'itele & Conference \\
\hline - Fofoga Fetalai & Speaker of the House \\
\hline - Fono Faitūlāfono & Legislative Assembly \\
\hline - kapeneta & cabinet \\
\hline - kapineta & cabinet \\
\hline - kolone & colony \\
\hline $\begin{array}{l}\text { - Komisi Fa'apitoa Aiātatau tau Tagata } \\
\text { ma Pulega Fa'akolone Tauaofiaga a } \\
\text { Mālo 'Aufa'atasi mo Fefa'ataua 'iga } \\
\text { ma Atiina'e }\end{array}$ & $\begin{array}{c}\text { United Nations Conference on Trade } \\
\text { and Development (UNCTAD) }\end{array}$ \\
\hline - Leipa & Labour \\
\hline
\end{tabular}




\begin{tabular}{|c|c|}
\hline - Liutene & Lieutenant \\
\hline - Matāgaluega & Government Department \\
\hline $\begin{array}{l}\text { - Matāgaluega'o 'Ele'ele ma } \\
\text { Fuagāfanua }\end{array}$ & Ministry of Land and Survey \\
\hline - Minisitā 'o Fa'atoaga & Minister of Agriculture \\
\hline - 'Ofisa 'o Fanua ma Suafa & Lands and Titles Court \\
\hline - 'Ofisa o Fuagafanua & Office of Lands and Surveying \\
\hline - Perisitene & President \\
\hline $\begin{array}{l}\text { - Polokalame Atiina 'e o Mālā } \\
\text { 'Aufa'atasi }\end{array}$ & $\begin{array}{c}\text { United Nations Development } \\
\text { Programme }\end{array}$ \\
\hline - Sātini & Sergeant \\
\hline - Setete & State \\
\hline $\begin{array}{l}\text { - So ‘o 'upu Tau le Atamai i le Faiga ‘o } \\
\text { Mea }\end{array}$ & Translator \\
\hline - Sui Tōfia & Council of Deputies \\
\hline - Taupulega & Commonwealth \\
\hline - Temokarasi & Democracy \\
\hline - Tuto'atasi & Indepedence \\
\hline
\end{tabular}

Table 13 indicates that in 1977, Sāmoa was well immersed in its local and international responsibilities as an independent nation.

The majority of new types in SC category are compound words comprised of existing and foreign words. Ways in which the Samoan lexicon adapted to changes in the social environment were by either (1) transforming foreign types into Samoan form; (2) adding new meanings to existing terms to accommodate foreign meaning; and (3) initiating a combined local-foreign (loanword) system. Kapeneta, Leipa and Liutene, illustrate point 1. Mālō 'Aufa'atasi and Fofoga Fetalai are examples of process 2. Samoan types for international governing bodies, such as UNESCO, WHO and FAO, for instance, are constructed using process 2. Process 3 is evident in the phrase Fa 'alapotopotoga tau A 'oa' oga Saienisi ma Aganu 'u. Fa 'alāpotopotoga is the Samoan word used for Organisation; A'oa'oga is used for Educational; Saienisi, a loanword, is used directly for Scientific while Aganu ' $u$, an indigenous type, is used for Culture. 
This three-system process has enabled the gagana to adapt to significantly increased contact with foreign ideas and concepts ${ }^{25}$.

The gagana adapted even more so with the introduction of government institutions. One of the most influential central government institutions after independence was the Land and Titles Court (LTC). Though its origins can be traced to the Native Land and Titles Commission established by the NZA in 1924, and probably earlier to the Land Commission established by the Treaty of Berlin, land and title disputes were heightened amidst the tensions between the NZA and Samoans. For many Samoans who did not conform to the authority of the NZA, their lands were confiscated and family titles removed. Table 13 reflects the influence of this new model of settling customary disputes on Samoan vocabulary. Keeping in mind that these types are restricted to Sāvali 1977 only:

Table 14:

Tribunal types

\begin{tabular}{|l|c|}
\hline \multicolumn{1}{|c|}{ Types } & Translation \\
\hline$\bullet$ itū tete'e & defendant \\
\hline$\bullet$ fa' 'amasinoga & court of law \\
\hline$\bullet$ poloā'iga & court interim order \\
\hline$\bullet$ fa' 'ai 'uga & court verdict \\
\hline$\bullet$ talosaga & court appeal \\
\hline$\bullet$ soloia & quash \\
\hline$\bullet$ fa' 'aaliga & court notice \\
\hline$\bullet$ tūläfono & law \\
\hline$\bullet$ resitara & court registrar \\
\hline$\bullet$ itū talosaga & plaintiff \\
\hline$\bullet$ fuai 'upu & clause/law \\
\hline$\bullet$ aiā tatau & human rights \\
\hline$\bullet$ fa' 'amasino sili & chief justice \\
\hline$\bullet$ molimau & court witness \\
\hline
\end{tabular}

\footnotetext{
${ }^{25}$ See section 6.3 of Chapter Six for a detailed discussion of the Lexical Outcomes of Language Contact in the gagana Sāmoa.
} 
The use of tribunal related types is limited compared to the development of types in Table 13. For example, the majority of types in Table 14 are semantic loans, apart from the loanword resitara. There is evidence to suggest that there is a direct correlation between Westminster law processes and Samoa's indigenous forms of mediation and reconciliation. Poloà 'iga and molimau, for instance, mean order and witness in pre-contact meanings. Table 14 below illustrates more new types.

Table 15:

$\underline{\text { Monetary and Security types }}$

\begin{tabular}{|l|c|}
\hline \multicolumn{1}{|c|}{ Type } & Translation \\
\hline$\bullet$ totogi & wage/salary \\
\hline$\bullet$ läfoga & tax \\
\hline$\bullet$ tiute & customs \\
\hline$\bullet$ pule fa 'amau & lease owner \\
\hline$\bullet$ lisi & lease \\
\hline$\bullet$ tausi mavaega & custodian of \\
& inheritance/trust \\
\hline$\bullet$ mavaega & will \\
\hline$\bullet$ läfoga totogi & death tax \\
\hline$\bullet$ foa $i$ & lease \\
\hline$\bullet$ pili & bills \\
\hline$\bullet$ inisiua & insurance \\
\hline$\bullet$ läfoga a $\bar{e}$ māliliu & death tax \\
\hline$\bullet$ pasene & percent \\
\hline$\bullet$ uili & will \\
\hline
\end{tabular}

Monetary and Security types in Table 15 reflect an economically transformed Sāmoa in 1977. Capital and labour exchanges heightened a reciprocal relationship between the government, residents and citizens. As money became the engine for economic transactions, forms of payment and security became prominent.

Other areas that appeared in the files are types categorised broadly under education, occupation and communication. 


\begin{tabular}{|c|c|c|c|c|c|}
\hline - fa'asilasilaga & advertisement & 37 tokens & - tuātusi & address & 3 tokens \\
\hline - pisinisi & business & 11 tokens & - $a^{\prime} \circ a^{\prime} \operatorname{og} a$ & education & 2 tokens \\
\hline - faigaluega & occupation & 8 tokens & - kāmuta & carpenter & 1 token \\
\hline - lōmiga & print issue & 6 tokens & - kuka & cook (noun) & 1 token \\
\hline • su'ega & exam & 6 tokens & - matatā 'ese'ese & polytechnic & 1 token \\
\hline $\operatorname{togi}$ & grade & 6 tokens & - pasene & percent & 1 token \\
\hline - faiā'oga & teacher & 5 tokens & - 'otometi & automatic & 1 token \\
\hline - polōkalame & programme & 4 tokens & - saienisi & science & 1 token \\
\hline - parakalafa & paragraph & 3 tokens & & & \\
\hline
\end{tabular}

For the SC category, there are more foreign types used in 1977 than in 1944. An increase in government related terms has provided a glimpse of Sāmoa being an independent nation state now immersed in the fusion between local and foreign governance ideologies and institutions.

\subsection{6) Material World}

The indicator years 1906, 1944 and 1977 show an increase in types and tokens for Material World. In 1906, MW types were widely associated with wealth (gold, silver, money) and education (school, education, books). 1944 revealed MW types to be aligned under the subcategories building (church, office, school, post shop) and currency (money, shilling, dollar, cent, dime and silver). In 1977, with a vast increase of types accounting for 18\% (53) of the total types and $8 \%$ (244) of total tokens, this has resulted in a diverse MW category. Some of the types are listed below:

\section{Buildings:}

- fale 'apa (tin roof house) 8 tokens

- fale (European papālagi house)

- Kolisi (college) 5 token

- falemeli (post shop) 2 tokens

- māketi (market 2 tokens
- Iunivesitē (university) 2 tokens

- faletupe (bank) 1 token

- fale (hotel) 1 token talimālōo

- kamupanī (company) 1 token

- malae (airport) 1 token va'alele 
- maota fono (parliament) 1 token

Communication:

- telefoni (telephone) 16 tokens

- niusipepa (newspaper) 7 tokens

- pepa (paper) 6 tokens

- fa'afanua (map) 3 tokens

- uati (watch) 3 tokens

- laupepa (page) 2 tokens

\section{Currency:}

- tupe maua (profit) 2 tokens

\section{Transport:}

- ala tele o le

Mālō (public road) 5 tokens

- laisene (license) 5 tokens

- afi (engine) 4 tokens
- meli (mail) 2 tokens

- faila (file) 1 token

- lipoti (report) 1 token

- pepa maliu (death certificate) 1 token

- pusa (mail box) 1 token

- sēleni (shilling) 1 token

- masini (machine) 4 tokens

- va'alele (aircraft) 4 tokens

- pasi (bus) 2 tokens

- ta'avale (car) 2 tokens

Land:

- 'Eka (acre) 15 tokens

- esetete (estate) 13 tokens

- $p \bar{a}$ povi (cow farm) 3 tokens
- $p \bar{a}$ pua'a (pig sty) 1 token

- fa'ato'aga (plantation) 1 token

Food:

- suka

sugar)

3 token
- 'èleni (tinned fish) 1 token

Misellaneous: 


\begin{tabular}{llllll} 
- 'ema & (ember) & 13 tokens & $\bullet$ u'amea & (metal) & 1 token \\
- 'oloa & (goods) & 5 tokens & - fagavao & (weed spray) & 1 token \\
- paipa & (pipe) & 4 tokens & - fetalaisa & (fertiliser) & 1 token \\
- tane & (water tank) & 3 tokens & - mea & (tools) & 1 token \\
- tioata & (mirror) & 1 token & \multicolumn{2}{c}{ faigaluega }
\end{tabular}

Of the 53 foreign types in the MC category in 1977, 36 new types emerged. Some are listed as follows:

Buildings:

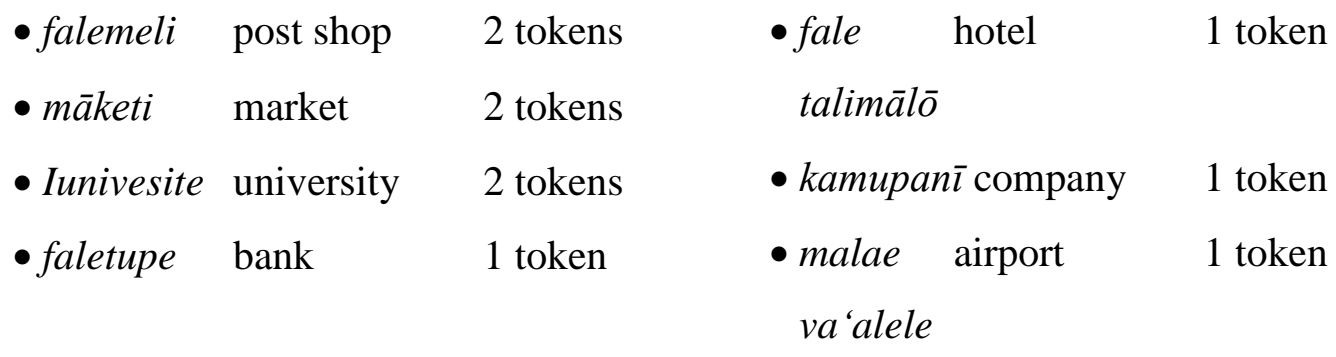

Communication:

$\begin{array}{llllll}\text { - telefoni } & \text { telephone } & 16 \text { tokens } & \bullet \text { faila file } & 1 \text { token } \\ \text { - pepa } & \text { paper } & 6 \text { tokens } & \text { - lipoti } & \text { report } & 1 \text { token } \\ \text { - fa'afanua } & \text { map } & 3 \text { tokens } & \text { - pepa maliu death } & \\ \text { - uati } & \text { watch } & 3 \text { tokens } & & \text { certificate } & 1 \text { token } \\ \text { - laupepa } & \text { page } & 2 \text { tokens } & \text { - pusa } & \text { mail box } & 1 \text { token }\end{array}$

\section{Currency:}

- tupe maua profit 2 tokens

Transport:

- ala tele 'o le Màlō public road 5 tokens

- laisene license 5 token
- masini

- va'alele

- pasi machine

aircraft

bus
4 tokens

4 tokens

2 tokens 
Agriculture:

- 'Eka acre

15 tokens

- pā pua'a

pig sty

1 token

- esetete

estate

13 tokens

- fa' 'ato 'aga

plantation

1 token

- $p \bar{a}$ povi $\quad$ cow farm 3 tokens

Food:

- suka

sugar

3 tokens

• 'ēleni

tinned fish 1 token

Miscellaneous:

- 'ema ember

13 tokens

- tioata

glass

1 token

- 'oloa goods

5 tokens

- fagavao

weed spray 1 token

- paipa

pipe

4 tokens

- fetalaisa

fertiliser

1 token

- tane

water tank 3 tokens

Samoa's MW in 1977 reflects its dynamic SC environment outlined in Section 5.9.5. The upsurge in central governance responsibilites both locally and internationally led to considerable infrastructure and resource development to functionalise social roles. This point is evident in the use of types such as falemeli, iunivesitē, faletupe, faletalimālō, kamupanī and malae va'alele.

Economic development, including the setting up of the infrastructure for commercialisation is demonstrated through housing words ('eka, esetete, faletalimālō), transport (malae va 'alele, va'alele, ala tele 'o le Mālō, laisene, pasi), communication technologies (telefoni, līpoti, pusa ${ }^{26}$ ), agriculture (pā povi, pā pua'a, fa'ato'aga, fagavao, fetalaisa,) and health (tane, paipa). These increases in infrastructure and resources required also human resources and skills, thus initiating paid employment opportunities (tupe maua).

Sāvali 1977 has delineated Sāmoa as a nation whereby its material resources reflect its societal development or modernisation. With a decrease in Religious Culture types (see Section 5.9.4),

\footnotetext{
${ }^{26}$ Geraghty \& Tent (1997) in their article titled "More Dutch Loanwords in Polynesia" have found evidence to support that the word "pusa", which is found in most Polynesian languages, is a transliteration of the Dutch word "busa" (box).
} 
the year 1977 demonstrates the dramatic rise, influence and authority of the independent nation-state.

\subsection{7) Natural Environment}

With a total of 17 foreign types, this particular indicator year contributed the most foreign types to do with the NE category. The generality of types are to do with agriculture:

Animals:

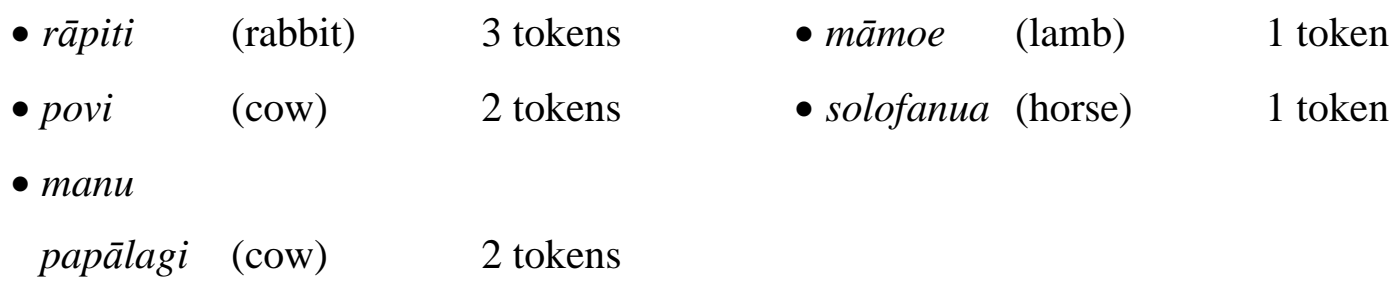

Fruit/Vegetables:

$\begin{array}{llllll}\text { - koko } & \text { (cocoa) } & 2 \text { tokens } & \bullet \text { maukeni } & \text { (pumpkin) } & 1 \text { token } \\ \text { - } \text { aniani } & \text { (onion) } & 1 \text { token } & \bullet \text { meleni } & \text { (melon) } & 1 \text { token } \\ \text { - fuāmoa } & \text { (egg) } & 1 \text { token } & \bullet p \bar{\imath} & \text { (pea) } & 1 \text { token } \\ \text { - lāitisi } & \text { (lettuce) } & 1 \text { token } & \bullet \text { tamato } & \text { (tomato) } & 1 \text { token } \\ \text { - kāpisi } & \text { (cabbage) } & 1 \text { token } & \bullet \text { tīpolo } & \text { (lemon) } & 1 \text { token }\end{array}$

- manioka (manioc-root) 1 token

Natural resources:

- vaipaipa (tap water) 1 token

Of the 17 foreign types identified, 11 are new types: These are listed as follows:

- esetete estate

- fuāmoa egg

- lātisi lettuce

- manioka manioc
13 tokens

1 token

1 token

1 token
- тапи papālagi cow 2 tokens

- maukeni pumpkin 1 token

- meleni melon 1 token

- moa chicken 1 token 
- pua'a pig

2 tokens

- tamato tomato

1 token

- rāpiti rabbit 3 tokens

Types in NE are heavy on the development of local agriculture. The most frequently used type is esetete. Note how manu papālagi means cow. This word was coined as a respect term for cow which is commonly used in Samoan gifting practices. Apart from manu papālagi, the remaining types are transliterations. Note how some types, such as pua' $a$ and maukeni are transliterations of these respective types from other Pacific languages. Pua ' $a$, for instance, may have been integrated from Tongan where pig is spelled puaka, or it could have been the reverse.

\subsection{8) Other}

There are no foreign types for the OTH category in Sāvali 1977.

\subsection{9) Overview of Sāvali 1977 findings}

The multiplication of types in Sāvali 1977 reflected the striking social and material changes during the period. Most of these changes were a result of the increase in Samoa's local and international governance obligations. The development and growth of local centralised infrastructures and human resources and skills was now a priority for this modernising nation. One of the interesting observations made from the Sāvali 1977 file was the dramatic decrease in RC types. Could this be the case for Sulu $1977 ?$

\subsection{0) SULU 1977 FILES:}

Table 16 presents a categorical break-down of foreign types for the file.

Table 16:

Categories/Types/Tokens: Sulu 1977

\begin{tabular}{|c|c|c|c|c|}
\hline \multicolumn{5}{|c|}{ Sulu 1977} \\
\hline Categories & Types & $\%$ & Tokens & $\%$ \\
\hline 1. Place Names & 13 & 11 & 22 & 7 \\
\hline 2. Proper Nouns & 42 & 35 & 163 & 53 \\
\hline 3. Religious Culture & 20 & 17 & 45 & 14 \\
\hline
\end{tabular}




\begin{tabular}{|c|c|c|c|c|}
\hline 4. Social Culture & 23 & 19 & 46 & 15 \\
\hline 5. Material World & 19 & 16 & 24 & 9 \\
\hline 6. Natural Environment & 3 & 2 & 7 & 2 \\
\hline 7. Other & 0 & 0 & 0 & 0 \\
\hline Total & 120 & 100 & 307 & 100 \\
\hline
\end{tabular}

\subsection{1) Table 16 Analysis}

While there has been a decrease in foreign types since 1906, an examination of Sulu types and tokens from the files 1906, 1944 and 1977 indicate a steadying of foreign types from 1944 and 1977.

$\begin{array}{rccccc}\text { Foreign PLNs: } & \text { Ind/Year } & \text { Types } & \begin{array}{c}\text { \% of all } \\ \text { Sulu Types }\end{array} & \text { Tokens } & \begin{array}{c}\text { \% of all } \\ \text { Sulu } \\ \text { tokens }\end{array} \\ & & & & 2868 & 50 \\ 1906 & 446 & 46 & 735 & 13 \\ 1944 & 93 & 9 & 307 & 5\end{array}$

\subsection{2) Place Names}

Since 1906, a considerable decrease in the use of PLNs in the Sulu is evident. It is highly likely due to various reasons such as the discontinuation of Samoan missionary work in the Pacific as denominational development and growth became self-governed. Missionary work by Samoans in the Pacific, including written reports about their work overseas, therefore, ceased. There are a total of 13 PLNs, accounting for $11 \%$ of the total types in the Sulu 1977 file. With 22 tokens, PLNs only accounted for $7 \%$ of the total tokens. PLNs are attributed to the following geographical areas:

- Pacific

- Americas

- Middle East

- Europe 
The most frequently used types are 'Amerika (America - 6 tokens), Roma (Rome -5 tokens) and Kuatemala (Guatemala-4 tokens). The type Kuatemala is used in reference to the Guatemala canal in Central America. The New Zealand cities of 'Aukilani (Auckland-one token) and Kalaisetete (Chrischurch-2 tokens) are correlated to continued partnerships between Sāmoa and New Zealand which was formalised in the signing of the Treaty of Friendship in 1962. 'Aukilani, in particular, even by 1977, had a significant Samoan population.

An interesting variation of the type Ierusalema (Jerusalem) is spelled as Kelesema. New types that emerge are Sietale (Seattle) and Uossigitone (Washington). While the type Ierusalema remains biblically connected, Sietale and Uōsigitone are collocated to reference Samoans' diasporic movements to these areas in America.

Of the 13 foreign PLNs, twelve are new types. The type that was recorded in 1944 is Ierusalema. The twelve new types are as follows:

- 'Aukilani Auckland 1 token

- Kīsona Kishon 1 token

- Kuatemala Guatemala 1 token

- Peretiso Paradise 1 token

- Petānia Bethany 1 token

- Ruelu Ruel 1 token
- Tesālonia Thessalonians 1 token

- Ueselē Wales 1 token

- Uōsigitone Washington 1 token

- Kaisareia Kaiseria 1 token

- Kalifōnia California 1 token

- Kalaisetete Christchurch 2 tokens

Apart from Kalaisetete, which was used twice, all type frequencies totalled to one respectively. All types are loanwords. This latter observation indicates the continued relevance of the Bible to the religious discourse. The emergence of 'Aukilani and Kalaisetete is related to the increase of Samoan migration patterns to these metropolitan centres. Another interesting type worthy of mention is the word Peretiso, which makes reference to heaven as paradise. Today, this type is spelt as parataiso.

\subsection{3) Proper Nouns}

While PLNs have decreased in usage in Sulu over the years, PNs have maintained a consistent amount of types. Contributing the most types (42) and tokens (163) for the file, PNs are categorised into the following sub-categories:

- People names (24 types) 119 tokens $\quad$ Bible Chapters $\quad$ (13 types) 31 tokens 
- Nationality (3 types) $\quad 9$ tokens $\quad$ Denomination $\quad$ (4 types) 4 tokens

Though people names have the majority types, there is an increase of references to Bible chapters. Nationality was an interesting sub-category with the use of Sä Keniselī (Keniseth people) and $S \bar{a}$ 'Isarā' $e l u$ (Israelites). The translation of Congregational Christian Church of Sāmoa, 'Ekālesia Fa'apotopotoga Kerisiano Sāmoa (EFKS) is referenced for the first time in the EFKS owned Sulu. Another interesting type is the word Peretiso, which makes reference to heaven as paradise.

Of the 42 foreign types, 31 are new types. The majority of PNs are people names such as Iériko (Jerico), Makatala (Magdalene), Pārapa (Barab), Fereti (Fred), Peletisara (?) and Pīlato (Pilate). The most frequently used type is Pārapa with 13 tokens. Because most of the types are Bible names, their collocations were mainly Biblical.

The translation of Congregational Christian Church of Sāmoa, 'Ekālesia Fa'apotopotoga Kerisiano Sämoa (EFKS) is referenced for the first time in the EFKS owned Sulu. This type is coined from a combination of existing and foreign words. To point out, 'Ekālesia and Kerisiano are loanwords from the English words ecclesiastic and Christian. Fa 'apotopotoga is an existing word meaning a congregation or a group of people.

\subsection{4) Religious Culture}

In the RC category, 20 foreign types were identified. Similar to 1906 and 1944, types orient towards church status, worship and religiosity. Types such as ti'ākono (deacon), faife 'au (pastor) and $a$ 'oa'o (lay preacher) are some examples.

Of the 20 foreign types, seven are new types:

$\begin{array}{lll}\text { - } \text { a'oa'ofesoasoani } & \text { lay preacher } & 17 \text { tokens } \\ \text { - } \quad \text { 'au sā'ili } & \text { youth group } & 1 \text { token } \\ \text { - } t i \text { 'ákono tinā } & \text { female deacon } & 1 \text { token } \\ \text { - fa'aolataga } & \text { salvation } & 2 \text { tokens } \\ \text { - faitaulaga sili } & \text { Christian deity } & 1 \text { token } \\ \text { - } \text { ola e fa'avavau } & \text { eternal life } & 2 \text { tokens } \\ \text { - têvolo } & \text { devil } & 7 \text { tokens }\end{array}$


1977 resulted in the extension of some types such as a 'oa 'o (lay preacher) to a 'oa 'o fesoasoani. The word fesoasoani means assistant or helper. The distinguishing of religious roles in church such as a'oa'o (lay preacher) from faife 'au (pastor), for instance, is evident here. The type faitaulaga, which was used in 1906 to mean the act of donating, has also been extended to Faitaulaga Sili. This time, however, Faitaulaga Sili is used to refer to the Christian deity. This is a new foreign type addition to deity names, which as stated previously, continues a lexical expansion tradition of coining new types for a higher power

The religious role of $t i{ }^{\prime} \bar{a} k o n o$ (deacon) is also extended and collocated with $t i{ }^{\prime} \bar{a} k o n o$ tina (women deacons). $\mathrm{Ti}$ ' $a$ kono is an interesting type because it brings forth for the first time the notion of gender. The subjugation of the status of women in the church is enhanced by types such as Ti 'äkono Toeà 'ina (Elder Deacon). Toeà 'ina, meaning elderly man, enlists only males to the status of deacon leader. Traditionally and very much to this day in most denominations, church statuses, particularly the pastoral office, are male dominated. Movements to increase women representation in the Church are evident in this time. Quite extensive in 1906, some church related groups became defunct. New groups, such as 'au sā'ili (youth group), emerge.

The type 'au sā $i l i$, which meant a church service for youths, has been adapted today to mean a service where congregants offer prayer. The specifications for youth, therefore, have been removed. I have mentioned in Section 5.8.4, Samoan understandings of the new type ola fou (Christian beliefs about the afterlife). The type ola e fa 'avavau is an extension of this earlier discussion, where the type has been coined to exemplify an eternal life. Again, these examples demonstrate how the language is aligned with social and ideological transformations, shifts and/or changes.

Fa'aolataga (salvation) is also an interesting type. The type is coined from the foreign type $\mathrm{Fa}$ 'aola, which means Saviour (Jesus). Overall, one of the main points to be made for the RC category in Sulu over time is that its contribution has decreased dramatically and steadily (e.g. 40 types in 1906; 8 types in 1944 and 7 types in 1977).

\subsection{5) Social Culture}

A total of 23 foreign types were identified in the SC category. Types indicate a very important point about language use-influence and adoption of governance terms by the Church. As examples, komiti, a term which emerged in the governance sphere, is used as Komiti 'Au Leoleo 
(Prayer Committee). Leoleo, a police officer, is collocated with malumalu (Leoleo Malumalu) to reference a chapel officer/security. Also, peresetene (president) is used with $\bar{a}$ 'oga (Peresetene $\bar{A} \operatorname{og} a$ ) to reference a theological college principal. Other examples include types fa 'avae and peresetene, which I argue originated from the government words constitution and president, are now being used by the church.

The most frequently used types are Ao 'o le Malo (Head of State-9 tokens) and senate (senate- 5 tokens), both government-related types, emerge in Sulu and not Sāvali. A new type that also emerges is ali 'i suesue (researcher) and su'e tusi (auditor).

With shifts to paid employment, we see for the first time the extension of the type 'aufaigaluega, which is used as a collective noun for pastors, to refer to employees.

The type 'Āvoka, used as the name for the Methodist boarding school for girls, falls under both religious and social culture. The reason I have included it here is the idea of segregation, where schools such as 'Āvoka (Methodists) and Papauta (EFKS) were established as a continuation of missionary initiatives of having schools for young girls to prepare them for religious calling. Types in the SC category have provided evidence of an increase in lexical and semantic extensions.

Of the 23 foreign types, 13 new types are identified. These are:

- ali'isu'esu'e researcher 1 token

- fa'amasinoga court of law 3 tokens

- fa'avae constitution 1 token

- filifili vote 2 tokens

- $f u^{\prime} a$

- lekeono legion

- peresetene president 2 tokens
- pūlega

- ritaea

- sefulua' $i$

- senate

- tamao ‘āiga

- tusitala church district 4 tokens retire/retirement 2 tokens

tithing 2 tokens senate 1 token foreign wealth 7 tokens writer/author 3 tokens

The types are categorised into the areas of education (ali'i su'esu'e, tusitala), national governance (fa'amasinoga, fu'a, senate, lekeono), church governance (fa'avae, filifili, peresetene, pülega, ritaea, sefulua'i) and wealth (tamao'áiga). The types filifili and ritaea require further discussion.

In the Samoan Christian church today, decisions are decided democratically through voting. Even the election of faife 'au are filifili within a congregation and ordained by the mother 
church. The type ritaea is also used by the church to exemplify the retirement of the clergy. Some of these concepts have been adopted from government systems for governance.

\subsection{6) Material World}

A total of 19 foreign types were categorised under MW. This category offers a vast variety of physical types such as 'apamemea (bronze medal), fale laupapa (timber store), fale maliu (mortuary), fale tapua ' $i$ (church building), fu'a (national flag), iunivesitē (university), laulau (table), Maota Maualuga (parliament building), silika (silk), tusi molimau (witness letter), tusi tupe (bank account booklet) and telefoni (telephone). The types above show how Samoa's material culture correlates with national politics, the economy, education, and commerce.

Of the 19 foreign types, 12 are new types and fall under the following sub-categories:

- building:

$\begin{array}{lll}\text { fale laupapa } & \text { timber warehouse } & 1 \text { token } \\ \text { fale maliu } & \text { morgue } & 1 \text { token } \\ \text { fale tapua' } i & \text { church building } & 1 \text { token }\end{array}$

- furniture:

$\begin{array}{ll}\text { laulau } & \text { table } \\ \text { moega } & \text { wooden bed } \\ \text { pulela'a } & \text { church alter }\end{array}$

1 token

(20)

- communication:

niusipepa newspaper

1 token

1 token

tusi molimau

witness letter

1 token

- material

silika

silk

1 token

- personal

tusi tupe

bank account

1 token

uafana

weapon

1 token

1 token

A few types need further discussion. The type pulela ' $a$, for instance, is another type that was borrowed from another Pacific language, in this case Tahiti, to make sense of altar. But there is more to the use of pulela ' $a$. A closer examination of the type reveals that pulela ' $a$, spelt

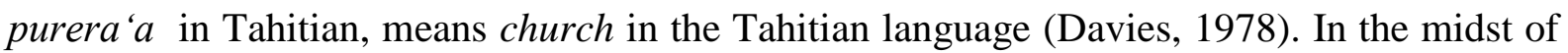
being exposed to new ideologies, the missionaries and Samoan advisors decided not to use pulela' $a$ as the type for church but instead coined the types falesā, malumalu or fale tapua $i$. Like fales $\bar{a}$ and malumalu, fale tapua ' $i$ is collocated from the two existing types of fale (house) and tapua ' $i$ (worship). Note that while Samoans' indigenous religion had been transformed, 
and some pre-Christian words were abolished, some words, such as tapūa 'i, have been preserved.

The invention or introduction of morgues, which resulted in the coining of the type fale maliu, records a change in Samoans' traditional death rituals and practices where the deceased's body was kept with the family and preserved in coconut oil. Laulau, an indigenous word for a flat food server created from coconut leaves, is lexically extended to accommodate a dining table. Overall, these types exhibit how Samoa's material culture correlates with changes to national politics, the economy, education, commerce and way of life.

\subsection{7) Natural Environment}

Only three foreign types were found to fit the NE category. All three are new types, also. These are:

$\begin{array}{lll}\text { - fulūgau } & \text { (flu) } & 1 \text { token } \\ \text { - gata } & \text { (snake) } & 4 \text { tokens } \\ \text { - nātura } & \text { (nature) } & 2 \text { tokens }\end{array}$

The three types identified under the NE are fulu gau (reoccurrence of the the flu- 1 token), gata (snake -4 tokens) and nätura (nature-2 tokens). The types had no connection and were used to address sickness and the use of gata was in a Biblical context. Nätura was used to reference the natural enivornment while saito was used to refer to food preparations and the use of saito as a carbohydrate in Samoan foods. These collocations again reflect the correlation between language and society.

\subsection{8) Other}

There are no foreign types in the OTH category for the Sulu 1977 file.

\subsection{9) Overview of Sulu 1977 findings}


The low number of foreign types since 1906 has led to a decrease of new words introduced into the gagana. This may be a result of the influence of governance related types as an increasing amount of these words are being adopted and used by the Church.

Overall, of the 120 foreign types identified in Sulu 1977, a total of 79 new types were found. Thinking of these in another vein, the low number of foreign types since 1906 has led to a decrease of new words introduced into the gagana. This may be a result of the influence of central governance related types on religious types as an increasing amount of these words are being adopted and used by the Church. What this also indicates is either the stabilising or replacing of religious discourse.

\subsection{1) SĀVALI 2014 FILES:}

Table 17 presents a categorical break-down of foreign types for the file.

Table 17:

Categories/Types/Tokens: Sāvali 2014

\begin{tabular}{|c|c|c|c|c|}
\hline \multicolumn{5}{|c|}{ Sāvali 2014} \\
\hline Categories & Types & $\%$ & Tokens & $\%$ \\
\hline 1. Place Names & 17 & 3 & 62 & 3 \\
\hline 2. Proper Nouns & 27 & 6 & 160 & 7 \\
\hline 3. Religious Culture & 36 & 8 & 155 & 6 \\
\hline 4. Social Culture & 269 & 58 & 1582 & 65 \\
\hline 5. Material World & 98 & 21 & 356 & 15 \\
\hline 6. Natural Environment & 19 & 4 & 99 & 4 \\
\hline 7. Other & 0 & 0 & 0 & 0 \\
\hline Total & 466 & 100 & 2414 & 100 \\
\hline
\end{tabular}

\subsection{1) Table 17 Analysis}

The ascendancy of SC is striking for both types (269 types-58\%) and tokens (1582-60\%). MW is a distant second attributing a respectable $21 \%$ (98) and $15 \%$ (356) of types and tokens, respectively. The sum of foreign types and tokens for the remaining categories all fall below 
10\%. What could be made of this imbalance? Sections 5.11.2-5.11.8 provide an in-depth analysis of these trends.

\subsection{2) Place Names}

The most frequently used PLN is 'Amerika Sāmoa (American Sāmoa) with 18 tokens. Atu Kuki (Cook Islands - 4 tokens), another Pacific nation, is also used. 'Aukilani (Auckland) and Ueligitone (Wellington) are mentioned in the file, not surprisingly with both cities being a stronghold for Samoan communities. Another city with a stronghold of Samoans is Kuiniselani (Queensland), which is mentioned six times.

Samoa's political relations with 'Ausetalia (Australia-12 tokens), Saina (China-10 tokens) and Iâpani (Japan-6 tokens) are represented in PLNs, also. The most common diplomatic relation was aid more than anything.

The Middle Eastern city of Nasareta (Nazareth - 2 tokens) is mentioned. It is collocated to refer to 'Ekālesia Nasareta (Samoan Nazareth Church). In the past two decades, the rise of newly formed Samoan sects such as 'Ekālesia Nasareta, particularly overseas, has expanded Samoan church denominations.

Other PLNs mentioned which have not been mentioned in previous indicator years are Asia (Asia-2 tokens), Osenia (Oceania-1 token), Filipino (Phillipines-1 token) and 'Itālia (Italy-1 token). These types are primarily collocated under governance discussions.

Of the 17 foreign types found, 7 are new types. In alphabetical order, the seven new PLNs are:

- Atu Kuki Cook Islands 1 token

- KuiniselaniQueensland 1 token

- Osenia Oceania 1 token

- Polenisia Polynesia 1 token
- Sineva Geneva 1 token

- Uelegitone Wellington 1 token

- Itālia Italy 1 token

The frequency for each type was one token. Similar to the use of the types Uelegitone and Kuiniselani, it was mentioned in Section 5.10.2 (Sulu 1977) about the emergence of the types 'Aukilani (Auckland) and Kalaisetete (Christchurch) in collocations to do with the increasing numbers of the Samoan population moving to live in New Zealand. 
Atu Kuki is an interesting type. Unlike Fiti (Fiji), Kalaigolo (PNG), Kilipati (Kiribati), Niu Kāletōnia (New Caledonia), Lifu (Lifou Island), Niuē (Niue), Niu Sila (New Zealand), Havai 'i (Hawai i) and Niu Kini (New Guinea) mentioned in Sāvali 1906, the type Atu Kuki is coined with an existing word (Atu) and a loanword (Kuki).

The collocation of the types 'Osenia, Sineva and 'Itālia are primarily used in central governance discussions.

\subsection{3) Proper Nouns}

Of the 27 foreign types under the PN category, only the type Matâgaluega (government division-153 tokens) was used in a previous indicator year (Sāvali 1944). The remaining 26 types are all new words.

The types 'Agelikana (Anglican—1 token) and 'Akiepikiopo (Archbishop - 6 tokens) are used to reference denominational distinctions. Samoans' reverence towards the Christian God is reflected, as in previous indicator years, through a continued addition of types such as Tapa 'au Sili ' $i$ le lagi (Highest Chief in Heaven-4 tokens). Interestingly, the 1906 type Ieova (Jehovah), seems to have fallen out of favour by the CCCS.

One of the striking observations of foreign types in Sāvali 2014 is the variety and extent of phrase type words. Consider, for instance, the following foreign types:

- Matāgaluega 'o Falepuipui ma 'Au'aunaga 'o Amioga Toe Fuata 'ina (Prisons and Corrections Services)

- Matāgaluega 'o Puna'oa Fa'alenatura ma le Si 'osi'omaga (Ministry of Natural Resources and Environment)

- Matāgaluega 'o Tinā ma Tama 'ita 'i Afio 'aga ma Agafeso 'ota $i$ (Ministry of Women, Community and Social Development)

- Komiti 'o 'Ele 'ele (Land Board)

- 'Au'aunaga Fa'a-Soifua Malōlōina (Health Department)

- Fa'amasinoga 'o Talosaga (Court of Appeal)

- Fa'amasinoga 'o Ulua 'i Su'esu'ega (Coroners Court)

The increase of these kinds of foreign words indicate a shift in how words are coined to accommodate foreign meanings. In all the above types, the combination of existing and 
loanwords is prominent. The ascendancy of these kinds of foreign types also points to the increase in central government roles and influence.

Other government related proper nouns are Sui 'o le Fono 'o Sui Tōfia (Council of Deputies3 tokens) and Ao Mamalu 'o le Mālō (5 tokens). Though new types, both have connections to Samoa's paramount kinship titles based on the belief that holders of these in central government top leadership positions should have strong connections to the bloodlines of Samoan aristocracy.

Samoan denominations such as Samoan Assembly of $\operatorname{God}^{27}$ (AOG) (4 tokens) and 'Ekālesia Aso Fitu (Seventh Day Adventist-3 tokens) are also mentioned. As stated earlier, Samoa's sect expansion has resulted in an increase in foreign types associated with denominations. Other types include 'Agelikana (Anglican-1 token) and 'Akiepikiopō (Archbishop-6 tokens), which are used to reference denominational distinctions. Samoans' reverence towards the Christian God is reflected, as in previous indicator years, through a continued addition of types such as Tapa'au Sili 'i le lagi (Highest Chief in Heaven-4 tokens). Interestingly, the 1906 type Ieova (Jehovah), which was also present in 1944 and 1977, seems to have fallen out of favour by the CCCS or at least out of print in 2014.

The appearance of the type Heta (Cyclone Heta-1 token) in the file is collocated as a reference to cyclone Heta which hit Sāmoa in 2004.

Finally, and somewhat surprising, is the low representation of people names in the file. The only person names that appear are 'Eveni (Evan-1 token), Susi (Suzy-5 tokens), Solomona (Solomon-4 tokens), Mōlesi (Morris-1 token), 'Eva (Eve-1 token), 'Atamu (Adam-1 token) and 'Apineru (Abner-1 token). Apart from Mōlesi and 'Eveni, all people name types are Biblically related. The low representation of people names in Sāvali 2014 is connected to the decrease in Land and Title mentions in the paper, which was a prominent feature in the 1944 and 1977 publications. The 2014 issues, for instance, has become more focussed on national and global developments.

\subsection{4) Religious Culture}

\footnotetext{
${ }^{27}$ The AOG denomination is not considered a mainstream church because of its much later arrival to Sāmoa. The three mainstream churches are the Congregational, Methodist and Catholic denominations.
} 
For the RC category, 36 foreign types were found. The ninth most frequently used type within the entire Sāvali 2014 file, 'ekālesia, which can refer to both congregation and denomination, tops the type frequency for RC category with 104 tokens. I have included 'ekâlesia here because its meaning has shifted from referring to only a denomination in Sāmoa, to be inclusive and reflect the Church as a global religion.

Church operations, of course, are functionalised by human resources which relates to the second most frequently used type being 'aufaigaluega. The type 'aufaigaluega (23 tokens) is used to refer to both the ecclesiastical (pastors and lay preachers) and non-ecclesiastical offices (deacons and youth), which is also a shift in semantics where it was used to refer to the pastoral office only.

Of the 36 foreign types, 13 are new types. The most frequently used of these new types is the word fa'amägalo (forgiveness-20 tokens). This is followed by ola fa'apa iaina (Christian life -10 tokens), fa 'afeagaiga (pastor —8 tokens), misiona (mission-5 tokens), 'akiepekopō (archibishop -3 tokens), vala 'auina (calling -3 tokens) and types such as anapogi (fasting), $\bar{a}$ 'oga aso Sā (Sunday School), fa 'asalaga tūma 'oti (religious punishment), perofeta (prophet), suafa pa ia (Holy Name), failāuga (lay preacher) and vala'au pa ia (death) each with one token.

The type fa 'amägalo was used mainly as a reminder to Samoan Christians of the importance of the practice of forgiveness to their spirituality. This was aligned with collocations of the type ola fa'apa iaina.

The type fa 'afeagaiga is an interesting one. Lexically, the type is comprised of the causative prefix $f a$ ' $a$ and an indigenous word feagaiga, which means a social covenant. Originally, the type applied to the pastor of the Congregational denomination only, based on the fact that only the Congregational pastor is called to ministry as the covenanted one. That is, upon his arrival, a covenant is formalised through the reciprocating of two ie toga (fine mats) between the pastor and the congregation in the ceremony called osig $\bar{a}$ feagaiga (religious ritual of initiation). These fine mats are kept until the covenant is deemed void either through removal or death of the pastor. However, the type in the 2014 files is used to refer to non-Congregational pastors such, particularly the Methodist and Catholic clergy.

The type failāuga is used to refer to lay preachers of the Methodist denomination. As a Methodist specific term, then, this further underlines the existence of denominational specific types. The use of the type misiona indicates the continuation of Congregational missionisation 
in the Pacific. Every year, for instance, Congregational pastors are sent on missions, some lasting three years. In fact, another form of missionary activity is the temporary posting of Church graduates to newly established congregations who are in need of a pastor, but do not have the capacity to pay for his wages. For a missionary pastor, the Congregational church funds the pastor's wages for three years.

The type suafa pa 'ia has undergone a lexical expansion where in Sulu 1944 (Section 5.8.4), it was collocated as only suafa, which refers to the Christian deity. This further enhances the point about Samoans' respect for the Christian deity and adds to the extensive lexical collocations mentioned in Section 5.7.3 where the types Atua (God), Tamā (Father), Tamā aoao (Godly Father), Тири (King), Tири Moni (The true King), Tupu 'o Tupu (King of Kings) and Tamā 'o 'i le lagi (Father in Heaven) are also used for the Christian deity.

The sum of types and tokens for RC in this file has increased when compared to Sāvali 1977 file where the RC category accounted for only $2 \%$ and $4 \%$ of total types and tokens respectively. This increase is perhaps a result of the increase of Samoan non-mainstream denominations and the subsiding of the social and political modernisation developments of 1977, which was a period where independence transitioning was in full gear.

\subsection{5) Social Culture}

The ascendancy of the SC category is attributed to the finding that five types are positioned in the top ten most frequently used words. By order of ranking, these are:

Type

1. $m \bar{a} l \bar{o}$

2. tupe

3. 'ofisa

4. matāgaluega (ministry)

5. Atua

6. A'oa'oga

7. Minisitā

8. atina'e

9. 'ekālesia

10. 'oloa (government)

(money)

(office)

(Christian God)

(formal education)

(government minister)

(government projects)

(congregation)

(foreign goods)

\section{$\underline{\text { Category } \quad \underline{\text { Tokens }}}$}

SC

MW

178

MW

156

SC

153

PN

119

SC

116

$\mathrm{SC}$

109

SC

104

RC

104

MW 
It was stated in Section 5.9.5 of the increase of vocabularies to accommodate Samoa's changing social environment, particularly regarding the nation's obligations to local governance and international relations. In 2014, evidence suggests that foreign types for SC have intensified. Consider, for instance, in alphabetical order the following types:

\section{$\underline{\text { Ministries-Local Bodies-Services }}$}

- 'Au'aunaga fa'a-soifua mālōlöina:

- 'Au 'aunaga fa 'avā' 'aitau:

- 'Au 'aunaga mo le soifua mālōlōina:

- 'Au'aunaga tau 'aitālafu ma tusi saisai:

- 'Au'aunaga tau fa 'amasinoga fanua ma suafa:

- 'Ele 'ele, fuagāfanua ma le si 'osi 'omaga:

- Fa'alāpotopotoga 'o 'ele 'ele a sāmoa:

- Fa'alāpotopotoga ma pūlega:

- Fa'alāpotopotoga mō le mālosi 'aga Fa'aeletise:

- Fa'alāpotopotoga 'o leipa a le lalolagi:

- Fa'alāpotopotoga 'o mavaega tausi a sāmoa:

- Fa'alāpotopotoga 'o su'esu'ega fa 'asaieneisi:

- Fa'alāpotopotoga va'a 'o sāmoa:

- Fa'alāpotopotoga fa 'atūma 'oti a le mālō:

- Fa'amasinoga maualuga:

- Fa'amasinoga 'o talosaga:

- Faigà aloa 'ia e totogi ai tupe a le atunu 'u:

- Faigā fa 'apisinisi:

- Faigã fa'avae
Health Department

Meteorological Service

National Health Service

Fees for the Warrants and Bailiff services

Fees for the Lands and Titles

Court services

Lands, Survey and Environment

Samoan Land Corporation (SLC)

Secretariat Board

Electric Power Corporation

(EPC)

International Labour

Organisation

Unit Trust of sāmoa

Scientific Research Organisation of Sāmoa

Sāmoa Shipping Corporation

Limited

Government Sector

Supreme Court

Court of Appeal

National Payment System

E-Commerce

Policies 
- Faigā pālota:

- Faitūlāfono:

- Feagaiga fa' 'avā- 'o-mālō:

- Fefa 'ataua 'iga, mea tau pisinisi ma atina'e 'o alamanuia:
Election

Clerk

International Treaty

Trade, Commerce and Industry

The above types signify two important points. Firstly is the variety of collocated indigenous and introduced types. Secondly is the use of indigenous words in the formation of new types. Types such as feagaiga, which generally means a social covenant in indigenous contexts, is semantically extended to mean international treaty. Other types include fa 'avae (foundation) which is used to mean policy and Màlō Aufa'atasi which means Commonwealth federation. The use of the indigenous word gasegase to mean outpatient is another example. A full range of types can be viewed in Appendix 1.

Types such as poloketi (project), poto salalau (Western education), peimeni (payment), penisiona (pension), pāsese (transport fare), paaga (business partnership), ofo (offer), ofo (bid), tiute (customs duty), mita (electricity meter), konesula (consular), kiliva (delivery), kilia (customs clearance), konekarate (contract), faitauga (legislation reading) and lisi (lease) are only a few of many foreign types integrated in 2014.

Overall, the sub-categories that emerged for SC in 1977, such as tribunal, governance, occupation, monetary and education, are also the same sub-categories in 2014. This time, however, the increase in foreign types under these sub-categories has been considerable over time.

Of the 269 foreign types found in SC category, 181 are new types. These are categorised into the following domains:

- government

- government services

- communication fono fa'apalemene (caucus)

'o le suāvai 'ia 'aua ne 'i 'uti'uti 'ae fa'apea le fa'atamala i le suāvai lafoa'i, 'o taumafai mo tagata 'uma 'aemaise le fa'alāpisi solo ma ona a'afiaga (water and sanitation, food security and waste management)

ala leo (radio frequency) 
- infrastructure

- land

- housing

- tourism

- $\quad$ social status

- trade and exchange

- business/entrepreneurship

- health

- commerce

- education

- law and policy atina'e tetele (infrastructure)

fua fanua (surveyor)

fa' 'atau tu' $i \quad$ (mortgage sale) $^{\prime}$

mata 'aga (natural attractions)

minisitā 'o le kapeneta (minister of cabinet)

'oka (goods order)

pisinisi 'umia sa'oloto (private businesses)

tagata gasegase (outpatient)

lāfoga

$(\operatorname{tax})$

tikerī

(degree)

tùlāfono 'o teuteuga

'o le fa'avae (constitution amendment act)

- employment

konekarate

(contract)

- transport

laisene

(driver's license)

- socialisation

fā'aili

(music band)

As is obvious from the type domains, foreign types in the SC are vast. Government types are mainly government roles such as sui fofoga fetalai (deputy speaker), resitara (court registrar), inisetiute 'o fa' 'atonu (institute of directors), su'e tusi (government auditor) and nofoaga 'autū teu-fa'amatalaga (national data centre). Government service types ranged from research projects, such as su'esu'ega 'i le la 'asaga mai 'i le olaga a'oa'oina aga 'i 'i le olaga faigaluega (school to work transition survey) to government sub-committees such as vaega o le si 'osi 'omaga ma mālosi 'aga fou mai mālosi 'aga fa' 'afouina (committee for environment and renewable energy).

For communication, there are a number of types. These include ala leitiō (radio frequency), 'imeli (email), 'initaneti ${ }^{28}$ (internet), upega tafā 'ilagi (World Wide Web), tusitusiga (writings) and feso'ota 'iga ma fa'amatalaga televave fa'aneionapō (communications and information technology).

Types to do with infrastructure include atiina'e (government development projects) and fefa 'ataua 'iga, mea tau pisinisi ma atiina 'e 'ae 'o alamanuia (trade, commerce and industry).

\footnotetext{
28 Initaneti here is spelled initeneti elsewhere in the corpus. This indicates a couple of things: (1) human error/typing and (2) author's spelling preference.
} 
Types such as fua fanua (land surveyor), pule o vaega 'o fanua (unit titles), 'ele 'ele, fuagafanua ma le si 'osi' 'omaga (lands, survey and environment), tau (land valuation), tau (rates) and teuina 'o lā 'au ma fanua (landscaping) are types to do with land. Other types, which are categorised under housing but have implications on land, are types such as fa' atau tu' $i$ (mortgage sale), poloka (land block), fa'alāpotopotoga 'o 'ele 'ele a Sāmoa (Sāmoa Land Corporation) and komiti 'o 'ele'ele (land board).

Tourism types are an interesting new development. These types have been created as Sāmoa has prioritised its tourism industry as a key economic revenue source. Types include Fetufa 'iga o atiina 'e tau tagata tafafao mai fafo (Sāmoa tourism exchange), mata 'aga (attractions), tagata tafafao mai fafo (tourists) and türisi (tourist). Note how the English type tourist has two variations in Samoan.

Social status types are all government related. These include sui ta ita ifono (deputy chair), pule fa'atonu (regulator/director), laulaufono (board), konesula (consular), 'amapasa (ambassador) and 'asosi (association). Trade and exchange types include kamupani fa 'avā 'o $m \bar{a} l \bar{o}$ (international partners) and lāfoga tāofi (withholding tax).

Business and entrepreneurship types were prominent. These include pisinisi e lafo ai tupe (money transfer operators), pisinisi tuma'oti (private sector) and pisinisi 'umia sa'oloto (private businesses). The only health related type was gasegase (outpatient).

Commerce types were mainly used regarding taxes. These include lāfoga tāofi (withholding tax), 'ofisa 'o lāfoga (tax office), lāfoga fa' 'aui (sales tax), tupe tāofi (retention fee), totogi (fee), tupe teu fa' 'afaigaluega (investment) and fa 'aititiga 'o le aogā (depreciation). The development and significance of commerce on the maintenance and viability of the modern central Samoan government is obvious in these foreign type examples.

Education types include tusitusiga (publication), sikolasipi (scholarship), puleā'oga (school principal), poto salalau (western education/knowledge) and fa ' $a u^{\prime} u$ (graduation). These types indicate the rapid development of the Samoan modern centralised education system to accommodate both local and international opportunities.

Law and policy foreign types were also numerous. Some types found were talosaga mo tusi 'o samania mo fa 'ai 'uga (judgement summons), mavaega tausi (trusts act), poloā'iga lè tūmau (interim order), poloā'iga aoao 'o tau 'o 'oloa (general price order) and tūlāfono (trustee act). 
These types were collocated to highlight the importance of introduced Western law and order models by central government.

Employment related types included inisinia (engineer), kiliva (goods deliverer) and kilia (customs clearance officer). Transport and socialisation types were few, but nonetheless significant in the overall make-up of foreign types in the SC category. Types include kilomita (kilometre), peti (bet), and tāpolo (golfer).

Compared to 1906, 1944 and 1977, foreign types in Sāvali 2014 suggest an increased intensity of the integration and influence of foreign types. This signifies two important points. Firstly, is the variety of collocated indigenous and introduced types now present. Secondly is the use of indigenous words in the formation of new types.

Overall, the high and varied amount of types in the SC category illustrates a nation immersed in international consumerism and law and order regimes.

\subsection{6) Material World}

There are more MW types in Sāvali 2014 than in any other file examined. With $21 \%$ (98) and $15 \%$ (356) of types and tokens, foreign types in the MW category have heightened in 2014, more than any other indicator year.

The most frequently used type is tupe (money) with 178 tokens. Tupe is ranked second in the overall token calculations for the file. 'O $\overline{f i s a}$ (office) is third overall with a total of 156 types. Other frequently used types are as follows:

- 'oloa

- $\quad$ tusi

- 'auala

- 'eletise

- ta'avale (foreign goods)

(book)

(government road)

(electricity)

(car)
103 tokens

91 tokens

62 tokens

45 tokens

24 tokens

Contact with foreign countries through trade and commerce processes are serviced by types such as uafu (wharf-5 tokens), 'oloa (foreign goods-103 tokens), 'oloa 'auina atu 'i fafo (exports), faletupe (bank-18 tokens), faletupe a le Lalolagi (World Bank-1 token), faletupe 
o fefa 'ataua 'iga (commercial bank-4 tokens) and faletupe 'o atina'e (development bank-3 tokens) and faleoloa (goods shop-1 token).

Improvements in the education sector and the upskilling of people are manifested through types such as tikerī (university degree-1 token) and iunivesitē (3 tokens). The establishment of the National University of Sāmoa (NUS) in 1983 provided an avenue for the development of the local population. Relations with New Zealand have provided further opportunities for this development with many NUS students engaged in post-graduate research, particularly at Victoria University of Wellington (VUW).

Only a handful of transport related types emerge. These are va'alele (aircraft- 6 tokens), ta'avale (car-24 tokens), pasi (bus-4 tokens), malae va'alele (airport-1 token), loli (lorry-12 tokens), afi (engine-12 tokens), kiso (diesel), penisini (petrol), tā (tar-8 tokens) and 'auala (government road-62 tokens). These types reflect Samoa's trade and transport infrastructure.

Indicating an awareness of health and safety is portrayed in types such as lapisi (rubbish), laisene ta 'avale (car license), laisene 'avamalosi (liquor license), fualā 'au fa 'asāina (drugs), kasa (gas emission), lifi (elevator), sikareti (cigarette), tōtini (socks), tulinamu (mosquito coil), vailā'au (chemicals-1 token), falema'i (hospital-19 tokens), maota gasegase (hospital-1 token), 'ave (hospital ward-1 token), fale 'aiga (restaurant-2 tokens), fale tineimu (fire department), fale koluse mūmū (Red Cross house), fale maliu (morgue-1 token), 'ea mālūlù (air conditioner-7 tokens), fagu fuimu (fire extinguisher-1 token) and falepuipui (prison10 tokens).

Housing and accommodation infrastructures, however, are required and are evident in types such as potu (room-1 token), nofoaga tūtotonu (conference centre-2 tokens), faletalimālō (hotel/motel -3 tokens) and fale nofotumau (hostel-1 token). Foodstuffs such as susu (milk2 tokens), suka (sugar-1 token), sanuisi (sandwich-3 tokens), saimini (noodles-3 tokens) and pata (butter), for instance, were obviously very important for hospitality purposes.

Nationalism and identity are represented in types such as tagāvai (national flag-2 tokens), pepa fānau (birth certificate-1 token), tusi folau (passport-1 token) and laisene (license - 5 tokens). Playing an influential role in nationalism and identity is 'sport'. Sport related types also emerge such as pine 'apa (bronze medal-1 token), pine 'auro (gold medal -4 tokens), pine siliva (silver medal-1 token), fale a' au (national swimming centre-1 token), fale ta 'alo 
(sports stadium-8 tokens), malae tāpolo (golf course-6 tokens) and malaeta'alo (sport field -8 tokens).

The infrastructures needed for local and international relations, at least in Samoa's case, have resulted in the development and use of new types.

Of the 98 foreign types, 76 are new types. Most are categorised under areas such as building, food, music, technology, sports, personal and clothing. Building is the most extensive with types such as:

- fale a'au

- fale faigaluega

- fale gaosi 'oloa

- fale koluse mūmū

- fale nofotūmau

- fale ta'alo

- fale 'aiga

- falefeso 'ota' $i$

- falepuipui

- faletineimū

- maota gasegase

- maota tapuã $i$

- 'ófisa 'autū swimming complex

workplace

good manufacturer

red cross office

hostel

sports stadium

restaurant

communications building

prison

fire service

hospital

church building

main office

These types are extensions to fale laupapa (timber warehouse), fale maliu (morgue) and fale tapuā' $i$ (church building) identified in Sulu 1977. Note how another new type for church building is coined (maota tapua ' $i$, see Section 5.10.6). Another significant point is the coining of the word maota gasegase for hospital. One of the common types for hospital is falema' $i$. But because a person's sickness, particularly that of high chiefs and orators, requires use of respectful terms, the seeming replacement of falema' $i$ with maota gasegase suggests the acknowledging of Samoan culture in lexical coinages. But perhaps the most striking observation in trends here is the dominance of government related buildings.

Food related types include araisa (rice), lialia (vermicelli), pata (butter), pīsupo (corned beef), saimini (noodles), sanuisi (sandwich), sikareti (cigarette), 'ava mālosi (alcohol) and susu 
(milk). These types were mainly collocated with notices to do with hospitality. The only other food related type was 'oloa 'auina atu'i fafo (goods exports).

There are three types to do with music. These are kitara (guitar), pīano (piano), and pu (trumpet). Technology related types identified appeared in the forms of faipa (cable fibre), komepiuta (computer), kopi (photocopy) and masini e alu 'i le lā (solar system).

Sports related types came in the form of malae ta 'alo (sports complex), malae tâpolo (golf course) and pine (sports medal). Samoa's increased involvement in regional and international sport has initiated a dramatic overhaul of its sporting complexes.

Other important types include tusi faufautua (management letter), tusi folau (passport), tusi saisai (warrant), tusiofo (letter of tender) and pepa fānau (birth certificate). These types were categorised as personal documents and indicates the correlations between bureaucratization and texts.

Clothing types were minimal and are represented by the types lipine (ribbon), mata tioata (glasses), mitiafu (t-shirt), taga (pocket) and tōtini (sock). Note that the type tōtini is a loanword from the Tahitian language.

An overall survey of the types indicate that types in MW are reflective of Samoa's significant calendar events for 2014 and beyond. For instance, 2014 was an important year for Sāmoa as the nation was hosting the Third International Conference on Small Islands Developing States (SIDS Conference). Sports, roads and accommodation infrastructure built for the SIDS Conference was planned to be of subsequent use for the All Blacks first ever test in Apia in 2015 and Samoa's confirmed hosting of the South Pacific Games (SPG) in 2017. These developments reflected Samoa's local and international commitment to international relations.

The development of government sectors and services, for instance, has also increased operational types such as tusi saisai (warrant), tusi tauofo (proposal letter) and tusi folau (passport). Contact with foreign countries through trade and commerce processes are serviced by types such as uafu (wharf-5 tokens), and 'oloa 'auina atu 'i fafo (exports). The infrastructures needed for local and international relations, at least in Samoa's case, have resulted in the development and use of new types.

\subsection{7) Natural Environment}


Nineteen types categorised under NE were identified. Of the nineteen, the type lalolagi (earth-38 tokens), suāu' 'u ${ }^{29}$ (oil-12 tokens) and 'eka (acre-11 tokens) were the most frequent. Types such as sunami (tsunami-3 tokens) and suiga o le tau (climate change-2 tokens) are also used.

The natural environment was also represented by types to do with food and animals. Some examples include pateta (potato-1 token), aniani (onion-1 token), māsima (salt-1 token) and $p \bar{l} p \bar{\imath}$ (turkey-1 token). These types are used in collocations to do with the tourism and hospitality sectors.

A crackdown on drug abuse and animal custody at the time of imminent high visitor numbers to Sāmoa are reflected in the types ta ifau (dog-8 tokens) and maruana (marijuana-1 token). For instance, the phrase tapu 'eina 'o ta 'ifau ta'alo (seizing of unregistered dogs) and 'Öfisa e puleaina ta 'ifau (Samoa's Dog Management Unit) provide a backdrop into the monitoring initiative.

Of the nineteen identified as foreign types, nine types were newly introduced words. These are:

- $\quad$ atumotu lāiti

- ‘àvoka

- 'ea mālūlū

- kasa

- maruana

- nofoaga fa'asao

- $p \bar{\imath} p \bar{\imath}$

- puna'oa fa'alenatura

- sūnami

$\begin{array}{ll}\text { small nation states } & 1 \text { token } \\ \text { avocado } & 1 \text { token } \\ \text { cold air } & 7 \text { tokens } \\ \text { gas } & 6 \text { tokens } \\ \text { marijuana } & 1 \text { token } \\ \text { natural reservoir } & 1 \text { token } \\ \text { turkey } & 1 \text { token } \\ \text { natural resources } & 26 \text { tokens } \\ \text { tsunami } & 3 \text { tokens }\end{array}$

Like the trends regarding Samoa's involvement in local, regional and international affairs, types to do with the natural environment indicate Samoa's intentions for environmental preservation (puna 'oa fa 'alenatura and nofoaga fa 'asao), regional politics (atumotu läiti), the production of local produce and healthy eating ('āvoka), fight against drugs (maruana) and accommodation requirements for hotels ('ea mâlu $l \bar{u})$. The collocation of the type kasa referenced the use gas ovens in the hospitality industry. The type $p \bar{p} \bar{\imath}$ was used as the Samoan

\footnotetext{
${ }^{29} \operatorname{Suāu'} u$, meaning oil, is identified as foreign here based on the new meaning ascribed to refer to crude oil, as opposed to coconut oil ( $\left.u^{\prime} u\right)$.
} 
government policed the importation of unhealthy foods, such as turkey wings. Lastly, the type sūnami was used in text as discussions about natural disaster defences continues to be a government agenda.

\subsection{8) Other}

There are no foreign types identified in the OTH category in Sāvali 2014.

\subsection{9) Overview of Sāvali 2014 findings}

Of the 466 foreign types identified in Sāvali 2014, 358 new types emerged. To interpret, from 1906 to 2014 Sāmoa underwent a busy period of social change. Sāmoa was ambitious, and successful, in her development initiatives. By 2014 she was playing host to a significant international event in her and the region's political calendar. The outcome of all this has been the extensive influx of foreign types into the Samoan vernacular.

\subsection{2) SULU 2014 FILES:}

Table 18 presents a categorical break-down of foreign types for the file.

Table 18:

Categories/Types/Tokens: Sulu 2014

\begin{tabular}{|c|c|c|c|c|}
\hline \multicolumn{5}{|c|}{ Sulu 2014} \\
\hline Categories & Types & $\%$ & Tokens & $\%$ \\
\hline - $\quad$ Place Names & 40 & 13 & 187 & 10 \\
\hline - $\quad$ Proper Nouns & 81 & 26 & 295 & 17 \\
\hline - Religious Culture & 30 & 10 & 301 & 17 \\
\hline - Social Culture & 89 & 28 & 734 & 41 \\
\hline - Material World & 58 & 19 & 189 & 11 \\
\hline - Natural Environment & 11 & 3 & 45 & 3 \\
\hline - Other & 2 & 1 & 4 & 1 \\
\hline Total & 311 & 100 & 1755 & 100 \\
\hline
\end{tabular}




\subsection{1) Table 18 Analysis}

The total foreign types (311) in Sulu 2014 accounts for 32\% of the total foreign types in all Sulu texts while accounting for $16 \%$ of the overall foreign types for all texts (Sulu and Sāvali texts combined). To put these statistics in perspective, however, when compared with the foreign type numbers identified in Sāvali 2014 (466 types), which accounts for $48 \%$ of the total foreign types in all Sāvali texts and a respectable $24 \%$ of the overall foreign types for all texts, foreign types in Sulu 2014 are relatively low in the total picture, but have increased dramatically compared to the foreign types total in Sulu files for 1944 and 1977.

An immediate analysis of Table 18 shows the clustering of foreign types in the PN (83 types), SC (49 types) and MW (31 types) categories. Quite surprising is the low number of foreign types in the RC category. When compared to Sulu 1977, the foreign type numbers under PN, SC and MW categories have more than doubled, while the foreign types total for the PLN, RC, $\mathrm{NE}$ and OTH categories are relatively identical. An in-depth analysis of each category is provided in Sections 5.12.2-5.12.9.

\subsection{2) Place Names}

Where PLN in Sāvali 2014 were predominantly collocated to Samoa's increased involvement in local, regional and international politics, PLN in Sulu 2014 are primarily Biblically based. The PLNs 'Aikupito (Egypt) and Iuta (Judah) are the most frequently used types each with 32 tokens. Biblical PLNs such as Papelonia (Babylon-17 tokens), Siona (Zion-15 tokens), Kisona (Kishon-12 tokens) and Kalevārio (Calvary_-7 tokens) are also mentioned. What this means is that Biblical place names remain a dominant sub-category in religious discourse.

Samoa's diasporic connections with New Zealand is shown in the types Manukau (ManukauAuckland - 4 tokens) and Niutone (Newtown-Wellington - 2 tokens). Types associated with diaspora are not surprising. This is because the church context is a medium whereby connections to homeland are maintained by Samoans living abroad. It is through the same vehicle that connections are maintained with relatives and friends overseas by those living in Sāmoa.

Regionally, only two Pacific PLNs appear. These are Fiti (Fiji-4 tokens) and Hawai ' $i$ (2 tokens). Although the Pacific is regarded as a realm of religious nations, the decrease in Pacific PLNs perhaps indicates a growing disconnection between Samoans and their neighbouring 
island nations regarding religious aspects, an aspect which was quite prominent in earlier Sulu issues. The offset is a growing connection to metropolitan centres where many Samoans now live. This shift is a reflection of Samoans' changed social interactions based on

Of the 40 foreign PLNs, seventeen were identified as new types:

- 'Asuria Syria

16 tokens

- Ketesemane Gethesemane

- Kolose Colose

- Latokaia Laodicea

- Linikone Lincoln

- Manukau Manukau

- Melepone Melbourne

- Naila Nile

\section{1 token}

43 tokens

1 token

4 tokens

4 tokens

1 token

1 token $\bullet$

- Panapa

- Papelonia

- Peresia

- Perū

- $\quad$ Suria

- $\quad$ Uasigitone Washington

- Kalevārio Calvary

- Kanana Canan
2 tokens

2 tokens

17 tokens

3 tokens

2 tokens

8 tokens

1 token

7 tokens

10 tokens

The most frequently used type, with 43 tokens, is Kolose. Collocations for Kolose were mainly to do with Biblical stories in the Colossians bible chapter. Apart from the types Linikone, Manukau, Melepone and Kalefonia and Uasigitone, all other types were used as Biblical references.

The type Linikone was used to refer to a PLN in America. The same is applied for Kalefonia. The type Manukau was used to refer to the Manukau Samoan congregation in Auckland. The type Melepone was collocated to refer to a church event to be held in Melbourne in 2014. The type Kanana, with 10 tokens, referred to KFTS in American Sāmoa. The Kanana Fou Theological School broke away from Samoan Congregationalism in Independent Sāmoa in 1983 and has become the CCCAS.

PLN foreign types in Sulu 2014 show a tendency for foreign types in this category to be aligned with biblical narratives, something very similar in Sulu 1977 (see Section 5.10.2), where types such as Kisona, Petānia and Tesālonia.

\subsection{3) Proper Nouns}

A total of 81 foreign types under the PN category were identified in Sulu 2014. Categorised under various sub-categories, the highest frequency people name is Tāvita (24 tokens). The 
most mentioned Bible book is Isaia (Isaiah-119 tokens). Regarding denominations, the type Kolisi Faa'faife'au Pāsefika (Pacific Theological College-PTC) is mentioned. PTC has become a higher education pathway for theological students.

One of the most striking observations made for proper nouns in Sāvali 2014 was the high numbers of foreign types to do with government and its ministries and divisions. In Sulu 2014, however, the majority of PN types are mainly the names of deity and people.

The most frequently used types are 'Apisaloma (Absalom) and 'Elisaia (Elisha), each with 11 tokens. Both types were based on bible stories about both characters. While the majority of types were people names, two deity names really stand out. These are Ao and Pule. Ao and Pule, both indigenous words, are used to refer to the Christian deity. These types further enhance the comprehensive list of types to refer to the Christian deity.

Of the 81 foreign types, 11 new types emerged. These are:

- Aso Sā'o Tamaiti

- 'Emanuelu

- 'Eteveni

- Hitilā

- Karolaine

- Leni

- Lotu Tamaiti

- Moselemu

- 'Omeka

- Pãala

- Tautua Party
White Sunday

Emmanuel

Advent

Hilter

Caroline

Lent

White Sunday

Muslim

Omega

Satan

Political party
1 token

5 tokens

1 token

1 token

1 token

1 token

5 tokens

4 tokens

1 token

3 tokens

1 token

I will point out some significant points about the above types. Two foreign type coinages have been constructed for White Sunday, these are Lotu Tamaiti and Aso Sá 'o Tamaiti. The use of the Catholic terms 'Eteveni and Leni are also interesting in the normally Congregationalspecific vocabulary of Sulu texts. 'Eteveni, sometimes known as 'Ateveni, both mean Advent season. The use of Catholic types in the Sulu is not new, making Catholicism related words the main referenced denomination other than the CCCS.

The loanword of Moselemu for the English word Muslim is also interesting. The type was used mainly to compare the distinctions between Christians and Muslims. Today, the Samoan 
government's passing of legislation declaring the nation to be a Christian nation has excluded any other forms of religion in the country (Constitution Amendment Bill No.2, 2016).

Finally, the emergence of the type Tautua Party is the first sign of a hybrid where one word does not take Samoan orthography. This is very rare and does not reappear in the corpus.

\subsection{4) Religious Culture}

With a range of areas, most of the types fall into the sub-categories of church status, formal services, structure and salvation.

Perofeta (prophet -35 tokens) and so 'o (disciple-26 tokens) are the most frequently used types. Both types were never adopted by any Samoan denomination to idealise a particular religious official. So it is not surprising that their use here is based on the context of the Bible. In addition, while most status related types are CCCS, pātele (1 token), a Catholic priest, is the only non-congregational status type in the file.

In terms of church structure, matāgaluega (national church district-25 tokens) and pülega (regional church district-10 tokens) are the most frequent. These types have also shifted in meaning to include national, rather than regional, church confederacies. No structures for other denominations appear.

What I term salvation related types are also widespread. Some examples are:

- Fa'aolaina (salvation) 10 tokens

- Sa'olotoga (freedom) 10 tokens

- Vala'au (calling) 7 tokens

- Ola fa'avavau (eternal life) 6 tokens

- Papatiso (baptism) 6 tokens
- Fānaufouina (re-birth) 3 tokens

- Fa'amaloloina (cured) 1 token

- Puluvaga (protector) 1 token

- Toefuata'iga (repent) 1 token

Of the 30 foreign types in the RC category, only six are new types. These are listed as follows:

- misitērio

- fa'amālōlō

- fanaufouina

- olaga fa'apitoa mystery

heal through Christ 1 token

re-birth (Christian) 3 tokens

ascetic life
2 tokens

2 tokens 
- rosalio

- toefuata 'iga rosary

reformation
1 token

1 token

Interestingly, though the new foreign types in this category are all religiously connected, none account for new religious social status in the church, something which is characterisitic in earlier Sulu texts. The type misiterio and rosalio are commonly used in the Catholic Church. The types fa'amālōlō, Fānaufouina and olaga fa'apitoa all point to ideas of spiritual sustenance.

As a whole, the break-down of the RC category indicates the ascendency of the text towards the upkeep and continuity of the church. Sulu 2014 has shown a shift in sermonry tones from being instructional in 1906 and 1944 to one of prompting. Though very low in type and frequency, the consistent inclusion of Catholic types and an absence of other denominational types in the Sulu may indicate either a close relationship betwen the two denominations, or the existence of denominational disharmony. I suspect the former.

\subsection{5) Social Culture}

A total of 89 types make up the SC category for Sulu 2014. SC category is comprised of many sub-cateogries. These include education, governance, social status, social identity, social role and miscellaneous.

The education sub-category contains the most frequently used type in SC-education with 233 tokens. Other education types include matā 'upu (subject—71 tokens), fa 'au 'uga (graduation20 tokens), pasi (to pass and exam-16 tokens), sipela (spelling-11 tokens), su'esu'ega (research-11 tokens), 'Igilisi (English school subject—8 tokens) and pule (school principal8 tokens). Sikolasipi (scholarship -5 tokens) is a new addition to SC category overall. Sāmoa and New Zealand's treaty of friendship has enabled this trend as mentioned in Section 11.6.

In terms of total types, governance is prevalent with types such as malo laiti (developing nations-100 tokens), tüläfono (law-45 tokens), komiti (committee-17 tokens), fono aoao (constitution -9 tokens), fuai 'upu (clause -9 tokens) and palemene (parliament -7 tokens) some examples. Other new additions to the SC category overall include:

- fa 'alāpotopotoga tuma'oti(National Government Organisation)
- pili
(legislative bill) 
- polokiki

- fa'a'upufai (politics)

(political party)

Social status is dominated by government positions such as:
- fōma' $i$ (doctor)
7 tokens $\bullet$ fömeni (foreman)
2 tokens
- fa'atonu (chief executive)
6 tokens
- fa'asaikolosi (psychologist)
1 token
- ta 'ita 'ifono (meeting chair)
4 tokens $\quad$ lōia
(lawyer)
1 token

Only fomeni is the non-government status in the list above. Fa 'asaikolosi is a new type added to the list of SC types. Seven types are associated with social identity. These are:

$\begin{array}{llllll}\text { - 'Eleni } & \text { (Hebrew) } & 17 \text { tokens } & \text { - } \text { tagata uli }^{30} \text { (African Americans) } & 4 \text { tokens } \\ \text { - 'Eperu } & \text { (Jew) } & 14 \text { tokens } & \text { - pagota } & \text { (prisoner) } & 2 \text { tokens } \\ \text { - milionea } & \text { (millionaire) } & 8 \text { tokens } & \text { - tagata nu'u 'ese } & \text { (stranger) } & 2 \text { tokens } \\ \text { - penisione } & \text { (pensioner) } & 4 \text { tokens } & \text { - ulugali 'i tutusa } & \text { (gay) } & 1 \text { token }\end{array}$

Both 'Eleni and 'Eperu are used in the Bible. Milionea is not used to refer to money but rather to signify countless blessings. Penisione is used to refer to pastors' pension age. Along with pāgota, tagata uli is used to refer to the African slavery periods. Tagata 'o nu' $u$ 'ese is used to associate pastors' social position in their calling to a congregation. Ulugali ' $i$ tutusa is used to refer to same sex couples. Social identity in Sulu 2014 illustrates the fusion between the secular and non-secular aspects of religion and society in general.

A wide range of types are sub-categorised as miscellaneous. As the list below indicates, these types point to activities of unrestricted borrowing in the gagana:

\begin{tabular}{|c|c|c|c|c|c|}
\hline - taimi (tis & & 42 token & - fa'amauina & (document) & 2 tokens \\
\hline - seneturi (ce & & 7 tokens & - misiterio & (mystery) & 2 tokens \\
\hline - fa'ama 'i oti & (HIV) & 3 tokens & - nanu & (speak Englist & \\
\hline - laina & (line) & 3 tokens & & & 2 tokens \\
\hline - maila & (mile) & 3 tokens & - ola fou & (ascetic life) & 2 tokens \\
\hline - paleni & (balance) & 3 tokens & - pasene & (percent) & 2 tokens \\
\hline
\end{tabular}

${ }^{30}$ Tagata uli also referred to Melanesians in Sāmoa. 
- poka

- polōkalame

- kirikiti

- liki (poker) 2 tokens

(programme) 1 token

(cricket)

1 token

(league)
- 'auala fa'ale 'àiga

(family systems theory)

1 token

- mulilua

(adultery)

In this category, 49 of the 89 foreign types are new types. There are a couple of significant foreign types that emerge in the SC category. The first one is 'Amerika mai 'Aferika (African American - 2 tokens) and Lätina (Latin-1 token). These are the first foreign types that make reference to a foreign race, other than Samoan. Another term is the type mami (Egyptian mummy) which refers to the embalming processes of ancient Egypt. Samoans practiced something similar but buried their deceased underground.

Foreign types to do with music are also apparent. Types such as musika (music - 1 token), nota (musical notes-2 tokens) and semikueva (semi-quaver-1 token) were used and pointed to the church's emphasis on its music ministry.

It also seems that the Church is putting emphasis on the health of the family environment. Types such as 'auala fa'ale 'äiga (family systems theory-1 token), 'auala fa'atalavai (dispensary approach-2 tokens), 'auala tu'usa'o (directive approach-2 tokens), galuega fa 'atalatalanoa (counselling-31 tokens) are used in discussion about approaches to family needs.

But perhaps the most prominent area of foreign types in the SC category has to do with government, rather than church. Types such as alaga'oa (resources-1 token), a'oa'oina (education-92 tokens), fa' 'aliliu 'up (translator-1 token), filosofia (philosophy—1 token), fōmeni (foreman - 2 tokens), lesona (lesson-3 tokens), milionea (millionaire -8 tokens), pasi fale (house inspector - 2 tokens), peleti (pastor's wage - 1 token), penefiti (monetary benefit1 token), polokiki (politics-3 tokens), polōmisi (promise-1 token), porōfesa (professor-1 token), pule à'oga (school principal-1 token), su'esu'e (research-11 tokens) and ta'iala (guidelines - 1 token) are some examples.

Other foreign types include:

- fa'ama'i oti

- fa'amauina

- fa'asikolasipi
HIV AIDS

to document

to receive a scholarship
3 tokens

2 tokens

5 tokens 
- $f a$ 'a'upufai

- faiga fa 'apologa

- lama sapatani

- poka

- senituri

- tauvala 'auga political party

slavery

lama sabachthani ${ }^{31}$

poker

century

roll call
1 token

2 tokens

1 token

2 tokens

7 tokens

1 token

The rise in international diseases, such as fa 'ama ' $i$ oti, required educating the Samoan people. The increase in church scholarships for its theological students has also seen the coining of the type fa' asikolasipi, which points to students who have received paid scholarships for continued religious education overseas. The emergence of the type poka, also is significant as it points to the rise in gambling in the country and the passing of legislation by government for the construction of a casino in Sāmoa (Casino and Gambling Control Act 2015).

From the above types there are sub-categories such as occupation, education, economics and social status. Overall, however, the influence of government related types in religious texts is evident. The stabilising of religious types, in comparison, is striking also.

\subsection{6) Material World}

A total of 58 types (189 tokens) comprise the MW category. Kolisi (College) was the most frequently used school building with 27 tokens whereas a new type for church building appears-Mauga (1 token). In traditional Samoan, mauga means mountain. It is also used to refer to the council of chiefs and orators of a village or family. Other new types identified are:

- māketi

- nofoaga mō tagata mātutua

- tifaga

- talavai

- faletalavai

$\begin{array}{ll}\text { (food market) } & 3 \text { tokens } \\ \text { (retirement homes) } & 1 \text { token } \\ \text { (movie theatre) } & 1 \text { token } \\ \text { (chemist) } & 1 \text { token } \\ \text { (chemist) } & 1 \text { token }\end{array}$

${ }^{31}$ A biblical reference to one of Jesus's calls during his crucifixion which means 'why have you forsaken me' 
In previous indicator years, the most dominant building type was a'oga (school). In 2014, $\bar{a}$ 'oga is the seventh most frequent building type (1 token).

Document types were relatively few but referenced consistently. Documents included:

$\begin{array}{llllll}\text { - } t u s i & \text { (book) } & 80 \text { tokens } & \bullet \text { fa'ailoga } & \text { (qualification) } & 4 \text { tokens } \\ \text { - } \text { pepa } & \text { (paper) } & 26 \text { tokens } & \text { - lipoti } & \text { (report) } & 3 \text { tokens } \\ \text { - mau } & \text { (document) } & 6 \text { tokens } & \text { - niusipepa } & \text { (newspaper) } & 1 \text { token } \\ \text { - su'ega } & \text { (exam) } & 5 \text { tokens } & \text { - ripoti } & \text { (report) } & 1 \text { token }\end{array}$

Most document-related types are educational items. The type lipoti is a variation of ripoti. Interestingly, the use of lipoti, considered an informal way of writing report is used.

Food and transport each had seven types. 'Areto (communion bread) was the most frequent food related type with 14 tokens. Coincidentally, 'ava (beer) was the next with 3 tokens. Paka (carpark) was the most frequent transport related type with 10 tokens. Ta'avale (car) was second with 8 tokens.

There were more variations of money related types, such as seleni (shilling) and tala (dollar), were recorded in previous indicator years under MW. This is not the case in 2014. Money related types only included:

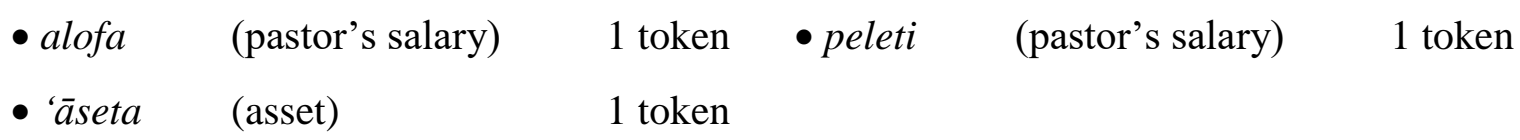

The types alofa and peleti, both meaning pastor's salary, emerge for the first time.

The most frequently used clothing type is 'ofu (clothing) with 28 tokens. The main use of 'ofu is with reference to 'ofu lotu (church clothes) and 'ofu papa'e (white clothes). Other church clothing mentioned is fusiua (tie - 1 token), peleue (church blazer-1 token) and tautaliga (earring-1 token). Solo (towel) is the only non-religious clothing with 1 token.

Types under therapy were mainly medicinal. These included vailā'au foma' $i$ (doctor's medicine -3 tokens), vai (medicine - 2 tokens), fualaau (medicine tablets -1 token) and fuālā'au fa 'asāina (prescription drugs-1 token). 
The dominance of written communication in previous indicator years is less talked about, thus less used. The rapid invention and development in telecommunications has resulted in the less use of written communication and types. In 2014, communication was represented only by the types $t v$ (television-2 tokens), lā'au musika (instrument -1 token) and leitiō (radio-1 token). No other mediums of communication were found.

Two types were categorised under mankind. These are pepe (baby-6 tokens) and mami (Egyptian mummy-1 token). The reason these are part of the MW is because both are nonproper nouns.

The make-up of the MW category in 2014 has its similarities and differences when comparing to previous indicator years. One similarity is the ascendancy in Building related types. One of the main differences is the sub-category breadth which signals an expansion of MW related types in the gagana.

Of the 58 foreign types, 31 are new types. These are listed as follows:

- ala laupapa

- atolā'au

- 'ava

- fa'aili

- sitepu

- fagu

- fale talavai

- fuālā'au

- fuālā'au fa'asāina

- fusiua

- ' ili laupapa

- $\quad k a r i o t a$

- keke

- lā'au musika

- mauga

- nofoaga mo tagata mātutua

- 'ofisa va'ava'ai

$\begin{array}{ll}\text { bridge } & 1 \text { token } \\ \text { ark } & 2 \text { tokens } \\ \text { alcohol } & 3 \text { tokens } \\ \text { whistle } & 1 \text { token } \\ \text { steps } & 1 \text { token } \\ \text { bottle } & 3 \text { tokens } \\ \text { chemist } & 1 \text { token } \\ \text { medicinal tablets } & 1 \text { token } \\ \text { drugs } & 1 \text { token } \\ \text { dress tie } & 1 \text { token } \\ \text { hacksaw/saw } & 1 \text { token } \\ \text { chariot } & 3 \text { tokens } \\ \text { cake } & 1 \text { token } \\ \text { instrument } & 1 \text { token } \\ \text { church building } & 1 \text { token } \\ \text { old people's home } & 1 \text { token } \\ & \\ \text { probation office } & 1 \text { token }\end{array}$

probation office $\quad 1$ token 
- u'amea

- paka

- peleue

- $\quad p i a$

- piliki

- pulumu

- ripoti

- sipuni

- solo

- $s u \bar{o}$

- ta'avale se'e 'i le kiona

e tosoina e ta ifau sleigh

drums

earings

movie theatre
4 tokens

1 token

1 token

2 tokens

2 tokens

1 token

1 token

3 tokens

2 tokens

1 token

1 token

1 token

1 token

1 token

Generally, these types can be categorised under the sub-categories of buildings, transport, food and beverage, medicine, clothing, utensils, transport and music. The dominance of written communication in previous indicator years is less talked about, suggesting being less used. The rapid invention and development in telecommunications have resulted in the lesser use of written communication and thus fewer types. In 2014, communication was represented only by the types $l \bar{a}$ 'au musika (instrument-1 token) and leitiō (radio-1 token). No other mediums of communication were found.

As the most extensive sub-category in Sāvali 2014, five types are classified as buildings in the list above (fale talavai, mauga, nofoaga mo tagata mätutua, ofisa va 'ava 'ai, and tifaga). One type uses the existing word fale, which dominates the building related types in Sāvali 2014 (see Section 5.11.6).

In Section 5.11.6, the foreign type for alcohol was 'ava mālosi. The emergence of the transliteration of beer $(p i a)^{32}$ for alcohol indicates another type which has had a lexical expansion to distinguish between everyday and respectful terms for alcohol.

${ }^{32}$ Like 'ava mālosi, the word pia is commonly used as a blanket term to mean alcohol. 
Another new coinage for church building appears in the type mauga (see Section 5.10.6 for more types for church building), adding to an already comprehensive list.

Clothing, represented by the types fusiua, peleue, solo and tautaliga, provide an interesting point about shifts in clothing styles. The use of fusiua and peleue have become distinct clothing attires for the Congregational and Methodist denominations, in particular. Catholics, in particular parishoners, in contrast, have a more relaxed dress code for church.

While the majority of types are loanwords, the types nofoaga mo tagata mātutua and ta 'avale se'e 'i le kiona e tosoina e ta 'ifau are comprised of a mixture of existing indigenous words and transliterations.

The make-up of the MW category in 2014 has its similarities and differences when comparing to previous indicator years. One similarity is the ascendancy in Building related types. One of the main differences is the sub-category breadth which signals an expansion of MW related types in the gagana.

\subsection{7) Natural Environment}

With only three types in 1977, eleven foreign types were found in 2014. The most used and referenced NE types are animals. Gata (snake) is the most frequently used with 23 tokens. The rest are comprised of:

$\begin{array}{llllll}- \text { maile } & (\operatorname{dog}) & 7 \text { tokens } & \bullet ' \text { āsini } & \text { (donkey) } & 2 \text { tokens } \\ \text { - leona } & (\text { lion }) & 2 \text { tokens } & \bullet ' \text { àeto } & \text { (eagle) } & 1 \text { token }\end{array}$

Like Sulu 1977, the majority of types are again used in a biblical context, particularly leona, asini and aeto, which are not found in Sāmoa.

Vine (grapes - 3 tokens), karite (lethek -2 tokens) and meli (meil ${ }^{33}-2$ tokens) make up the fruit and vegetable sub-category. The natural landscape is represented more than ever with depictions by the types konetineta (continent - 1 token), setete (state-1 token), kiona (snow1 token), penisula (peninsular-1 token) and tapeneto (oak tree-1 token).

Of the eleven foreign types, nine are new types:

${ }^{33}$ French for 'honey'. 
- ' ‘̄sini

$$
\text { donkey }
$$

2 tokens

- karite

lethek ${ }^{34}$

2 tokens

- kiona

snow

lion

$\operatorname{dog}$

honey

olive

peninsula

- penisula

- ta'ifau
1 token

2 tokens

7 tokens

2 tokens

4 tokens

1 token

3 tokens

Note the two types for dog (maile and ta ifau). These are not uncommonly used today. The type ta ifau is the respectful term for dog, while maile is the everyday term. In some cases, these terms are used as derogoratory references. The type karite is unheard of in everyday Samoan conversation and is thus considered a biblical reference only. The types 'assini, kiona, leona, meli, 'ólive and penisula, however, are in common usage today.

\subsection{8) Other}

The two foreign types in the OTH category are faitau (read-3 tokens) and sipela (to spell-1 token). Faitau is collocated to remind readers of the importance of reading church documents such as the bible, prayer books and sermons. Sipela, however, is used in reference to the importance of spelling in children's religious education.

\subsection{9) Overview of Sulu 2014 findings}

In all the categories, there has been a multiplication of foreign types. With a total of 311 foreign types, 196 are new types. Overall, the 2014 foreign types in Sulu account for $32 \%$ of the all foreign types in Sulu and $16 \%$ of the total foreign type corpus. What we can learn from Sulu 2014 is the notion that the gagana has expanded through a continued adapting to its many lived contexts.

\footnotetext{
${ }^{34}$ Lethek is an ancient counting system used in the Bible
} 


\subsection{3) ILOILOGA TĀUA: Main Findings}

Table 19, Table 20, and Figure 3 provide a snapshot of the overall picture for both the Sāvali and Sulu from 1906 to 2014, while Figure 4 provides a picture of the entry of new types into the lexicon. 
Table 19:

Sulu 1906-2014

\begin{tabular}{|c|c|c|c|c|c|c|c|c|c|c|c|c|c|c|c|c|c|c|c|c|}
\hline \multirow{3}{*}{ CATEGORY } & \multicolumn{16}{|c|}{ INDICATOR YEARS } & \multirow{2}{*}{\multicolumn{4}{|c|}{$\begin{array}{c}\text { TOTAL TYPES \& } \\
\text { TOKENS } \\
1906-2014\end{array}$}} \\
\hline & \multicolumn{4}{|c|}{1906} & \multicolumn{4}{|c|}{1944} & \multicolumn{4}{|c|}{1977} & \multicolumn{4}{|c|}{2014} & & & & \\
\hline & Type & $\%$ & Token & $\%$ & Type & $\%$ & Token & $\%$ & Type & $\%$ & Token & $\%$ & Type & $\%$ & Token & $\%$ & Types & $\%$ & Token & $\%$ \\
\hline 1. Place Names & 84 & 19 & 281 & 10 & 21 & 16 & 41 & 7 & 13 & 11 & 22 & 7 & 40 & 13 & 187 & 10 & 158 & 16 & 531 & 10 \\
\hline 2. Proper Nouns & 107 & 24 & 791 & 28 & 43 & 33 & 239 & 44 & 42 & 35 & 163 & 53 & 81 & 26 & 295 & 17 & 273 & 27 & 1488 & 27 \\
\hline 3. Religious Culture & 105 & 23 & 924 & 32 & 27 & 21 & 174 & 32 & 20 & 17 & 45 & 14 & 30 & 10 & 301 & 17 & 182 & 18 & 1444 & 26 \\
\hline 4. Social Culture & 66 & 15 & 457 & 16 & 25 & 19 & 61 & 11 & 23 & 19 & 46 & 15 & 89 & 28 & 734 & 41 & 203 & 20 & 1298 & 24 \\
\hline 5. Material World & 62 & 14 & 331 & 12 & 12 & 9 & 24 & 5 & 19 & 16 & 24 & 9 & 58 & 19 & 189 & 11 & 151 & 15 & 569 & 10 \\
\hline 6. N/Environment & 18 & 4 & 40 & 1 & 2 & 2 & 8 & 1 & 3 & 2 & 7 & 2 & 11 & 3 & 45 & 3 & 34 & 3 & 100 & 2 \\
\hline 7. Other & 4 & 1 & 44 & 1 & 0 & 0 & 0 & 0 & 0 & 0 & 0 & 0 & 2 & 1 & 4 & 1 & 6 & 1 & 48 & 1 \\
\hline $\begin{array}{c}\text { TOTAL TYPES \& } \\
\text { TOKENS PER } \\
\text { INDICATOR YEAR }\end{array}$ & $\begin{array}{c}446 \\
(44 \%)\end{array}$ & 100 & 2868 & 100 & $\begin{array}{c}130 \\
(13 \%)\end{array}$ & 100 & 544 & 100 & $\begin{array}{c}120 \\
(12 \%)\end{array}$ & $\begin{array}{c}10 \\
0\end{array}$ & 307 & 100 & $\begin{array}{c}311 \\
(31 \%)\end{array}$ & $\begin{array}{c}10 \\
0\end{array}$ & 1755 & 100 & $\underline{1007}$ & 100 & $\underline{5478}$ & 100 \\
\hline
\end{tabular}

\subsection{1) Key points from Table 19}

A number of conclusions can be made based on the findings presented in this chapter:

- 1906 and 2014 were significant years in the total number of foreign types.

- In the interim years of 1944 and 1977, fewer foreign types were used.

- The category with the most foreign types is PN (273 types from 1906-2014). This is followed by SC (203 types), RC (182 types), PLNs (158) and MW (151 types). 
- Both the NE (34 types) and particularly OTH (6 types) categories contributed an insubstantial amount of foreign types

- The most frequently used type in each of the Sulu is the PN Atua (1906 - 163 tokens, second behind Iesu with 194 tokens; 1944 - 84 tokens; 1977 - 89 tokens and $2014-485$ tokens).

- In total, foreign types in the PN category (1488 tokens) are used more frequently than any other category.

- Very few foreign types are verbs (OTH category).

Table 20:

Sāvali 1906-2014

\begin{tabular}{|c|c|c|c|c|c|c|c|c|c|c|c|c|c|c|c|c|c|c|c|c|}
\hline \multirow{3}{*}{ CATEGORY } & \multicolumn{16}{|c|}{ INDICATOR YEARS } & \multirow{2}{*}{\multicolumn{4}{|c|}{$\begin{array}{c}\text { TOTAL TYPES \& } \\
\text { TOKENS } \\
1906-2014\end{array}$}} \\
\hline & \multicolumn{4}{|c|}{1906} & \multicolumn{4}{|c|}{1944} & \multicolumn{4}{|c|}{1977} & \multicolumn{4}{|c|}{2014} & & & & \\
\hline & Types & $\%$ & Tokens & $\%$ & Types & $\%$ & Tokens & $\%$ & Types & $\%$ & Tokens & $\%$ & Types & $\%$ & Tokens & $\%$ & Types & $\%$ & Tokens & $\%$ \\
\hline 1. Place Names & 10 & 9 & 23 & 4 & 6 & 6 & 18 & 3 & 15 & 5 & 25 & 1 & 17 & 3 & 62 & 3 & 48 & 5 & 128 & 2 \\
\hline 2. Proper Nouns & 29 & 27 & 146 & 25 & 18 & 19 & 140 & 23 & 115 & 38 & 332 & 12 & 27 & 6 & 160 & 7 & 189 & 19 & 778 & 12 \\
\hline 3. Religious Culture & 15 & 14 & 57 & 10 & 18 & 19 & 112 & 19 & 5 & 2 & 111 & 4 & 36 & 8 & 155 & 6 & 74 & 7 & 435 & 6 \\
\hline 4. Social Culture & 29 & 27 & 292 & 50 & 32 & 33 & 137 & 23 & 94 & 31 & 2133 & 74 & 269 & 58 & 1582 & 65 & 424 & 44 & 4144 & 64 \\
\hline 5. Material World & 20 & 19 & 54 & 9 & 21 & 22 & 183 & 31 & 53 & 18 & 244 & 8 & 98 & 21 & 356 & 15 & 192 & 20 & 837 & 13 \\
\hline 6. N/Environment & 3 & 3 & 3 & 1 & 1 & 1 & 1 & 1 & 17 & 6 & 22 & 1 & 19 & 4 & 99 & 4 & 40 & 4 & 125 & 2 \\
\hline 7. Other & 1 & 1 & 5 & 1 & 0 & 0 & 0 & 0 & 0 & 0 & 0 & 0 & 0 & 0 & 0 & 0 & 1 & 1 & 5 & 1 \\
\hline $\begin{array}{c}\text { TOTAL TYPES \& } \\
\text { TOKENS PER } \\
\text { INDICATOR YEAR }\end{array}$ & $\begin{array}{c}107 \\
(11 \%)\end{array}$ & 100 & 580 & 100 & $\begin{array}{c}96 \\
(10 \%)\end{array}$ & 100 & 591 & 100 & $\begin{array}{c}299 \\
(31 \%)\end{array}$ & 100 & 2867 & 100 & $\begin{array}{c}466 \\
(48 \%)\end{array}$ & 100 & 2414 & 100 & 968 & 100 & 6452 & 100 \\
\hline
\end{tabular}




\subsection{2) Key points from Table 20}

- Apart from 1944, where only 96 foreign types were identified, the indicator years 1977 (299 types - 31\%) and 2014 (466 types - 48\%) indicate increases in foreign type integration. These increases are relative to Samoan independence and diasporic movements of Samoans.

- The SC category (424 types - 42\%) has contributed the most foreign types compared to any other category.

- Like the Sulu files, both the NE (40 types-4\%) and OTH (1 type-1\%) contributed insubstantial amounts of foreign types.

- Unlike the Sulu, however, which revealed the most frequently used type in all the files as Atua, the Sāvali reveals different frequently used type for each indicator year. These are:
1906: Ali ${ }^{i} i$ (Christian God)
75 tokens
1977 itū tagi (plaintiff)
411 tokens
1944: tusi (book/letter)
107 tokens
2014: malo (government)
329 tokens

- In total, types in the SC category (4144 tokens) are used more frequently than any other category. This is followed by the MW category (837 tokens), PNs (778 tokens), RC (435 tokens), PLNs (128 tokens), 125 (145 tokens) and OTH (5 tokens)

- Very few foreign types are verbs 
Figure 3:

$\underline{\text { Total Category Types in Corpus }}$

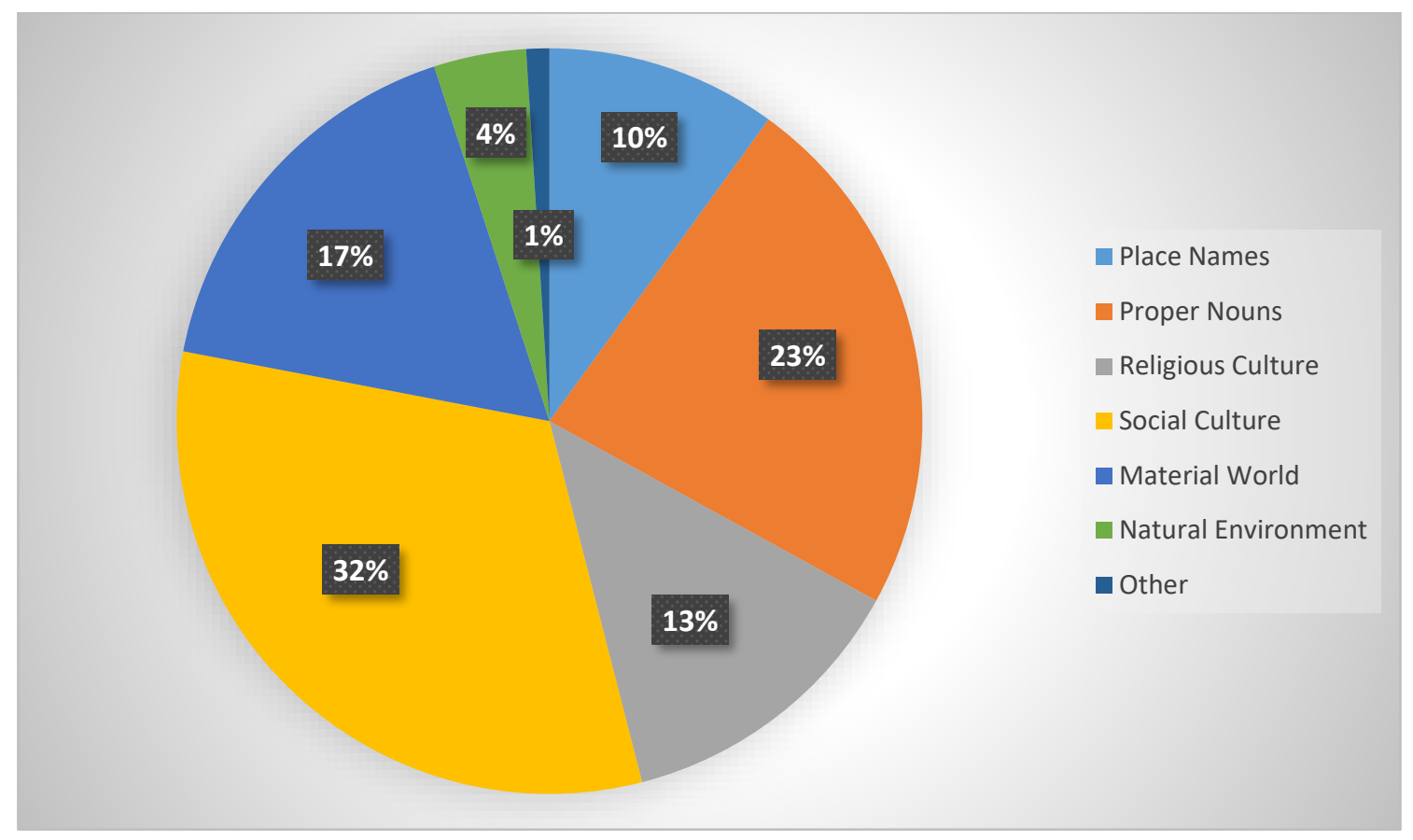

- Both the Sulu (970) and Sāvali (968) have contributed similar numbers of foreign types into the gagana.

- SC has contributed the most foreign types with 627 or $32 \%$ of the total corpus. This is followed by:

- PNs: 462 types $\quad(23 \%)$

- MW: 343 types $\quad(17 \%)$

- RC: 256 types $(13 \%)$

- PLNs: 206 types $\quad(10 \%)$

- NE: 74 types $\quad(4 \%)$

- OTH: 7 types $\quad(1 \%)$

Total $1,975 \quad(100 \%)$

The corpus produced a wordlist of 1,975 foreign types. These types entered the lexicon at different times. Figure 4 shows the proportion of overall total types entering for each indicator 
year. The types in Figure 4 are the combined total numbers of foreign types for each indicator year for both Sulu and Sāvali.

\section{Figure 4:}

Total Types for Sāvali and Sulu 1906-2014

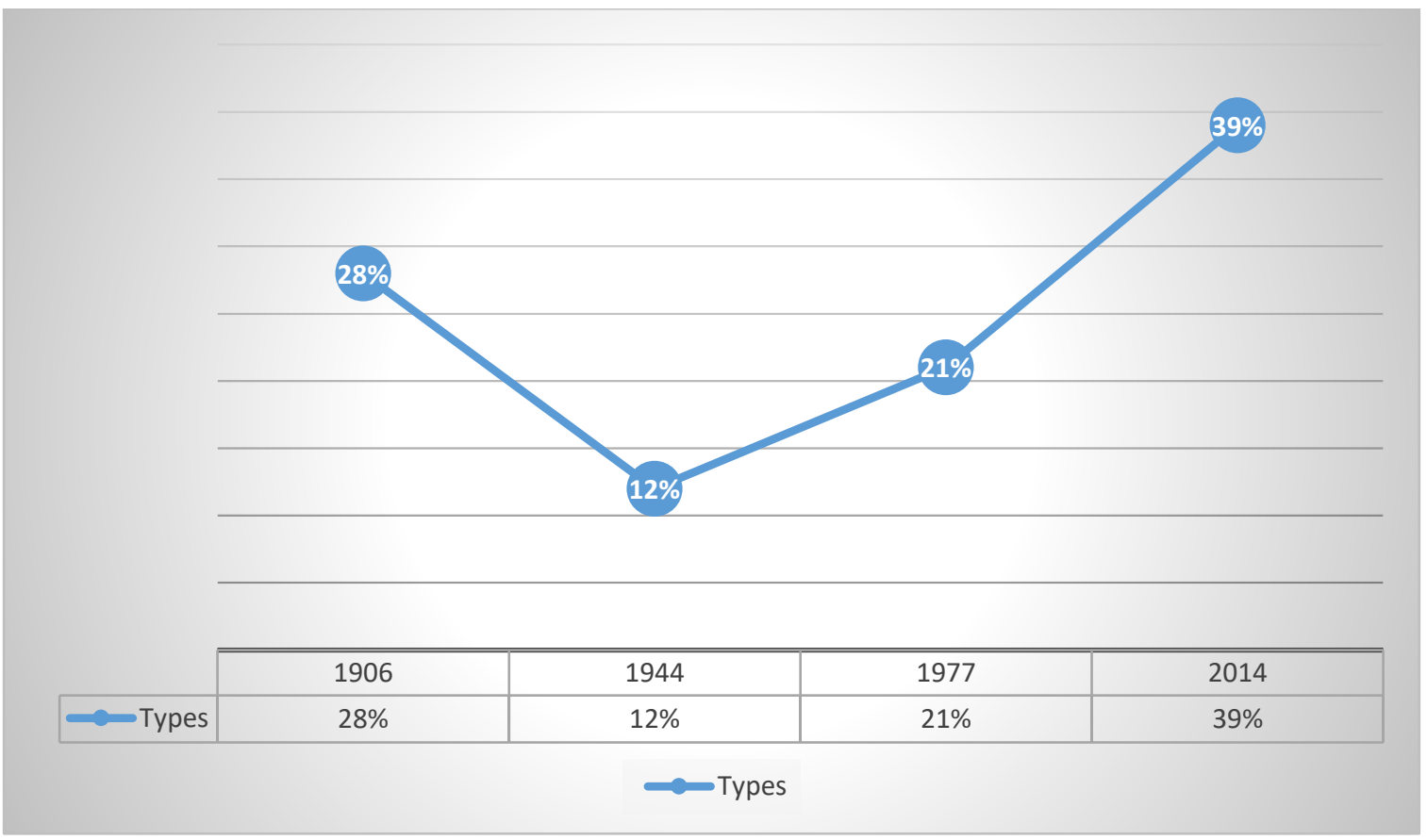

As can be seen in Figure 4, there has been a steady increase in the appearance of new types since 1944, with the result that the indicator year 2014 saw the highest percentage of foreign types being integrated into the gagana. Compared to other indicator years, foreign words were used more frequently in the combined lāuga sources in 2014, also (Tables 19 \& 20).

\subsection{4) AOTELEGA: Conclusion}

The aim of this chapter was to present the corpus findings for both Sāvali and Sulu files for the indicator years 1906, 1944, 1977 and 2014.

Diachronically, the findings suggest that from 1906 to 1977, there was a gradual influx of foreign types (words and meaning) into the gagana. With the influx of foreign terms most apparent in the period 1977-2014.

The majority of change in the gagana has been in the area of social culture, proper nouns (names), material resources, religious culture and place names. The next chapter provides a synthesis of the findings in chapters four and five. 


\title{
CHAPTER SIX
}

\section{FA'ATALATALANOAGA}

\author{
Discussion
}

\section{1) INTRODUCTION}

Chapters Four and Five have demonstrated that the gagana is shaped by a complex network of social processes. It is for this reason that changes in the gagana are not independent of the social context the language is a part of. The events of Christianity arriving on Samoan shores, colonial administration occupation, and political movements to regain independence, and migration, for instance, have impacted significantly on the lexical composition (form and meaning) of the gagana.

This chapter presents a synthesis of the findings in Chapters Four and Five. The synthesis is organised into three main sections. The first section is a synthesis of the Fa'afaletui findings in Chapter Four and the foreign word list findings in Chapter Five. The synthesis is organised into four themes: (1) missionary influence, (2) the influence of English on the gagana, (3) written Samoan and (4) lexical shifts. The aim is to discuss how qualitative oral perceptions of informed insiders and quantitative corpus research findings coincided or differed.

The second section is a discussion on how foreign types are integrated into the gagana using Macalister's (2007) LOLC model. The discussion provides new information on the various lexical forms (Tables 22, 23 and 24) and how these LOLC have developed over time (Table 25). The objective of this discussion is to gain insight into how the foreign type integration unfolds, how these may look in lexical form, and how new introductions marry with existing types.

The final section is a discussion of how lāuga fa 'amatai and lāuga fa' 'alelotu, as representations of the chiefly and religious discourses respectively, are reflected in the findings. The aim is to identify key interpretations of the similarities and differences of these discourses.

This chapter concludes with interpretations from the above sections. In addition, the discussion indicates that the empirical examination of the gagana in this thesis has yielded new insights contributing to the growing scholarship about gagana Sāmoa. 


\section{2) FA'AFALETUI AND CORPUS FINDINGS: A Discussion}

\subsection{1) Missionary influence}

A key observation made during the fa 'afaletui sessions in Section 2.1 of Chapter Four was the high degree of mission influence on foreign type integration in the gagana. Informants, such as Ioane and Ioelu, for instance, stated that missionary influence transpired from interdenominational rivalry and Bible translation.

The foreign word list findings in Chapter Five support insider informants' perceptions of the extensive influence of the missionaries on the gagana. Though types associated with RC represented 13\% (256 types) of total types, third only to SC (32\%) and PNs (22\%), the influence of Christianity on the gagana is evident across most categories. PNs, for instance, consist of types such as 'Amosa (Amos), 'Āpera'amo (Abraham) and others. Biblical places such as 'Isara'elu (Israel) and Pētele'ema (Bethlehem) are listed under PLN. Physical buildings such as fales $\bar{a}$ (church building) and $\bar{a}$ 'oga (missionary school) are categorised under MW. In addition, types such as faīa 'oga (teacher), faife 'au (pastor) and fuaitau (paragraph) are prevalent in the SC category. These examples demonstrate the overall influence of Christianity on changes to the gagana which have come about due to numerous influences such as the written text, particularly the Bible, and the idea that much of what had been established by the missions was emulated by the administrations.

The corpus findings also supports denominational rivalry as an influence of significance on the gagana. Types such as Toeā ina (Congregational Elder pastor), Sea (Methodist Elder pastor), 'Akiepikopō (archbishop), 'Akelikana (Anglican), 'Ekālesia 'o le 'Aupa'ia e Gata Ai (Mormonism), fa'afeagaiga (Congregational pastor), tausi matāgaluega (Methodist pastor) and $t i$ ' $a$ kono (Catholic pastor), for instance, are denominational-specific types and products of inter-denominational rivalry. These types, along with many others, reflect Ioane, Pita and Tina's discussion about denominationally specific coinages in section 2.1 which also includes Saga's reflections about the openness of lexical integration amongst church groups in section 2.2 of Chapter Two.

The influence of Christianity on changes to the gagana is without question. It was already, at least anecdotally known, even academically surmised, but is now corroborated and evidenced by data that marries insider fa 'afaletui sessions and the foreign word list findings. Considering, then, that the language of the missions was English, do the findings suggest that English is the main colonial language from which foreign types have been sourced into the gagana? 


\subsection{2) The influence of English}

Before a discussion regarding the influence of English on the gagana is presented here, it is important to acknowledge that before the gagana came into contact with English, English had been in contact with many other languages. As a result, many English words derive from other languages, such as Greek and Latin. Though this is useful background, this discussion focusses only on language contact between Samoan and English, and other colonial languages such as German. As a result, etymological considerations will not be included. It is considered highly likely that the missionaries and administrations drew from their first language (usually English), rather than from Greek or Latin, in their language and policy planning strategies in Sāmoa.

A key argument made in Section 15 of Chapter Two is that current research about gagana change is largely observational. This study, therefore, has been motivated by the idea that empirical research will enhance current knowledge. Kruse-Vā'ai (2011) and Macpherson (2010) provide substantial accounts of the influence of foreign languages, particularly English, on the gagana. In addition, Saga reflects in section 2.2 of Chapter Three about the extensive amounts of English, and to a lesser degree German, words in gagana today. The word list findings enhance Kruse-Vā'ai, Macpherson and Saga's accounts of the influence of English on the gagana.

Data from the word list findings indicate that most foreign types in the gagana have been integrated from English. Apart from a few words which are borrowed from either Tahitian, such as fa 'aipoipoga (fa 'aipoipora' $a$ in Tahitian — wedding), pulela 'a (purera' $a$ in Tahitianchurch altar), $p \bar{\imath}$ (pī in Tahitian—alphabet), 'api ('api parau in Tahitian—school book) and luko (ruto in Tahitian-wolf), or Tongan such as lotu (lotu in Tongan-religion, church, congregation) (see Cain 1986; also see section 13-Chapter Two), over ninety percent of foreign types identified in the word list are from English.

Types such as 'Afa (Arthur), 'Aperila (April—month of the year), 'Esoto (Exodus-Bible chapter), foseferi (phosphate) and 'Initia (India) are some examples. General nouns are also extensive and include types such as misiterio (mystery), mami (mummy), pāleni (balance), paka (park or butter), musika (music), komiti (committee), komisi (commission), kāmela (camel), iata (yard) and alaisa (rice). But not all types are phonologically integrated. Types such as fa 'amalama (window), matāgaluega (church district), là'au lomitusi (typewriter) and vaiasosā (Sunday week) are types coined using existing vocabularies. A more comprehensive 
analysis of the influence of English is provided in section 3 of this chapter where the LOLC categories are analysed.

While Kruse-Vā'ai, Macpherson and insider informants' accounts about the high influence of English on the gagana is supported here, so too is Saga's observation of the limited influence of German words ${ }^{35}$. Types such as Kaisa (Kaiser), Kaisalina (Kaisa's wife), Kaisalika (Imperial government), maka (German mark-currency), ametimani (amtmann) and Feterika (Friedrich), are obsolete terms and if used, are done so as historical reference. These types do not re-appear after 1906 and have come about as a result of German administration departure in 1914 (see section 11 - Chapter Two). Overall, it is in the category of nouns (proper and general), where almost all, is where English has the most presence in the gagana.

\subsection{3) Written Samoan}

One of the main concerns raised by insider informants in the fa 'afaletui sessions was the lack of a standardised gagana (see section 2.3-Chapter Four). For some, such as 'Ina and Tina (see section 2.3- Chapter Four), there is a strong need for gagana standardisation (mainly in the areas of spelling or diacritic usage) for educational and formal reasons. The loss of standardisation which 'Ina and Tina lament is almost certainly due to the progressive demise of the a'oga faife 'au (pastors' schools) which prioritised the teaching of the Samoan grammar. In recent times, particularly here in New Zealand, the value of the $\bar{a}$ 'oga faife 'au for language learning and maintenance has led to a national drive to re-introduce them in all EFKS congregations across New Zealand. This has been formalised by the establishment of the Ekalesia Fa'apotopotoga Kerisiano Sāmoa New Zealand Trust (EFKSNZT). In 2019, the EFKSNZT met with the Samoan language department at $\mathrm{Va}^{\text {'aomanu }}$ Pasifika to assist and advise on their newly proposed curriculum for teaching and learning Samoan. Others, such as Sina, accept the non-standardised characteristic of the gagana (albeit after a certain point of demonstrated competency) as something beneficial for literary expression and semantic flow. In addition, this argument posits a self-determination argument which seeks to privilege Samoans' control over their own orthographic development, thus detaching the gagana from Western conceptualisations of orthography that seem to

\footnotetext{
${ }^{35}$ There is evidence to suggest that the German language was not a major influence in Sāmoa. Work by Stolberg (2013) suggests that apart from the Germans themselves, only a few Samoans were fluent or could hold a conversation in German. The Germans were also said to prefer speaking in English, too.
} 
actively undermine that. The literature on written Samoan highlights some of the frustrations associated with a lack of a standardised gagana. The objective of having a written gagana, at least for the missionaries, was both practical and ideological. The quickest way to gain religious conversion across diverse populations was to make the gospel available in their languages. Because of this objective and due to the fact that many were not linguists (see Ma'ilo 2016), it was never their priority to standardise the gagana (see section 13-Chapter Two). The results in this study reveal interesting discussion points about gagana standardisation.

All foreign types show a complex and inconsistent Samoan orthography. Based on the findings of this research, the orthography of foreign types in gagana reflect these important points:

1. The standardising complexities of the gagana lie in (1) the use of the Bible as the source of correct Samoan orthography and, (2) in the case when an equivalent cannot be found in the Bible that orthography becomes vulnerable to various ways of writing.

2. The inconsistency of the use of diacritical marks (glottal stop and macron).

\subsubsection{1) Samoan and foreign type orthography}

Although Ma'ilo (2016) admits to limited linguistic expertise, he argues that the missionaries in Sāmoa were not concerned with correct orthography but were instead preoccupied with the importance of constructing a written orthography to assist and speed religious conversion and understanding of Samoans of the Christian gospel.

With this said, there is no clear explanation of why some types are spelled the way they are. In essence, it comes down to the writer's interpretation. To complicate things even more, the writer's interpretation can be influenced by his or her own cultural and religious (denominational) contexts and preferences. Consider, for instance, the following foreign types:

Table 21:

Foreign type orthography

\begin{tabular}{|c|c|}
\hline Samoan orthography & English translation \\
\hline peretiso and parataiso & paradise \\
\hline Sione Ueselē and Ioane Viliamu & John Williams \\
\hline faleā'oga and fale $\overline{\text { a' }}$ 'oga & School buildings \\
\hline Ianuari and Ianuali & January \\
\hline
\end{tabular}




\begin{tabular}{|c|c|}
\hline 'ekelesia and 'ekälesia & Church congregation \\
\hline kirikiti and kilikiti & Samoan cricket \\
\hline
\end{tabular}

The examples in Table 21 show how complex Samoan orthography can be. The differences between peretiso and parataiso lie in the first ( $p e \& p a$ ), second ( $r e$ and $r a$ ) and penultimate ( $t i$ and tai) syllables. There are many examples like this such as Ianuari and Ianuali (January). The types Sione Ueselē and Ioane Viliamu, which both mean John Williams, show Methodist and Congregational lexical differences, something outlined in section 13 of Chapter Two and addressed by Ioane and Pita in section 2.1 of Chapter Four. The hybrid fale $\bar{a}$ ' $o g a$ and fale $\bar{a}$ 'oga show differences in the orthography of types coined using existing and foreign types. Two interpretations can be made of the types kilikiki, kirikiti and kilikiti. The first is lexical variation, which is prevalent in the word list. The second, and more important, is the inconsistency in the use of the t-style and k-style registers (see section 6.1-Chapter Two). The type kirikiti is in the t-style while kilikiki and kilikiti are written in the k-style. However, the appearance of the variations of Samoan cricket is more prevalent in the earlier indicator years than in 1977 and 2014 , indicating that the gagana is more likely to have some form of standardisation today than in earlier indicator years.

\subsubsection{2) Diacritical marks}

The use of fa'ailoga 'o le gagana (diacritical marks), namely the koma liliu (glottal stop) and fa 'amamafa (macron), is also inconsistent throughout the files. Fa'ailoga 'o le gagana are less used in 1906 and 1944 but are increasingly used in 1977 and 2014. It is highly likely that the increased use of fa 'ailoga 'o le gagana during the later indicator years is a result of increasingly bilingual and semi-fluent readers and learners of the church's parishioners and population in general, particularly as both Sulu and Sāvali are printed and accessible online today, as well as the influence of overseas and return migration. The inconsistent state of Samoan orthography can be traced again to the influence of the missionaries, including their influence over lexical shifts where existing words were replaced with new types. The lexical inconsistencies were heightened by Aiono Fanaafi Le Tagaloa, as the former Director of Education in Sāmoa from 1968-1975, where she pushed, and successfully removed, vowel length markers and glottal stops from all educational texts. For some time thereafter, students were not exposed to the importance of these diacritical markers. They were reinstated only when the consequences 
became clear in the misuse of language in government. These findings support Sina's commentary about the politics of gagana standardisation where she reflects on how the gagana is adapted according to context (see section 2.3-Chapter Four). The move for selfdetermination strategies consistent with decolonisation movements impact here as Samoans attempt to resist standardisation as a means for self-determination. Debates over diacritic use are passionate and polarising. This can and has stalled efforts to standardise written gagana (see work of the Samoan Language Commission).

\subsection{4) Lexical shift}

The eradicating of Samoan indigenous words, such as nunuavaga, tini and pōula from being spoken or practiced by Samoans because they were aligned to customs considered heathen by the missions, is a key theme in both the literature review (see section 13-Chapter Two) and fa' 'afaletui (see section 2.1 of Chapter Four). The findings in this research show that many words that were abolished during missionary occupation remain in Samoa's pre-colonial lexicon. This finding supports Ma'ilo (2016), Ioane and Sina's (see sections 2.1 and 2.5Chapter Four) pleas to decolonise religious texts through the revival and reintroduction of indigenous types, such as feagaiga, to help indigenise foreign ideologies as a selfdetermination strategy.

But while the fate of many of Samoa's pre-colonial terms show no signs of being revived, there has been an increase in the use of a large number of indigenous words in lexical coinages for foreign types. The word list reveals that in the discourse of lāuga fa 'amatai, the indicator years 1977 and 2014 consist of a high amount of loan translation and hybrid coinages compared to 1906 and 1944. Types such as fofoga fetalai (speaker of the house), fa'aitiitiga 'o le aoga (depreciation), mavaega tausi (trusts act), fa'atau tu'i (mortgage sale), upega tafā'ilagi (internet), gasegase (outpatient) and vaitusi (ink), all consist of indigenous Samoan words used to make sense of (i.e. to indigenise) foreign ideologies and concepts. This empirical study has shown that language authorities, particularly government bodies, are taking heed of language maintenance and survival, albeit in a somewhat haphazard and more political than evidence based way.

A more comprehensive discussion of loan translations and hybrids, along with other LOLC categories such as loanwords, semantic loans and neologisms, is provided in the subsequent section. 


\section{3) LEXICAL OUTCOMES OF LANGUAGE CONTACT}

Language contact between the gagana and foreign languages have yielded five types of lexical expansions, known here as Lexical Outcomes of Language Contact (LOLC). These are:

1. loanwords

2. semantic loans

3. loan translations

4. hybrids and

5. neologisms

The LOLC categories used in this research have been adapted from Macalister's (2007, p. 495) LOLC categories, which were established based on his examination of the presence of Maori words in New Zealand English. Modifications of the hybrid and neologism categories were made based on the lexical constructions in Samoan. While the descriptions of loanwords, semantic loans and loan translations were similar in Samoan and Macalister's study, hybrids and neologisms, however, were modified. Where A is the foreign language and B is Samoan, Table 22 provides a full break-down of each LOLC:

Table 22:

Lexical Outcomes of Language Contact (LOLC) for Samoan Types

\begin{tabular}{|c|c|c|c|c|c|}
\hline & Loanwords & $\begin{array}{c}\text { Semantic } \\
\text { Loans }\end{array}$ & $\begin{array}{c}\text { Loan } \\
\text { Translations }\end{array}$ & Hybrids & Neologisms \\
\hline Meaning & From A & From A & From A & From A & From A \\
\hline Form & $\begin{array}{l}\text { From } B \text { : } \\
\text { a new word } \\
\text { added to the } \\
\text { Samoan } \\
\text { lexicon, and } \\
\text { taking } \\
\text { Samoan } \\
\text { orthography }\end{array}$ & $\begin{array}{l}\text { From B: } \\
\text { a new } \\
\text { meaning } \\
\text { added to an } \\
\text { existing word } \\
\text { in the gagana } \\
\text { but its } \\
\text { meaning is } \\
\text { based on a } \\
\text { foreign model }\end{array}$ & $\begin{array}{l}\text { From B: } \\
\text { a new word } \\
\text { created from } \\
\text { existing } \\
\text { words in the } \\
\text { gagana but } \\
\text { its meaning is } \\
\text { based on a } \\
\text { foreign model }\end{array}$ & $\begin{array}{l}\text { From B: } \\
\text { a new word } \\
\text { comprised of } \\
\text { an existing } \\
\text { word and a } \\
\text { foreign word } \\
\text { which has } \\
\text { taken Samoan } \\
\text { orthography }\end{array}$ & $\begin{array}{l}\text { From B: } \\
\text { a new word } \\
\text { created from } \\
\text { two or more } \\
\text { foreign types } \\
\text { which have } \\
\text { taken Samoan } \\
\text { orthography }\end{array}$ \\
\hline
\end{tabular}




\begin{tabular}{|c|c|c|c|c|c|}
\hline $\begin{array}{c}\text { Example } \\
\qquad\end{array}$ & $\begin{array}{c}\text { - Kaisa } \\
\text { (Kaiser) } \\
\text { - konesula } \\
\text { (consular) } \\
\text { - kilomita } \\
\text { (kilometre) }\end{array}$ & $\begin{array}{l}\text { - Atua } \\
\text { (God) } \\
\text { - a 'oa 'o (lay } \\
\text { preacher) } \\
\text { - Afioga } \\
\text { (Bible) }\end{array}$ & $\begin{array}{l}\text { - Agaga } \\
\text { Pa ia } \\
\text { (Holy } \\
\text { Spirit) } \\
\text { - faife 'au } \\
\text { (pastor) } \\
\text { - tusi faitau } \\
\text { (Church } \\
\text { Bible } \\
\text { Reading } \\
\text { Booklet) }\end{array}$ & $\begin{array}{l}\text { - 'au lotu } \\
\text { (congregatio } \\
\text { n) } \\
\text { - Aso } \\
\text { Faraile } \\
\text { (Friday) }\end{array}$ & $\begin{array}{l}\text { - 'Ofisa } \\
\text { sinia } \\
\text { (Main } \\
\text { office) } \\
\text { - Lotu } \\
\text { Luteru } \\
\text { (Brethren } \\
\text { Church) }\end{array}$ \\
\hline
\end{tabular}

\subsection{1) Hybrid and Neologisms in the gagana}

There are reasons why the adaptations were made to the hybrid and neologism categories. Firstly, it was discovered that hybrids in the gagana existed in two lexical constructs. The first lexical construct is comprised of an existing word and a loanword. An example is the type 'au lotu (sometimes spelt 'aulotu) meaning a church congregation. ' $A u$ is an existing word which refers to a group of people. Lotu, meaning church, however, is a Tongan word, which has taken Samoan orthography ${ }^{36}$. In comparison, unlike the hybrids Maoridom and huia bird identified by Macalister in his work, where Maori is an existing term and -dom is a foreign suffix, all foreign types in the gagana take Samoan orthography.

The second hybrid construct is again comprised of two (or more) types. One of the types is again an existing type. The second type, however, and this is where it is different to the first lexical construct, is a semantic loan. An example is the type faletupe (bank). Both fale and tupe are existing words. Fale, is an existing type meaning house which has maintained its indigenous meaning in the hybrid construct. However, tupe has had a new meaning added to denote money. In pre-contact times, tupe referred to a small, flat coconut disc used in taulafoga (disc throwing). Note that the two hybrid constructs are Samoan in form.

Neologisms in the gagana take three lexical structures. The first is comprised of two (or more) loanwords. An example is the type 'ofisa sinia (main office). Both loanwords, 'ofisa and sinia

${ }^{36}$ Note lotu is also the spelling for church in Tongan. 
are the transliterations of the English words office and senior, respectively. The second type of neologism is comprised of a loanword and a semantic loan. An example is the type $l \bar{a}$ 'au musika (musical instrument). Là'au, a semantic loan, means instrument. Its pre-contact meaning refers to a tree or a piece of wood. Musika, a loanword, is a transliteration of the English word music. The third neologism structure is comprised of two semantic loans. Consider, for instance, the word tusi tupe (bank account). The indigenous meaning of tusi refers to the line patterns on a Samoan siapo. Because of foreign influence, tusi now means to write, a letter, and a book. The lexical evolution of the word tupe is mentioned above. The hybrid and neologism structures are summarised in Table 23 as follows:

Table 23:

Hybrid and Neologism Lexical Constructions in the Gagana Sāmoa

\begin{tabular}{|c|c|c|}
\hline $\begin{array}{c}\text { Lexical } \\
\text { Construction }\end{array}$ & Hybrids & Neologisms \\
\hline 1 & existing word + a loanword & loanword + loanword \\
\hline 2 & existing word + semantic loan & loanword + semantic loan \\
\hline 3 & N/A & $\begin{array}{c}\text { semantic loan + semantic } \\
\text { loan }\end{array}$ \\
\hline
\end{tabular}

The order of existing word/loanword/semantic loan in Table 23 is not fixed. The type falaoa mata is an example hybrid construction 1 but has a loanword (falaoa) preceding the existing word (mata-meaning raw or uncooked).

The following (Table 24) provides examples for each LOLC category. The idea is to demonstrate through types how foreign types appear and have been integrated into the gagana. 
Table 24:

Lexical Outcomes of Language Contact Types

LEXICAL OUTCOMES OF LANGUAGE CONTACT

\begin{tabular}{|c|c|c|c|c|c|c|c|c|c|c|c|c|}
\hline \multicolumn{4}{|c|}{ LOANWORDS } & \multicolumn{4}{|c|}{ SEMANTIC LOANS } & \multicolumn{5}{|c|}{ LOAN TRANSLATIONS } \\
\hline $\begin{array}{c}\text { PROPER } \\
\text { NOUNS }\end{array}$ & MEANING & $G \begin{array}{c}\text { ALL OTHER } \\
\text { NOUNS }\end{array}$ & MEANING & $\begin{array}{c}\text { PROPER } \\
\text { NOUNS }\end{array}$ & MEANING & $\begin{array}{c}\text { ALL OTHER } \\
\text { NOUNS }\end{array}$ & MEANING & $\begin{array}{l}\text { PROPER } \\
\text { NOUNS }\end{array}$ & MEANING & \multicolumn{2}{|c|}{$\begin{array}{c}\text { ALL } \\
\text { OTHER } \\
\text { NOUNS }\end{array}$} & MEANING \\
\hline 'Aferika & Africa & ‘āgelu & angel & Ali ${ }^{\circ} i$ & Christian deity & fa 'ailoga & qualification & Agaga $\mathrm{Pa}$ 'ia & Holy spirit & \multicolumn{2}{|c|}{ ala leo } & $\begin{array}{c}\text { radio } \\
\text { frequency }\end{array}$ \\
\hline 'Agelikana & Anglican & 'eletise & electricity & Atua & Christian deity & lāuga & sermon & Aso Lua & Tuesday & \multicolumn{2}{|c|}{ ali ‘i tōfia } & $\begin{array}{c}\text { Government } \\
\text { official }\end{array}$ \\
\hline 'Ana & Anna & falaoa & flour & Matai & Christian deity & mālō & government & Tausi Mavaega & Trust & \multicolumn{2}{|c|}{ faiā 'oga } & Teacher \\
\hline 'Ētena & Eden & 'imeli & email & Fa'aola & Jesus & lagi & heaven & $\begin{array}{l}\text { Fa 'alāpotopotog } \\
\text { a Va 'a 'o Sāmoa }\end{array}$ & $\begin{array}{c}\text { Sāmoa } \\
\text { Shipping } \\
\text { Corporation }\end{array}$ & \multicolumn{2}{|c|}{ faipule } & District mayor \\
\hline 'Europa & Europe & kanala & canal & Afioga & Bible & fa 'avae & constitution & Tama ita 'i Sā & Catholic nun & \multicolumn{2}{|c|}{ failautusi } & secretary \\
\hline \multicolumn{13}{|c|}{ LEXICAL OUTCOMES OF LANGUAGE CONTACT } \\
\hline \multicolumn{6}{|c|}{ HYBRIDS } & \multicolumn{7}{|c|}{ NEOLOGISMS } \\
\hline \multicolumn{2}{|c|}{ PROPER NOUNS } & MEANING & \multicolumn{2}{|c|}{ ALL OTHER NOUNS } & MEANING & \multicolumn{2}{|c|}{ PROPER NOUNS } & MEANING & \multicolumn{2}{|c|}{$\begin{array}{c}\text { ALL OTHER } \\
\text { NOUNS }\end{array}$} & & MEANING \\
\hline \multicolumn{2}{|c|}{ ‘Amerika Sāmoa } & American Sāmoa & \multicolumn{2}{|c|}{ ala leitiō } & radio station & \multicolumn{2}{|c|}{ Lotu Luteru } & Bretheren Church & \multicolumn{2}{|c|}{ tupe totogi } & & fees \\
\hline \multicolumn{2}{|c|}{ Aso Faraile } & Friday & \multicolumn{2}{|c|}{ fala Saina } & Chinese mat & \multicolumn{2}{|c|}{ Minisitā 'o le Kapeneta } & Cabinet Minister & tupe totc & & & toney exchange \\
\hline Atu $\mathrm{K}$ & & Cook Islands & manu 1 & ālagi & cow & 'Ofisa Ko & lesina & $\begin{array}{c}\text { Office of the } \\
\text { Commissioner }\end{array}$ & moli ui & & & electric torch \\
\hline Lotu $\mathrm{T}$ & naiti & White Sunday & fale & & shop & 'Ofisa 'o & Tiute & Customs Office & fa 'aipoipog. & ario & & vedding jubilee \\
\hline Tusi $\mathrm{F}$ & & Holy Bible & lau & & page & 'Ofisa V & iffetū & Observatory & maketi tau & & & market shares \\
\hline
\end{tabular}




\subsection{2) Some thoughts on LOLC}

The integration of foreign types into the gagana have developed under loanwords, semantic loans, loan translations, hybrids and neologisms. Out of the five, loanwords are the most dominant (see Table 24), and indicates the tendency for foreign types to be phonologically integrated. Yet while the integration and use of loanwords can lead to the decrease in use of existing words, the increase of loan translations and hybrids from 1977-2014, is a positive indicator for the revival and maintenance of the gagana. This is because all loan translations are formed using indigenous words. The increase in hybrid and loan translation coinage is a direct outcome of national and church sovereignty where language policies have since been regulated locally. But, as has been suggested earlier, there is a long way to go towards gaining proper self-determination over gagana development. Proper self-determination here refers to the need to be able to have autonomy over the development and implementation of a standardised orthography for writing, teaching and learning the gagana Sāmoa. This is ever more important in language learning, particularly in diasporic settings such as New Zealand, where the teaching of the gagana can vary in education, government and church settings. Apart from these preliminary observations, there are several other crucial points to be made about LOLC.

Based on this research, foreign types in the gagana show that external forces, such as the influence of religious and political ideologies, rather than internal forces, such as grammatical change, are responsible for all lexical changes in the gagana. Because it was English speaking missionaries and the English-speaking New Zealand administration who had prolonged stays in Sāmoa, and because of the ongoing ties between Sāmoa and New Zealand (e.g. diasporic population), the majority of foreign types in Samoan have English origins. This comes as no surprise.

Foreign types that were identified as a result of external influences indicate that the gagana is a language that has always borrowed from elsewhere. Pre-western contacts with neighbouring Pacific peoples, for instance, resulted in the 'sharing' of languages and cultures. This is reflected in types such as lotu (religion). When foreigners arrived, they deemed many indigenous words (and customs) unfit for the religion and politics they had brought. For that reason, foreigners prescribed new types where in some cases words were adopted from other Pacific languages, such as fa 'aipoipoga (Tahitian word for wedding) and pulela' $a$ (Tahitian 
word for church but used by Samoans to mean church altar), while in other cases, were introduced using the various LOLC lexical processes.

The borrowing characteristic of the gagana has ensured that the gagana has a sizeable body of loanwords from English. The influence of English on the gagana exists in meaning, rather than in form (orthography). Take for instance the loanword 'eletise (see Table 24). 'Eletise is technically an English word, except it has taken Samoan orthography. Interestingly, and as the example of 'eletise demonstrates, even for monolingual speakers of Samoan it could be assumed that they may have a passive knowledge of some English words. Yet because these loanwords have been well-integrated into Samoan, possibly their origin is hidden. Consider the compound word fale 'eletise (electrical house). Here fale, an indigenous word, is used with 'eletise (and also with many other loanwords) to form a very Samoan hybrid.

The presence of English words in the gagana can be viewed differently depending on the perspective taken. Of interest here are two perspectives, that contradict, however. The two perspectives are (1) Pacific Studies and (2) Linguistics. The Pacific Studies standpoint here refers to the idea that we can use Pacific Studies as a means through which we can explore language in ways where we acknowledge both colonial influences, indigneous agency and a collaboration of both. From a Pacific Studies standpoint, therefore, the influence of English becomes a dangerous tool of colonialism. The influence of English was mentioned in the Literature Review as being a trigger for language shift, language loss and the possibility of language death. However, we can also think about the influence of English in another vein. On closer inspection, particularly when reflecting on the high ratio of phonologically integrated loanwords in the gagana, we can view this in two ways: (1) that the high frequency of loanwords can be interpreted as a form of agency and resistance to change and (2) that the capacity of the gagana to phonologically integrate words acts as a medium that ensures that the foreignness of new words are maintained through sound ${ }^{37}$. From a Linguistics perspective, however, while language shift, loss and even death are valid, what

\footnotetext{
${ }^{37}$ This point was brought to my attention in my oral examination were one of my examiners, Dr. Emalani Case, discussed a conversation she had with a mānaleo (a native Hawaiian speaker). In their conversation about foreign words, the mānaleo advised to her that she not use "kula nui" for university, but to use "uniwerki" instead. By using the term uniwerki, the foreignness of the concept of university is maintained, as opposed to finding existing words to accommodate its meaning.
} 
we also see is a language responding to external changes. Also mentioned in the Literature Review is the idea that language change can either contract and expand a language. These concerns were voiced by some of the insider informants who talked about using native models for new coinings.

My final point about LOLC categories is connected to my points about gagana maintenance and lexical indigenisation. The foreign types in this research point to the notion that regardless of LOLC category, all foreign types contribute to the contraction and expansion (see Macpherson 2010) of the gagana. The theoretical point here, of course, is whether and to what extent that contraction and expansion has been controlled or is controllable. To some extent, the contraction and expansion of the gagana has been controlled by the missionaries, the administrations and now the independent Samoan government. As a result, there needs to be better or more informed policies and regulatory systems around language maintenance and development. This needs to be government led and inclusive of the church bodies. What this does is provides a platform to ensure a collective push for a self-determined language that aligns with the aspirational, empowering and decolonial ways desired by Pacific Studies activist scholars like Teaiwa.

\section{4) LĀUGA FA'AMATAI AND LĀUGA FA'ALELOTU: An Analysis}

This section is a synopsis of how foreign types have influenced or changed lâuga fa 'amatai and lāuga fa' alelotu over time. The following discussion is a break-down of the similarities and differences identified in the fa 'alelotu and fa 'amatai discourses for each indicator year.

1906: Sulu: The majority of foreign types in 1906 are place names and are sourced from the Bible, which was an influential medium for religious conversion (see Section 13-Chapter Two). As a result, foreign types in Sulu 1906 are more global, and evident with a high number of Biblical place names. This is not the case in Sāvali 1906 where proper nouns were references to Germany only.

Sāvali: Because 1906 marks only six years after the arrival of the German administration in Sāmoa, the development of a government discourse was only beginning. As a result, and from a comparison of the two discourses during 1906, two significant lexicalprocesses eventuated. 
1. Firstly, there is lexical evidence to suggest that the fa 'amatai discourse in government borrowed foreign types from the more established fa'alelotu discourse. An example of this are the types failautusi (church secretary), fōma ' $i$ (medical doctor) and tusi (book), which were used in Sāvali 1906 for government roles. To expand, the type tusi has been used to coin government documents such as tusi tagi (letter of appeal) and tusi tofiga (letter of appointment). In addition, types such as su'ega (exam), fa'aipoipo and ali ' $i$ have been adopted from the religious discourse to reference government $s u$ ' $e g a$, fa 'aipoipoga ario (wedding jubilee) which was used in 1906 to symbolise the Kaiser's wedding jubilee and ali 'i sili (Kaiser) and ali'i tôfia (government official) have been adopted from the religious discourse as the word for exams in government schools.

2. The second lexical process transpired when borrowing from the religious discourse was not possible due to an absence of equivalent types. As a result, new coinages, particularly to do with social culture, were coined in the government discourse under loan translations. Some examples include ali ' $i$ sili (referring to the Kaiser) and ali 'i tôfia (government official).

The notable difference between $f a$ 'alelotu and fa 'amatai discourses displayed by foreign types in 1906 is the clear indication of the former being considerably more prevalent than the latter. Foreign types in Sulu 1906 addressed religion, spirituality, physical possessions and education. As a result, foreign types in the fa 'alelotu discourse were appropriated into the fa' amatai discourse. This was perhaps because of missionary control and influence over the writing process, and, more importantly, the printing and publication of the language in widely accessible texts. In education, for instance, the missionaries, alongside Samoan clergy, provided both non-secular and secular curricula to most age groups, particularly youth. Another key difference between fa 'alelotu and fa 'amatai discourses was an absence of any government types in Sulu in 1906. This is due to a specific central government discourse being in its infancy stages of lexical development. Finally, German language influence over government rather than religious affairs is highlighted in its use in the Sāvali and absence in Sulu. 
1944: Sulu: Only two foreign types gauged to have originated from government are mentioned in Sulu 1944. These are 'au faigaluega (employees) and fale 'auupega (weapons store). There is a high possibility that this indicates the slow evolution of a distinct fa'amatai discourse in public government written discourse and also points to a continued appropriation of fa'alelotu types by government.

An interesting observation is that the fa' alelotu discourse has become localised with little mention of foreign places. This is most probably because the Bible was well-established by this point.

Sāvali: There are four significant points regarding foreign types in Sāvali 1944 and 1906.

1. Firstly, the fa 'amatai discourses was developing, through the coining of new types, at a rapid rate. New types such as Ulu (Head of Department) and Pule (school principal) highlight the swift establishment of administration sectors in both government and education. Other types include komesina (commissioner), minisitā (cabinet minister), palemia (prime minister), komisi (commission), komiti (committee), uaealesi (wireless), fai-tūlāfono (law maker), matāgaluega (government department), kōvana (governor) and 'Ofisa Vā'aifetū (observatory).

2. Secondly, German types were disused by 1944 which resulted from the forced withdrawal of the German administration in 1914. No German types, such as kaisa (kaiser), kaisalika (imperial government) and kaisalina (Kaiser's wife), for instance, re-appear in later indicator years.

3. Thirdly, the national influence of government was unfolding as religious events, such as tusigāigoa (church fundraising), were being advertised in Sāvali, showing an integration of politics and religion. In Section 7.4 of Chapter Five, it was noted that the type tusigāigoa was the most frequently used type with 89 tokens. 
4. Finally, foreign types in the fa 'amatai discourse shifted in 1944 to have a more international scope with the increase in types such as 'Amerika (America) and Saina (China) were used.

Perhaps one of the main distinction in 1944 between fa' 'alelotu and fa' amatai was that the vocabulary was context-specific, respectively. Foreign types in Sāvali, for instance, continued to address local development while foreign types in Sulu remained Biblically related.

1977: Sulu: Foreign types speak clearly to two significant points about fa'alelotu and fa' 'amatai discourses in 1977.

1. Foreign types in the fa 'amatai and government discourse began to pervade the religious vocabulary.

2. The government discourse became a well-developed lexicon.

Government types had an increased presence in the fa 'alelotu discourse. In fact, and unlike 1944 where foreign types indicated the separation between secular and non-secular words, the fa 'alelotu discourse began to expand and consisted of types to do with entrepreneurship (e.g. pisinisi-business) finance (maketimarket shares and totogi-wages) and technology (uaealesi-wireless telegraph).

Sāvali: The government discourse really soared in 1977. It is mentioned in Section 11.9 of Chapter Five how an influx of foreign types which were coined as a result of Samoa's commitment to domestic and regional politics and development. This is also supported in Table 25 where loan translations and hybrid coinages surged in 1977, and as will be shown later, intensified in 2014. As a result, the government discourse developed into a lexicon that was both locally and internationally relevant. The language aligned with many local developments such as temokarasi (democracy), taupulega Mālō 'Aufa'atasi (Commonwealth), polōkalame atina'e (development programmes), va'alele (aircraft), fa'amasinoga (court hearing), fa'alāpotopotoga tau a'oa'oga ma saienisi (Ministry of Education and Science), aiā tatau (human rights) and lāfoga (taxes). All these types really transformed Samoan's thinking around government discourses and initiated the official arrival of a new form of authority to challenge the authority of the church or religious or spiritual power. 
It was in this indicator year that the surge of foreign types in fa 'amatai discourse imposed its influence. In contrasting fashion, the fa'alelotu discourse was stabilising while the fa 'amatai discourse expanded. This extension of the fa 'amatai discourse in government indicates how language is influential in announcing and establishing social and legal authority. It also shows how language can play a leading role in challenging and shifting social (church) authority in Sāmoa.

2014: Sulu: There are two significant points about the religious discourse in 2014. Firstly, foreign types speak to the fa' alelotu discourse at the height of government influence. Types such as 'auala fa'ale 'äiga (Family Systems Theory), 'auala Fa'atalavai (Dispensary Approach), 'Auala Tu'usa'o (Directive Approach), Fa'alāpotopotoga Tüma'oti (National Government Organisations), sikolasipi (scholarship), penisione (pension) and fömeni (foreman), for instance, are being used in the fa 'alelotu discourse and this demonstrates a somewhat imitation-like approach by the church of government-led developments.

Sāvali: By 2014, an even greater number of foreign types were introduced in fa' amatai discourse. Foreign types are so varied it demonstrates the multi-layered and bustling dimensions of social interactions, particularly in government. The type fa'alapotopotoga (used to mean government ministry), for instance, is widely used to denote the magnitude of government sectors introduced since independence. Some examples include Fa'alāpotopotoga Tūma'oti a le Mālō (government sector), Fa'alāpotopotoga a Leipa a le Lalolagi (International Labour Organisation), and Fa 'alāpotopotoga 'o 'Ele 'ele a Sāmoa (Sāmoa Land Corporation).

Foreign types also show how the gagana has changed in the fa 'amatai discourse in government since 1906, where religious types were being borrowed to make sense of new ideologies, to one where new types are being coined and subsequently become distinctly government related because of the functions and aims of central government.

Since 1977, the fa'alelotu and fa'amatai discourses took two distinct developments. On the one hand, the religious discourse is stablising while on the other, the government discourse is evolving. 


\section{5) CONCLUSION}

This empirical study has yielded new insights into the ways the gagana in the two lâuga discourses fa' alelotu and fa 'amatai has changed over time. As a result of the findings, this discussion contributes to the existing literature and knowledge about gagana change in the following ways.

Firstly, this empirical study provides a comparative and inclusive examination of foreign types generated from church and government as the two main institutions which have driven ideological, and thus lexical, change in Sāmoa. The latter has received little or no attention in the current literature.

Secondly, there is empirical evidence to suggest that while the fa 'alelotu discourse has been the main medium of transformation of the gagana since conversion in 1830, and often functioning as the etymological source in the development of a fa'amatai government discourse, the influence of the fa'amatai discourse in government has since eclipsed the fa 'alelotu discourse in terms of influence on gagana changes. While there are various factors that contribute to this ascendancy, such as independence and local development, another factor may be the fact that Christianity in Sāmoa is relatively insular. In contrast, the government sector aims are deliberately expansive, and thus the vocabularies used, is part of a wider network of international politics. It is for this reason that, I argue, the fa'amatai discourse (discourse of central state government) will increase its influence over the fa 'alelotu discourse (religious and Church-oriented discourses) and be at the forefront of gagana change in the future. While this does seem to point to an increasingly secularised gagana, without further deliberate study of the way in which indigenisation of gagana has operated over time an interdisciplinary address of this question will have to wait.

While the fa'amatai (through central government discourses) is predicted to be the main influence on gagana change in the future, it will do so through a process outlined by the five LOLC. This empirical study has shown that the gagana has integrated foreign types under five LOLC categories of loanwords, semantic loans, loan translations, hybrids and neologisms over a considerable amount of time. A closer examination of the LOLC has yielded new insights about the gagana. Firstly, its amalgamated make-up creates bilingualism and a passive English vocabulary, particularly in loan translation and hybrid constructions. Secondly is the capacity of the gagana to indigenise foreign types. This lexical capacity has become a safeguard from 
the creation of a Samoan-pidgin and is considered central for the self-determined maintenance of Samoan identity.

The next chapter (Chapter Seven) addresses how the research findings in Chapters Four and Five and the discussions herein (Chapter Six) provide answers for the three research questions identified in Chapter Two. 


\title{
CHAPTER SEVEN
}

\author{
Conclusion
}

\section{1) INTRODUCTION}

As a thesis situated in the academic contours of Pacific Studies, this study has been motivated by the need for more Pacific Studies research, in this case about gagana, that are attentive to the interdisciplinary, indigeneity and comparativity prescriptions proposed by Teaiwa (2009). In addition, this thesis has also been motivated by the need for research about the gagana that combines lexical and descriptive analysis through systematic and empirical research (see Chapter Two).

Through the use of the fa 'afaletui and corpus methodologies, the observational and empirical findings in Chapters Four and Five, respectively, have yielded new insights into the processes of gagana change over a 100+ year period (1906-2014). With these in mind, the aim of this chapter is to provide responses to the three research questions outlined in Chapter Two. To revisit, these are:

1. What can a diachronic analysis of the lexicons of lāuga fa 'amatai (discourses of central government) and lāuga fa'alelotu (religious and Church-oriented discourses) tell us about language change in gagana Sāmoa since the arrival of the missionaries in 1830 ?

2. What has been the nature of language contact between läuga fa 'amatai and lāuga fa'alelotu?

3. To what extent can changes in the gagana Sāmoa be attributed to social change?

This chapter is organised into five sections. The first section (7.2) is comprised of three subsections (7.2.1, 7.2.2 and 7.2.3). Each section responds directly to the respective research questions. After the responses to the research questions, the second section (7.3) discusses the relevance of these findings to Pacific Studies as an academic discipline. Section 7.4 then discusses some of the methodological contributions made through the use of the fa 'afaletui and corpus methodologies, as oral and empirical methods, to Pacific Studies. The research challenges encountered throughout this study are then explored in section 7.5. This is followed 
by a review of the research limitations and future research in section 7.6. The chapter is concluded with some final remarks in section 7.7.

\section{2) RESPONSES TO THE RESEARCH QUESTIONS}

7.2.1) What can a diachronic analysis of the lexicons of lāuga fa' amatai (central government discourses) and lāuga fa'alelotu (religious and Church-oriented discourses) tell us about language change in gagana Sämoa since the arrival of the missionaries in $1830 ?$

The discourses of lāuga fa 'amatai and lāuga fa' alelotu were used in this thesis to refer to the discourses used in central government and church. As a result, a diachronic analysis of lāuga fa' 'amatai and lāuga fa'alelotu has revealed some significant points about language change in the gagana Sāmoa.

The first point implies that for major changes to a language to occur, significant social changes need to take place. For Samoans, this came in the form of the missionaries, government and diasporic movements to metropolitan centres. The arrival of the missionaries, for instance, replaced Samoa's indigenous religion and initiated substantial changes to the gagana. It is important to note here that Samoa's conversion to Christianity has not been a complete process. There are, for instance, traces of Samoa's indigneous religion in the church today. Take for instance the notion of tapuā'iga (worship in silence). The notion of tapuā'iga is very much part of cultural practices, even pre-Christian practices that have been maintained by some villages today. Silent worshipping has survived societal changes is very much central in Samoan church services. German withdrawal resulted in the dismantling of German administration systems by the NZA and the subsequent demise of any effects of the German language on the vernacular. English, which was the language of the missions, and also the language of the NZA, therefore, was endorsed by both the Church and government. Thereafter, the mandate period and national independence resulted in the creation of a local government discourse based on foreign systems. Furthermore, the diasporic movement of Samoans away from the homeland was another major social shift which further mobilised contact between the gagana and the English language. The diasporic movements of Samoans away from the homeland have contributed immensely to changes in the gagana. One of the main changes that I believe has resulted 
from population movements is the creation of setting-specific words. In my teaching of the gagana at Victoria University of Wellington, for instance, I have observed that the word faiā'oga, which means teacher and is largely used to refer to any type of teacher, has become specialised in Sāmoa. As an example, a university lecturer in Sāmoa is known as matuaofaiva. In addition, the senior position of Vice-Chancellor is known as Tapa'au. Both words are indigneous and are categorised under semantic loans. This point is connected to the discussion about the differing Pacific Studies and Linguistics perspectives mentioned in Section 6.3.2.

As a result of these significant social shifts, the second point implies that changes to the gagana have evolved within a binary consisting of the gagana and foreign (religious and government) ideologies and languages. This binary has generated a gagana which has mirrored the evolving social environments of the Samoan people (see Section 6.3), both in Sāmoa and abroad. This brings me to my third point.

From a synchronic perspective, foreign types in lāuga fa' 'amatai and lāuga fa' 'alelotu signal changes to the gagana Sāmoa, and these are evidenced by the foreign corpus words found in the indicator years, all of which are reflective of the influence of the major events for each period. As an example, the high percentage of foreign types in $1906(29 \%)$ for both Sulu and Sāvali points to a nation in the midst of German influence, which ended in 1914 with the arrival of the NZA. Lāuga texts in Sāvali 1906 were predominantly administration notices because the newspaper was used by the German administration as a communication medium with the Samoan population. An examination of the 1944 texts reveal that the low percentage of foreign types (7\%) was related more to the limited lāuga texts in both Sāvali (Land and Titles Court cases) and Sulu (church fundraising notices). These texts followed a consistent structure and vocabulary use. The only vocabulary differences between all Land and Titles court case texts, for instance, were plaintiff and defendant names and trial dates. A similar development was found in the Sulu 1944 texts. But in 1977 and 2014, a more varied range of notices and läuga texts resulted in an increase of foreign types (21\% and 39\%, respectively) for these indicator years. In addition, the indicator years 1977 and 2014 were interesting because church foreign types decreased over time while government related foreign types increased. A more detailed discussion of this process is provided in Section 7.2.2 below. What this all means, then, is that through a diachronic examination of lāuga fa 'amatai and läuga fa 'alelotu, changes to the gagana have been 
non-linear. The non-linear evolution of changes to the gagana brings me to my next point.

A diachronic analysis of lāuga fa 'amatai and lāuga fa 'alelotu has revealed that changes to the gagana have been from external influences, such as Samoans social and linguistic contact with Europeans. In other words, because all foreign types have been integrated into the gagana from foreign languages, the gagana, due to its minority status amongst world languages, has had little to no outward influence on English, in particular. However, as was mentioned in the literature review, it is worth revisiting the notion that though the gagana has had no influence on English, it has had some degree of influence on other Pacific languages, such as Tonga, Tūvalu and Tokelau, through early missionary activities in these countries ${ }^{38}$. This could be a result of Samoa's settler colonial status or influence at the time. In addition, it could be because of the close cultural and geographical proximities between these countries. The diachronic analysis of lāuga fa 'amatai and lāuga fa 'alelotu, therefore, indicates that changes to the gagana have been lexical integrations from external languages.

Lastly, if language is a reflection of the social environment, and a marker of social hegemony, and if we are to consider the way the two discourses of fa 'amatai and fa 'alelotu have evolved, changes to the gagana point to a shift in institutional authority from the Church to the State. In recent times, for instance, the political-religious tensions ${ }^{39}$ between the Samoan government and Congregational church in Sāmoa, has caused some interesting moments for reflection on this social hegemony. Since the establishment of the clergy office in Sāmoa, faife 'au were revered individuals. The summoning and charging of faife 'au in a secular central government court indicates a power struggle in Samoa's social hegemony, signalling further changing of times.

Overall, a diachronic examination of the lāuga fa'amatai and lāuga fa'alelotu has revealed that changes to the gagana have transpired due to major social shifts and events, has developed within a complex network consisting of indigenous and foreign ideologies, triggered by external influences and points to a major shift in institutional

\footnotetext{
${ }^{38}$ See Section 2.11 about Foreign Contact in Sāmoa.

${ }^{39}$ The Faife 'au Income Tax Law (FITL) was introduced through fait accompli by the Samoan government for faife ' $a u$ to pay PAYE taxes to the government. The Church, particularly the Congregational Christian Church of Sāmoa denomination, has maintained its rejection of the FITL in its General Assembly meetings. Since 2018, several faife ' $a u$ have been taken to court for not paying taxes. To the general public, the evolving tensions between the government and church is a shift from the normally warm amiable relations.
} 
authority in Sāmoa. The next question examines the nature of language contact between lāuga fa' 'amatai and lāuga fa'alelotu.

7.2.2) What has been the nature of language contact between lāuga fa'amatai and lāuga fa'alelotu?

A response to this research question can be thought of in a number of ways. Firstly, I begin with the premise that both discourses have had some degree of influence on the other both synchronically and diachronically. This has been a result where both were undergoing similar processes of centralisation where the objective was to achieve national consistency in religious and secular governance. Consider, for instance, the breadth of vocabulary sharing between lāuga fa 'amatai and lāuga fa 'alelotu where in 1906, an inter-discourse transfer of words occurred.

The lexicons of lāuga fa 'amatai and làuga fa' 'alelotu in 1906, for instance, signify that existing foreign words in the religious discourse were used to establish the government discourse and borrowed to make sense of newly introduced concepts. Because of this transfer of words, the process initiated the first signs of the precedence and influence of the religious discourse on the government lexicon. At the same time, it created a shared religious and government lexicon. It is important to note, however, that the transfer of words from the religious to the government discourse only transpired when the domains or ideologies were shared in both institutions. For instance, the similarities in interpretations of some aspects of religious status, education, social status, communication and material culture, resulted in the transfer of the words faife 'au (clergy), à'oga (school), failautusi (secretary), tusi (book/letter) and 'ófisa (office), for instance, from the religious to the government discourse.

However, in the instances that the social domains of church and government were dissimilar, borrowing did not eventuate but rather new words were coined for the government discourse. Some examples include the words faipule (district mayor), pulenu ' $u$ (village mayor), komesina (commissioner) and minisitā (cabinet minister).

As the government discourse developed, marked words, such as the ones mentioned above, increased and initiated the development of lexical separation and differentiation between the government and religious discourses. A further development of this trend took place in 1977 and 2014, where the religious discourse began to stabilise as seen in 
the small amount of new foreign types. At the same time, and due to a major increase in foreign types, the government discourse began to evolve extensively.

To make sense of this finding, we can find the answer in the Church's social context. Because the Congregational denomination is an independent church, which makes it locally governed and funded, the non-existence of foreign political and economic influence has contributed to the decrease of foreign types and stabilisation of the religious discourse. In contrast, however, and despite political independence, the Samoan government's reliance on international aid and funding for the development and maintenance of the country's various infrastructures, including Samoa's involvement in the Commonwealth and international politics, ensures that any new ideologies in government will have a very high chance of being introduced into the gagana. The impact of this, of course, is the continued evolution of the government discourse.

Finally, another interesting aspect regarding the nature of language contact between lāuga fa' 'alelotu and lāuga fa' 'amatai worth mentioning is that over time, the interdenominational lexical variations that exist in foreign words in the religious discourse (see Sections 4.2.2 and 5.9.3) are not mirrored by foreign types in the government discourse. The most obvious explanation for this is the fact that unlike government, which can be characterised by the arrival and departure of both the German and NZA's, and which brought a uniform structure and ideology to governance, the missions were multi-denominational which created the existence of inter-denominational lexical variations - all of which, however, were governed by foreign ideologies.

Overall, the nature of language contact between lāuga fa 'amatai and lāuga fa' alelotu has been reciprocal. But in terms of the influence between the two discourses, lāuga fa 'amatai (government discourse), I argue, has had more influence on lāuga fa' alelotu (religious and Church-oriented discourse).

\subsection{3) To what extent can changes in the gagana Sämoa be attributed to social change?}

All changes to the gagana Sāmoa have been determined by significant social changes. The arrival of the missionaries in 1830 and government administrations in 1900-1914 (German administration) and 1914-1962 (New Zealand administration), respectively, 
created a fused and an ongoing association between Samoan and foreign languages and ideologies. This is none more evident than in the 1,975 foreign types identified under the PNs, PLN, SC, RC, MW, NE and OTH categories in this study. This ongoing association was formalised through an ideological interdependence founded on Samoan culture. Though this is the case, the ascendency of the foreign church and government has overshadowed Samoan ideologies bringing into question the reality of Samoa's control over change in gagana.

But any changes to the vernacular cannot be thought of as a Samoan-specific phenomenon. Though Samoan speakers drive gagana change, it is, however, part of a much wider and more global network of social contact that evolved from the political, religious and economic agendas of global powers.

Today, this global network continues to broaden its influence on languages everywhere and particularly minority languages, such as the gagana and Pacific languages in general, through the advancement of scientific knowledge, particularly in the areas of technology and infrastructure. An example of the influence of this global network on the gagana is the all-embracing emergence of online contact made possible through social media. This forum of technological correspondence has triggered the creation of an online orthography characterised mainly by code-switching and shorthand. So while significant changes to the gagana have transpired within the two eras of pre- and postWestern contact, the emergence of an online form of contact has created not only a reconfiguration of social contact, but also the creation of a new medium for gagana change.

Overall, it is fair to say that changes to the gagana have eventuated within a complex and global network of social shifts. With social changes taking place at a rapid rate, further changes to the gagana becomes inevitable.

\section{3) RELEVANCE TO PACIFIC STUDIES}

What, then, is the relevance of the responses to the research questions and conclusions drawn from this research to Pacific Studies? There are three. Firstly, the responses and conclusions highlight the layered complexities of political, social, religious and economic impacts on Samoan language change. Secondly, the findings indicate a need to look more carefully into 
how understanding language change can assist in the maintaining of minority indigenous languages like Samoan in self-determination projects. Lastly, methodologically speaking, the findings demonstrates value in adopting an approach to Pacific research that draws on the strengths of interdisciplinarity, comparativity and indigeneity, through the use of the fa 'afaletui and corpus methodologies, an engagement with both Pacific Studies and linguistic frameworks and tools of analysis, both of which have contributed to the coming together of my diachronic and synchronic analyses. Lastly, the key articulation about Pacific Studies projects that adhere to the interdisciplinary, comparative and indigeneous views mentioned above is the idea that they should not be ethnocentric or nationalistic. What we find in this study of the gagana is the acknowledgement of many important aspects. These include the differences and similarities to other Pacific languages. Equally important is highlighting that changes to the gagana, as with all languages, is the product of many social factors. Lastly, by acknowledging that this project is not ethnocentric or nationalistic brings forth the idea that we share a Pacific geneaology, heritage and origin. All this opens the way for more critical and open discussions about the relationship between Pacific languages and societal changes, and the influences of one over the other.

While this discussion has largely been about the corpus, the next Section examines the methodological contributions that the fa'afaletui, as a Pacific methodology, has had on this study.

\section{4) METHODOLOGICAL ADVANTAGES OF $F A^{`} A F A L E T U I$ AND CORPUS}

Before a discussion of the contributions of the fa 'afaletui on this research, a commentary on the benefits of the combined application of both the fa 'afaletui and corpus methodologies for Pacific Studies and corpus studies in general is useful at this point.

The use of the fa 'afaletui and corpus methodologies in this study has provided an alternative to the polarising contours of Pacific and Corpus studies research that prioritise, on the one hand, qualitative-specific analyses, while on the other hand, a predominantly empirical and quantitative premise of corpus studies.

Very easily, the inclination to prioritise oral perspectives in Pacific-related research, which have emerged from calls to decolonise the academy, which lead to the development of indigenous research methodologies, can often result in the disregard of the merits that empirical 
analyses can provide, a point Teaiwa (2010, p. 116 \& 117) addresses when outlining her concern about Wesley-Smith's empowerment rationale for Pacific Studies. She states:

"...my concern here is with the empowerment rationale. Wesley-Smith describes how the empowerment rationale's indigenizing agendas can take a number of forms...he identifies...first, indigenous scholars simply acquire competence in the tools of Western social science; [and] second, indigenous scholars reject the values and methodology of Western social science...these indigenizing agendas seem to be circulating more widely within the Pacific academies...Indigenous scholars based within traditional and established disciplines acquire competence in the tools of Western social science, while in the interdisciplinary realm of Pacific Studies — or, more accurately, in practices that claim to be Pacific Studies — we increasingly find that indigenous scholars are rejecting the values and methodology of Western social science...I think there should always be space for experimental forms of representation, [as a result] I am not yet prepared to endorse a single "authentic" form for Pacific Studies scholarship."

For Pacific Studies research to be interdisciplinary, argues Teaiwa, empowering Pacific people's voices through Pacific methodologies is crucial, however, it should not be at the expense or neglect of the advantages of mainstream methodologies. Nor the other way around. Thus, the disregard of oral perspectives in corpus-based studies has largely ignored the value that oral perspectives can provide empirical based research. This neglects, it seems, the emphasis in linguistics literature about the significance of speech communities to the evolution of languages. To highlight the methodological advantages of using qualitative and empirical methodologies and analyses in research, I discuss briefly how this has transpired in this research.

\subsubsection{Methodological advantages of fa' afaletui}

In this study, the fa' afaletui has enriched the corpus in the following ways. Firstly, the fa'afaletui provides a conceptualisation from the views of representatives of the speech community regarding changes to the gagana. Secondly, the inclusion of the perceptions of insider informants did provide information that would otherwise have been difficult for me to identify alone or through the literature. The perceptions, for instance, of insider informants about gagana standardisation, is an example. Information regarding the inter-denominational rivalries that were provided in the fa' afaletui sessions magnified the denominational and lexical 
type variations that emerged throughout the corpus, is another example. The orthography differences in proper nouns such as Pêtelo (Congregational) and Pèteru (Catholic) and the senior clergy positions of Toeā ina (Congregational), Sea (Methodist) and Pātele (Catholic), highlight this point. Thirdly, the combined use of the fa'afaletui and corpus offers some bridging of the methodological divide between written and oral discourses.

In addition, one of the main themes outlined in Chapter Six was how the gagana changed over time, in particular how the influence of the religious discourse on gagana change has declined over time and how the government discourse has taken ascendency. This theme was enhanced by the fa'afaletui sessions through insider informant perceptions about the influence of government on language use, particuarly in the domain of education (see Section 4.2.2).

In its own unique way, the corpus complemented fa'afaletui through the provision of an advanced and analytical analysis of the gagana. As is evident in this study, therefore, the implementation of the fa' afaletui and corpus methodologies has endorsed the advantages of joint qualitative and empirical analyses to research in the field of Pacific Studies and corpus studies. But despite the contributions of the corpus and the fa 'afaletui, this study was not without its challenges.

\section{5) RESEARCH CHALLENGES}

There were several challenging aspects encountered during this study. The first challenge was finding texts that aligned with years of significant social change in Sāmoa. The years 1830 (missionary arrival), 1900 (German occupation), 1914 (NZA occupation), and 1962 (Samoan Independence), for instance, brought significant social change in Sāmoa. Unfortunately, the unavailability of texts for either of these years made any preconcieved preferences unfeasible. As a case in point, the 1836 and first ever publication of Sulu, which is shelved at the NZNL, for instance, has no equivalent in government Sāvali publications due to the later arrival of administrations in 1900. As it is mentioned in Section 3.4.1, the indicator years (1906, 1944, 1977 and 2014), therefore, were determined based on the availability of Sulu and Sāvali texts.

In a related vein, the sourcing of texts was another challenge due to the non-existence of a single storage location (see Section 3.5.3 - Table Four). Texts, for example, were sourced from various locations such as NUS, MTC, NZNL and NMPL libraries, the CCCS Book Shop, Sulu 
Office, Sāvali Office and LTC. For some of these locations, text accessibility took some time, and usually required verbal permission supported by a letter of request.

In addition, one of the most challenging tasks in this study was the manual construction of the foreign type word list. For all 1,975 foreign types, for instance, the recording of each type's page numbers, tokens and collocations were all incorporated into the 274 page word list. Despite these challenges, however, the research process provided valuable experience towards the identification and accessibility of texts and the construction of word lists. In the next Section, the research limitations and future research possibilities are provided.

Finally, there were also philosophical and methodological challenges. The combining of Pacific Studies and Corpus studies methodologies of fa 'afaletui and corpus, for instance, were not only methodologically different, but had philosophical differences also. Another challenge was to ensure that though there is a dominant focus on linguistic frameworks, such as the incorporation of corpus and LOLC, that the Pacific Studies voice was prominent and heard throughout. There were epistemological challenges, also. The describing and defining of the central government discourse as lāuga fa'amatai and church newspaper discourse as lāuga fa' 'alelotu, for instance, are some examples. The idea here is not to provide solutions, but to highlight that challenges exist when combining two different methodologies in research.

\section{6) RESEARCH LIMITATIONS AND FUTURE RESEARCH}

As is the case with academic research, it is crucial to narrow the scope of research for a feasible and achievable project. This study is no different. In this section, therefore, I identify the limitations of this research and provide avenues for future research.

A range of areas have been identified as limitations for this research. The first area is the focus on the discourse of lāuga. The decision to focus on lāuga was that it was a discourse that represented the transition from oral to written Samoan. In addition, lāuga was identified to be uniquely situated at the center of church and government influence. As is mentioned elsewhere in this thesis, this examination of lāuga has yielded new insights about changes to the written gagana. But there are other discourses in the gagana that can be examined for future research and that would add valuable contributions to the developing literature on gagana change. These discourses include, but are not limited to, pese (song), fāgogo (storytelling) and alagā 'upu and muāgagana (metaphorical expressions). Pese is an interesting discourse due to the introduction 
of pese lotu (hymns) and the abolition of some traditional song forms, such as tini, by the missions (see Section 2.13).

Another area of examination may include a comparative overview of pese fa 'aleaganu' $u$ (traditional songs) and pese lotu, the first of which was common at Samoan village sporting and cultural festivities. A comparison of pese lotu and fägogo would also be valuable. An important aspect to consider, however, is the limited availability of texts. In Moyle's (2009) work on $f \bar{a} g o g o$, for instance, the majority of the resources that were available were oral recordings. Furthermore, the focus on lāuga is only a snapshot of foreign vocabularies in the gagana. It is without doubt the case that more foreign types can be located in other discourses of the gagana, in the discourses discussed above.

In regards to text, this study has been limited to an examination of Sulu and Sāvali newspapers. The rationale in using these texts was based on their availability and as text representations of church and government. But like the conceputal limitations addressed in the discussion about lāuga, the advantages of extending research to include other newspapers is recommended. To examine other newspaper texts will provide different perspectives and findings about changes in the gagana. Newspapers such as the Sāmoa Observer and Sāmoa Times, for instance, are not confined to church and government per se, but rather have a more comprehensive range of texts that mirror the social diversity of Samoan society.

Like the Sulu and Sāvali, similar benefits of these newspapers are the use of the gagana and publication consistency. The accessibility of online and hard-copies of these texts is also valuable. Other newspapers worth examining include the Samoan Reporter and Samoan Bulletin. These newspapers, however, were printed in English and have been discontinued, but nonetheless, may have some relevance in regards to government and church approaches to language development and planning in Sāmoa during the early 1900s.

Other texts of significance include the Tusi Pa 'ia (Bible), Tusi Fa'alupega (salutation texts), Fa'avae 'o le Mālō Tūto 'atasi 'o Sāmoa (Samoan government constitution), minute 'o fono fa 'apalemene (parliamentary minutes and debates) and tusitusiga (letters). As historical texts, the Tusi Pa 'ia and Tusi Fa'alupega manuscripts are significant texts as these were published by the LMS printing press in Sāmoa. Manuscript revisions, which have been published and disseminated widely, will be significant in looking at more diachronic examinations of the gagana which will provide depth to an otherwise scant literature about text-based changes in the gagana. 
The Fa'avae 'o le Mālō 'o Sāmoa, minute 'o fono fa'apalemene and tusitusiga provide intriguing accounts of the state of the gagana during German and NZA occupation in Sāmoa and the lead-up to Samoan independence. Tusitusiga texts, in particular, are intriguing because of the communicative function these played in liaison between Samoans and the administrations in the mid 1900's. The fact that these letters were handwritten by Samoan leaders, such as Malietoa Tanumafili, provides a raw and unedited version of gagana use. A significant amount of these letters are shelved at the New Zealand National Library (NZNL) in Wellington. But having consulted these letters beforehand, the intermittent writings of these letters is a setback if one of the research pre-requisites is publication regularity. This, of course, has implications for diachronic analysis, but maybe useful for synchronic analyses.

Future studies can also expand on the influences of Christianity by researching the lexical similarities and variations of Samoan church denominations. Like Christianity, there is an opportunity to expand on the influence of government on the gagana through an examination of Samoa's parliamentary meetings. Understanding the full breadth of the gagana's influence on other Polynesian languages, such as Tūvalu and Tokelau (see Jackson \& Jackson 1999) during missionisation, is another avenue of research which will be intriguing towards expanding current knowledge of the influence of missionisation in the region. Future research can also delve into examining whether a New Zealand Samoan variety exists and how similar or different it is to the gagana used in Sāmoa and elsewhere. This will be beneficial towards understanding the influences on speakers who are not fluent in the language but who use a patois to signal cultural identity and which can be used to exclude non-Samoan speakers from discussions. In addition, and as is mentioned in Section 7.2.3 about social media platforms being mediums for changes in the gagana, another avenue for future research can examine the orthography of the gagana on social media forums.

As the church and government, including social media, continues to influence gagana change, there is much to learn about the etymology, orthography, semantics and morphology of the gagana Sāmoa in these domains. More research, for instance, can delve into these areas to develop an understanding of the breadth of lexical connections between the gagana and other Polyneisan languages, particularly Tonga, Fiji, Tūvalu and Tokelau. I conclude this chapter by providing some final remarks in Section 7.6.

\section{7) FINAL REMARKS}


My intrigue with the complexities of how, in what way(s), and to what extent the gagana has changed has come full circle. In more ways than one, this study has triggered a new sense of alofa for and poto about the gagana, as a Samoan-born, matai, ti 'ākono, faife 'au son, faipese, faiā' $\operatorname{og} a$, faiavā, tamā and sogā' imiti based in Wellington, New Zealand. But more questions remain, such as that posed by Macpherson $(2009$, p. 58) when he asks whether a society of some 185,000 people, can hope to resist or even control the global forces of today's world? In light of these questions, including many more, there is much to examine, learn and anticipate about the gagana, as the second most spoken language in Auckland and the third most spoken language in New Zealand. The notion that the gagana, remains a minority language in New Zealand, however, makes it susceptible to language loss and makes its maintenance ever more important. What remains inevitable, however, is the notion that the gagana will continue to change.

I would like to end with the title of this thesis, 'O le li' ili' $i$ mai 'o lisega 'o le fanaa 'e, which refers to the complex (li 'ili 'i) dew (lisega) of approaching dawns ('o le fanaa 'e ). I have used it as a constant reminder of the importance of the gagana to the survival of not only Samoan culture, but Samoan identity and people. It has constantly reminded me of a common Samoan metaphor that reads: a leai se gagana, 'ua leai se aganu'u, a leai se aganu'u, 'ua pō le nu'u, which I translate as: if there is no language, there is no culture, if there is no culture, darkness descends upon the village. Soifua ma 'ia manuia (Good health and blessings)! 


\section{REFERENCES}

Aitchison, J. (2001). Language change: progress or decay? Cambridge. Cambridge University Press.

Akeli, S. (2017). Cleansing Western Sāmoa: Leprosy Control during New Zealand Administration, 1914-1922. The Journal of Pacific History 52(3), p. 360-373.

Allardice, R. W. (2000). A simplified dictionary of modern Samoan. Pasifika Press. Auckland, New Zealand.

Amituana'i-Toloa, M. (2010). To Each a Language: Addressing the challenges of language and cultural loss for Samoans. AlterNative: An International Journal of Indigenous Peoples, 6(2), $79-85$.

Anae, M. (2001). Pasifika education research guidelines: final report. Ministry of Education. Wellington, New Zealand.

Anae, M. (2002). Papālagi Redefined: Toward a New Zealand-Born Samoan Identity. Pacific diaspora: island peoples in the United States and across the Pacific. Paul Spickard, Joanne Rondilla, Debbie Hippolite Wright (Eds). University of Hawai'i Press, Honolulu, p. 87-98.

Anae, M. (Ed.), Tangata 'O Te Moana Nui: the Evolving Identities of Pacific Peoples in Aotearoa/New Zealand (pp. 196-211). Dunmore Press. Palmerston North.

Appel, R., \& Muysken, P. (1987). Language contact and bilingualism. London: Edward Arnold.

Baldauf, R. B. and A. Luke (1990). Language planning and education in Australasia and the South Pacific. Multilingual Matters. Clevedon.

Bauer, L. (2006). Language matters. Houndmills, Basingstoke, Hampshire. New York.

Bauman, R. (1977). Verbal art as performance. Prospect Heights. Waveland Press.

Bellwood, P. (1996). Hierarchy, Founder Ideology and Austronesian Expansion. Origins, Ancestry and Alliance: Explorations in Austronesian Ethnography. J. J. Fox, C. Sather, J. J. Fox and C. Sather (Eds). ANU Press. Canberra, p. 19-34. 
Besnier, N. (1995). Literacy, emotion, and authority: Reading and writing on a Polynesian atoll: Studies and Cultural Foundations of Language No. 16. Cambridge University Press. Great Britain

Biber, D. (1998). Corpus linguistics: investigating language structure and use. Cambridge University Press. New York.

Biewer, C. (2015). South Pacific Englishes: a sociolinguistic and morphosyntactic profile of Fiji English, Samoan English and Cook Islands English. John Benjamins Publishing Company. Amsterdam. Philadelphia.

Boissonnas, V. (2014). Beyond the rim. A comparative study of Kava bowls from Samoa, Tonga and Fiji. Journal of the Polynesian Society, 123(4), 357-382.

Boyd, M. (1968). The Military Administration of Western Sāmoa, 1914-1919, p 148-164.

Boyd, M. (1980). Coping with Samoan Resistance after the 1918 Influenza Epidemic: Colonel Tate's Problems and Perplexities. The Journal of Pacific History, 15(3), 155-174.

Brown, C. and S. Witkowski (1983). Polysemy, lexical change and cultural importance. Man 18(1), p. 72.

Cain, H. (1986). A lexicon of foreign loan-words in the Samoan language. Bohlau, Koln.

Chilisa, B. (2012). Indigenous research methodologies. SAGE Publications. Thousand Oaks, California.

Clark, D. (2010). Patterns of replacement in the Samoan lexicon. A Journey through Austronesian and Papuan linguistic and cultural space in honour of Andrew Pawley. J. Bowden and N. R. Himmelmann (Eds). Pacific Linguistics. Auckland, p. 547-554.

Clery, T. N. (2014). Extending the Talanoa: Weaving Pacific and performative methods for peace research in contemporary Fiji. Talanoa : building a Pasifika research culture. P. Fairbairn-Dunlop and E. Coxon (Eds). Dunmore Publishing. Auckland, New Zealand, p. 105127.

Conde-Silvestre, J. C. (Ed.), The Handbook of Historical Sociolinguistics (pp. 401-421). Malden, MA: Wiley-Blackwell.

Conrad, S. (2012). German colonialism : a short history. Cambridge University Press. New York. 
Cooper, R. L. (1989). Language planning and social change. Cambridge University Press. Cambridge. United Kingdom.

Couper, A. (2009). Sailors and Traders: A Maritime History of the Pacific Peoples. University of Hawaii Press. Honolulu.

Crocombe, R. (1976). The Pacific way : an emerging identity. Lotu Pasifika. Suva, Fiji.

Crocombe, R. G. (2001). The South Pacific. Institute of Pacific Studies, University of the South Pacific. Suva, Fiji

Crowley, T. (2000). The Consequences of Vernacular (Il)literacy in the Pacific. Current Issues in Language Planning 1(3), p. 368-388.

Davidson, J. (2012). Intrusion, integration and innovation on small and not-so-small islands with particular reference to Sāmoa. Archaeol. Oceania 47, p. 1-13.

Davies, J. (1978). A Tahitian and English dictionary : with introductory remarks on the Polynesian language and a short grammar of the Tahitian dialect : with an appendix containing a list offoreign words used in the Tahitian Bible, in commerce, etc., with the sources from whence they have been derived (1st AMS ed.. ed.). New York: AMS Press.

Dazdarevic, S., et al. (2015). Benefits of Corpus-Based Approach to Language Teaching. Balkan Distance Education Network - Baden Newsletter 7.

Denoon, D. and M. Meleiseā (1997). Colonial Administration and the Invention of the Native. The Cambridge History of the Pacific Islanders. University Press. Cambridge, New York, p. 253-258.

Deverson, T. (2000). Handling New Zealand English Lexis. New Zealand English. Victoria University Press. Wellington, p. 23-40.

Downs, E. A. (1949). Everyday Samoan-Samoan grammar elucidated by the use of numerous examples from ordinary conversation in the Samoan language. North Shore Gazette. Devonport, New Zealand.

Drechsel, E. J. (2014). Language contact in the early colonial Pacific: Maritime Polynesian Pidgin before Pidgin English: New York : Cambridge University Press.

Duranti, A. (1983). Samoan speechmaking across social events: One genre in and out of a fono. Language Socialisation. 12(1), p. 1-22. 
Duranti, A. (1990). Code Switching and Conflict Management in Samoan Multiparty Interaction. Pacific Studies 14(1), p. 1.

Duranti, A. (1992a). Heteroglossia in Samoan Oratory. Pacific Studies, 15(4), 155-175.

Duranti, A. (1992b). Language and Bodies in Social Space: Samoan Ceremonial Greetings. American Anthropologist, 94(3), 657-691.

Dutton, T. (1994). Introduction. Language contact and change in the Austronesian world. T. Dutton and D. T. Tryon (Eds). Mouton de Gruyter. Berlin; New York, p. 1-2.

Elbert, S. H. (1953). Internal Relationships of Polynesian Languages and Dialects. Southwestern Journal of Anthropology, 9(2), 147-173.

Ellison, J. W. (1938). Opening and Penetration of Foreign Influence in Sāmoa to 1880. Oregon State College. Corvallis, Oregon.

Executive Council of New Zealand. (1920). The laws of the Territory of Western Sämoa : as established by the Sämoa Constitution Order, 1920, and other Orders in Council of the Executive Council of New Zealand which came into operation on the first day of May, 1920. Wellington, New Zealand.

Fa'alafi, F. T. S. (2005). Carrying the Faith: Samoan Methodism 1828-1928. Piula Theological College. Apia, Sāmoa.

Fairbairn-Dunlop, P. \& Coxon, E. (2014). Talanoa : building a Pasifika research culture. Dunmore Publishing. Auckland, New Zealand.

Fanaafi le Tagaloa, A. (1996). 'O Motugā'afa. Fanaafi le Tagaloa. Apia, Sāmoa.

Field, M. (2006). Black Saturday: New Zealand's Tragic Blunders in Samoa. Auckland: Reed. Fishman, J. A. (1973). Language and nationalism two integrative essays. Rowley, Mass. Newbury House Publishers.

Fishman, J. A. (2006). Do not leave your language alone: the hidden status agendas within corpus planning in language policy. Mahwah, N.J. Lawrence Erlbaum Publishers.

Foster-Cohen, S. H. (2009). Language acquisition. Palgrave Macmillan. Houndmills, Basingstoke, Hampshire, England. 
Freeman, D. (1983). Margaret Mead and Sämoa: the making and unmaking of an anthropological myth. Australian National University Press. Canberra.

Freeman, J. D. (1944). 'O le fale 'o le fe'e. Journal of the Polynesian Society, p. 121-144.

Gegeo, D. W., \& Watson-Gegeo, K. A. (2001). "How We Know": Kwara'ae Rural Villagers Doing Indigenous Epistemology. The Contemporary Pacific, 13(1), 55-88.

Geraghty, P. (1993). Pulotu, Polynesian Homeland. The Journal of the Polynesian Society, 102(4), p. 343-384.

Geraghty, P. (1995). Prehistoric Exchange Between Fiji and Western Polynesia: Some Evidence from Linguistics. Rongorongo Studies: A Forum for Polynesian Philology. Institute of Polynesian Languages and Literatures.

Gilson, R. P. (1970). Sāmoa 1830 to 1900: The Politics of a Multi-Cultural Community. Oxford University Press. London.

Groube, L. (1971). Tonga, Lapita Pottery, and Polynesian Origins. The Journal of the Polynesian Society 80(3), p. 278.

Habinek, T. N. (2004). Ancient rhetoric and oratory. Blackwell PUB. Malden.

Hardwicke, H. (1896). History of Oratory and Orators: A Study of the Influence of Oratory upon Politics and Literature. G. P. Putnam's Sons. New York, London.

Hickey, R. (2001). Language Change. In Verschureren, Jef., Ostman, Jan-Ola., Blommaert, Jan., Bulcaen, \& Chris. (Eds.), Handbook of Pragmatics. Amsterdam: John Benjamins.

Hickey, R. (2010). Contact and Language Shift. In R. Hickey (Ed.), The Handbook of Language Contact (pp. 151-169): Blackwell Publishing Ltd.

Hickey, R. (2012). Internally and externally motivated language change. In C. M. Hernandez, J.

Hollyman, K. J. (1962). The Lizard and the Axe: A Study of the Effects of European Contact on the Indigenous Languages of Polynesia and Island Melanesia. The Journal of the Polynesian Society, 71(3), 310-327.

Holmes, L. D. (1969). Samoan Oratory. The Journal of American Folklore, 82(326), 342-352. 
Horst, C. (1986). A lexicon of foreign loan-words in the Gagana. Kolner ethnologische. Mitteilungen.

Hovdhaugen, E. (1992). Language contact in the Pacific: Samoan influence on Tokelauan. In E. H. Jahr (Ed.), Language contact theoretical and empirical sutdies (pp. 53-69). Berlin; New York: mouton de Gruyter.

Hugh, L. (1978). Church and State in German Sämoa: the Solf-Broyer Dispute, by Hugh Laracy, p 158-167.

Hunkin, A. and J. Meyer (2006). Language and Culture Loss in the Pacific. Pacific futures, M. Powles (Eds). Pandanus Abingdon, Marston distributor. Canberra.

Hunkin, G. (2009). Gagana Sāmoa: A Samoan Language Coursebook. Honolulu: University of Hawai'i Press.

Hunkin-Tuiletufuga, G. (2001). Pasefika Languages and Pasefika Identities: Contemporary and Future Challenges. Tangata 'o te Moana Nui: the Evolving Identities of Pacific Peoples in Aotearoa/New Zealand. C. S. Macpherson, P. Anae, M (Eds). Dunmore Press. Palmerston North, p. 196-211.

Hunkin-Tuiletufuga, G. (2012). To Let Die: The State of the Samoan Language in New Zealand. AlterNative: An International Journal of Indigenous Peoples, 8(2), 203-214.

Hunston, S. (2006). Corpus Linguistics. Elsevier Ltd. Birmingham.

Kalavite, T. (2014). Exploring Pacific-Tongan research approaches. Talanoa: building a Pasifika research culture. P. Fairbairn-Dunlop and E. Coxon (Eds). Dunmore Publishing. Auckland, New Zealand.

Kamu, L. (2008). 'O le aganu'u ma le talalelei. D.L. Kamu. Apia, Sāmoa.

Kaplan, R. B. (2013). Language planning. Applied Research on English Language 2(1), p. 112.

Kauraka, K. (1991). Thinking about Cook Islands native religion. Rarotonga.

Keesing, R. M. (1988). Melanesian Pidgin and the Oceanic substrate. Stanford University Press. Stanford, California.

Kenix, L. J. (2015). You are either with us or with us: Constructing a Samoan national identity through inclusion at the Sāmoa Observer. Journalism 16(4), p. 553-570. 
Koskinen, A. (1968). Kite: Polynesian Insights into Knowledge. Helsinki.

Kramer, A. (1995). The Samoa Islands (Vol. 2). New Zealand: Polynesian Press.

Kruse-Vā'ai, E. (2011). Producing the text of culture : the appropriation of English in contemporary Sāmoa. Le Papaigalagala, National University of Sāmoa. Sāmoa.

Labov, W. (1994). Principles of Linguistic Change Volume 1: Internal Factors: Oxford: Blackwell.

Lāmeta, E. (2005). Language policy: the case of Sāmoa. Directions: Journal of Education Studies 27(1), p. 42-76.

Lang, P. (2002). Race and Realpolitik: the politics of colonisation in German Sämoa. Europaishcer Verlag der Wissenschaften. Frankfurt.

Langacker, R. W. (1967). Language and its Structure: Some Fundamental Linguistic Concepts. Harcourt, Brace \& World, Inc. United States of America.

Lange, R. (2006). Island Ministers: Indigenous Leadership in Nineteenth Century Pacific Islands Christianity. Macmillan Brown Centre for Pacific Studies \& University of Canberra. Christchurch, Canberra.

Lātai, L. (2015). Changing Covenants in Sāmoa? From Brothers and Sisters to Husbands and Wives. Oceania, 85(1), 92-104.

Lauofo, M. \& M. R. Meredith. (2002). Sāmoa: the making of the constitution. Le Papaigalagala, National University of Sāmoa. Sāmoa.

Lesā, F. (2009). The impact of Samoan Christian churches on Samoan language competency and cultural identity. In M. Maaka (Ed.): ProQuest Dissertations Publishing.

Liua'ana, B. F. (1997). Dragons in Little Paradise: Chinese (Mis)-Fortunes in Sāmoa, 19001950. The Journal of Pacific History, 32(1), 29-48.

Lloyd, T. O. (1996). The British Empire, 1558-1995. Oxford University Press. Oxford, United Kingdom. Auckland, New Zealand.

Lynch, J. (1998). Pacific Languages. University of Hawai‘i. Hawai‘i.

Lynch, J., Ross, M., \& Crowley, T. (2002). The Oceanic Languages. Routledge. New York. 
Ma'ia'i, S. (2010). Tusi 'Upu Sāmoa: The Samoan Dictionary of Papāli 'i Dr Semisi Ma 'ia'i. Little Island Press. Grey Lynn. Auckland, New Zealand.

Ma‘ilo, M. (2016). Bible-ing my Samoan. Mosese Ma'ilo. Apia, Sāmoa.

Macalister, J. (2007). Weka or Woodhen? Nativization through lexical choice in New Zealand English. World Englishes 26(4), p. 492-506.

Macpherson, C. (2009). The warm winds of change: globalisation in contemporary Sāmoa. Auckland University Press. Auckland, New Zealand.

Macpherson, C. (2010). Some Social and Economic Consequences of Migration: A Curriculum Paper for Sāmoa. Prepared for UNESCO Social Science Programme.

Macpherson, C. (2010). Some Thoughts on Change in the Samoan Language. A Journey through Austronesian and Papuan Linguistic and Cultural Space: Papers in Honour of Andrew K. Pawley. Bowden, John., Himmelmann et al. Canberra, Pacific Linguistics, p. 591-606.

Māhina, O. (2004). Issues and challenges in Pacific research. Some critical comments. Researching the Pacific and Indigenous Peoples: Issues and perspectives. T. Baba, O. Māhina, N. Williams and U. Babobo-Baba (Eds). Institute of Pacific Studies. Suva.

Malielegaoi, Tuila'epa. S. (2017). Pālemia: Prime Minister Tuila'epa Sa 'ilele Malielegaoi of Sāmoa: a memoir. Victoria University Press. Wellington.

Mallon, S. \& Galliot, S. (2018). Tatau : a history of Samoan tattooing. Wellington, New Zealand: Te Papa Press.

Manu'atū, L. (2000). Tuli Ke Ma'u Hono Ngaahi Malie: Pedgogical possibilities for Tongan students in New Zealand secondary schooling, Unpublished EdD thesis, The University of Auckland, New Zealand.

Maua-Hodges, T. (2000). Ako Pai Ki Aitutaki: Transporting or weaving cultures. Research report of field experiences to the Cook Islands. Wellington College of Education. Wellington, New Zealand.

Mayer, J. (2001). Code -switching in Samoan: T-style and K-style. In A. Schutz (Ed.): ProQuest Dissertations Publishing.

McEnery, A., et al. (2006). Corpus-Based Language Studies: an advanced resource book. Routledge Applied Linguistics, Routledge. 
McEnery, T. and A. Hardie (2011). Corpus Linguistics : Method, Theory and Practice. Cambridge University Press. Cambridge.

McFarland-Tautau, M., \& Hunkin, G. A. (2012). The Orator/`O le Tūlāfale (Review). The Contemporary Pacific, 24(2), 441-446.

McLane, R. (2014). One Disease, One People, Two Histories: Influenza and Quarantine in Sāmoa. Guest Presentation in VASA Seminar Series, Va'aomanū Pasifika, Victoria University of Wellington.

Meleiseā, L. M., Meleiseā, P. S., \& Meleiseā, E. (Eds.). (2012). Samoa's Journey 1962-2012: Aspects of History. Wellington: Victoria University Press.

Meleiseā, M. (1978). Oral Traditions in the Pacific. Preserving Indigenous Cultures: a new role for museums: papers from a regional seminar. Adelaide Festival Centre 10-15 September 1978. Australian Government Publishing Service. Canberra.

Meleiseā, M. (1987). The Making of Modern Sāmoa: Traditional Authority and Colonial Administration in the Modern History of Western Sämoa. Institute of Pacific Studies of the University of the South Pacific. Suva.

Meleiseā, M. (1987a). Lagaga: A Short History of Western Sāmoa. Suva: University of the South Pacific.

Meleiseā, M. (1992). Change and Adaptations in Western Sāmoa. Christchurch, New Zealand: Macmillan Brown Centre for Pacific Studies.

Meleiseā, M., \& Schoeffel, P. (2017). German in Sāmoa. In K. Mühlhahn (Ed.), The Cultural Legacy of German Colonial Rule (pp. 143-165): De Gruyter Oldenbourg.

Meleiseā, M., Meleiseā, P., Va‘ai, I., \& Suafole, I. (2017). New Zealand Sāmoa 1944. In Unknown (pp. 125-146).

Millington, R. (2019). Personal Communication. 29 May, 2019. Victoria University of Wellington. Wellington.

Milner, G. B. (2012). Samoan Dictionary. Auckland New Zealand, Pasifika Press.

Mosel, U. and E. Hovdhaugen (1992). Samoan Reference Grammar. Scandanavian University Press. Oslo. 
Moyle, R. M. (2009). Fāgogo : fables from Sāmoa in Samoan and English / collected, arranged and translated by Richard Moyle. Auckland University Press. Auckland

Muaiava, S. (2011). Fa'atagata 'esea 'i Nu'u 'Ese: Samoan Faife' au Kids as Tagata 'ese and Alo 'o Fa'afeagaiga in New Zealand. (Master of Arts in Pacific Studies), Victoria University of Wellington, Wellington.

Muaiava, S. (2018). Tatau and Alagā'upu: A lineage of charting and continuation. In S. Mallon \& S. Galliot (Eds.), Tatau : a history of Samoan tattooing. Te Papa Press. Wellington. New Zealand.

Muaiava, S., \& Sua'ali'i-Sāuni, T. (2012). The Orator/`O Le Tūlāfale (review). In The Contemporary Pacific, Vol. 24, pp. 438-441).

Muhlhausler, P. (1996). Linguistic Ecology: Language change and linguistic imperialism in the Pacific region. Routledge. London.

Muhlhausler, P. (1990). Reducing Pacific languages to writings. Ideologies of Language. J. Joseph and T. Taylor (Eds). Routledge. London.

Muhlhausler, P. (1987). The politics of small languages in Australia and the Pacific. Language and Communication 7(1), p. 1-24.

Myers, D. (1921). The Mandate System of the League of Nations. The Annals of the American Academy of Political and Social Science, 96, p. 74-77.

Nabobo-Baba, U. (2006). Knowing and learning: an indigenous Fijian approach. Institute of Pacific Studies. Suva.

Narokobi, B. (1981). The Melanesian way. Institute of Papua New Guinea Studies. Boroko. Papua New Guinea.

Neffgen, H. (1918). Grammar and vocabulary of the Samoan language, together with remarks on some of the points of similarity between the Samoan and the Tahitian and Maori languages. London: K. Palu, Trench, Trubner.

Nunes, C. (2006). Samoanising my Fa'apapalagi: The Indigenization of Language in Sämoa. S.I.T Sāmoa. Fall 2006. National University of Sāmoa. Sāmoa.

O'Brien, P. (2007). Tautai: Sāmoa, world history, and the life of Ta'isi O.F. Nelson. Honolulu: University of Hawai'i Press. 
Otsuka, Y. (2005). History of Polynesian Languages. (Ms), Honolulu. Oxford University Press. Parsonson, G. (1967). The Literate Revolution in Polynesia. The Journal of Pacific History 2, p. 39-57.

Pauwels, A. (2016). Language Maintenance and Shift. Cambridge University Press.

Pawley, A. \& R. Green (1973). Dating the Dispersal of the Oceanic Languages. Oceania Linguistics 12(1/2), p.1-67.

Pawley, A. (1966). Polynesian Languages: A Subgrouping Based on Shared Innovations in Morphology. The Journal of the Polynesian Society, 75(1), p. 39-64.

Pawley, A. (2007). Why do Polynesian island groups have one language and Melanesian island groups have many? Patterns of interactions and diversification in the Austronesian colonization of Remote Oceania. Paper presented at the Workshop on Migration, Ile de Proguerolles, France.

Pawley, A., \& Green, R. (1973). Dating the Dispersal of the Oceanic Languages. Oceania Linguistics, 12(1/2), 1-67.

Pawley, A., \& Ross, M. (1995). The Prehistory of Oceanic Languages; A Current View. Canberra: Canberra : Dept. of Anthropology, Australian National University.

Percival, G. S. (2008). 'O le afì tunu a le Tupu. Paradigm Documentaries. Apia, Sāmoa.

Pomeroy, E. S. (1970). Pacific outpost American strategy in Guam and Micronesia. Russell \& Russell. New York.

Pratt, G. (1862). Pratts Grammar Dictionary and Samoan Language. Malua Printing Press. Sāmoa.

Purcell Sjölund, A. (2012). Exploring 'Samoaness' in the Samoan language film The Orator (O Le Tulafale).

Rakuita, T. (2014). And the Word was God: Disentangling Language Games in Oceania. Whispers and vanities: Samoan indigenous knowledge and religion. T. M. Suaali'i-Sāuni, M. A. Wendt, V. Mo'a et al. Huia Publishers. Wellington, p. 159-166.

Rensch, K. (1994). Early European influence on the languages of Polynesia: The Gambier Islands. In T. Dutton \& D. T. Tryon (Eds.), Language Contact and Change in the Austronesian World (pp. 477-495). Berlin: Mouton de Grayter. 
Ritchie, J. (1979). Growing up in Polynesia. Sydney: George Allen \& Unwin Australia.

Salesa, D. (2014). When the Waters Met: Some Shared Histories of Christianity and Ancestral Samoan Spirituality. In T. Suaali'i-Sauni, A. Wendt, V. Mo'a, N. Fuamatu, U. L. Va'ai, R. Whaitiri, \& S. L. Filipo (Eds.), Whispers and Vanities: Samoan Indigenous Knowledge and Religion (pp. 143-158). Wellington, Aotearoa: Huia Publishers.

Salevao, E. (2017). Language and the law: A Samoan case study. Australasian Parliamentary Review, 32(1), 131-152.

Sāmoa Government. (2015). Casino and Gambling Control Act 2015. Accessed from http://www.samoapalene.ws.

Sāmoa Government. (2016). Constitution Amendment Bill No.2. Accessed from http: //www.samoagovt.ws.

Sanga, K. (2004). Making Philosophical Sense of Indigenous Pacific Research. Research the Pacific and Indigenous Peoples. T. Baba, O. Mahina, N. Williams and U. Nabobo-Baba (Eds). Centre for Pacific Studies. The University of Auckland. New Zealand, p. 41-52.

Sāuni, S. L. (2011). Samoan research methodology: The 'Ula - A New Paradigm. Pacific Asia Education 23(2), p. 53-64.

Schoeffel, P. (1995). The Samoan Concept of Feagaiga and its Transformation. In J. Huntsman (Ed.), Tonga and Sāmoa: images of gender and polity (pp. 85-109). Christchurch, N.Z.: Macmillan Brown Centre for Pacific Studies.

Schultz, E. (2008). Alagā' 'upu Fa'asāmoa: Samoan Proverbial Expressions. Pasifika Press. Auckland. New Zealand.

Shohamy, E. G. (2005). Language policy : hidden agendas and new approaches. Routledge. New York.

Siegel, J. (1992). Language Change and Cultural Change among Fiji Indians. Culture Change, Language Change: Case Studies from Melanesia. T. Dutton (Eds). Department of Linguistics, Research School of Pacific Studies. Australian National University. Canberra, p. 91-113.

Silipa, S. (2004). Fanaafi 'o Fa'amalama: A light within the light: nurturing coolness and dignity in Samoan students' secondary school learning in Aotearoa/NZ. Unpublished dissertation. Department of Education, University of Canterbury. 
Simanu, A. M. (2002). 'O si manu a ali 'i. Hawai'i, University of Hawai'i Press, Pasifika Press.

Smith, L. T. (2012). Decolonizing Methodologies : Research and Indigenous Peoples. London: London: Zed Books.

So‘o, A. (2008). Democracy and Custom: An Uneasy Alliance. Suva, Fiji: IPS Publications, University of the South Pacific.

So‘o, A. (2012). Political Development: Samoa's Parliamentary Journey from 1962-2012. Victoria Universty Press. Wellington, N.Z.

Spolsky, B. (1988). Report on the Samoan language in the New Zealand educational context / by Bernard Spolsky. In E. New Zealand. Department of (Ed.). Wellington, N.Z.: Wellington, N.Z. : B. Spolsky.

Spolsky, B. (2003). Religion as a Site of Language Contact. Annual Review of Applied Linguistics. McGroarty and Mary. United States of America, Cambridge University Press. 23, p. 81-94.

Spolsky, B. (2003). Religion as a Site of Language Contact. In McGroarty \& Mary. (Eds.), Annual Review of Applied Linguistics (Vol. 23, pp. 81-94). United States of America: Cambridge University Press.

Spolsky, B. (2004). Language policy. Cambridge

Spolsky, B. (2012). Family language policy - the critical domain. Journal of Multilingual and Multicultural Development 33(1), p. 3-11.

Starks, D. (2006). The Changing Roles of Language and Identity in the New Zealand Niuean Community: Findings from the Pasifika Languages of Manukau Project. International Journal of Bilingual Education and Bilingualism 9(3), p. 374-391.

Starks, D. (2006). The Changing Roles of Language and Identity in the New Zealand Niuean Community: Findings from the Pasifika Languages of Manukau Project. International Journal of Bilingual Education and Bilingualism, 9(3), 374-391.

Stohlberg, D. (2015). German in the Pacific: Language Policy In D. Schmidt-Bruken, S. Schuster, T. Stolz, I. Warnke, \& M. Wienberg (Eds.), Koloniallinguistic. Sprache in kolonialen Kontexten (pp. 317-362). Berlin: De Gruyter. 
Stolberg, D. (2013). German in Sāmoa: Historical Traces of a Colonial Variety. Poznan Studies in Contemporary Linguistics 49(3), p. 321-355.

Stubbs, M. (1996). Text and Corpus Analysis. Blackwell Publishers Ltd. Massachusetts.

Suaali'i-Sāuni, T. (2014). Prioritising the Vā in value and evaluation: an Aotearoa Pasifika perspective. Seminar presented at Aotearoa New Zealand Evaluation Association (ANZEA).

Suaali'i-Sāuni, T. and S. M. Fulu-Aiolupotea (2014). Decolonising Pacific research, building Pacific research communities and developing Pacific research tools: The case of the talanoa and the fa'afaletui in Sāmoa. Asia Pacific Viewpoint 55(3), p. 331-344.

Suaali‘i-Sāuni, T. M., Wendt, M. A., Mo‘a, V., Fuamatu, N., Vā‘ai, U. L., Whaitiri, R., \& Filipo, S. L. (2014). Whispers and vanities : Samoan indigenous knowledge and religion / edited by Tamasailau M. Suaali'i-Sauni, Maualaivao Albert Wendt, Vitolia Mo‘a, Naomi Fuamatu, 'Upolu Luma Vā'ai, Reina Whaitiri, Stephen L. Filipo: Huia Publishers. Wellington.

Sunia, F. (2014). Timata le gagana, CreateSpace Independent Publishing Platform.

Tamasese, K., et al. (2005). 'O le Taeao Afua, the new morning: a qualitative investigation into Samaon perspectives on mental health and culturally appropriate services. Australian and New Zealand Journal of Psychiatry 39, p. 300-309.

Tamasese, Tui Atua Tupua Tamasese Tā'isi Tupuola 'Efi. (1994). The Riddle in Samoan History: The Relevance of Language, Names, Honorifics, Genealogy, Ritual and Chant to Historical Analysis. The Journal of Pacific History, 29(1), 66-79.

Tamasese, Tui Atua Tupua Tamasese Tā'isi Tupuola 'Efi. (2003). In Search of Meaning, Nuance and Mataphor in Social Policy. Social Policy Journal of New Zealand, 20, 49-63.

Tamasese, Tui Atua Tupua Tamasese Tā‘isi Tupuola 'Efi. (2005). Clutter in Indigenous Knowledge, Research and History: A Samoan perspective. Social Policy Journal of New Zealand(25), 61-69.

Tamasese, Tui Atua Tupua Tamasese Tā'isi Tupuola 'Efi. (2005). Clutter in Indigenous Knowledge, Research and History: A Samoan perspective. Social Policy Journal of New Zealand(25), p. 61-69. 
Tamasese, Tui Atua Tupua Tamasese Tā'isi Tupuola 'Efi. (2008). Su 'esu'e manogi: In search of fragrance. Edited and compiled by Tamasa'ilau M. Suaali 'i-Sāuni, et al. Centre for Samoan Studies, National University of Sāmoa. Sāmoa.

Tamasese, Tui Atua Tupua Tamasese Tā'isi Tupuola 'Efi. (2008a). In Search of Harmony: Peace in the Samoan Indigenous Religion. In T. Suaali'i-Sāuni (Ed.), Su'esu'e Manogi: In search of fragance. Samoa: Centre for Samoan Studies, National University of Samoa.

Tamasese, Tui Atua Tupua Tamasese Tā'isi Tupuola 'Efi. (2009). Tau mai na 'o le pua 'ula Samoan fragrances in Samoan Thought. Pacific Thought Symposium. MAU Forum, Waitakere City Council Chambers, p. 1-11.

Tamasese, Tui Atua Tupua Tamasese Tā'isi Tupuola 'Efi. (2011). E lē 'o se timu na tō, 'o le ua e afua mai Manu'a: A message of love from fanauga. Paper presented at the Keynote Address, Professor James Ritchie Memorial Lecture Series, University of Waikato, Hamilton, New Zealand.

Tamasese, Tui Atua Tupua Tamasese Tā'isi Tupuola 'Efi. (2011). Sufiga 'o le Tuā'oi: Negotiating Boundaries. Public Address to University of Utah and Utah Community. Utah, September 2011.

Tamasese, Tui Atua Tupua Tamasese Tā'isi Tupuola 'Efi. (2013). Samoan Language and Culture. American Sāmoa, p. 1-9.

Tanielu, L. I. (1968). A Study of the Ministry of the Congregational Christian Church in Samoa and the Influence of Social Organisation, Traditions and Custom. Suva.

Taua'ā, A. (2005). Fa'asinomaga ma Fa'atinoga 'o Measina a Sāmoa. MA Iunivesite 'o le Amosā 'o Sāvavau. Apia, Sāmoa.

Tau'ili'ili, P. (1997). The art of Samoan siapo. University of Hawai'i,

Taule'ale'ausumai, F. J. (1994). The Samoan face of God. Victoria University of Wellington.

Tcherkèzoff, S. (2000). Are the Matai 'out of time'? tradition and democracy: contremporary ambiguities and historical transformations of the concept of chief. Pulega i Sāmoa. E. Huffer and A. So'o (Eds). Asia Pacific Press at the Australian National University and Institute of Pacific Studies, University of the South Pacific. Canberra, p.113-132. 
Tcherkézoff, S. (2008). First contacts in Polynesia: the Samoan case (1722-1848): Western misunderstandings about sexuality and divinity. ANU E Press. Canberra.

Tcherkezoff, S. and F. Douaire-Marsaudon, Eds. (2005). The Changing South Pacific: Identities and Transformations. ANU Press. Canberra.

Teaiwa, T. K. (2009). For or Before and Asia-Pacific Studies Agenda? Specifying Pacific Studies. Remaking Area Studies. Wesley-Smith (Eds), Teaching and Learning Across Asia and the Pacific. University of Hawai 'i Press. Honolulu. Hawai‘i, p. 110-124.

Territories, N. Z. D. I. (1951). Report by the New Zealand government to the General Assembly of the United Nations on the administration of Western Samoan for the calendar year 1960. Govt. Printer, Wellington. New Zealand.

Thaman, K. H. (1988). Ako and faiako: Educational concepts, cultural values, and teacher role perceptions, Unpublished $\mathrm{PhD}$ thesis. University of the South Pacific.

Thaman, K. H. (1993). Kakala. Mana Publications. Suva.

Thomas, R. M. (1984). American Sāmoa and Western Sāmoa. Pergamon Press. New York.

Thomason, S. (2010). Contact Explanations in Linguistics. In R. Hickey (Ed.), The Handbook of Language Contact (pp. 31-47): Blackwell Publishing Ltd.

Tiatia, J. (1998). Caught between cultures: a New Zealand-born Pacific Island perspective. Christian Research Association. Auckland.

Tom, N. Y. W. (1986). The Chinese in Sāmoa: 1875-1985. Western Sāmoa: Western Samoa Historical and Cultural Trust.

Tomkins, S. M. (1992). The Influenza Epidemic of 1918-19 in Western Sāmoa. The Journal of Pacific History 27(2), p. 181-197.

Topping, D. (1987). Literacy in the Pacific Islands. Interchange 18(1/2), p. 48-59.

Trudgill, P. (1986). Dialects in Contact. Oxford: Blackwell.

Tsukamoto, A. (1988). The Language of Niuafo 'ou Island, Australian National University.

Tuagalu, I. (2008). Heuristics of the Vā. AlterNative: An Indigenous Journal of Indigenous Peoples. Vol 4(1), p. 107-126. 
Tu'i, T. (1987). Lāuga: Samoan Oratory. Institute of Pacific Studies and the Western Sāmoa Extension Centre of the University of the South Pacific and the National University of Sāmoa. Suva.

Tualaulelei, E. (2008). Indications Of Language Shift From A Public Face Of A Samoan Speech Community. New Zealand Studies in Applied Linguistics, 14(1), 53-70.

Tuhiwai-Smith, L. (1999). Decolonizing Methodologies. Dunedin: University of Otago Press. Tuhiwai-Smith, L. (2008). On Tricky Ground: Researching the Native in the Age of Uncertainty. The Sage Handbook of Qualitative Research. Thousand Oaks, California, Sage Publications, p. 85-107.

Tuimaleali'ifano, M. A. (2006). 'O Tama 'Aiga: the politics of succession to Samoa's paramount titles. University of the South Pacific, Institute of Pacific Studies.

Tuimaualuga, L. (1977). The Ministry of the Congregational Christian Church in Samoa in a Fa'asamoa (Samoan Custom) Framework. Pacific Theological College, Suva.

Tunufa'i, L. (2016). Pacific Research: Rethinking the Talanoa Methodology. New Zealand Sociology 31(7), p. 227-239.

Tupuola, A. M. (2004). Pasifika edgewalkers: complicating the achieved identity status in youth research. Journal of Intercultural Studies 25(1), p. 87-100.

Turner, G. (1861). Nineteen Years in Polynesia: Missionary Life, Travels, and Researches in the Islands of the Pacific. London: John Snow, Paternoster Row.

Turner, G. (1984). Sämoa: A Hundred Years Ago and Long Before. University of the South Pacific, Institute of Pacific Studies.

UNESCO (1978). The Recording of Polynesian Oral Traditions. A Report on the UNESCO Workshop.

Utumapu, T. (1998). O le poutu: Women's roles and Samoan language nests. In S. McNaughton (Ed.): ProQuest Dissertations Publishing.

Vā‘ai, S. (1999). Sāmoa Fa 'amatai and the rule of law. National University of Sāmoa. Sāmoa. Vaioleti, T. (2006). Talanoa Research Methodology: A Developing position on Pacific Research. Waikato Journal of Education 12, p. 21-34. 
Van Manen, M. (1990). Researching lived experience : human science for an action sensitive pedagogy State University of New York Press. Albany, New York.

Vito, M. I. V. F. (2011). Fa'afa'aipoipoga o le fa'akerisiano ma le aganu'u fa'asāmoa Auckland, N.Z.: Inkprint Ltd.

Wahlroos, S. (2002). Mã'ohi Heritage Press. Honolulu, Hawai'i.

Walker, D. (2019). What is Indigeneity. Te Kaharoa, 12, 1-12.

Weinreich, U. (1964). Languages in Contact. London: Mouton \& Co.

Weinreich, U., Labov, W., \& Herzog, M. I. (1968). Empirical Foundations for a Theory of Language Change. In Lehmann, W. P., Malkiel, \& Yakov. (Eds.), Directions for Historical Linguistics (pp. 97-195). Austin \& London: University of Texas Press.

Weisler, M. I. (1998). Hard Evidence for Prehistoric Interaction in Polynesia. Current Anthropology, 39(4), 521-532.

Wendt, A. (1970). Towards a New Oceania. Mana Review, 1(1), p. 49-60.

Wendt, A. (1987). Novelists and Historians and the Art of Remembering. Class and culture in the South Pacific, A. Hooper (Eds). Centre for Pacific Studies, University of Auckland. Institute of Pacific Studies, University of the South Pacific, p. 78-91.

Wesley-Smith, T. (1995). Re-thinking Pacific Islands Studies. Pacific Studies, 18(2).

Williamson, R. W. (1967). The social and political systems of central Polynesia. Oosterhout, Anthropological Publications.

Wilson, S. (2010). Le Tofi Ne 'i Vale Tu'ulima: Perceptions of Samoan Students, Teachers and Parents on the Place of the Samoan Language in New Zealand Today. (Master of Arts), Victoria University of Wellington.

Wilson, S. (2017). A malu ' $i$ fale le gagana, e malu fo' $i$ ' $i$ fafo. The Use and Value of the Samoan Language in Samoan Families in New Zealand. Auckland University of Technology. Winford, \& Donald. (2003). Contact-Induced Changes-Classification and Processes. OSUWPL, 57, 129-150. 
APPENDIX ONE: Ethics Approval

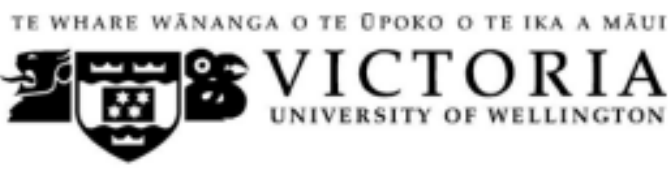

MEMORANDUM

Phone $\quad 0-4-4635480$

Email susan.corbettovuw.ac.nz

\begin{tabular}{|c|c|}
\hline TO & Sadat Muaiava \\
\hline COPY TO & Dr John Macalister \\
\hline FROM & AProf Susan Corbett, Convener, Human Ethics Committee \\
\hline DATE & 7 September 2017 \\
\hline PAGES & 1 \\
\hline SUBJECT & $\begin{array}{l}\text { Ethics Approval: } \mathbf{2 5 2 3 7} \\
\text { A corpus-based examination of Samoan language change (1906- } \\
2014 \text { ) }\end{array}$ \\
\hline
\end{tabular}

Thank you for your application for ethical approval, which has now been considered by the Standing Committee of the Human Ethics Committee.

Your application has been approved from the above date and this approval continues until 31 March 2018. If your data collection is not completed by this date you should apply to the Human Ethics Committee for an extension to this approval.

Best wishes with the research.

Kind regards

Susan Corbett

Convener, Victoria University Human Ethics Committee 


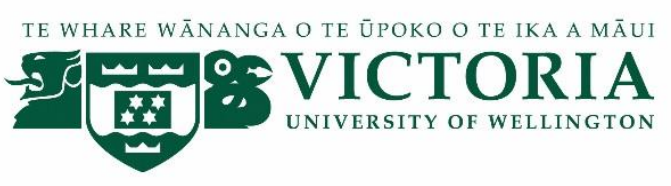

\section{A Corpus-Based Examination of Samoan Language Change (1906-2014)}

\section{INFORMATION SHEET FOR PARTICIPANTS}

Thank you for your interest in this project. Please read this information before deciding whether or not to take part. If you decide to participate, thank you. If you decide not to take part, thank you for considering my request.

\section{Who am I?}

My name is Sadat Muaiava and I am a Doctoral student in the Va'aomanū Pasifika unit at Victoria University of Wellington. This research project is work towards my dissertation.

\section{What is the aim of the project?}

This project is a diachronic text-based examination of the Samoan language from 1906-2014. The texts are sources from the Sāvali and Sulu Sāmoa newspapers. This research has been approved by the Victoria University of Wellington Human Ethics Committee.

\section{How can you help?}

If you agree to take part I will interview you at a place of your choice. I will ask you questions about the Samoan language/ language change. The interview will take no longer than 30 minutes. I will audio record the interview with your permission and write it up later. You can choose to not answer any question or stop the interview at any time, without giving a reason. You can withdraw from the study by contacting me at any time before the end of October 2018. If you withdraw, the information you provided will be destroyed or returned to you.

\section{What will happen to the information you give?}


This research is confidential. This means that the researchers named below will be aware of your identity but the research data will be combined and your identity will not be revealed in any reports, presentations, or public documentation.

Only my supervisors and I will read the notes or transcript of the interview. The interview transcripts, summaries and any recordings will be kept securely and destroyed on March 2019.

\section{What will the project produce?}

The information from my research will be used in my $\mathrm{PhD}$ dissertation.

\section{If you accept this invitation, what are your rights as a research participant?}

You do not have to accept this invitation if you don't want to. If you do decide to participate, you have the right to:

- choose not to answer any question;

- $\quad$ ask for the recorder to be turned off at any time during the interview;

- $\quad$ withdraw from the study before the end of October 2018;

- $\quad$ ask any questions about the study at any time;

- receive a copy of your interview recording;

- $\quad$ receive a copy of your interview transcript;

- $\quad$ read over and comment on a written summary of your interview;

- be able to read any reports of this research by emailing the researcher to request a copy.

\section{If you have any questions or problems, who can you contact?}

If you have any questions, either now or in the future, please feel free to contact:

\section{Student:}

Name: Sadat Muaiava

University email address:

Sadat.Muaiava@vuw.ac.nz

\section{Supervisor:}

Name: Associate Professor John Macalister

Role: Primary supervisor

School: School of Linguistics and Applied

Language Studies

Phone: (04) 4635609

Email: John.Macalister@vuw.ac.nz 


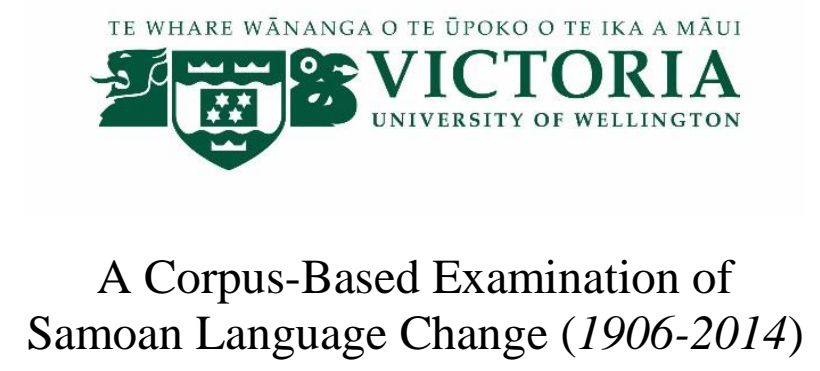

\section{CONSENT TO INTERVIEW}

This consent form will be held for 2 years.

Researcher: Sadat Muaiava, Va'aomanū Pasifika, Victoria University of Wellington.

- I have read the Information Sheet and the project has been explained to me. My questions have been answered to my satisfaction. I understand that I can ask further questions at any time.

- I agree to take part in an audio recorded interview.

\section{I understand that:}

- I may withdraw from this study at any point before end of October 2017, and any information that I have provided will be returned to me or destroyed.

- $\quad$ The identifiable information I have provided will be destroyed on by March 2018

- Any information I provide will be kept confidential to the researcher and the supervisor.

- I understand that the results will be used for a $\mathrm{PhD}$ dissertation to Victoria University of Wellington

- I consent to information or opinions which I have given being attributed to [me/my organisation] in any reports on this research and have the authority to $\quad$ Yes $\square$ No agree to this on behalf of the organisation:

- I would like a copy of the recording of my interview:

Yes $\square \quad$ No 
- I would like a copy of the transcript of my interview:

- I would like a summary of my interview:

- I would like to receive a copy of the final report and have added my email address below.
Yes $\square \quad$ No

Yes $\square \quad$ No

Yes $\square \quad$ No

Signature of participant:

Name of participant:

Date:

Contact details: 


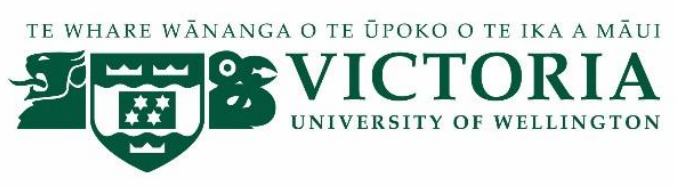

\title{
A Corpus-Based Examination of Samoan Language Change (1906-2014)
}

\author{
$\underline{\text { Fa'afaletui Questions }}$
}

\section{Fa`afeiloa`i (Greetings)}

1. In what capacity are you involved with in regards to the Samoan language?

2. What interests you about the Samoan language?

3. What are your thoughts in regards to the state of the Samoan language today?

4. To what extent do you think the Samoan language has changed?

- Have these changes been positive or negative for the Samoan language?

5. Is spoken and written Samoan the same or different? How?

6. What are your thoughts about the influences of religious (Bible/church) language is having on the Samoan language?

7. To what extent has the introduction of Western forms of governance had and continue to have on the Samoan language?

8. With many Samoans now living in metropolitan centres such as Auckland, Hawai `i, Sydney, and mainland America, what influences do you think the diasporic Samoan community is having on the Samoan language?

Fa`afetai tele lava

(Thank you very much) 
APPENDIX FIVE: Glossary

\begin{tabular}{|c|c|}
\hline ‘àiga & family \\
\hline 'aufaigaluega & pastors \\
\hline 'ava 'o le feiloa'iga & welcome ceremony \\
\hline 'ekālesia & congregation/denomination \\
\hline 'Ekālesia 'o le 'Au Pa'ia e Gata Ai & Mormon church \\
\hline ie toga & fine mat \\
\hline 'Igilisi & English \\
\hline 'ири nonō & borrowed words \\
\hline afiafi & evening worship \\
\hline aganu'u & Samoan culture \\
\hline 'Akelikana & Anglican \\
\hline 'Akiepikopō & Archbishop \\
\hline alagà'upu & metaphorical expression \\
\hline Ali $^{\prime} i$ & Christian deity \\
\hline ali $i$ & high chief \\
\hline ali $i$ sili & head of native administration \\
\hline ali 'i tōfia & government official \\
\hline alofa & love \\
\hline Ametimane & German official \\
\hline Ao 'o le Mālō & Head of State \\
\hline 'Ekālesia Fa'alapotopotoga Kerisiano Sāmoa & Congregational Christian Church Sāmoa \\
\hline Fa'afaletui & Samoan research methodology \\
\hline fa'afeagaiga & covenanted pastor \\
\hline iloga o le & diacritical marks \\
\hline
\end{tabular}




\begin{tabular}{|c|c|}
\hline fa'aipoipoga & wedding \\
\hline fa'alupega & honorifics \\
\hline fa'amamafa & macron \\
\hline \multirow[t]{2}{*}{ fa'amanatuga } & holy communion (Congregational \\
\hline & denomination) \\
\hline fa'amasinoga & court of law \\
\hline fa'amatai & Samoan chiefly system \\
\hline fa' asāmoa & Samoan culture \\
\hline fa'asinomaga & a person's designation (e.g. village) \\
\hline fa'atonu & director \\
\hline fa'atūlima & greetings \\
\hline fa'aulufalega & church inauguration \\
\hline faiā'oga & teacher \\
\hline faiavā & in-law (male) \\
\hline faife'au & pastor \\
\hline failauga & lay preacher (Methodist denomination) \\
\hline failautusi & secretary \\
\hline faipese & choir master \\
\hline faipule & district mayor \\
\hline fale 'o aualuma & council of high chief and orators \\
\hline & daughters \\
\hline fale 'o taulele' $a$ & council of untitled males \\
\hline fale tapua' $i$ & church building \\
\hline falefaigaluega & workplace \\
\hline falesā & church building \\
\hline
\end{tabular}


faletua

feagaiga

finagalo

fofoga fetalai

folasaga

gagana

gagana fa'aaloalo

gagana fa'alogo

gagana fa 'amatai

gagana ta'atele

gagana tautala

gagana tusitusi

Iesu

Igoa

Kaisa

Kaisalika

Kaisalina

kalama

Katoliko

koma liliu

komisi

konesane

kovana

kovana sili wife of a pastor/chief

brother's eldest sister

chief's will/thought

speaker of the house

introduction

language

respectful language

phonology

chiefly language

everyday language

spoken language

written language

Jesus

name

German Kaiser

Imperial (German word Kaiserlich)

empress (German word Kaiserin)

grammar

Catholic

glottal stop

commission

consonant

governor

governor/president 
lagi

lagona fa 'amaualalo

lau

lāuga 'o le fa 'aipoipoga

lāuga 'o le fa'aulufalega

lāuga 'o le ifoga

lāuga 'o le saofa' $i$

lāuga 'o le ta'alolo

lāuga 'o le umusaga

lāuga a le faife 'au

lāuga fa'afetai

lāuga fa' 'alelotu

lāuga fa 'amatai

lāuga usu

$L M S$

losalio

lotu

lotu afiafi

Lotu Patipati

Lotu Pope

Lotu Ta 'iti

Lotu Toga

malelega

maliu heaven

humble

strand of knowledge

wedding speech

church inauguration speech

reconciliation speech

title investiture speech

food presentation speech

house inauguration speech

pastor's speech/sermon

thank you speech

sermon

chiefly speech

hosts speech

London Missionary Society

rosary

Christian worship

evening worship

Pentecostal denomination

Catholic denomination

Congregational denomination

Methodist denomination

speech of a paramount chief

funeral 
$m \bar{a} l \bar{o}$

Màlō Aufa 'atasi

malumalu

mana

matāgaluega (church)

matāgaluega (govt)

matai

matua

matūpalapala

mau

Metotisi

minisitā

misiona

misionare

muāgagana

nofotane

$n u ' u$

nunuavaga

osigā feagaiga

pa ia

palemene

palemia

papakema

Papālagi
Westminster government

Commonwealth

church building

supernatural power

regional church district

government division/ministry

chief/orator

sermon message

honourable bestowment

document

Methodist

cabinet minister

mission

missionary

metaphorical expression

in-law (female)

village

pre-Western word for wedding

religious ritual of initiation

honorific given to chiefs

parliament

prime minister

baptism in Catholic church

European 
papatisoga

Pātele

pese

poto

pulega

pulela'a

pulenu' $u$

sāpati

saunoaga

Sāvali

Sea

Siāmani

soga 'imiti

Sui 'o le Fono 'o Sui Tōfia

Sui va'aia 'o le Atua

Sulu Sāmoa

ta'alolo

Tagaloaalagi

tagata mātutua

Talalelei

Tamā

tanoa

tapu

tapua $i$ baptism in Congregational church

Catholic Father

hymn

knowledge

local church district

pulpit

village mayor

sabbath

speech of a chief

government newspaper

Methodist Elder pastor

Germany

male cultural tattoo

Council of Deputies

pastors

church newspaper

food presentation

Samoa's pre-Christian deity

elders

Good Word (Christianity)

Heavenly Father

speech of a chief

tabboo/forbidden

to worship 


\begin{tabular}{|c|c|}
\hline tapuā'iga & church service \\
\hline tatau & male cultural tattoo \\
\hline tausi & wife of an orator \\
\hline tausi matāgaluega & lay preacher (Methodist denomination) \\
\hline tautala leaga & informal register (k-style) \\
\hline tautala lelei & formal register (t-style) \\
\hline tautalaga & every day word for speech \\
\hline tautua & service \\
\hline ti'ākono (Catholic) & Catholic priest \\
\hline ti'ākono (Congregational) & Congregational deacon \\
\hline tini & pre-Christian wedding chants \\
\hline Toeā 'ina & Congregational Elder pastor \\
\hline tofi & inheritance \\
\hline tu'umālō & death of a high chief \\
\hline tūlāfale & orator \\
\hline tūlāfale-ali ${ }^{i} i$ & orator-chief \\
\hline Tusi 'o le Ola & Bible \\
\hline Tusi Pa 'ia & Bible \\
\hline Tusi Pese & hymn book \\
\hline Tusi Sā & Bible \\
\hline Tusigāigoa & church fundraising event \\
\hline tūto 'atasi & political independence \\
\hline usufono & meeting delegates \\
\hline vaueli & vowel \\
\hline
\end{tabular}


praise 